OCCASIONAL PAPER

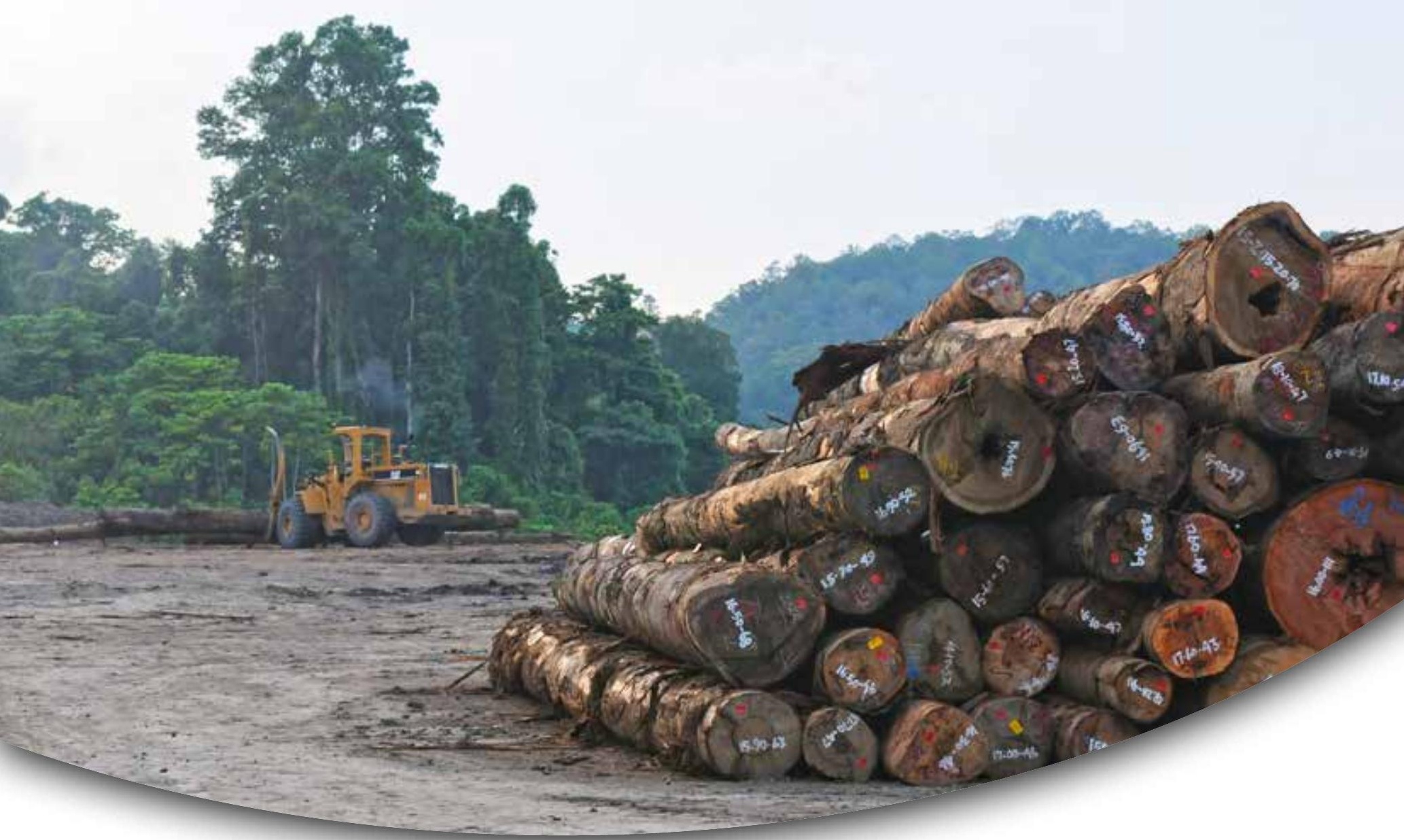

\title{
The context of natural forest management and FSC certification in Indonesia
}

Edited by

Claudia Romero

Francis E Putz

Manuel R Guariguata

Erin O Sills

Ahmad Maryudi

Ruslandi

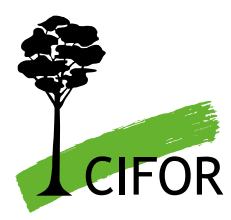





\section{The context of natural forest management and FSC certification in Indonesia}

Edited by

Claudia Romero

Department of Biology, University of Florida

Center for International Forestry Research (CIFOR)

Francis E Putz

Department of Biology, University of Florida

Center for International Forestry Research (CIFOR)

Manuel R Guariguata

Center for International Forestry Research (CIFOR)

Erin O Sills

Department of Forestry, North Carolina State University

Center for International Forestry Research (CIFOR)

Ahmad Maryudi

Gadjah Mada University

Ruslandi

Department of Biology, University of Florida 
Occasional Paper 126

(c) 2015 Center for International Forestry Research

(c) (1) Content in this publication is licensed under a Creative Commons Attribution 4.0 International (CC BY 4.0), http://creativecommons.org/licenses/by/4.0/

ISBN 978-602-387-002-8

DOI: $10.17528 /$ cifor/005653

Romero C, Putz FE, Guariguata MR, Sills EO, Maryudi A and Ruslandi. 2015, eds. The context of natural forest management and FSC certification in Indonesia. Occasional Paper 126. Bogor, Indonesia: CIFOR.

Photo by Mokhammad Edliadi/CIFOR

\author{
CIFOR \\ Jl. CIFOR, Situ Gede \\ Bogor Barat 16115 \\ Indonesia \\ $\mathrm{T}+62(251) 8622-622$ \\ $F+62(251) 8622-100$ \\ E cifor@cgiar.org
}

\title{
cifor.org
}

We would like to thank all donors who supported this research through their contributions to the CGIAR Fund. For a list of Fund donors please see: https://www.cgiarfund.org/FundDonors

Any views expressed in this publication are those of the authors. They do not necessarily represent the views of CIFOR, the editors, the authors' institutions, the financial sponsors or the reviewers. 


\section{Contents}

Acknowledgments $\quad$ viii

$\begin{array}{ll}\text { Executive summary } & \text { ix }\end{array}$

1 Impact evaluation background of FSC certification of natural forests: The case of Indonesia

Claudia Romero, Francis E Putz, Erin O Sills, Manuel R Guariguata, Paolo O Cerutti and Guillaume Lescuyer

2 The political economy of forest land-use, the timber sector, and forest certification Ahmad Maryudi

3 Typology of natural Forest Management Units (FMUs) in Kalimantan Ruslandi and Claudia Romero

4 Dynamics along the Natural Forest Certification Continuum Ruslandi

5 Assessment of drivers of self-selection into natural forest management certification Ruslandi

6 Conclusions

Claudia Romero, Francis E Putz, Erin O Sills, Manuel R Guariguata,

Paolo O Cerutti and Guillaume Lescuyer 


\section{List of figures, tables and boxes}

\section{Figures}

1.1 Integration of studies that generate information (Phase I).

1.2 Schematic representation of key steps and decisions related with FSC certification process.

1.3 Operational model of the process throughout the different stages of FSC evaluation. 4

2.1 Timeline of land use planning and allocation regulations in Indonesia. 13

2.2 General forest land-use categories and transitions in Indonesia over the last years. $\quad 14$

2.3 Trends in total area of natural forest vs. timber plantation concessions. 21

$\begin{array}{ll}3.1 \text { Results of a MFA on groups of variables. } & 38\end{array}$

3.2 Hierarchical tree showing the relationships among FMUs. 40

3.3 Results of a hierarchical clustering on the resulting scores of a MFA for FMUs. $\quad 40$

4.1 Certification continuum depicted as a stylized series of states superimposed. $\quad 56$

4.2 Transitions (numbered arrows) between stages along the certification. 58

4.3 Number of active (green), new (yellow), and expired (red) FMUs. 61

$\begin{array}{ll}4.4 & \text { Cumulative number of newly created FMUs. }\end{array} 62$

4.5 Proportion of active operating FMUs. 63

4.6 Number of natural forest FMUs in Indonesia in the considering certification stage. $\quad 64$

$\begin{array}{ll}4.7 & \text { Number of FMUs in the en route to certification stage. } \\ 4.8 & 68\end{array}$

$\begin{array}{ll}4.8 \text { Number of newly certified FMUs. } & 69\end{array}$

4.9 Area of newly certified FMUs.

$\begin{array}{ll}4.10 \text { Number of FMUs operating in natural forest management. } & 73\end{array}$

4.11 Number of certified FMUs. $\quad 72$

4.12 Dynamics of FMUs along the certification continuum and potential links. $\quad 74$

5.1 Drivers of natural forest certification mentioned by stakeholders. 83

5.2 Dominant motivation for natural forest certification mentioned by stakeholders. $\quad 84$

\section{Tables}

2.1 Indonesia's forest classes based on TGHK and Padu Serasi. 11

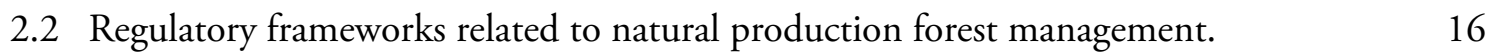

2.3 Total concession area of Indonesia's 15 largest timber groups in $1990 . \quad 18$

2.4 Required payments into the Reforestation Fund (DR). 20

2.5 Extent of FSC and LEI certification in Indonesia. 26

3.1 Description of categorical variables used to construct a typology of active FMUs. 38

3.2 Correlations between groups of variables and each of the two dimensions of the MFA. 39

3.3 Contribution, quality of representation, and test statistics. 39

4.1 Rules for assigning FMUs to different stages. 59

4.2 Results of likelihood ratio test for linked annual certification decisions that moved FMUs engaged in natural forest management. 66

4.3 Results of likelihood ratio tests for linked annual certification decisions on the certification trajectory (1996-2013). 66

4.4 Results of likelihood ratio tests for linked annual certification decisions
leading to the certified stage (1996-2013). 


\title{
List of acronyms
}

\author{
APHI Asosiasi Pengusaha Hutan Indonesia (The Indonesian forest concessionaires association) \\ Apkindo Asosiasi Panel Kayu Indonesia (The Indonesian Wood Panel Producers Association) \\ Bakosurtanal Badan Koordinasi Survei dan Pemetaan Nasional (National Coordination Agency on \\ Survey and Mapping) \\ BAL Basic Agrarian Law \\ Bapennas Badan Perencanaan Pembangunan Nasonal (National Development Planning Board) \\ BFL Basic Forestry Law \\ BFMP Berau Forest Management Project (European Union funded project) \\ CB Certification body \\ CITES Convention on International Trade in Endangered Species of Wild Fauna and Flora \\ CU Control Union \\ DBH Diameter at Breast Height \\ DJR Dana Jaminan Reboisasi (Reforestation Deposit Fund) \\ DR Dana Reboisasi (Reforestation Fund) \\ EU European Union \\ FD Forestry Directorate \\ FLEGT Forest Law Enforcement, Governance and Trade \\ FMU Forest management unit \\ FSC Forest Stewardship Council \\ GoI Government of Indonesia \\ GR Government Regulation \\ HCVF High conservation value forest \\ HGU Hak Guna Usaha (Land Cultivation Rights) \\ HL Hutan Lindung (Protection Forest) \\ HP Hutan Produksi Tetap (Permanent Production Forest) \\ HPT Hutan Produksi Terbatas (Limited Production Forest) \\ HPK Hutan Produksi Konversi (Convertible Production Forest) \\ HTI Hutan Tanaman Industri (Industrial tree plantations) \\ IFCC Indonesian Forestry Certification Cooperation \\ IFM Improved forest management \\ IHH Iuran Hasil Hutan (Timber Royalties) \\ IMF International Monetary Fund
}


IPHH

ITFMP

JCP

KAN

KSKI

LEI

MoA

$\mathrm{MoF}$

NRMP

OSC

PEFC

PHPL

RA

RIL

RTRW

RTRWP

SA

SCKPFP

SCS

SFM

SFMP

SGS

SILIN

STREK

SUA

SVLK

TBI

TFF

TFT

TGHK

TLAS

TNC

TPI

TPTI

VB

VPA

WB

WWF
Iuran Hak Pengusahaan Hutan (Forest Concession Fee)

Indonesia-UK Tropical Forest Management Programme

Joint Certification Protocol of LEI-FSC

Komite Akreditasi Nasional (National Accreditation Body)

Kerjasama Sertifikasi Kehutanan Indonesia (Indonesian Forestry Certification Cooperation)

Lembaga Ekolabel Indonesia (The Indonesian Ecolabeling Institute)

Ministry of Agriculture of Republic of Indonesia

Ministry of Forestry of Republic of Indonesia

Natural Resource Management Project (USAID funded project)

Operations and occupational, safety, and health

Programme for the Endorsement of Forest Certification

Pengelolaan hutan produksi lestari (MoF mandatory forest certification on Sustainable Management of Production Forests)

Rainforest Alliance Smartwood

Reduced-impact-logging

Rencana Tata Ruang Wilayah (Spatial Land Use Planning)

Rencana Tata Ruang Wilayah Provinsi (Provincial Spatial Plan)

Soil Association Woodmark

South and Central Kalimantan Production Forest Project (European Union funded project)

Scientific Certification Systems

Sustainable forest management

Sustainable forest management project (Germany funded project)

Société Générale de Surveillance

Silvikultur Intensif (Intensive Silviculture)

Silvicultural techniques for the regeneration of logged over forests in East Kalimantan

Suaka Alam (Nature Reserves)

Sistem Verifikasi Legalitas Kayu (Indonesian timber legality assurance system)

The Borneo Initiative

Tropical Forest Foundation

The Forest Trust (formerly Tropical Forest Trust)

Tata Guna Hutan Kesepakatan (Consensus-Based Forest Land-use)

Timber Legality Assurance System

The Nature Conservancy

Tebang Pilih Indonesia (The Indonesian Selective Cutting System)

Tebang Pilih Tanam Indonesia (The Indonesian Selective Cutting and Replanting System)

Verification Body

Voluntary Partnership Agreements

World Bank

World Wildlife Fund for Nature 


\section{Acknowledgments}

The work presented in Chapters 2-5 derived in part from intensive discussions, guidance, and inputs from members of the principal research team C. Romero, F. E. Putz and E. O. Sills. Ruslandi would also like to express gratitude to all people and parties, particularly certification coaches, certification bodies, and managers of forest management units for sharing their knowledge and information on natural forest certification in Indonesia. A. Maryudi also wants to thank P. Gellert (The University of Tennessee) for his comments and insights.
All authors want to thank FSC, both international and regional offices, for facilitating information and patiently resolving queries regarding certification data.

This work was made possible through funding from the United States Agency for International Development (USAID) and from the Consultative Group for International Agricultural Research (CGIAR) Research Program on Forests, Trees and Agroforestry. Thanks are also due to PROFOR-World Bank for initial support, without which these ideas would have not developed. 


\section{Executive summary}

Management decisions on appropriate practices and policies regarding tropical forests often need to be made in spite of innumerable uncertainties and complexities. Among the uncertainties are the lack of formalization of lessons learned regarding the impacts of previous programs and projects. Beyond the challenges of generating the proper information on these impacts, there are other difficulties that relate with how to socialize the information and knowledge gained so that change is transformational and enduring. The main complexities lie in understanding the interactions of social-ecological systems at different scales and how they varied through time in response to policy and other processes.

This volume is part of a broad research effort to develop an independent evaluation of certification impacts with stakeholder input, which focuses on FSC certification of natural tropical forests ${ }^{1}$. Chapter 1 - Impact evaluation background of FSC certification of natural forests: the case of Indonesia contains information to help guide the design of evaluation research to answer the questions of when, where, how, to what extent, why, at what cost to whom, and for how long FSC certification has maintained the values of natural tropical forests. More specifically, the evaluation program aims at building the evidence base of the empirical biophysical, social, economic, and policy effects that FSC certification of natural forest has had in Indonesia as well as in other tropical countries. As such, it will generate impact information and socialize the knowledge gained on two linked fronts: 1) a theory-based impact evaluation of the intervention developed through counterfactual analysis, complemented with 2) a process evaluation, which assesses the extent to which this intervention was implemented as designed.

1 "Evaluation of the Impacts of Forest Stewardship Council (FSC) Certification of Natural Forest Management in the Tropics"
The results of four baseline studies are presented below. By publishing this information, we hope to solidify the learning and idea exchange platform established throughout the development of the studies, engage more people and institutions in our research in parallel efforts to evaluate and analyze certification, and in future discussions about the role of certification in forest conservation and its implications for local livelihoods.

\section{The first study [Chapter 2 - The political} economy of forest land-use, the timber sector, and forest certification] analyzes the political economy factors that underlie decisions regarding the use of forested lands. It finds that policies and processes of forestland allocation in Indonesia have been dominated by a strong development paradigm that emphasized large-scale exploitation of forest resources with further conversion of once-forested lands to other uses. The country's timber sector has been characterized by a strong affiliation of few individuals from the business sector loyal to forest power holders in the government. The business people enjoyed preferential forest policies that allowed them to secure and capture fantastic shortterm economic profits. Along with insufficient monitoring mechanisms, preferential policies encouraged concession holders to employ rampant and destructive logging operations. Policies that favored industrial plantations further facilitated rapid conversion of high biodiversity natural forests into monoculture timber or oil palm plantations.

International influences promoting improved forest practices in Indonesia succeeded only to a limited extent. This seems to also be the case of FSC natural forest certification, which is widely promoted to encourage responsible forest management through the appeals of market incentives. The progress of FSC certification in Indonesia has been shaped by a number of factors operating in different landscapes and at different scales, from management units to national levels. At the national level, despite concrete 
commitments by the government to promote the wise use of forests, many of its policies conflict with the goals of sustainable forestry. This bleak situation was not aided by the limited signals of economic benefits and some evidence for the high costs of certification processes and improved forest management.

Although there has been a steady rise in certification in Indonesia in recent years, key challenges remain. At the macro level, harmonization of policies coupled with institutional clarity and coordination are needed with regard to land-uses and their allocation. At the practical level of the forest management units, the intensification of management may prove to be a big threat to certification if it is shown to have large deleterious impacts on biodiversity and forest functions. The recent prevalence of legality verification mechanism represents an interesting dynamic in the forest sector. Legality verification may facilitate forest management certification as a transitional phase if managers realize that by establishing their legality, they are well on the way towards certification. However, if key markets for Indonesia timber products are satisfied with legality verification and do not push for management certification, then enthusiasm for certification may decline.

\section{The second study [Chapter 3 - Typology of} Natural Forest Management Units (FMUs) in kalimantan] explores the characteristics of 171 forest management units (FMUs) operating in Kalimantan and groups them on the basis of variables that influence adoption of certification as well as outcomes of forest management. Although FMUs in Indonesia are relatively homogenous in terms of forest ownership (e.g., there are no community-based FMUs in Kalimantan) and forest management systems employed, these units varied in other characteristics. Variables related to timber production capacity (e.g., area, percentage of limited production forest), likelihood of social conflicts (e.g., population density), management operation, and market strategies explain most of the variation among FMUs. Based on these variables, four groups (i.e., clusters) of FMUs with shared traits were identified: whether or not the FMU is vertically integrated with a processing facility; type of outlet for timber harvest; whether or not logging is subcontracted or carried out by employees of the FMU; \% limited production forest; and, within-FMU human population density. These groups provide a good basis to guide the selection of FMUs to be considered as members of the counterfactual group for the empirical evaluation of impacts.

The next study [Chapter 4 - Dynamics along the natural forest certification continuum] shows the intricacies of how FSC certification has proceeded in Indonesia. This research documented those decisions made by FMUs along the certification continuum and their dynamics over the period 1996-2013. It also linked decisions made during the critical junctures identified in the political economy analyses (e.g., changes in political regime and legal frameworks, market dynamics, onset of donor and other external social actors' programs) and proposed mechanisms through which these events might have shaped FMUs certification choices.

FMUs that engaged in certification (39) in Indonesia represent only $13.7 \%$ of the active logging operations in the country in 2013 (285 FMUs) and $-20 \%$ in terms of their area $(22,682,798 \mathrm{ha})$. Currently there are 14 FMUs FSC certified $(-1.7$ million ha; $-8 \%$ of the area in active logging operations).

The observed dynamics along the certification continuum varied over time and related to the general forces at work behind forestry business fluctuations. FMU choices seem to have been more affected by economic factors operating at both national and international levels than by political events. The pace at which FMUs moved along advanced stages into the continuum (e.g., considering certification, en route to certification, certified) accelerated sharply during the last three years of the studied time period. This behavior seems to be associated with an increase in availability of external funding for training and for other activities leading to adopt FSC certification.

The last study [Chapter 5 - Assessment of drivers of self-selection into natural forest management certification] explores the drivers and internal motivations of FMUs to seek FSC certification, based on the perspective of stakeholders directly involved with natural forest management certification in the country. Interviews were conducted with 34 respondents representing both 1) FMUs that are certified, en 
route to certification, considering certification, and never certified operations, and 2) other stakeholders involved with natural forest certification. In these interviews, the perceptions of external drivers and internal motivations for pursuing FSC certification were explored. The study revealed that the drivers of natural forest certification in Indonesia varied over time, although economic factors - including market incentives and financial support for certification - were perceived as dominant. Economic motivations, particularly increased market access and premium prices, were cited as the main drives to pursue certification. Yet, non-market economic motivations such as corporate image and government incentives were also cited as important especially during the early years of certification in Indonesia. Given that FMUs operating in the country are profit-oriented companies, these findings are not surprising but nevertheless raise the question of why other profitmaximizing companies did not pursue certification. In most FMUs, decisions related to certification are reportedly made by owners and heads of forest industry divisions. Marketing strategies and knowledge about certification differentiated the FMUs in relation to their certification decisions. For FMUs that chose to pursue certification, operational adjustments such as the need to hire new staff and staff capacity building were big challenges, as was the need to meet certificationspecific requirements such as HCVF establishment, social program development, and impact assessment. These technical challenges were also associated with substantial direct and indirect costs to the FMUs.
Certification financial assistance and technical support provided by certification coaches reportedly motivated FMUs to become certified and helped them through the process. Direct economic benefits such as premium prices and subsidies to help cover certification costs were considered by the FMUs as the best ways to promote voluntary certification of natural forest management in the country.

The above descriptive research provides a comprehensive portray of the dynamics and characteristics of the natural forests sector in the country. Chapter 6 - Conclusions, highlights the opportunities and constraints that those responsible for managing FMUs have had to improve forest management practices. That not all FMUs were either able to take advantage of new available programs and funding, or able to overcome barriers towards adopting FSC certification demonstrates the heterogeneity of preferences and characteristics of the timber companies. Although no definitive strategy emerges at this stage on how to better capture the compiled information contained in this volume into the design of an empirical evaluation, it seems clear that this new knowledge sets the basis on which discussions towards a next step can be taken. This future work entails the formulation of a theory of change to guide the evaluation strategy, the specification of assumptions, and the definition and testing of hypotheses to make the range of impacts of FSC certification visible. 


\title{
Impact evaluation background of FSC certification of natural forests The case of Indonesia
}

\author{
Claudia Romero, Francis E Putz, Erin O Sills, Manuel R Guariguata, \\ Paolo O Cerutti and Guillaume Lescuyer
}

\subsection{Introduction}

Certification of sustainable forest management has been promoted as a tool for maintaining or enhancing forest values (i.e. biophysical, social, economic, and policy) for more than twenty years. Tapping into this experience to learn about the contribution of forest management certification to the maintenance or improvement of a range of forest values should be a priority.

Given limited budgets for promoting the conservation and responsible management of tropical forests, it is critical to identify the most effective interventions. However, there is clearly no 'silver bullet' but interventions that work better when implemented in particular ways to achieve particular outcomes in particular times and places, and often interacting with other programs in specific ways. This realization highlights the importance of evaluating the impacts ${ }^{1}$ of any given intervention in different regions, and in parallel, exploring the heterogeneity in implementation (i.e., due to contrasting contextual factors including legal frameworks and characteristics of social actors and processes). Well-structured, verifiable and objective information about both implementation and impacts could inform negotiations, decision-making, and resource allocations to future conservation interventions (i.e., responsible management of natural resources with multiple goals) that aim to maintain forest values.

Lack of adequate knowledge on the outcomes of past and present forest-related programs and projects deprives governments at all levels, forest managers and suppliers of forests goods and services, consumers of these, and society at large,

1 The positive and negative, primary and secondary longterm effects produced by a development intervention, directly or indirectly, intended or unintended (OECD 2002). of the proper foundation on which to base sound future resource management decisions. Inadequate understanding of the outcomes that lead to multiscale impacts of forest management choices as taken by public or private forest companies risks creating or maintaining an unacceptable balance of costs and benefits for those directly and indirectly affected, and as such, might serve to perpetuate ecological, social, economic, and policy failures.

Certification of responsible forest management is a multi-layered intervention that takes place both in complex contexts and continuous change. Within these contexts there is a range of interested parties involved all the way from the early stage of accessing rights to the timber resource and planning, down the value chain to harvesting and trading it, to selling to the ultimate consumer.

Parties are most likely to learn from an evaluation carried out in a transparent manner, with integrity and inclusiveness so that results can potentially address accountability concerns (Farley et al. 2012; Rogers 2012). Such an evaluation could jointly generate knowledge with a range of people and institutions both interested and affected by its implementation (Romero and Castrén 2013; Romero et al., 2013). This logic follows on the perception of the evaluation endeavor as an opportunity (besides a vehicle) for inclusion and for giving voice to those affected and interested in certification a space for reflection and deliberation; as well as a tool for internalizing lessons learned after past mistakes and successes.

At the same time, given the stakes inherent to such learning exercise through an appropriately planned evaluation, those responsible for carrying out the evaluation must be independent researchers without explicit or ambiguous agendas regarding the development and potential outcomes of the assessment (GAO 2009; Gertler et al. 2011; Perrin 2012; PROFOR and FAO 2011; Stern 


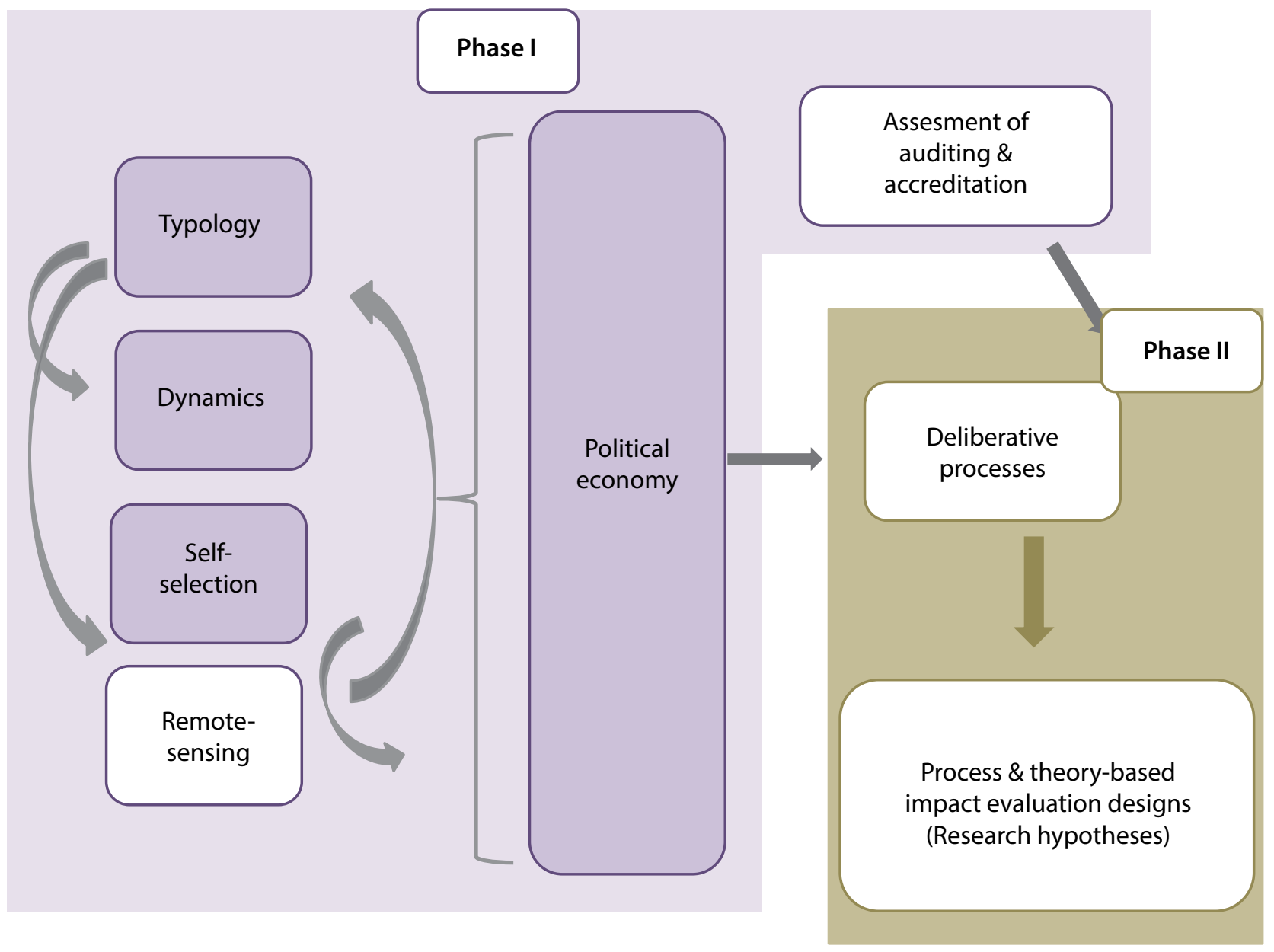

Figure 1.1. Integration of studies that generate information (Phase I) to facilitate discussions with a variety of stakeholders and identify the key elements of a theory-based and a process evaluation designs during the second stage of research to assess the impacts of FSC certification. Results from studies shaded in dark purple boxes are included in this document.

et al. 2012). The need for independence is widely recognized in policy circles and beyond. Demonstrated independence of the evaluation process can also enhance the probability of utilization of the knowledge gained and thus boost its potential to influence both policy and actions on the ground (Bamberger 2009).

CIFOR is undertaking a broad research effort to develop an independent evaluation of FSC certification impacts ${ }^{2}$ with stakeholder input, which focuses on FSC certification of natural

2 Certification impacts are changes in the forest and surrounding areas that are attributable to the influence of certification on participating FMUs, neighboring communities, forest workers, and local and national governments. Impacts can be positive or negative, primary or secondary, direct or indirect, short or long term, intended or unintended (OECD 2002). tropical forests. This Occasional Paper (OP) reports on Phase I (Figure 1.1), the preparatory stage to an eventual empirical evaluation. The overall objective of this stage is to gather information required to design an impact evaluation that would be credible (i.e., true and technically adequate for handling evidence), salient (i.e., relevant and of value to decision-makers and other evaluation users), and legitimate (i.e., fair in its knowledge gathering, unbiased and respectful). As such, the goal of the studies is to serve as the foundation to design an impact evaluation framework of the impacts of FSC certification of natural forests in a participatory manner with interested parties; from institutions and organizations, to communities and individuals. We hope this framework is robust enough to respond to the needs of the evaluation challenge, and at the same time sufficiently flexible to adapt to the special characteristics and the certification history and dynamics in each country. 
The four background studies (dark purple in Figure 1.1) in this volume were carried out during late 2013 and 2014. The studies mentioned in the clear boxes from Phase I (Assessment of Auditing $\&$ Accreditation and Remote-Sensing Analysis of FSC Impacts) are also part of this initial stage but their results will be reported elsewhere. This initial stage includes refining our research hypotheses about the potential impacts of certification. By publishing this volume we also hope to build a knowledge sharing platform to engage others involved in evaluating certification as well as in future discussions about the role of certification in forest conservation and its implications for local livelihoods.

\subsubsection{Evaluation rationale and activities}

There are two components of the evaluation that require broad participation and discussion (Figure 1.2). First, the process evaluation (light- brown shaded box), that aims to determine if the FSC intervention was implemented by managers of forest management units (FMUs) according to how it was designed. Key components of this evaluation are the activities of auditing, which provides an independent verification that operations in a forest management unit comply with FSC standards, and accreditation, which offers independent quality assurance of the auditing process. Process evaluation requires that evaluation researchers bring the participation and engagement of parties involved in the implementation of the intervention. Project partners for this type of evaluation include NGOs and other organizations locally relevant to the implementation of certification (i.e., certification coaching institutions; sponsoring organizations); certifying bodies; auditors; accreditation institutions (ASI) and personnel; FSC personnel; managers and workers of forest harvesting operations (i.e., FMU managers).

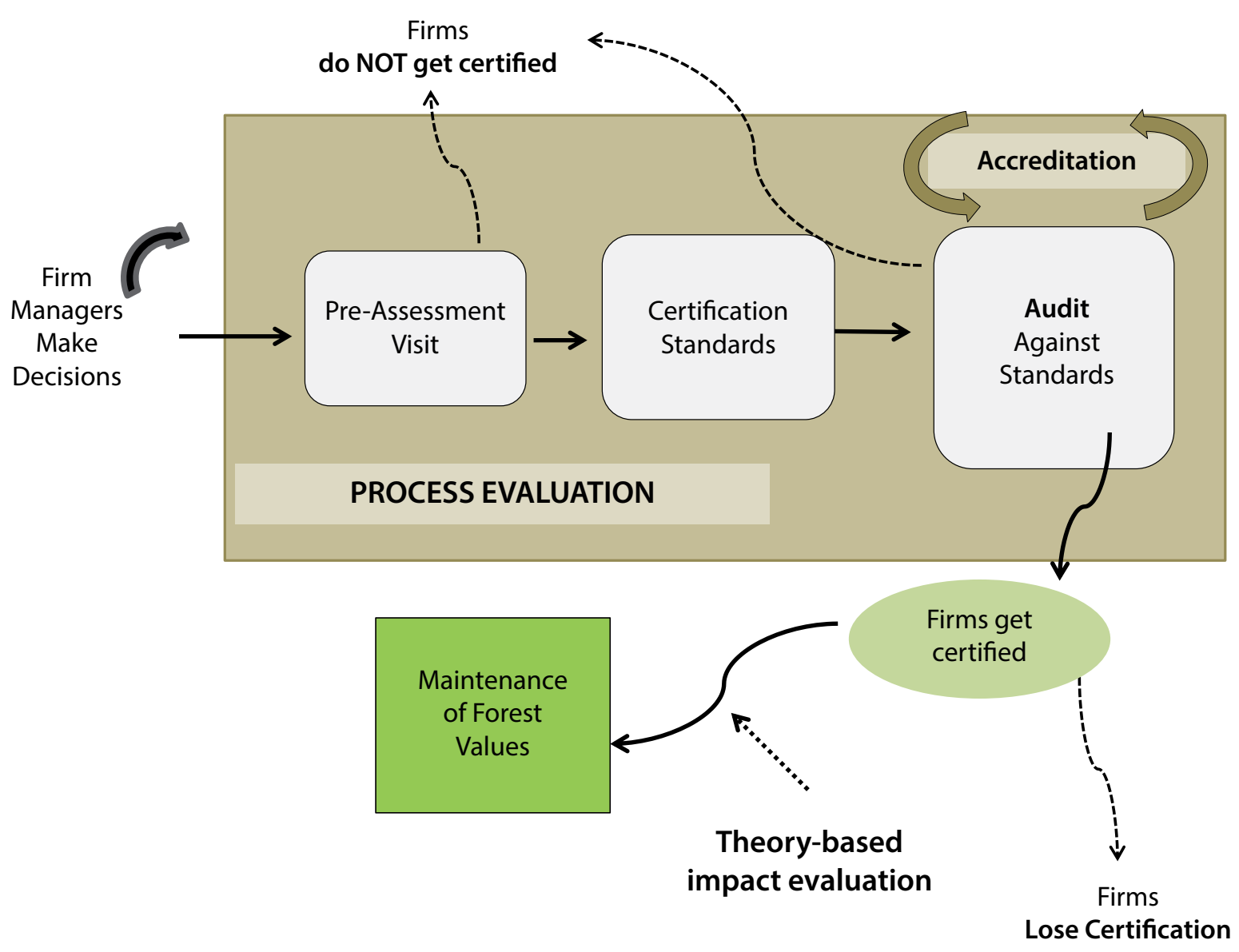

Figure 1.2. Schematic representation of key steps and decisions related with FSC certification process. The light brown-shaded box indicates activities to be assessed during the process evaluation (e.g., auditing and accreditation). The theory-based evaluation assesses whether once FSC certification has been implemented as designed it contributes to the maintenance of forest values. 


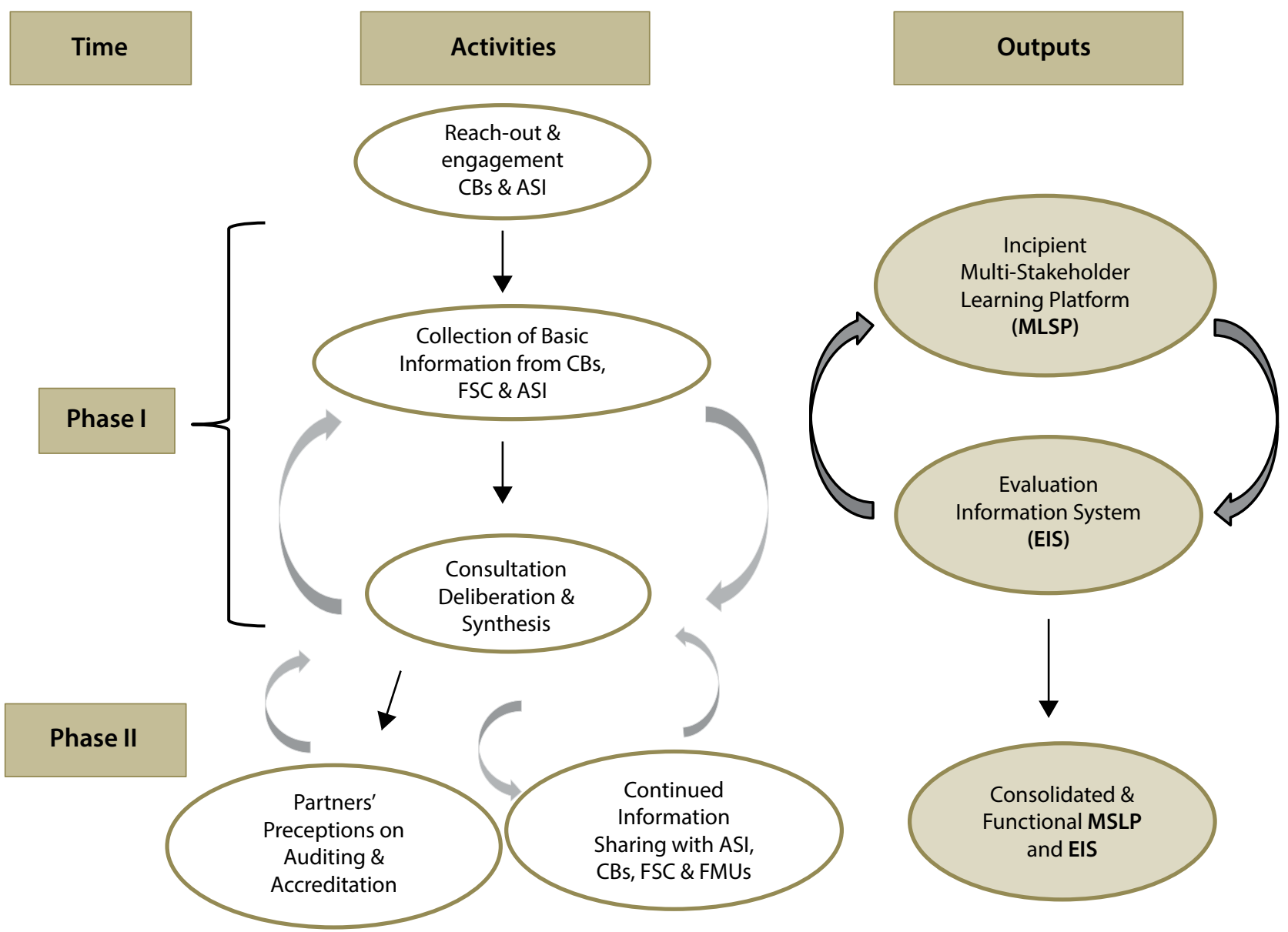

Figure 1.3. Operational model of the process throughout the different stages of FSC evaluation. The activities of deliberation and syntheses get iterated through the development of the evaluation. Both the Multi-Stakeholder Learning Platform (MSLP) and the Evaluation Information System (EIS) will continue to be consolidated as the evaluation work progresses. Other partners also become members of the MSLP as the evaluation research moves forward.

The second component of the evaluation is a theory-based, empirical impact evaluation that aims to assess if the FSC intervention as implemented and designed, it achieved its goals. For this evaluation the field-based research needs to draw on the expertise, and secure the participation of, a somewhat overlapping group of partners (e.g., NGOs, FMU managers and workers, local communities neighboring the forests, governments at more local levels; buyers).

Throughout the development of this research we started to consolidate an active learning community referred to as a Multi-Stakeholder Learning Platform (MSLP; Figure 1.3). Members include representatives of organizations that have helped forest operations become and remain certified; certifying bodies; active participants in audits; managers/selected workers of the forest operations; NGOs and other civil society organizations interested in tropical forest resources and their management; consumer groups; and members of the evaluation research team. One initial outcome of this platform is an Evaluation Information System (EIS), which consists of the set of institutions (e.g., interested, participating, and affected parties), arrangements (e.g., confidentiality and other non-disclosure agreements), and processes (e.g., workshops, questionnaires, mail surveys, phone interviews) through which information has been collected, discussed, and will be shared, published, and routed back into the decision-making processes that encompasses forest management.

Flows of information and understanding have been guided in an ongoing way to build and reinforce trust among those involved (Chatham House and UN-REDD 2011) and that enhance mutual social learning (Bidwell et al. 2013). The plan for the 
upcoming activities of the evaluation project is to continue strengthening the MSLP and to overall, make better use of the knowledge gained for the benefit of tropical forests and those communities living in and around them.

\subsection{FSC certification in Indonesia: this Volume}

In addition to informing plans for impact evaluation of certification, this volume contributes to the body of literature on evaluation of conservation interventions in general by describing the methods and findings of what should be the first steps of such impact evaluation. This process includes understanding the characteristics of the units to which the intervention applies, the dynamics of adoption of the intervention, and the contextual factors that might have influenced the process by which particular units self-selected for the intervention. Better understanding of these dimensions can help shape more perceptive and policy relevant impact evaluations, which in turn will feed back into social learning and improved decision-making.

The challenges of robust impact evaluation of conservations interventions have been discussed broadly (see Ferraro and Pattanayak 2006; Pattanayak et al. 2010; Jagger et al. 2010; Miteva et al. 2012; Baylis et al. 2015). In particular, various forms of selection bias make it difficult to establish attribution or causality (i.e., determine the extent to which the outcomes are due to the intervention rather than to the characteristics of units selected into the intervention). Impact evaluation is fundamentally about making this distinction, estimating the causal effect of an intervention as the difference between outcomes observed with the intervention and the outcomes that would have occurred under the 'counterfactual' scenario of no intervention. Reliable estimates of causal effects are essential for conservation and development practitioners and decision-makers in order to make adequate policy and practical choices about whether and how to expand interventions.

The starting point for these studies is to define the relevant unit of analysis, which we label a forest management unit, or $\mathrm{FMU}^{3}$. In Indonesia, these are timber concessions. Certification of a

3 FMU refers to both the forest area and the entity that manages the forest area.
Forest Management Unit (FMU) is determined by whether: a) the FMU voluntarily decides to pursue FSC certification, and b) a Certifying Body $(\mathrm{CB})$ audits and approves the management of the FMU (i.e., the standards stipulated by FSC are observed in the field). Both of these decisions are likely related to factors that also influence the outcomes of interest, which are the quality and extent of forest cover, the well-being of local populations, timber profits and their distribution, and aspects of governance. Thus, in order to estimate counterfactual outcomes, we cannot simply compare certified FMUs with non-certified FMUs. Neither can we simply compare the situation before and after certification, because that would not allow us to disentangle the effects of certification from other changes within a policy and/or economic context. To identify non-certified FMUs that reveal the counterfactual outcomes for certified FMUs, we need a detailed understanding of the factors that influence both certification and the outcomes of interest (i.e., the potential confounders). The four background studies presented in this volume assess the process of selection into certification from different perspectives, laying the groundwork for a rigorous impact evaluation.

The document is structured as follows. Chapter 2 (Political economy analysis of the timber and forest sectors in Indonesia) characterizes the contextual factors that determine the fate of natural managed forests (FMUs) in Indonesia, within the context of general discourses and forces that shape forested landscapes (e.g., actions that pertain to land cover change and the concept of territory, its zoning, and uses). Natural forests and their management are thus situated within the allencompassing politics and socio-economic setting of contested territories subject to different potential uses and associated stakes. Precursors of this study include work by Ruiz-Pérez and colleagues (2005) and Salazar and Gretzinger (2005).

The political economy analysis helps develop an understanding of the characteristics of the sectors and the historical, political, social, and economic contexts behind decisions that determined the potential for maintenance of the range of values of managed natural forests, and that in turn also influenced the policy environment. It also provides a timeline of key events and processes that might have influenced choices made (e.g., the fall of president Soeharto, decentralization). In that sense, the study identifies the policies and 
legal frameworks that underlie decisions regarding natural forest management, their evolution through time, and how other social and economic processes influenced land planning and classification, and land cover change. For example, whether being located on an active forest frontier, an old and more established frontier, or in a remote area, will indirectly influence the outcomes of certification in particular, and of forest management in general. The dynamics of these landscapes have been the subject of general (Chomitz 2007) and countryspecific studies (e.g., Pacheco 2012 for Brazil). Also, decisions have been taken at a range of levels, depending on the mode of governance and institutional regimes in the country as well as in response to policy shifts (Coleman 2009). This chapter also provides an account of the emergence of FSC in Indonesia and how it might have influenced the evolution of regulatory frameworks related to national certification schemes (e.g., LEI) and the design and development of legality certification (e.g., SVLK).

The existence of these pathways of influence have been previously reported (Overdevest 2010, Cashore and Stone 2012) but empirical demonstration of their existence is so far lacking and might not even be feasible.

A deeper understanding on the characteristics of the FMUs operating in natural forests is provided in Chapter 3 (Typology of the timber and forest sectors). This study provides a systematic way to appreciate similarities and differences among FMUs based on attributes that influence their probability of becoming certified as well as the expected outcomes of certification. Where FMUs that are already doing proper management become certified, the additionality of the intervention will be small (Salazar and Gretzinger 2005; Blackman and Rivera 2011).

FMUs are located along a certification continuum of forest management practices that overlap with particular stages in the certification process (e.g., from never engaged in FSC certification either to lack of interest or for having failed to become certified, to having remained certified for several years or having lost certification; see Romero et al. 2013). Classification of FMUs into the simple categories of "certified" and "non-certified" fails to capture this complexity which needs to be disentangled so to estimate the impacts of certification. Thus the typology presented in this chapter helps to distill the relationships among groups of variables and overall differences among FMUs. Specifically, the typology presents a static and current configuration of groups of similar FMUs at different stages along the certification continuum at one point in time (i.e., today). Information provided by the typology can help guide and gain insights for the construction of the counterfactual group.

Getting involved in certification is not a one-time choice, and the Certification Dynamics study

(Chapter 4) documents the annual decisions made by FMUs along the certification continuum but adapted to information availability and the nature of the FSC implementation process. In doing so, we were hoping to capture particular windows of time when contextual factors might have either facilitated or else obstructed engagement in certification, and in general, to detect patterns of decisions made vis à vis certification by FMU managers at particular times. These decisions are subject to change over time in response to a variety of political, economic, and other factors related to the timber and other associated sectors (e.g., investments, competing opportunities, market realities, changing legal frameworks). In particular, contextual factors that operate at local, national, and international levels can influence FMU's decisions to opt for certification and, once certified, to remain so. Market dynamics (e.g., consumer preferences and acquisition power) change and in turn influence suppliers' decisions vis à vis certification. Shifting legal frameworks and their enforcement, changes in the certification standards, novel technical capacities, technological innovations, global/regional/national economic conditions, availability of external support, and cost-benefit ratios are among the factors that can affect FMU decisions about certification (Nebel et al. 2005; Kollert and Lagan 2007; Crow and Danks 2010; Chen et al. 2011).

At this stage it seemed important to determine what could have been the motivations behind the choices made by FMUs. For that purpose, Chapter 5 presents findings from interviews and a literature review about the factors that influenced the process of self-selection into certification. Although certification was initially conceived as a market mechanism that would provide a price premium for firms that followed audited management practices, firms have chosen to certify FMUs for a wide variety of reasons not directly related to the capture of "green premiums" which have been hard to come by. The private 
benefits of forest certification actually realized by firms are not consistent across time scales, regions, countries, and type of firms (Blackman and Guerrero 2012). In addition to improved management systems, studies have found that certified firms have enhanced learning and transparency, increased public confidence and social acceptance, social improvement, and greater environmental responsibility (Vidal and Kozak 2008, Araujo et al. 2009; Cubbage et al. 2010). A review of available literature on certification decisions, along with analysis of trends of the dynamics study (Chapter 3) helped to structure the methodology of this chapter. Semi-structured interviews and informal conversations were held with a range of social actors with stakes on FSC certification.

The final chapter (Conclusions) presents an overview of the different perspectives that should be considered in design of an impact evaluation. It brings together some of the key information of the preceding chapters to highlight issues to consider in the empirical data collection stage when selecting key outcomes to evaluate and construct a counterfactual. We hope to have built a solid foundation that will allow us to determine the implications of FSC certification for the forests, local people, and other stakeholders in Indonesia.

\subsection{References}

Araujo M, Kant $S$ and Couto S. 2009. Why Brazilian companies are certifying their forests? Forest Policy and Economics 11: 579-585.

Chen J, Tikina A, Kozak R, Innes J, Duinker P and Larson B. 2011. The efficacy of forest certification: perceptions of Canadian forest products retailers. The Forestry Chronicle 87:636-643.

Bamberger M. 2009. Making smart policy: Using impact evaluation for policy making. Casestudies on evaluations that influenced policy. The World Bank. Poverty Reduction and Economic Management Series \# 14. 75 pp.

Baylis K, Honey-Rosés J, Börner J, Corbera E, Ezzine-de Blas D, Ferraro PJ, Lapeyre R, Persson, Pfaff M. and Wunder S. (In press). Mainstreaming impact evaluation in nature conservation. Conservation Letters.

Bidwell D, Dietz T and Scavia D. 2013. Fostering knowledge networks for climate adaptation. Nature Climate Change 3: 610-611.
Blackman A and Guerrero S. 2012. What drives voluntary eco-certification in Mexico? Journal of Comparative Economics, 40: 256-268.

Blackman A and Rivera J. 2011. Producerlevel benefits of sustainability certification. Conservation Biology, 25: 1176-1185.

Cashore B and Stone M. W. 2012. Can legality verification rescue global forest governance? Analyzing the potential of public and private policy intersection to ameliorate forest challenges in Southeast Asia. Forest Politics and Economics 18; 13-22.

Chen J, Tikina A, Kozak R, Innes J, Duinker P and Larson. B. 2011. The efficacy of forest certification: Perceptions of Canadian forest products retailers. The Forestry Chronicle 87:636-643.

Chatham House and UN-REDD. 2011. Guidance for the Provision of Information on REDD+ Governance (Draft). London and Geneva. $42 \mathrm{pp}$ (available at http://theredddesk. org/resources/draft-guidance-provisioninformation-redd-governance; accessed Jan 2015).

Chomitz K. 2007. At Loggerheads? Agricultural Expansion, Poverty Reduction, and Environment in the Tropical Forests. World Bank.

Crow S. and Danks C. 2010. Why Certify? Motivations, outcomes and the importance of facilitating organizations in certification of community-based forestry initiatives. Small Scale Forestry 9:195-11.

Cubbage F, Diaz D and Yapura P. 2010. Impacts of forest management certification in Argentina and Chile. Forest Policy and Economics 12: 497-504.

Farley K, Lucas S, Molyneaux J and Penn K. 2012. Impact evaluations of agriculture projects. Millennium challenge corporation. Principles into practice. $33 \mathrm{pp}$.

Ferraro P. 2009 Counterfactual thinking and impact evaluation in environmental policy. New Directions for Evaluation 122: 75-84.

Ferraro P J. and Pattanayak S. 2006. Money for nothing? A call for empirical evaluation of biodiversity conservation instruments. PLOS Biology 4:482-488.

GAO. United States Government Accountability Office 2009. Program evaluation: A variety of rigorous methods can help identify effective interventions. Washington, DC. 49 pp.

Gertler PJ, Martinez S, Premand P, Rawlings LB and Vermeersch CMJ. 2011. Impact 
evaluation in practice. Washington D.C., World Bank. Online at: http://siteresources. worldbank.org/EXTHDOFFICE/ Resources/5485726-1295455628620/Impact_ Evaluation_in_Practice.pdf

Jagger P, Sills EO, Lawlor K and Sunderlin WD. 2010. A guide to learning about livelihoods impacts of REDD+ projects. CIFOR Occasional Paper 56. CIFOR, Bogor, Indonesia.

Kollert W and Lagan P. 2007. Do certified tropical logs fetch a market premium? A comparative price analysis from Sabah, Malaysia. Forest Policy and Economics 9:862-868.

Miteva DA, Pattanayak SK, and Ferraro PJ. 2012. Evaluation of biodiversity policy instruments: what works and what doesn't? Oxford Review of Economic Policy 28: 69-92.

Nebel G, Quevedo L, Jacobsen JB and Helles F. 2005. Developing and economic significance of forest certification: the case of FSC in Bolivia. Forest Policy and Economics 7:175-186.

[OECD] Organisation for Economic Co-operation and Development/[DAC] Development Assistance Committee 2002. Glossary of key terms in evaluation and results based management. The DAC Working Party on Aid Evaluation, OECD, Paris. www.oecd.org/ dataoecd/29/21/2754804.pdf.

Overdevest C. 2010. Comparing forest certification schemes: the case of ratcheting standards in the forest sector. Socio-Economic Review 8: 47-76.

Pacheco P. 2012. Actor and frontier types in the Brazilian Amazon: Assessing interactions and outcomes associated with frontier expansion. Geoforum 43: 864-874.

Pattanayak SK, Wunder S and Ferraro PJ. 2010 Show me the money: Do payments supply environmental services in developing countries? Review of Environmental Economics and Policy 4: 254-274.
Perrin N. 2012. Linking Monitoring and Evaluation to Impact Evaluation. Impact Evaluation Notes \#2. InterAction: A United Voice for Global People and Rockefeller Foundation. 22 pp.

PROFOR and FAO. 2011. Framework for assessing and monitoring forest governance. Program on Forests -PROFOR and Food and Agriculture Organization-FAO. Washington and Rome. 36 pp.

Rogers P. 2012. Introduction to impact evaluation. Impact Evaluation Notes \#1. InterAction: A United Voice for Global People and Rockefeller Foundation. 21 pp.

Romero C and Castrén T. 2013. Approaches to measuring the conservation impact of forest management certification. PROFOR, World Bank, Washington, D.C. 42 p.

Romero C, Putz FE, Sills E, Guariguata MR, Cerutti PO and Lescuyer G. 2013. An overview of current knowledge about the impacts of forest management certification. CIFOR Occasional Paper 99.

Ruiz-Pérez M, de Blas DE, Nasi R, Sayer JA, Sassen M, Angoue C, Gami N, Ndoye O, Ngono G, Nguinguiri JC et al. 2005. Logging in the Congo Basin: a multi-country characterization of timber companies. Forest Ecology and Management. 214: 221-236.

Salazar M and Gretzinger S. 2005. Costos y beneficios de la certificación forestal y mecanismos para la resolución de obstáculos comunes. WWF Centroamérica and PROARCA. San José, Costa Rica. 80 pp.

Stern E, Stame N, Mayne J, Forss K, Davies K and Befani B. 2012. Broadening the range of designs and methods for impact evaluations. DfID Working Paper 38. 127 pp.

Vidal N and Kozak R. 2008. The recent evolution of corporate responsibility practices in the forestry sector. International Forestry Review 10:1-13. 


\title{
2 The political economy of forest land-use, the timber sector, and forest certification
}

\author{
Ahmad Maryudi ${ }^{1}$
}

\subsection{Introduction}

Policies and goals of forest conservation, use, and management evolve dynamically over time, as determined by individual and societal values and socio-economic conditions as well as political conditions (Cubbage et al. 2007). Forestry includes diverse stakeholders at various scales (Krott 2005); domestic actors interact with international/transnational forces to shape resource use policies (Bernstein et al. 2010, Gellert 2010). Forest policies are therefore taken at a range of levels, depending on modes of governance and institutional regimes (Coleman 2009). Forest conservation and management are also strongly linked with development activities (de Camino 2005, Sandker et al. 2012), thus decisions about forest policies and management need to be understood within the broader frameworks of development, culture, and history (de Camino 2005).

This paper analyzes factors and policies that have shaped decisions in Indonesia related to forest management within the context of landuse and land cover change. It considers timber plantations and forest conversion to other landuses only insofar as they interact with natural forest management principally for timber. The paper also assesses the roles of structural factors, institutions, agents, and incentives on the decision-making processes of the forest sector. Since the Indonesian timber sector also operates within global markets, the paper also analyzes the interactions between global and local-national trade. In particular, it examines how the market-based policy instrument of certification both directly and indirectly affects land-use and forest quality.

1 Faculty of Forestry, Universitas Gadjah Mada, Indonesia.Email: maryudi76@yahoo.com
Use of an interdisciplinary approach is required to understand complex environmental governance, including that of the forest sector (Redclift 1998, Tacconi 2011). This paper employs political economic lenses, which incorporate the social, historical, economic, and political contexts in which policies emerge (Moncrieffe and Luttrell 2005, Adam and Dercon 2009). In particular, a political economy framework facilitates the understanding of 'local' sector/policy arenas so to offer explanations for the variation observed across and within sectors, including how institutions operate in different contexts and how these interactions affect policy-making, its implementation, and its outcomes (Moncrieffe and Luttrell 2005).

This paper starts with an analysis on the dynamics of land-use institutions and regulations in Indonesia. This analysis will allow greater understanding of the role of forests and forestry since the outset of land-use policy and planning. For example, the Basic Agrarian Law (BAL) No. 5/1960, - enacted as the principal law of land-use planning including for forestry - was "marginalized" by the Basic Forestry Law (BFL) No. 5/ 1967, which allowed expansive forestry operations. This section further sheds light on the prominent roles of the Ministry of Forestry (MoF) in the political hierarchy in Indonesia, which allowed it unilateral designation of vast areas of the country as State Forest. It analyses the conflicting regulatory frameworks and institutions with different mandates and goals over the past years that affect management of the country's forests.

Before analyzing the rise of Indonesia's timber sector which was based on strong domestic government-business patronage and support from the transnational networks of liberal capitalists (Gellert 2010), the paper briefly outlines forest regulations that related to the exploitation of natural forests. This part describes the forest concession 
system, how its scope and procedures have changed over time, and guidelines issued that were ostensibly intended to promote sustainable management. At the time of this writing, hundreds of concessions are held by a small number of people closely connected to the forest power holders in the government (Dauvergne 1997, Barr 1998, Barr and Sayer 2012). The concession system and the timber industry with which it was, and remains tightly linked, was based on a number of forest policies that provided the forest sector with opportunities to capture most of the benefits from exploitation of forest resources, which indirectly led to their overly-exploitation. This section also illustrates the widespread conversion of natural forests to plantations, which was also driven by the financial interests of concession holders (Barr et al. 2010).

Thereafter, the paper analyzes in more detail how unnecessarily destructive logging is manifested in the use of selective logging systems solely based on diameter cutting limits. While many studies have shown that well-stocked forests, like those in Indonesia prior to commercial logging, can be sustainably managed, typical harvesting practices result in the removal of large numbers of trees with excessive (and avoidable) damage on the residual stands and forest biodiversity (Abdulhadi et al. 1981, Bertault and Sist 1997, Elias 1998, Putz et al. 2000). Despite some efforts to stop these practices, they continue due to inadequate monitoring and enforcement. The remainder of the paper focuses on how the aforementioned institutional and regulatory frameworks in forestry in Indonesia have responded to forest certification as well as on how adoption of certification by forest concessions has been influenced by a number of factors at different geographical scales. Despite the recent increase in the area of certified natural forests in Indonesia, a number of key challenges remain to be addressed.

\subsection{Dynamics of land-use institutions and regulations}

Indonesia is characterized by complex landscapes of physical geography, institutions, and legal frameworks that reflect the country's variety of socio-economic conditions and political situations. The country is mega-diverse both socio-culturally and ecologically. A population of a bit more than 230 million people representing about 300 ethnic groups is unevenly distributed across thousands of islands; more than two thirds of the population lives on the islands of Java, Madura and Bali, which account for only about $7 \%$ of the country's landmass (Statistics Indonesia 2010). The Outer Islands - all islands outside the densely populated islands of Java, Madura and Bali- vary substantially in the abundance of natural forests and mineral resources (Loeffler 1996).

The legal framework for land-use, planning, and allocation was established in the Indonesian Constitution of 1945 (Article 33), which stipulates that land, water, air and the natural riches contained therein shall be under control of the state and used for the maximum well-being of the people. Land-use and allocation were initially guided by the Basic Agrarian Law/ BAL No. 5/1960, which recognizes clear separation between state and private ownership. Land unregistered as private properties is claimed by the state. The law prohibits the possession of vast land areas by single institutions or individuals (Loeffler 1996, Thorburn 2004). It also prohibits the ownership of land by foreigners (McCarthy 2000). Despite adopting the clear separation between state and private properties, BAL recognizes customary land law concepts and institutions, locally referred to as Adat, at a limited extent so long as "not conflicting with national and state interest" (ContrerasHermosilla and Fay 2005, Wright 2011).

BAL No. 5/1960 was envisioned as an 'umbrella' law for all natural resource management in the country, including the forest sector (Moniaga 1993, Contreras-Hermosilla and Fay 2005). However, the implementing regulations for this law were not issued until enactment of sectoral laws for forestry (Basic Forestry Law/ BFL), mining, oil and natural gas, resettlement and transmigration, irrigation, and fisheries. The sectoral laws were considered to contradict the spirit and premises of BAL (Thorburn 2004). BFL particularly specified that land areas gazetted as state forest was no longer subject to BAL, but is under the jurisdiction and control of Forestry Directorate ${ }^{2}$ of the Ministry of Agriculture/ MoA (Thorburn 2004, ContrerasHermosilla and Fay 2005). In addition, BFL often conflicted with other sectoral laws (Thorburn 2004, Contreras-Hermosilla and Fay 2005). For instance, numerous mining companies operated in protected and conservation areas where such activities are prohibited (Contreras-Hermosilla and Fay 2005). Resettlement and transmigration programs also used forested areas (Thorburn 2004).

2 Transformed into Ministry of Forestry (MoF) in 1983 
Formally aimed at overcoming cross-sectoral planning problems, MoA prepared forest maps through Consensus-Based Forest Land-use Plans (Tata Guna Hutan Kesepakatan, TGHK) (McCarthy 2000, Brockhaus et al. 2012). TGHK specifically established the forest estate and designated its uses (McCarthy 2000, Brockhaus et al. 2012). It was "informally" aimed to ensure state control over the forests and to facilitate large scale commercial logging and forest conversions (Peluso 1995). In 1983, the first TGHK maps were produced for each province at a scale of 1:500,000, which suggests that they were only indicative (Santoso 2003, Brockhaus et al. 2012, Indrarto et al. 2012). TGHK maps were based on the consensus of mostly central government institutions but did not consider the perspectives of local communities (Santoso 2003). TGHK maps were supposedly based on the biophysical characteristics of the land (e.g., topography, precipitation, sensitivity to erosion, and vegetation), but their preparation was largely a desk exercise (Indrarto et al. 2012) and the maps often do not correspond with actually forested areas (Casson 2001).

TGHK classified 142 million ha (Table 2.1) approximately two-thirds of the country's entire land area- as State Forest (Kawasan Hutan) (McCarthy 2000, Thorburn 2004). All land unregistered as private properties was claimed by the state; those considered to have bio-geophysical features of forests, conservation or protection values were classified as State Forest (Santoso 2003). State Forest was subdivided into 1) protection forest, 2) nature reserves, 3) production forest for limited logging, 4) permanent production forest for commercial logging, and, (5) convertible production forests (MoF 1992 cited in
Santoso 2003). Through TGHK approximately 90 million hectares of the country's land area made available for legal timber exploitation. TGHK and its favor on timber production also came at the expense of customary practices. Many areas used for customary purposes were also classified as forests simply because they were not registered; the fact that customary lands were never registered meant that this area was large. The aforementioned clause of "national and state interests" was also frequently invoked to undermine customary land rights (Contreras-Hermosilla and Fay 2005). In that sense, customary rights were at best treated as weak usufruct rights (Colchester 2002).

Land-use planning efforts mostly consisted of the production of more detailed forest maps for the purpose of selecting areas for resettlement of people from the Java, Madura, and Bali. Between 1987 and 1990, the GoI conducted the Regional Physical Planning Project as the basis for its transmigration program/RePPProT (Peluso 1995, Brockhaus et al. 2012). The effort run by the National Coordination Agency on Survey and Mapping (Badan Koordinasi Survei dan Pemetaan Nasionall Bakosurtanal) aimed to improve the planning capacity of the Directorate General of Settlement Preparation through the use of more reliable maps and data on land availability for new settlements and agricultural estates (Peluso 1995, Brockhaus et al. 2012).

In 1992, the Law on Spatial Planning No. 24 was enacted to provide rules for spatial land-use planning (Rencana Tata Ruang Wilayah, RTRW), under authority of the National Development Planning Board (Badan Perencanaan Pembangunan Nasonall Bappenas) and the associated provinciallevel offices (Badan Perencanaan Pembangunan

Table 2.1. Indonesia's forest classes based on TGHK and Padu Serasi. Source: Forestry Planning Agency (1999) cited in Contreras-Hermosilla and Fay (2005).

\begin{tabular}{lcc}
\hline Functions & \multicolumn{2}{c}{ Area (ha) } \\
\cline { 2 - 3 } & \multicolumn{1}{c}{ TGHK } & Padu Serasi \\
\hline 1. Protection Forest (Hutan Lindung, HL) & $19,152,885$ & $20,500,988$ \\
2. Nature Reserves (Suaka Alam, SA) & $29,649,231$ & $33,519,600$ \\
3. Limited Production Forest (Hutan Produksi Terbatas, HPT) & $29,570,656$ & $23,057,449$ \\
4. Permanent Production Forest (Hutan Produksi Tetap, HP) & $33,401,665$ & $35,197.011$ \\
5. Convertible Production Forests (Hutan Produksi Konversi, HPK) & $30,000,000$ & $\mathbf{8 , 0 7 8 , 0 5 6}$ \\
\hline Total Forest & $\mathbf{1 4 1 , 7 7 4 , 4 2 7}$ & $\mathbf{1 2 0 , 3 5 3 , 1 0 4}$ \\
\hline
\end{tabular}


Daerah/Bappeda) (Brockhaus et al. 2012). The law empowered Bappenas, the Ministry of Home Affairs, and the Ministry of Environment to implement spatial planning and to determine uses of land areas (McCarthy 2000). In addition, it required provinces to prepare RTRW at the provincial level. Numerous inconsistencies between the TGHK and RTRWP have emerged since many areas defined as forest in the TGHK were reclassified in RTRWP (Santoso 2003, Indrarto et al. 2013). In fact, large areas initially designated for forests have been converted to nonforestry uses and were therefore considered to not fit any more with their planned functions (Fay et al. 2000, Santoso 2003). This indicates State Forest is affected by the ongoing interest of other economic actors.

The power of the MoF was threatened by Spatial Planning Law No. 24/ 1992 insofar as it curtailed its decision-making power over land-use allocation in the Forest Zone. This situation led to a power struggle (McCarthy 2000) in which the MoF produced its own integrated maps (Padu Serasi) based on TGHK maps that were then refuted by some provincial governments which continued to refer to their respective RTRWP (Santoso 2003, Brockhaus et al. 2012, Indrarto et al. 2012). At that time, the dispute was unresolved and land allocations continued to be based on the earlier regulations of the TGHK (McCarthy 2000).

Land and forest allocation in Indonesia became embroiled in more power struggles between ministries and other bodies of both central and local governments following the dramatic change in the country's political landscape at the end of 1990s. The twin Regional Governance Law No. 22/1999 and Fiscal Balancing Central and Regional Governments Law No. 25/1999 empowered local governments (provincial and district) through a process of decentralization. These laws conferred on the authorities of regional governments 26 obligatory and 8 optional tasks; forestry issues were among the optional tasks, but were often prioritized by local governments. The decentralization policy conferred substantial political and fiscal powers to local governments, which indirectly led to a large number of districts splitting (Burgess et al. 2012). Enabled by the new Forest Law No. 41/ 1999, regional officials of most forested-districts started to develop their own land-use plans (Potter and Badcock 2001).
Amidst the conflicting laws and regulations related to land-use, the Indonesian People's Consultative Assembly issued Decision TAP MPR IX/2001³ that required the central government to review, rationalize and harmonize all laws pertaining to land and other natural resources (ContrerasHermosilla and Fay 2005). In 2004, Law No. 22 was superseded by Law No. 32, which promoted recentralization. The new Law stated that regional autonomy "must guarantee harmonious relations between the Regions and the [central] Government... to continually uphold the [u] nified... Indonesia within the framework of promoting the national goals" (Barr et al. 2006: 52). District governments were eventually required to coordinate their landuse plans with provincial and national authorities. The national spatial plan was re-enacted in 2007 with Law No. 26/2007. The implementing regulation - Government Regulation/ GR No. 26/2008 - gave governors and ministers the right to override land-use decisions made by the districts. The overall authority responsible for drafting the decision was the National Spatial Planning Coordination Board, chaired by the Coordinating Minister for the Economy (Brockhaus et al. 2012).

Rules governing forest land allocation were revised in 2011 by the highest Constitutional Court following two separate judicial reviews on the forest law. Decision No. 45/ PUU-IX/ 2011 ruled out "unilateral" allocations (penunjukan) of forest zones by the state. It stated that forest land was a possession of the state only after formal field delineation (pengukuhan) agreed upon by relevant stakeholders. By 2012, less than 15\% of the Forest Zone was formally delineated through field checks, inter-sectoral consultations and mappings $(\mathrm{MoF}$ 2012). This implies that control over $85 \%$ of the forest Zones remains disputable despite strong claims of custodianship by the MoF.

Overlapping jurisdictions for land planning and allocation authorities have remained in place over the past few years. As part of the Letter of Intent with Norway to reduce greenhouse gas emissions from deforestation, forest degradation and peatland conversion, Indonesia implemented a two-year moratorium on the allocation of new concessions on forest land between 2011 and 2013. The moratorium was expected to constitute an important part of a broader forest and land use

3 TAP MPR is higher than Laws and only exceeded in the Indonesian legal system by the Constitution. 
reform agenda in the country (Brattskar 2011). Nonetheless, it focused on conserving peatland and primary forests; timber and plantation investments were to continue in other forest areas (Brockhaus et al. 2012). Maryudi (2011) skeptically argues that the moratorium will limitedly halt forest conversion as it exempted concessions covered by "in principle" permits. Conversions are still permitted in secondary forests; not less than 35 million hectares of forestland are classified as such (ibid.).

Competing land uses also occur in forestland used by customary communities. In 2012, through Decision No. 35/ PUU-IX/ 2012 the Constitutional Court ruled that all customary (Adat) forests be separated from the State Forest Zones and considered Adat properties. However as of December 2013 there were no implementing regulations for the decision. These implementing mechanisms are needed to define "customary," "customary communities," and "customary forests" for the purposes of gazetting lands. The statement that "the government decides Adat forests as long as it exists and is recognized" is subject to different interpretations. For example, in letter No. SE.1/
Menhut-II/ 2013 to provincial governors, district regents/mayors, and chiefs of local forestry services throughout Indonesia, the MoF claimed responsible for the designation of customary forests. This claim, perceived to be an attempt to delay recognition of customary forests, stimulated a national alliance of customary/indigenous people to urge parliament to pass a bill that recognizes and protects their rights so that they can manage their forests (AMAN 2013).

Overall, the regulations and institutions governing both land-use and allocation in Indonesia have been overlapping. Land-use allocation is now being determined by numerous institutions with often conflicting mandates and goals. The recent political dynamics pathway clearly poses huge challenges in forest land-use and allocation. Its prospects depend on the availability of implementing regulations, which remain to be made. In the meantime, MoF continues to rule over State Forest Land. In fact, over the past 30 years and up to the present, MoF approved forest operations have taken place in TGHKbased production forests.

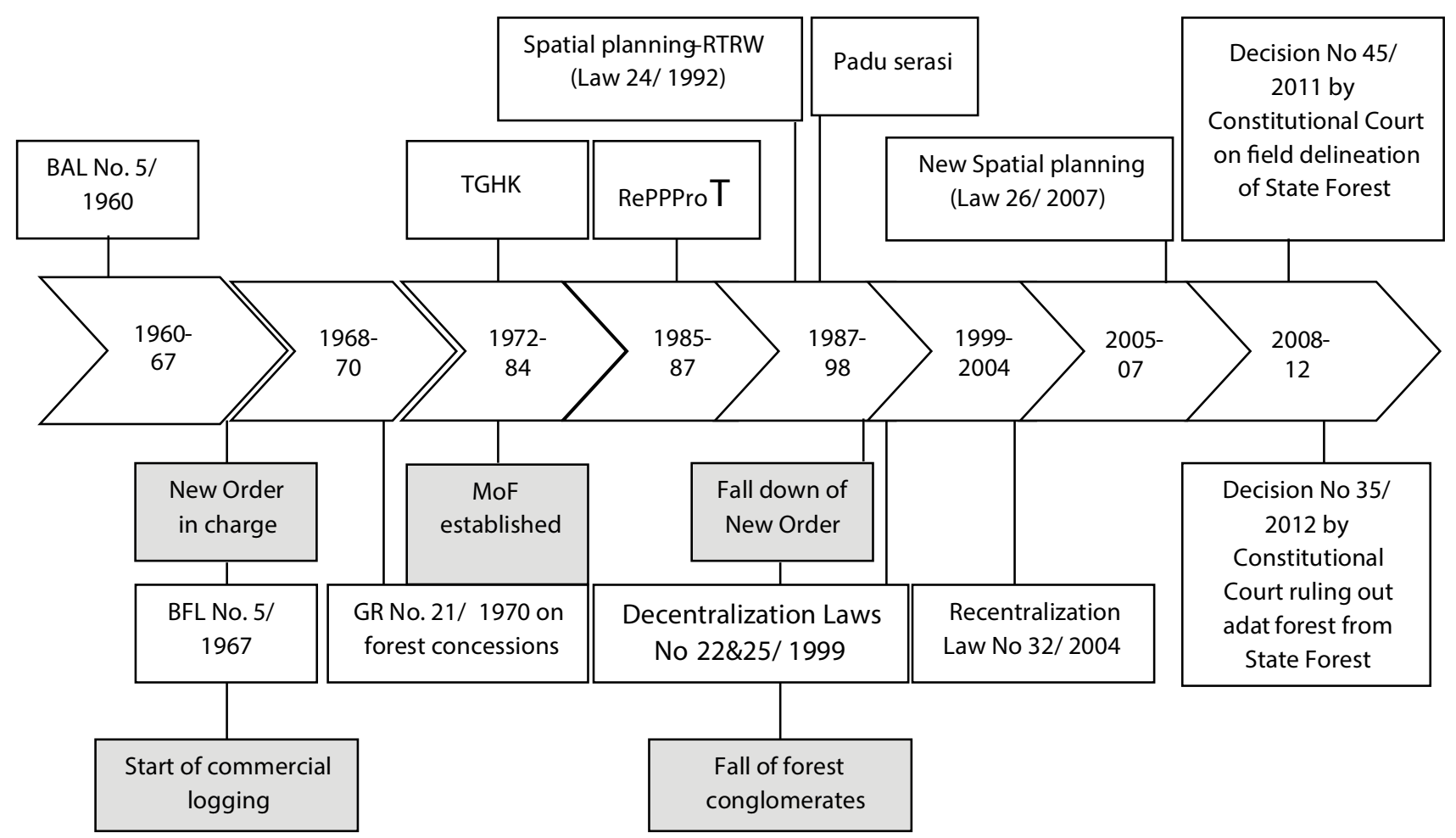

Figure 2.1 Timeline of land use planning and allocation regulations in Indonesia. The main events that pertain directly to natural forests and their management are highlighted in grey (abbreviations described in the acronyms section). 


\subsection{General and institutional aspects of forest and timber harvesting regulations}

\subsubsection{Forest cover dynamics}

Over the past 40 years forest cover and other conditions have changed dramatically in Indonesia. Until the end of the 1960s, despite customary forest uses on the Outer Islands, most of the forests of Kalimantan and Sumatra were basically intact if somewhat depleted of non-timber forest products and valuable timber (Poffenberger 1997). These forests contained high species richness (Whitmore 1984, Richards 1996), typically with 150-200 species of trees $(\geq 10 \mathrm{~cm} \mathrm{DBH})$ per hectare (Sist et al. 2003a). Commercial timber tree species in the Dipterocarpaceae typically represented $25 \%$ of stems $\geq 10 \mathrm{~cm} \mathrm{DBH,} 75-80 \%$ of the canopy and emergent trees, and half of the total basal area (see Sist et al. 2003a). When large-scale commercial logging commenced, the ecology of these forests was little known and not sufficiently taken into account, which resulted in widespread forest degradation.

As this paper will follow, large scale commercial logging with rampant and unnecessarily destructive practices has characterized Indonesia's forestry. Clearings for settlements and plantations have further led to massive deforestation and forest degradation over the past decades. By the mid1980s, it is estimated that more than 20 million ha of Indonesia's forests were severely degraded

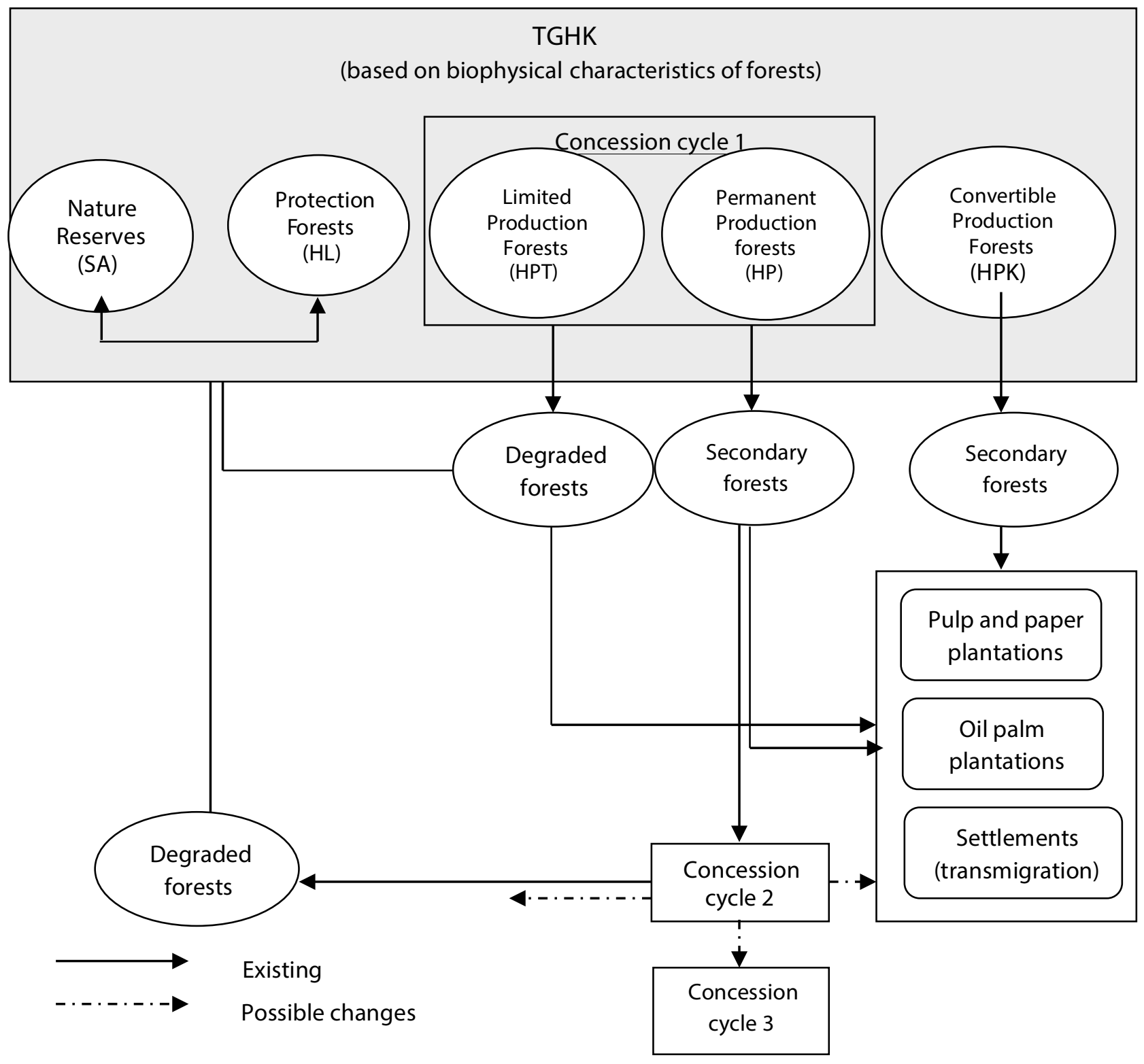

Figure 2.2 General forest land-use categories and transitions in Indonesia over the last years. 
(Hurst 1990); forest cover was reduced from $74 \%$ to $56 \%$ over the course of $30-40$ years $(\mathrm{MoF}$ and FAO 1990). The annual rate of deforestation increased from 300,000 ha/year in 1970s to about a million ha/year in the early 1990s (World Bank 1990). Deforestation peaked at the end of 1990s at nearly 3 million ha/year (Sunderlin and Resosudarmo (1996). Despite government's data on the substantial decreases over the past few years (see MoF 2012), deforestation in Indonesia apparently did not decline. A recent study by Hansen et al. (2013) suggests that Indonesia recorded a high deforestation rate of 2 million ha/year from 2011 to 2012 .

\subsubsection{Forest regulations}

Prior to 1967 when large-scale commercial logging began in Indonesia, the forestry sector contributed little to the nation's economy. Logging was mostly in teak plantations in Java (Barr et al. 2006) whereas in the Outer Islands, natural forest was logged and the timber was processed in small mills and marketed locally (Poffenberger 1997, Kartawinata et al. 2001, Barr et al. 2006). The maximum permitted areas of forest concessions and logging parcels were 10,000 ha and 5,000 ha, respectively, principally due to the absence of legal and regulatory frameworks for forest utilization in the Outer Islands (Barr et al. 2006). Log production in 1966 was 2.6 million $\mathrm{m}^{3}$ (MoF and FAO 1990). In 1965, Indonesia exported only $200,000 \mathrm{~m}^{3}$ of hardwood logs, which accounted for $<2 \%$ of overall timber exports from insular Southeast Asia (Barr et al. 2006).

BFL No. 5/1967 was enacted principally to facilitate exploitation of the country's vast natural forests (Poffenberger 1997, Thorburn 2004, Barr et al. 2006, Brockhaus et al. 2012). The New Order government led by president Soeharto with the advice of neo-liberal technocrats aimed to "build a capitalist developmentalist state" and favored foreign capital investment, including forest operations (Gellert 2010: 547). In the late 1960s, Indonesia was one of the poorest countries in the world and had suffered from a number of political conflicts (Christanty and Atje 2004, Barr et al. 2006). Log export from natural forests was seen as the fastest way to secure the income needed to pull the country from the brink of bankruptcy (Thorburn 2004, Barr et al. 2006). Indonesia therefore embarked on large scale commercial logging even though neither formal forest delineations nor detailed forest management regulations were in place.
In 1970, GR No. 21 was issued to guide implementation of BFL. This regulation specified how commercial logging operations centered on a concession system was to operate. It delineated the scope and procedures for granting concessions as well as the rights and obligations of concession holders. Concessions were granted to private, state, and para-statal companies for 20 years after an initial agreement (called Forestry Agreement) between the applicants and the government, and physical surveys on the requested locations (Greenomics 2004a). Hundreds of concessions were rapidly issued via a discretionary non-bidding procedure. The great majority of these were distributed to a few groups, mostly presidential cronies, which resulted in the formation of large corporate conglomerates (Dauvergne 1997, Poffenberger 1997, Barr 1998, Gellert 2010).

The requirement for concessions to prepare forest management plans was specified in GR. No. 33/ 1970. Before commencement of timber harvests, concessions were obliged to craft both long-term (10-year) and annual plans based on pre-logging timber stock inventories. Forest operations were regulated in the Decree of General Directorate of Forestry No. 35/Kpts/DD/I/1972 on the Indonesian Selective Cutting System (Tebang Pilih Indonesia, TPI). In 1989, TPI was revised into the Selective Cutting and Replanting System (Tebang Pilih Tanam Indonesia, TPTI), which additionally obliges concession holders to undertake enrichment planting on post-harvest compartments three years post-logging on the areas with limited potential crop trees (Yasman 1998, Sist et al. 2003a, Wahyudi 2011). It later became evident that the silvicultural systems benefited very few people and that they were seldom implemented due to the near absence of monitoring and enforcement; the result was the massive forest degradation discussed in the next section. Recently, intensive silvicultural system, locally referred to as Silvikultur Intensif (SILIN), is now being trialed in several concessions. Instead of encountering the limitation of TPTI, the new approach appears to promote more harvests from the forests (Prasetyo et al. 2012). As a consequence, the system potentially put more pressure on resources.

The economic and political crises of the late 1990s stimulated reformulation of forest policy and regulations. For example, to accommodate decentralization, BFL was replaced with Law No. $41 / 1999$. Procedures related to forest concessions 
were also revised in 1999 with the issuance of GR. No. 6 that regulates auction processes for the granting of concessions. This regulation also limited the size of concessions to 50,000 ha and the overall concession holdings of any timber group to a maximum of 100,000 ha within a province and 400,000 ha in the entire country. The only exception to the regulation was West Papua where individual concessions were limited to 100,000 ha and group holdings to 200,000 ha. It was argued that limits on the sizes of forest concessions would prevent the conglomeration of forest utilization into a few hands (Greenomics 2004a). In practice however, the limits were often circumvented when concessionaires held large concessions under different names (Pribadi 2004).
Authority over issuance of forest concessions, as further defined in MoF Decree No. 05.1/ Kpts-II/2000, was to be shared between the central government $(\mathrm{MoF})$ and local (provincial and district) governments. While large concessions $(10,000-50,000 \mathrm{ha})$ remained under the authority of the MoF, provincial and district governments were permitted to issue small-scale forest concessions and conversions for up to 10,000 ha and 100 ha, respectively. This policy was enacted principally in response to the aforementioned twin laws related to decentralization. The result was uncontrolled issuance of small-scale concessions, principally by local governments of forest-rich regions (Greenomics 2004a, Barr et al. 2006).

Table 2.2. Regulatory frameworks related to natural production forest management (based on Ruslandi et al. 2014).

\begin{tabular}{|c|c|c|}
\hline Regulation & Subject & Main contents \\
\hline Law No. 5/1967 & BFL & Basis for Gol control over forests \\
\hline GR 21/1970 & $\begin{array}{l}\text { Forest concessions and forest product } \\
\text { utilization }\end{array}$ & $\begin{array}{l}\text { Concessions should be formally linked with a forest- } \\
\text { product processing industry }\end{array}$ \\
\hline GR 33/1970 & Regulates forest planning & Preparation of forest management plans \\
\hline FD35/Kpts/DD/1972 & $\begin{array}{l}\text { Indonesian selective logging rules } \\
\text { (TPI) }\end{array}$ & The silvicultural system for natural production forest \\
\hline GR 51/1998 & Sets royalties & Payment of volume-based forest royalties \\
\hline $\begin{array}{l}\text { MoF Decree 485/ } \\
\text { Kpts/II/1989 }\end{array}$ & $\begin{array}{l}\text { Modification of selective logging rules } \\
\text { to include enrichment planting where } \\
\text { needed }\end{array}$ & $\begin{array}{l}\text { Modifications of the silvicultural system for natural } \\
\text { production forest }\end{array}$ \\
\hline Law No. 41/1999 & Amends BFL & $\begin{array}{l}\text { Supersedes Law } 5 / 1967 \text { to comply with } \\
\text { decentralization regulations }\end{array}$ \\
\hline GR 6/1999 & $\begin{array}{l}\text { Modifies regulations about forest } \\
\text { concessions \& forest product } \\
\text { utilization }\end{array}$ & $\begin{array}{l}\text { - Supersedes GR } 21 / 1970 \\
\text { - Limits the size of concessions } \\
\text { - Provincial \& district governments can grant small- } \\
\text { scale concessions } \\
\text { - Concessions not obliged to linked to forest- } \\
\text { product processing industries }\end{array}$ \\
\hline GR 34/2002 & $\begin{array}{l}\text { Forest administration \& the } \\
\text { formulation of management plans }\end{array}$ & $\begin{array}{l}\text { - Amends PP6/1999 } \\
\text { - Revokes authority of local governments to grant } \\
\text { forest concessions } \\
\text { - Mandatory sustainable management } \\
\text { - Monitoring, verification and sanctions }\end{array}$ \\
\hline $\begin{array}{l}\text { Decision No. } 226 / \mathrm{VI}- \\
\text { BPHA/2005 revised } \\
\text { in P.9/VI/BPHA/2009 }\end{array}$ & SILIN & $\begin{array}{l}\text { - Reduces of minimum cutting diameters by } 10 \mathrm{~cm} \\
\text { - Reduces minimum cutting cycle by } 5 \text { years } \\
\text { - Planting of commercial species along cleared lines }\end{array}$ \\
\hline $\begin{array}{l}\text { P.38/Menhut- } \\
\text { II/2009 } \\
\text { Amended to } \\
\text { P.11/Menhut- } \\
\text { II/2011 }\end{array}$ & $\begin{array}{l}\text { Standards \& guidelines for } \\
\text { sustainable natural production forest } \\
\text { management \& legality verification } \\
\text { (SVLK) }\end{array}$ & $\begin{array}{l}\text { Employ independent auditors to assure compliance } \\
\text { with forest management \& administration } \\
\text { regulations }\end{array}$ \\
\hline
\end{tabular}


The small concessions were given for a duration of 1-2 years (Barr et al. 2006), meaning that the holders consequently left the area after logging. In addition, overlaps between small concessions and existing large concessions frequently occurred that raised concern about "double logging" (Dermawan et al. 2006). Responding this, GR No. 34/ 2002 was issued to revoke the authority of local governments to grant forest concessions. In 2005 MOF started to verify small-scale concessions, the concessions are allowed to continue their operations when they are deemed to have fulfilled MOF's administrative requirements (Dermawan et al. 2006). Formally, sole authority to issue forest concessions has since returned to the $\mathrm{MoF}$, although some districts persisted in issuing small concessions (Dermawan et al. 2006).

Regulation GR 34/ 2002 also specifies mandatory sustainable forest management to be practiced in all forest concessions in Indonesia. In this scheme, concessions were to be assessed by an independent verification body (VB) against a set of criteria and indicators of forest sustainability developed by the MoF (Greenomics 2004b). The regulation further details administrative and financial sanctions imposed on concessions for non-compliances. For minor violations of forest regulations such as incomplete or else erroneous reports, governmental services for timber administration are suspended. Heavy financial penalties, ranging from 15-20 times of timber royalties, are imposed on such activities as cutting reproductive trees, logging in non-assigned annual harvest blocks, and in riparian and other protected areas. Persistent violations may result in the withdrawal of the concessions. This sanction is also applied to concessions that do not craft long-term and annual plans. In 2009, MoF further implemented mandatory timber legality assurance system (Sistem Verifikasi Legalitas Kayu, SVLK), as laid down in the Forestry Minister's Regulation P.38/Menhut-II/2009. SVLK is applied to all types of forest management units in both state (natural forests and plantations) and private lands.

\subsection{Forest product investment, trade and revenues}

\subsubsection{Vertically Integrated Timber Industries}

As earlier said, Soeharto's development strategy initially favored foreign investments, including the forest sector. Along with BFL, the government enacted foreign investment Law No. 1/1967 to facilitate commercial timber extraction (Gellert
2005). The law that featured tax exemptions and profit repatriation for foreign investors became an important incentive behind the timber boom in Indonesia (Kasa 1999). This was welcomed by the transnational liberal capitalists, such as the World Bank (WB) and foreign investors (Gellert 2010). In fact, the timber boom commenced with substantial involvement of multinational logging companies including Weyerheuser, Georgia Pacific, and Unilever (Gillis 1998).

In 1970, the government started to limit the involvement of these companies by awarding concessions to domestic-foreign joint ventures; starting in 1975, new concessions were only granted to domestic companies (Gillis 1998). By 1980, a total of 519 logging concessions covering about 53 million ha were held mostly by domestic private investors, plus three state-owned enterprises (Barr 1998). In 1983, only nine foreign-owned concessions remained by companies from Japan, Korea and Malaysia, as western companies pulled out of the timber sector (Gillis 1988). The number of concessions peaked at 580 in 1992 (Kusmana 2011) and were mostly located in Sumatra and Kalimantan (Poffenberger 1997). At that time about a third of the concessions were owned by 15 industrial groups led by president cronies, some who controlled forest areas over 2 million ha (Table 2.3).

Log production rose substantially from 1960s through the 1970s when Indonesia was a global leader in exports of tropical logs (Thompson and Duggies 1996), and production was $>20$ million $\mathrm{m}^{3} /$ year (Maryudi 2005). More than two-thirds of the logs were exported as unprocessed roundwood (Thompson and Duggies 1996). Over the 5 years of the first National Development Plan (19691974) of the New Order regime, forestry revenues increased by 2,800\% (Christanty and Atje 2004) and the sector earned approximately $20 \%$ of the country's foreign currency income (Kato 2005).

To capture more added values from forests, to create jobs, and to promote regional development, by the end of the 1970s the government started to impose increasingly stringent restrictions on $\log$ exports and to otherwise promote downstream industries (Barr 1998). Starting in 1977, the central government collected a mandatory deposit on log exports amounted to US\$ $4 / \mathrm{m}^{3}$ to finance construction of timber processing industries (preferably plywood mills), and doubled log export taxes on logs in 1978 (Gillis 1988, 
Table 2.3. Total concession area of Indonesia's 15 largest timber groups in 1990 (Barr 1998)

\begin{tabular}{lcc}
\hline Group & $\begin{array}{c}\text { Number of } \\
\text { Concessions }\end{array}$ & $\begin{array}{c}\text { Total } \\
\text { Concession Area } \\
\text { (thousand ha) }\end{array}$ \\
\hline Barito Pacific & 22 & 2215.5 \\
Korindo & 7 & 828 \\
Jayanti & 24 & 2726.5 \\
Bumi Raya Utama & 9 & 1060 \\
Indo Plywood & 2 & 350 \\
Alas Kusuma & 17 & 2248 \\
Surya Dumai & 7 & 904 \\
Satya Daya Raya & 12 & 1597 \\
Kayu Lapis & 14 & 1789 \\
Indonesia & 2 & 259 \\
Raja Garuda Mas & 2 & 855 \\
Kalimanis & 3 & 710 \\
Sumber Mas & 7 & 669 \\
Tanjung Raya & 7 & 1587 \\
Hutrindo & 17 & 85 \\
Tjipta Rimba Djaya & 1 & $\mathbf{1 7 8 8 3}$ \\
\hline Subtotal - Top 15 & $\mathbf{1 5 1}$ & $\mathbf{3 7 6 0 3}$ \\
Groups & $\mathbf{3 9 1}$ & $\mathbf{5 5 4 8 6}$ \\
Others & $\mathbf{5 4 2}$ & \\
Total & &
\end{tabular}

Dauvergne 1997). The government imposed a gradual ban on log exports from 1981 with a total ban in 1986 (Sidabutar 1988, Thompson and Duggies 1996). In reaction to this policy, the few foreign timber companies that remained pulled out of Indonesia (Dauvergne 1997), and domestic companies that were unable to invest in wood processing operations either sold their timber rights to larger firms or aligned with them (Barr et al. 2006).

The logging ban was effectively implemented due a combination of domestic politics - i.e. the authoritarian power and the development agenda of New Order Regime-, and the decline of $\log$ prices in global markets (Gellert 2003). The era of vertically-integrated companies then began with the imposition of high tariffs and log export bans in the 1980s. One result of these policies was that concession-holders had to sell virtually all of the timber to domestic wood industries at prices well below international log prices (Barr 2002). Indonesia’s domination in plywood markets was principally associated with cheap products (Daugverne 1997). The heavily subsidized industries only processed high quality $\operatorname{logs}$ and, as a consequence, there was a great deal of waste of timber in the forest but increased rates of exploitation to feed the rapidly increasing processing capacities (Poffenberger 1997).

The government supported forest industries especially for plywood production (Dauverne 1997). The number of plywood mills increased from only 21 in 1978 to 98 in 1985 (Hasan 1991). Plywood production skyrocketed at an annual rate of 59\% over the period 1973-1985 (Hasan 1991), and production reached 12.6 million $\mathrm{m}^{3} / \mathrm{yr}$ by the end of the 1980s (Barr 1998). Formerly the world's largest tropical hardwood log exporter, Indonesia became a major supplier of tropical plywood and veneer. Indonesia's share to the world's tropical plywood exports increased dramatically from around $7 \%$ in the early 1980 s to more than $75 \%$ in the early 1990s (Lyons 1995).

Japan made substantial early investments in commercial logging operations in Indonesia (Daugverne 1997) and was by far the main export destination for Indonesian forest products. Imports between 1987 and 1995 ( -3 million $\mathrm{m}^{3} /$ year), accounted for about three quarters of Indonesia's timber exports (Dauvergne 1997). Japan was particularly aggressive in securing supplies of tropical timber to meet the increasing domestic demands that could no longer be satisfied by timber from the Philippines and Malaysia, their former main providers (Manning 1971). The importance of China as a destination for Indonesia's timber-based products has increased by $48-71 \%$ annually between 1997 and 2002. In 2002, 30\% and $20 \%$ of the legal exports went to Japan and China, respectively, but one estimate of the illegal exports to China puts them at three times the legal figure (Lang and Chan 2006). Around the same time, the values of Indonesian forest product exports to EU countries and the USA were only $9 \%$ and $5 \%$, respectively (Profor 2012).

Indonesia's export earnings from wood products increased exponentially from only US\$200 million in 1981 to US\$ 3 billion in 1990 (Hasan 1991). This growth, attributable mostly to the plywood industry, was facilitated by the creation of Apkindo, a timber cartel. Apkindo was created by the state to act as a marketing apparatus to control the nation's plywood exports (Barr 1998), with membership compulsory for all plywood producers (Poffenberger 1997). Apkindo, which 
was run by Bob Hasan, a close associate with president Soeharto, issued export licenses and set export prices and production quotas (Dauvergne 1997, Barr 1998, Gellert 2010). It was aided by networks of marketing firms, whose roles were crucial in penetrating Japanese and other Asian markets (Gellert 2003, 2010). In practice, Apkindo used a "dumping policy" that allowed high quality plywood to be sold cheaply so that similar products from other countries, principally Malaysia, were at a competitive disadvantage (Dauvergne 1998).

In 1994, the WB unsuccessfully attempted to persuade the government to reform the vertically integrated processing mills and to liberalize timber trade by eliminating Apkindo's control (Gellert 2010). However, the economic crisis that struck Indonesia in 1997 facilitated the WB and its capitalist networks to force the government to implement the forest reform as the part of the Assistance Package by the International Monetary Fund (IMF) to rescue Indonesia's economy (Gellert 2010). The economic crisis that also struck many Asian countries, including Indonesia's export destinations, further affected Indonesia's plywood exports. Japanese plywood markets were severely depressed due to the decline of housing projects where Indonesian plywood was used for concrete forms and otherwise. A one-third decline of Japan's plywood imports combined with the steady influx of Malaysian plywood resulted in a substantial decline in Japan's imports of Indonesian plywood (UNECE/FAO 1998).

As part of the forest reform obliged by the WB, the government started to downsize its timber industries due the depleted timber stocks in natural production forests. From 2000 to 2003, the annual $\log$ production decreased by $50 \%$ to just about 10 million $\mathrm{m}^{3}$ (MoF 2008). This trend continued over the following years; annual log production between 2007-2011 averaged only 5 million $\mathrm{m}^{3}$ (MoF 2012). The number of logging concessions also declined to 292 by 2011 (MoF 2012). Many concession holders abandoned their concessions following the sharp decline of production after the initial harvest (Dauvergne 1997, Barr 1998). By 2011, there are only 292 active concessions (MoF 2012), the others were either withdrawn by MoF or simply abandoned the degraded forests after rampant logging. Forest concessions were apparently treated by companies as a way to obtain huge short-term profits

(Dauvergne 1997).
Concession holders linked with vertically integrated industries prior to the economic crisis were able to make excessive profits from timber extraction i.e. substantially more than the rates-of-return from other businesses (Scotland and Whiteman 1997, Gillis 1998). Rents from timber were initially regulated in GR No. 22/ 1967. The regulation obliged forest concessions to pay two types of fees: 1) a one-time Forest Concession Fee (Iuran Hak Pengusahaan Hutan, $\mathrm{IHPH}$ ) that varied with the size and the location of the concession of US\$ 2-5/ ha, and 2) volume-based timber royalties (Iuran Hasil Hutan, IHH). Following the issuance of GR No. 21/ 1970, IHH was paid at the mill gate rather than in the forest (Greenomics 2004b). This regulation encouraged forest concessions to practice "high grading", a practice in which only the best logs were harvested to avoid high IHH payments (Soedomo 2012). Low quality logs were mostly abandoned in the forest as "waste," which put heavy pressure on the forest resource as more harvests were conducted to satisfy the demand of growing timber processing industries.

Responding to obvious forest degradation due to unsustainable timber harvesting practices, in 1980 the government introduced the Reforestation Deposit Fund (GR No. 35/ 1980; Dana Jaminan Rebosasi, DJR). This fund was structured as a performance bond set at US\$ $4 / \mathrm{m}^{3}$ to implement reforestation one year after logging. DJR was to be paid at the end of the logging year but the volume of production was determined at the millgate. DJR was designed to be refunded upon completion of reforestation activities, but most of the concessionaires regarded DJR simply as another tax. They also presumed that payment of the DJR freed them from any reforestation obligations (Atje and Roesad 2004, Barr et al. 2010, Barr and Sayer 2012). Their interpretation was financially rational insofar as it was economically more profitable for the concession holders to relinquish DJR than to rehabilitate degraded concession sites (Barr and Sayer 2012).

The government transformed DJR into a nonrefundable levy and renamed it the Reforestation Fund (Dana Reboisasi, DR) in 1989 (Atje and Roesad 2004, Barr et al. 2010), but this policy change had limited impacts on concession management practices for the aforementioned reason because DR fees were relatively low (Scotland et al. 1999, Brown 1999, Subarudi and Astana 2001, Barr et al. 2010). DR was initially set at only US $\$ 7 / \mathrm{m}^{3}$ but was increased gradually over the following years to US\$13-20/ $\mathrm{m}^{3}$ -depending on the species (Table 2.4). Even with higher DR fees, forest concessions continued to enjoy 
Table 2.4. Required payments into the Reforestation Fund (DR) according to GR No. 92/ 1999.

\begin{tabular}{|c|c|c|}
\hline $\begin{array}{l}\text { Region, species and grade } \\
\text { of timber }\end{array}$ & $\begin{array}{l}\text { Rates } \\
\text { (USD) }\end{array}$ & Unit \\
\hline \multicolumn{3}{|l|}{ Kalimantan and Maluku } \\
\hline Shorea spp. & 16 & $\mathrm{~m}^{3}$ \\
\hline $\begin{array}{l}\text { Mixed tropical } \\
\text { hardwoods }\end{array}$ & 13 & $\mathrm{~m}^{3}$ \\
\hline \multicolumn{3}{|l|}{ Sumatra and Sulawesi } \\
\hline Shorea spp. & 14 & $\mathrm{~m}^{3}$ \\
\hline $\begin{array}{l}\text { Mixed tropical } \\
\text { hardwoods }\end{array}$ & 12 & $\mathrm{~m}^{3}$ \\
\hline \multicolumn{3}{|l|}{$\begin{array}{l}\text { Irian Jaya and Nusa } \\
\text { Tenggara }\end{array}$} \\
\hline Shorea spp. & 13 & $\mathrm{~m}^{3}$ \\
\hline $\begin{array}{l}\text { Mixed tropical } \\
\text { hardwoods }\end{array}$ & 10.5 & $\mathrm{~m}^{3}$ \\
\hline \multicolumn{3}{|l|}{ Indonesia } \\
\hline Ebony & 20 & Tonne \\
\hline Teak from natural forests & 16 & $\mathrm{~m}^{3}$ \\
\hline Fancywood & 18 & $\mathrm{~m}^{3}$ \\
\hline Sandalwood & 18 & $m^{3}$ \\
\hline Pulpwood & 2 & Tonne \\
\hline
\end{tabular}

windfall profits and aggressive logging remained more financially attractive than commitment to long-term concession management (Barr 2002). It is estimated that concessions captured 67$83 \%$ of the rents from timber harvest operations (Ruszicka 1979, Ahmad and Ramli 1991). Excessive profits caused concession holders to undervalue the resource and undermined any incentives to manage their concessions responsibly (see Gillis 1992, Barr 2002).

\subsubsection{Conversion of natural forests to timber plantations}

Together with rapid rates of deforestation and forest degradation in the mid-1980s (Hurst 1990) there were growing concerns about maintenance of the timber supplies for the country's processing industries (FAO and MoF 1990). Instead of focusing on improved natural forest management, development of fast-growing tree plantations (Hutan Tanaman Industri, HTI) was chosen as the main strategy to ensure national timber supplies (Potter and Lee 1998). HTI was also developed for pulp and paper industries as the government aimed to make Indonesia one of the world's top ten pulp and paper producers by 2000 (Dauvergne 1997). By 2005, there were 10 integrated pulpand-paper operations and another three nonintegrated industries (only the mills), with annual processing capacity of not less than 6 million tons (Eriantono 2010).

The development of timber plantations was made possible by the aforementioned TGHK and RTRWP. Lacking sufficient capital, expansion of timber plantations was supported with loans from both the WB and Asian Development Bank and amounted to US\$ 15 billion (Gellert 2005, 2010). The government designated production forests that have been abandoned by logging concessions as "unproductive" forest and thus eligible for conversion to timber plantations (Kartodiharjo and Supriono 2000). Forests with $<16 \mathrm{~m}^{3} /$ ha of commercial timber were classified as unproductive (Potter and Lee 1998). Until 2002, nearly 5 million ha of forestland, mostly in Sumatra, were categorized as unproductive and designated for HTI (Maturana 2005). In addition to logged-over production forests, plantations could be established in jungle rubber stands, swamp forests, and natural grasslands (Potter and Lee 1998, Maturana 2005). Both new companies and natural forest concession holders were invited to make investments in tree plantation schemes (Kartodiharjo and Supriono 2000).

In the process of pulpwood plantation establishment, concessions were allowed to harvest (clear cut) and sell all the timber regardless of tree size or species from the areas designated for conversion. As of 2011, 249 pulp plantation permits covering about 10 million ha were issued (MoF 2012), but actual plantation establishment lagged far behind in the designated areas. According to official statistics, by 2011 the cumulative area of timber plantations reached 5.4 million hectares (MoF 2012). However, any figure needs to be treated with caution because large areas were never fully stocked and were poorly managed (Barr et al. 2010). The low planting level is principally explained by the interests of the plantation companies to obtain raw materials from the clear cuts in natural forests than from plantations thus exacerbating primary forest loss (Gellert 2005, Barr and Sayer 2012). 


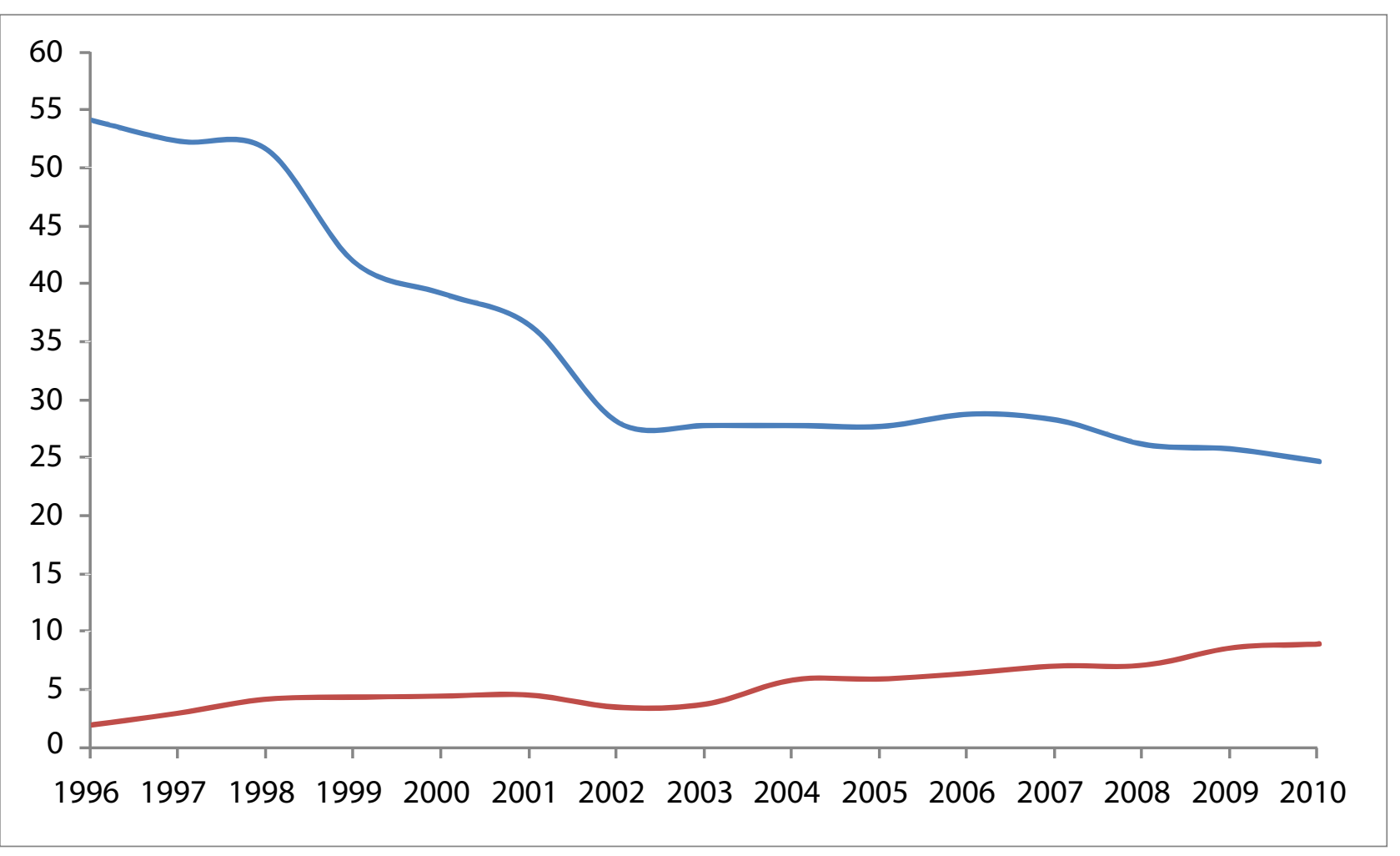

Figure 2.3. Trends in total area of natural forest vs. timber plantation concessions ( $y$ axis in million ha; source: MoF 2012).

As in logging concessions, HTI schemes provided windfall profits from timber sales from once forested land. Apparently many HTI concessionaires were mainly interested in the right to clear-cut and sell the timber, rather than in the potential long-term benefits from conversion of logged-over forest into plantations (Resosudarmo et al. 2012). Worse yet, many of the areas classified as "unproductive forests" were in fact well-stocked with commercial timber. Another similarity with logging concessions is that many of the companies given HTI licenses members of President Soeharto's family and their cronies (Dauvergne 1997). For the privilege of plantation conversions, HTI licenses were required to pay only nominal fees for the harvested wood because the levies for pulpwood were set at rates well below stumpage value, only US $\$ 2 / \mathrm{m}^{3}$ (Barr and Sayer 2012). They also benefitted from the good wood which was used for sawn-wood (Kartodiharjo and Supriono 2000). It is argued, therefore, the forest resources were sold by the MoF to the plantation companies for a price below their true value (Maturana 2005).

Plantation concessions also received large incentives in the form of interest-free loans provided from DR as well as low-concession land taxes (Kartodiharjo and Supriono 2000, Resosudarmo et al. 2012). Regulated by Forest Ministerial Decree No. 752/
Kpts-II/1990, HTIs were run as joint ventures between the government and private companies with $14 \%$ of the funds from the government, $21 \%$ from the private company, $32.5 \%$ from interestfree DR loans, and 32.5\% from commercial DR loans ${ }^{4}$. Between 1997 and 1998, US\$417 million from the DR fund was used to finance plantation development in the form of cash grants and discounted loans; many recipients either overestimated their establishment costs or over-stated the areas planted (Barr 2007). Furthermore, many plantation concessions used interest-free DR loans for purposes other than tree planting such as real estate/ properties and mining, or just placed them in time deposits to earn interests (Dauvergne 1997, Christanty and Atje 2000, Barr et al. 2010).

\subsubsection{Forest operations and silvicultural systems}

Along with the rapid growth of vertically integrated forest industries, vast numbers of workers of various types were employed at various levels (Strehlke 1993). It is hard to estimate with accuracy the number of forest workers in Indonesia, but during

4 Biannually set by MoF according to the interest rates of time deposits. 
the timber boom from five hundred thousand to one million direct workers were employed, with more millions thought to have been indirectly involved (Hasan 1991, Strehlke 1993). Despite the decline of the forest industries, a forecast from MoF suggests that until 2020 direct employment generated in the forest sectors is expected from 675,000 to 836,000 jobs due to the expanding commercial timber plantations (ILO 2010).

When commercial logging started in Indonesia in the late 1960s, many logging concessions employed foreign managers (Gillis 1998). The concessions were logged intensively but they otherwise followed good standards for logging operations and occupational, safety, and health issues (OSC). With the departure of foreign companies in the 1970s, many forest operations were characterized by insufficiently trained workers with poor working conditions and OSC standards (Strehlke 1993, Elias 1998, Gandaseca et al. 1998, Gandaseca and Yoshimura 2001, ILO 2010). These conditions, combined with poor planning of harvest operations and lack of silvicultural treatments, resulted in excessive damage to, and depletion of, forest resources (Abdulhadi et al. 1981, Bertault and Sist 1997, Elias 1998, Putz et al. 2000).

As said earlier, forest operations in natural forests were implemented according to the governmentprescribed silvicultural systems of TPI and later TPTI. Both systems rest on three main concepts: the cutting cycle, the harvest diameter limits, and the commercial young trees left for the future harvests (Yasman 198, Sist et al. 2003a, b, Rimbananto 2006, Wahyudi 2011). The systems set the cutting cycle at 35 years so concessions were divided into 35 annual coupes. The cutting cycle is actually longer than the duration of the concession which is set to 20 years. Minimum felling diameters were set at $50 \mathrm{~cm}$ and $60 \mathrm{~cm}$ for production forest and "limited-production forests" respectively ${ }^{5}$. The systems further specified the diameter of commercial young trees that had to be left in the forests for the future harvest cycles of more than 25 stems/ha. Those requirements were based on the assumption of an annual diameter growth of commercial trees of at least

5 Determined through scoring based on three criteria: terrain, precipitation (rain intensity) and soil types (erodibility). In general, production areas with extreme terrain, fragile and sensitive soil, and high precipitation categorized as "limited production forests". one cm (Yasman 1998, Wahyudi 2011). In fact, the diameter limits only accommodate processing technologies and market demands, rather than the biology of the harvested species (Sist et al. 2003a, b).

Prior to commencing logging operations, concessions are obliged to craft a long-term (10-year) management plan based on a $1 \%$ effort inventory of trees $\geq 20 \mathrm{~cm} \mathrm{DBH}$ in the entire concession area to determine the annual allowable cuts. More detailed annual plans based on $100 \%$ effort of harvestable trees are required prior to logging in each annual coupe. In practice, accurate pre-logging inventories of either sort were rarely undertaken so that the harvest plans were often unsatisfactory (Sist et al. 2003b, Rimbananto 2006). Motivated by increasing demands for logs and attractive profits, many concessions were often tempted to cut as much timber as possible during their 20-year license, often including timber from outside the assigned annual coupes (Gillis 1988, Kasa 1999). This practice was made possible by the MoF's poor and idiosyncratic monitoring procedures (Dauvergne 1997). To hide unauthorized harvests, the concessions often set their annual allowable cuts higher than their actual timber stocks (Kartawinata et al. 2001, Barr and Sayer 2012). The common practice of reharvesting recently-cut stands to get trees for which markets developed over the intervening years led to further forest degradation (Gillis 1988, Kasa 1999, Kartawinata et al. 2001).

The silvicultural system based exclusively on diameter limits also contributed to excessive damage in the forest ecosystems including on the reproductive trees and the advanced regeneration (Sist et al. 2003a). Concessions tended to cut as many large trees as long as they met the cutting limits. The number of trees harvested was significantly high, more than 10 trees per ha damaging in this way more than $50 \%$ of the original stand (Abdulhadi et al. 1981, Bertault and Sist 1997, Elias 1998, Sist et al. 1998). In addition, a high degree of damage on the residual stands limited tree survival (Elias 1996), further facilitated by poor planning, improper operational practices, and lack of control and supervision of crews (Elias 1998).

By the end of the 1980s, many production forests were severely over-logged and otherwise degraded (Dauvergne 1997). Starting in 2005, a number of efforts were made to modify the silvicultural system with the core objective of increasing timber production. Radical policy changes included: 1) reduction of minimum cutting diameters by 10 
$\mathrm{cm}$ respectively for both production and limited production forests, 2) reduction of the minimum cutting cycle by 5 years; and, 3) required planting of commercial species along cleared lines (Wahyudi 2011). Guided in the Decision of Director General of Forest Production Management (BPK) No. 226/ VI-BPHA/2005, revised in P.9/VI/BPHA/2009, the distance between cleared lines is set at $20 \mathrm{~m}$, with the spacing between seedlings of $3 \mathrm{~m}$. It was expected that approximately 160-200 trees $>40$ $\mathrm{cm} \mathrm{DBH}$ would be harvestable from each hectare at the end of the 25-year rotation (Naiem and Faridah 2006, Wahyudi 2011).

This new system, locally referred to Silvikultur Intensif(SILIN), was initially trialed in six large concessions in Kalimantan (Naiem and Faridah 2006), three of which were already FSCcertified (Subiakto 2006). SILIN has since been implemented in at least 25 other concessions (Kusmana 2011, Prasetyo et al. 2012) but is to be implemented widely, including in communitybased smallholder schemes (Obidzinski and Dermawan 2010). Where properly tended, the planted trees grow rapidly (Pamoengkas 2010, Widiyatno et al. 2011), which raises concerns about the biodiversity impacts of SILIN when those trees are harvested. Although only $15 \%$ of the forest is cleared for tree planting (Obidzinski 2010) the expected harvest rate exceeds the maximum recommended (Sist et al. 2003b) by a full order of magnitude.

In contrast to the management intensification required by SILIN, most researchers call for more gentle forest treatments to secure sustainability. At the core of these recommendations is the implementation of reduced-impact-logging (RIL) techniques, but with limits on harvest intensities and minimum distances between harvested trees (Sist et al. 2003a). These approaches increase the survival of trees that will provide the next harvest and minimize the deleterious environmental impacts of logging (Bertault and Sist 1997, Sist et al.1998).

\subsection{Forest certification in Indonesia}

Certification emerged in the 1990s as a response to the irresponsible management of natural forests in Indonesia and elsewhere in the tropics. Partly driven by the growing skepticism about the effectiveness of governmental initiatives and the perceived failures of global intergovernmental mechanisms to stop forest degradation and deforestation, a number of leading environmental groups saw the threat of boycotts of tropical timber as a way to motivate a market-based mechanism to improve forest practices (Ottman 1998). Certification promotes responsible forest management by soliciting the support of consumers to purchase forest products that have been assessed against a set of forest management standards agreed upon through independent participatory processes (Rametsteiner 2002, Cashore et al. 2004, Durst et al. 2006). In contrast to boycotts of timber products, this policy instrument provides a softer approach through the use of market leverages of premium prices and increased market access for certified forest products.

\subsubsection{Institutional dynamics}

The Indonesian timber sector, as revealed in the previous sections, has been characterized heavily by irresponsible forest management featuring rampant and destructive logging, inefficient timber utilization, poor workers' rights, poor/ absence monitoring, abuses of forest regulations, biodiversity loss, overlapping forest land-use and marginalisation of customary practices. The genesis of Forest Stewardship Council (FSC) with its principles and criteria that strongly address those issues was considered by MoF and the business people to potentially have reverse impacts on the country's lucrative forest sector (Elliot 2000). Thus, the government actively sought ways to influence the dynamics of the market mechanism. Rather than participate in FSC certification, the government preferred the establishment of a national program. The powerful business groups understandably wanted to take the lead in the initiative (Elliott 2000: 99). They established a commission to develop national standards for sustainable forest management - mostly based on the ITTO criteria and indicators - and aspired to use them as a mandatory approach for forest concessions in Indonesia (Hasan 1992).

Interestingly, MoF declined their initiative and instead appointed Emil Salim - then the minister of environment who was well-connected to, and respected by, environmental groups - to chair a working group for the national program in 1993 (Elliott 2000). It is argued that the government control in the eventual certification program could 
still be ensured through the appointment of the minister (Elliott 2000), while his close connection to environmental groups meant to ease off the increasing pressure on irresponsible management of the country's forests (Maryudi 2005). The working group for the national certification program however, aspired for greater autonomy from the government and it held intensive discussions with the FSC over the possibility of the eventual program as an FSC's national initiative. It decided to establish an independent certification program, named The Indonesian Ecolabel Institute (Lembaga Ekolabel Indonesia/ LEI). The national program initially had more flexible standards and was otherwise in stern opposition to FSC (see Elliott 2000, Purbawiyatna et al. 2004, Muhtaman and Prasetyo 2006). The aforementioned political dynamics of an authoritarian regime coupled with the strong influence of business groups that remained as an important component of the certification program help to explain the initially hostile response to the FSC (Maryudi 2005).

By the end of the 1990s, the more democratic polity in Indonesia, followed by the steadily increasing influence of environmental and socialwelfare groups (Gellert 2010) generated a generally more positive response to the FSC and forest certification. In 1999, FSC and LEI agreed to carry out a joint certification protocol (JCP) in which FSC-accredited certification bodies (CBs) work with LEI-accredited CBs to issue certificates by both certifiers (van Assen 2005). This working model was possible after harmonization of certification standards. LEI raised its standards and audit procedures to an extent acceptable by the FSC, which on the other hand relaxed some of its requirements (Maryudi 2005, Davenport et al. 2010). For example, to facilitate certification of natural forest concessions, in 1998 FSC changed the wording of its Principle 9 on "primary forests" to focus instead on forests with "High Conservation Values" (Gale 2006).

In 2001, the first natural forest concession was certified under the JCP. This accomplishment was expected to provide a solid platform for widespread adoption of forest certification by natural forest concessions in Indonesia (van Assen 2005). Instead, the certification drew criticisms regarding lack of full compliance with the standards (see Arbi and Counsel 2002, Colchester 2002). Being certified, the company became more vulnerable to negative exposure. It was argued that this exposure, combined with limited financial benefits from certification, dampened enthusiasm of other concessions towards certification (Maryudi 2009). In 2005, after 5 natural forest concessions with a combined area of about 1 million ha were certified (Prasetyo et al. 2012), the joint program was terminated (Maryudi 2009). FSC and LEI concluded that the program did not produce the expected outcome of increased participation by Indonesian forest concessions and decided to continue with certification efforts independently (Davenport et al. 2010).

The termination of JCP was due to various accounts. From practical perspectives, JCP incurred double costs for interested companies as it followed two different assessments from both LEI and JCP. In part, this explains the limited interests from forest concessions. In addition, expectations were not fulfilled that the LEI could have benefited from FSC's international channels (Maryudi 2005). LEI also felt that it remained under FSC's shadow instead of sharing equal positions between the two programs. More importantly, LEI appeared to be discontent with FSC's policy to not certify plantations that involved conversions of natural forests post1994. While affiliation to another international program - the Programme for the Endorsement of Forest Certification (PEFC) - was largely opposed particularly from environmental and social groups the national program eventually decided to provide independent certification.

PEFC itself recently considered commencing operations in Indonesia. PEFC has approved the application from the Indonesian Forestry Certification Cooperation (Kerjasama Sertifikasi Kehutanan Indonesia/ KSKI) ${ }^{6}$ as a national governing body member of the PEFC Council, and has invested substantially in standard settings and public consultation. For PEFC, aparently, the Cooperation is driven by interests to capture opportunities on certification of plantation which are presently outside FSC's coverage. The lion share of the the existing timber plantations was established post-1994. Williams (2001) point out that as of December 2005, the establishment of timber plantations in Indonesia reached just about half a million hectares. In announcing the Cooperation, the program in fact highlights the importance of Indonesias pulp and paper producers (see PEFC 2013). On the other hand, the Cooperation is also

6 KSKI: new certification scheme established in 2011 promoted and led by a LEI-former executive director 
expected to facilitate the interests of Indonesia's pulp industries on securing domestic supply of certified raw materials (Bisnis Online 2014). While support for LEI has apparently diminished, forest certification in the country could become a twohorse race between FSC and PEFC.

\subsubsection{Emerging incentives for responsible forest management}

Apart from the five JCP-certified concessions, no other natural forest concessions were certified by 2007 . This can be explained by a number of constraints including wide gaps between existing management standards and certification requirements, lack of funds, conflicting policy and legal frameworks, weak ability to ensure effective implementation of forest policies, and a lack of confidence in the business case for certification (Durst et al. 2006, Profor 2012). Indonesia's exports of timber products to environmentally sensitive destinations (e.g., European Union and Japan) are low (Box 2.1), which reduces the incentives to go to the trouble and expense of forest certification (Profor 2012).

Proponents of forest certification argue that given the wide gap between existing forest practices applied and what is needed to meet certification requirements, standards should be lowered to render them more realistic and hence draw interest (Bleaney 2010, Ruslandi et al. 2014). Recently, efforts focus on building concessionaire's confidence in certification by directly linking them with markets of certified products, and by improving forest management practices (Profor 2012, TNC 2012, TBI 2012). A number of agencies are actively involved in assisting forest concessions to this end including for instance, the Tropical Forest Trust (TFT) ${ }^{7}$. The largest certification-promoting initiative is The Borneo Initiative (TBI). TBI provides a platform to forge partnerships between various environmental NGOs, standard setting and certifying bodies, government, forest concessions, and overseas timber trading companies (Box 2.1).

In 2012, thirty one concessions covering $>3$ million ha were participating in the initiative, some of which became FSC certified (TBI 2012). TBI set the targets of 5 million ha certified by the end of 2014 and 9 million in 2016 (TBI 2012).

7 In 2010 renamed into The Forest Trust (also TFT)
The 2016 target constitutes approximately a third of the total area of Indonesia's natural production forests managed by concessions. FSC certification is generally preferred over LEI in Indonesia due to the former's global recognition from which there are expected financial benefits (premium prices and increased market access). Presumably for these reasons, some LEI-certified management units later applied and successfully gained FSC certification ${ }^{8}$.

One account explaining the enthusiasm of external agencies on assisting forest concessions relates to the creation of business models of tropical timber trade arising from responsible operations (TBI 2012, Ruslandi et al. 2014). Along with improved corporate reputations and market access, external funding and technical support seem to be the major motivating factors for engaging in forest certification (Ruslandi et al. 2014). This is quite important since the market benefits from price premiums remains limited. Growing interest in forest certification has drawn notice from a number of institutions. A number of FSC-accredited certification bodies have opened their offices in Indonesia (Appendix I) at least partially in response to the large and growing number of concessions working with TBI.

The steady increase of total forest area under certification (Table 2.5) indeed indicates signals on improved forest management since certification follow a rigorous assessment procedure against a set of standards. It nonetheless remains important to see the direct impacts of certification on the ground. It is claimed that field-based evaluations of the impacts of forest certification are substantial (Gale 2006, Muhtaman and Prasetyo 2006). A recent study (Ruslandi et al. 2014) on five FSC-certified forest concessions finds that forest management certification improves: i) logging practices, principally through the implementation of RIL, ii) biodiversity conservation and environmental protection, and iii) relations between concessions and local communities. The study further points out social and environmental management and monitoring plans and procedures, which are often absent in non-certified concessions. Griscom et al. (2014) attempted to link RIL implementation with carbon emissions performance of FSC-certified concessions.

8 The case of a group of smallholding tree grower in Wonogiri, Central Java. 


\section{Box 2.1. The Borneo Initiative (TBI)}

\section{Indonesian timber export values by destinations (in millions of US\$) for January-August 2013}

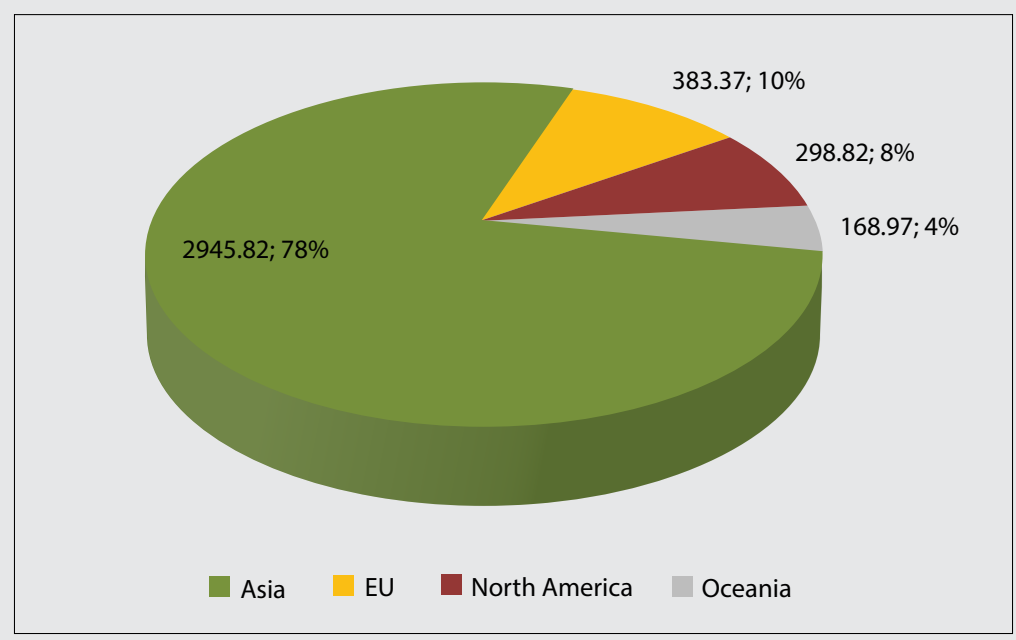

Source: Ministry of Forestry cited in MFP 2013

The Borneo Initiative (TBI), established in 2008 by WWF, FSC-Netherlands, and Dutch housing associations, is supported by several Dutch institutional and corporate donors as well as by housing corporations funds. TBI is designed to link Dutch demand for FSC-certified forest products with supply from Indonesian Borneo (Kalimantan) and recently Malaysia and Papua New Guinea. In 2013, TBI signed a memorandum of understanding with the Indonesian Association of Forest Concessionaires (APHI), the Worldwide Fund for Nature (WWF), certification coaching organizations (e.g., TFT, TFF, TNC, and the Global Forest Trade Network), standard-setting bodies (e.g., MoF and FSC), forest concessions, and overseas timber trading companies.

To cover up to half the costs of obtaining FSC certification, TBI will provide concessions with a subsidy of US $\$ 2 /$ ha, with a maximum of US $\$ 300,000$ per FMU. A higher subsidy of US $\$ 3 /$ ha is available for forest concessions of only $35,000-75,000$ ha, with a ceiling subsidy of US\$150,000. To qualify for TBI funding, concessions with $<35,000$ ha are encouraged to link up with other small concessions to meet that minimum size criterion. The subsidy can be used to pay certification costs including those needed to improve management practices, for certification audits, or for both. Through the certification coaching institutions, TBI provides assistance on a variety of cross-cutting issues such as biodiversity management, high conservation value forests, reduced-impact logging, and chain-of-custody. Forest concessions are free to choose from among the TBI-approved coaching institutions.

Source: TBI 2012

Table 2.5. Extent of FSC and LEI certification in Indonesia (accessed from FSC and LEI websites on 5 December 2013).

\begin{tabular}{lcccc}
\hline Types of Areas Certified & \multicolumn{3}{c}{ FSC } & \multicolumn{2}{c}{ LEI } \\
\cline { 2 - 5 } & $\begin{array}{c}\text { Number of } \\
\text { Certificates }\end{array}$ & Area (ha) & $\begin{array}{c}\text { Number of } \\
\text { Certificates }\end{array}$ & Area (ha) \\
\hline Natural forests* & 14 & $1,528,932.60$ & 6 & $1,102,052.00$ \\
Plantations & 7 & $198,376.64$ & 3 & $1,429,055.00$ \\
Community forests/ SLIMF & 17 & $2,855.06$ & & $32,683.00$ \\
Chain of custody & 190 & - & 6 & - \\
\hline
\end{tabular}

* 5 concessions covering just over 800000 ha are certified by both FSC and LEl (initially under FSC-LEl's JCP) 


\subsubsection{Synergies with other mechanisms}

In recent years, another trade related mechanism has emerged which can complement forest certification in promoting improved forest management. In response to global concerns about illegal logging and its associated trade, the European Union (EU) launched an initiative on Forest Law Enforcement, Governance and Trade (FLEGT). The core component of this initiative is the development of voluntary partnership agreements (VPAs) with timber-producing countries that wish to eliminate illegal timber from their trade with the EU (Cashore and Stone 2012). Indonesia embarked on negotiations for a VPA with the EU in September 2013. Central to the VPA is the Indonesian timber legality assurance system (Sistem Verifikasi Legalitas Kayul SVLK), key components of which resemble forest certification. SVLK has a narrow focus on the legal aspects of timber, similar to a chain of custody mechanism. Nonetheless, SVLK has far reaching goals of improving forest governance. Following the signing of the VPA and the anticipated ratification by EU and Indonesia, only timber with a Timber Legality Assurance System certificate (TLAS) will be allowed to enter EU markets.

\subsubsection{Key challenges}

Despite some progress on voluntary third-party forest certification in Indonesia, a number of key challenges remain. Tenure security poses a huge impediment to forest certification. Conflicting regulatory frameworks, principally those related to customary forests, combined with the diversity of institutions that deal with land allocation, impinge on the areas currently managed by forest concessions. Many areas within State Forests, including those allocated for timber concessions, are claimed to have been inhabited by local communities and should therefore be subject to customary rules (Li 2001). Even long before the recognition of customary forests, tenure conflicts between concessions and local communities characterized forest utilization and management in Indonesia (Li 2001, Yasmi et al. 2005). The aforementioned criticisms of the FSC-LEI joint certification of PT DRT were partly explained by the company's persistent conflicts with local communities (Arbi and Counsel 2002, Colchester 2002).
Improved forest operations, especially implementation of RIL are key to the success of certification as a conservation intervention (Bleaney 2010). Although not explicitly linked to certification, key elements of RIL system constitute a substantial step toward sustainability and support a number of the requirements for forest concessions to become certified (Putz et al. 2000, Bleaney 2010). Implementation of SILIN appears to contradict FSC principles, especially the requirement to clear planting lines through the forest, to plant 200 timber trees per hectare, and to increase the intensity of harvests. To the extent that implementation of SILIN represents forest conversion into plantations, forests in which it is applied should not be eligible for FSC certification. Although only $15 \%$ of the forest is actually cleared, the anticipated harvest of 160 trees per hectare after only 25 years will be devastating to biodiversity but might provide a great deal of timber to the industry at costs that need to be determined.

\subsection{Conclusions}

Policies and processes of forestland allocation in Indonesia have been dominated by a strong development paradigm that emphasized largescale exploitation of forest resources with further conversion of once-forested lands to other uses. As Barr and Sayer (2012) note, the country's timber sector has been characterized by a strong affiliation of a few individuals from the business sector loyal to forest power holders in the government, which together solidified their positions in the country's political economy hierarchy. The business people enjoyed preferential forest policies that allowed them to secure fantastic short-term economic profits from unsustainable use of the country's forestland. Forest concessions and timber industries were developed accordingly to policies that served to undervalue forests. Along with insufficient monitoring mechanisms, preferential policies encouraged concession holders to employ rampant and destructive logging operations. Policies that favored industrial plantations further facilitated rapid conversion of biodiversity-rich natural forests into other uses.

Forest certification is widely promoted to encourage responsible forest management through the appeals of market incentives. Unfortunately, 
certification in Indonesia faced a hostile response from both the forest industry and the government and its progress has been hampered by a number of factors at various scales (Gale 2006). At the national level, despite concrete commitments by the government to promote the wise use of forests, many of its policies conflict with the goals of sustainable forestry. This bleak situation was not aided by the limited signals of economic benefits arising from certification associated to the high costs of improved forest management.

Recent efforts by a number of donor agencies and NGOs have contributed to a steady rise in the adoption of certification as a market instrument in Indonesia. Nonetheless, key challenges remain. At the macro level, harmonization of policies coupled with institutional clarity and coordination are needed with regard to land uses and allocation. Delays in policy harmonization may hold up potential candidates for certification, and may even affect currently certified concessions. At the level of MFUs, the intensification of silvicultural management required by SILIN may prove to be a big threat to certification if it is shown to have large deleterious impacts on biodiversity and forest function.

Two certification schemes currently operate in Indonesia (LEI and FSC) but a third is about to start (PEFC). Over the years, there have been political dynamics related to LEI and FSC support in supply chains and markets and a brief period of consolidated efforts. The two schemes now certify forests independently, but the effectiveness of LEI has diminished. In the foreseeable future, PEFC stands to enliven the dynamics of forest certification in Indonesia once again. Uptake of PEFC certification will depend on a number of factors including the perceptions of Indonesian forest and industry managers and market conditions. With the exception of timber plantations, FSC seems to have a more solid foundation given its stronger acceptance in the key markets for Indonesian timber products.

The FLEGT-TLAS mechanism also suggests that legality verification may facilitate forest management certification. Insofar as legality verification is mandated by the government, this scheme will become the priority of forest managers in Indonesia but this could be a transitional phase if managers realize that by establishing their legality, they are well on the way towards certification. In contrast, if key markets for Indonesia timber products are satisfied with legality verification, and do not push for management certification, then enthusiasm for certification may decline.

\subsection{References}

Abdulhadi R, Kartawinata K and Sukardjo S. 1981. Effects on mechanized logging in the lowland dipterocarp forest at Lempake, East Kalimantan. Malaysian Forestry. 44, 407-418.

Adam C and Dercon S. 2009. The political economy of development: an assessment. Oxford Review of Economic Policy, 25 (2): 173-189.

Ahmad M and Ramli R. 1991. Rente ekonomi dalam pengelolaan hutan alam, WALHI. Jakarta, Indonesia.

Arbi V and Counsell S. 2002. PT. Diamond Raya Timber, Indonesia Case Study 9. In: S. Counsell and K. Loraas eds. Trading in Credibility: The Myth and Reality of the Forest Stewardship Council. Rainforest Foundation UK. pp. 136-143.

Atje R and Roesad K. 2004. Who should own Indonesia's forests? Exploring the links between economic incentives, property rights and sustainable forest management. CSIS Working Paper Series. WPE 076. Centre for Strategic and International Studies (CSIS), Jakarta.

Barr C. 2002. Questioning the Assumptions of the "Sustainable Logging". In: Colfer C. J. P. and Resosudarmo, I.A. P. eds. Which Way Forward? Forests, Policy and People in Indonesia. Resources for the Future, Washington D. C. pp. 191-220.

Barr CM. 1998. Bob Hasan, the rise of Apkindo, and the shifting dynamics of control in Indonesia's timber sector. Indonesia, 65 (April): 1-38.

Barr CM. and Sayer, J.A. 2012. The political economy of reforestation and forest restoration in Asia-Pacific: Critical issues for REDD+. Biological Conservation, 154: 9-19.

Barr C, Dermawan A, Purnomo H and Komarudin H. 2010. Financial governance and Indonesia's Reforestation Fund during the Soeharto and post-Soeharto periods, 1989-2009: a political economic analysis of lessons for REDD+. Occasional Paper No. 52. CIFOR, Bogor, Indonesia. 
Barr C, Resosudarmo IAP, Dermawan A and McCarthy J. 2006. Decentralization of Forest Administration in Indonesia: Implications for Forest Sustainability, Economic Development and Community Livelihoods. Center for International Forestry Research, Bogor, Indonesia.

Bernstein S, Cashore B, Atyi RE, Maryudi A, McGinley K, Cadman T, Gulbrandsen L, Goehler D, Hogl K, Humphreys et al. 2010. Examination of the influences of global forest governance arrangements at the domestic level. In: Rayner et al. eds. Embracing complexity: Meeting the challenges of international forest governance, International Union of Forest Research Organizations (IUFRO).

Bertault JG and Sist P. 1997. An experimental comparison of different harvesting intensities with reduced-impact and conventional logging in East Kalimantan, Indonesia. Forest Ecology Management, 94: 209-218.

Bisnis Online 2004. Industri Kehutanan: Diberlakukan Sertifikasi Standar PEFC. Available from:http://m.bisnis.com/industril read/20140508/99/225825/industri-kehutanandiberlakukan-sertifikasi-standar-pefc (Accessed 13 May 2014).

Bleaney A. 2010. Certification in Indonesia: a practitioner perspective. ETFRN News, 51: 65-71.

Brattskar H. 2011. Safeguarding the world's forests: Indonesia's promising future. BioRes Trade and Environment, 5 (2): 6-7.

Brockhaus M, Obidzinski K, Dermawan A, Laumonier Y and Lutrell C. 2012. An overview of forest and land allocation policies in Indonesia: Is the current framework sufficient to meet the needs of REDD+? Forest Policy and Economics, 18: 30-37.

Brown DW. 1999. Addicted to Rent. DFID/ITFMP Report, 7 September 1999.

Burgess R, Hansen, M., Olken, B.A., Potapov, P. and Sieber, S. 2012. The Political Economy of Deforestation in the Tropics. The Quarterly Journal of Economics, pp. 1-39.

Cashore B and Stone M. W. 2012. Can legality verification rescue global forest governance? Analyzing the potential of public and private policy intersection to ameliorate forest challenges in Southeast Asia. Forest Policy and Economics, 18 (5): 13-22.

Cashore B, Auld G and Newsom, D. 2004. Governing Through Markets: Forest certification and the emergence of non-state authority. Yale University Press, New Haven.

Casson A. 2001. Decentralisation of Policies Affecting Forests and Estate Crops in Kutai Barat District, East Kalimantan. Case Study 4 on Decentralization and Forests in Indonesia. CIFOR, Bogor, Indonesia.

Christanty L and Atje R. 2004. Policy and Regulatory Developments in the Forestry Sector Since 1967. CSIS Working Paper Series. WPE 077. Centre for Strategic andInternational Studies (CSIS), Jakarta

Contreras-Hermosilla A and Fay C. 2005. Strengthening Forest Management in Indonesia through Land Tenure Reform: Issues and Framework for Action. Fores Trends and World Agroforestry Centre

Colchester M. 2002. Bridging the Gap: Challenges to Community Forestry Networking in Indonesia. Learning from International Community Forestry Networks: Indonesia Country Study.

Coleman EA. 2009. Institutional Factors Affecting Biophysical Outcomes in Forest Management. Journal of Policy Analysis and Management, 28 (1):122-146.

Cubbage F, Harou P and Sills E. 2007. Policy instruments to enhance multi-functional forest management, Forest Policy and Economics, 9: 833-851.

Dauvergne P. 1997. Shadows in the Forest: Japan and the politics of timber in Southeast Asia. MIT Press, Cambridge.

Dauvergne P. 1998. The political economy of Indonesia's 1997 forest fires. Australian Journal of International Affairs, 52 (1): 13-17.

Davenport D, Bulkan J, Hajjar R, Hardcastle P, Assembe-Mvondo S, Atyi RE, Humphreys D and Maryudi A. 2010. Forest and Sustainability. In: Rayner, J., Buck, A. and Katila, P eds. Embracing complexity: Meeting the challenges of international forest governance. International Union of Forest Research Organizations (IUFRO), pp. 75-92.

de Camino R. 2005. Forest management and development. In: Burger, D., Hess, J. and Lang, B. (Eds.) Forest Certification: An innovative instrument in the service of sustainable development? Deutsche Gesellschaft für Technische Zusammenarbeit (GTZ) GmbH, Eschborn, Germany.

Dermawan A, Komarudin H and McGrath S. 2006. Decentralization in Indonesia's forestry 
sector -Is it over? What comes next? Paper at the Eleventh Biennial Global Conference of The International Association for the Study of Common Property (IASCP), 19-23 June 2006, Bali.

Durst P, McKenzie PJ, Brown CL and Appanah S. 2006. Challenges facing certification and eco-labelling of forest products in developing countries. International Forestry Review, 8(2): 193-200

Elias. 1996. Stand Damage and Regeneration in Forest Concession Areas of Pt. Kiani Lestari and PT. Narkata Rimba, East Kalimantan, Indonesia. Paper presented at CIFOR International Research Training Seminar on Reduced Impact Wood Harvesting and Natural Forest Management in Bogor and Balikpapan, Indonesia. 15-27 July 1996.

Elias. 1998. Reduced impact timber harvesting in the tropical natural forest in Indonesia. Forest Harvesting Case-Study 11. Food and Agriculture Organization of the United nations, Rome.

Elliott C. 2000. Forest Certification: A Policy Perspective. Center for International Forestry Research, Bogor.

Eriantono D. 2010. Private sector financing in Indonesian forestry - removing constraints to investments. In: Pescott M, Durst P and Leslie RN. eds. Growing Green Assets: Removing constraints to private sector investment in forestry in Asia and the Pacific. RAP Publication 2010/ 18. Food and Agriculture Organization of the United Nations, Regional Office for Asia and the Pacific, Bangkok.

Gale F. 2006. The Political Economy of Sustainable Development: Lessons the Forest Stewardship Council Experience. Refereed paper presented to the Second Oceanic Conference on International Studies University of Melbourne, 5-7 July 2006.

Gandaseca S and Yoshimura T. 2001. Occupational Safety, Health and Living Conditions of Forestry Workers in Indonesia. Journal of Forest Resource, 6:281-285

Gandaseca S, Yoshimura T, Yamamoto T and Mulyono S. 1998. A Biomechanical Analysis of Industrial Forest Plantation Workers in East Kalimantan, Journal of Forest Resource, 3:75-78.

Gellert PK. 2003. Renegotiating a Timber Commodity Chain: Lessons from Indonesia on the Political Construction of Global
Commodity Chains. Sociological Forum, 18

(1): 53-84.

Gellert PK. 2005. The Shifting Natures of

"Development": Growth, Crisis, and Recovery

in Indonesia's Forests. World Development, 33

(8): 1345-1364.

Gellert PK. 2010. Rival Transnational Networks, Domestic Politics and Indonesian Timber, Journal of Contemporary Asia, 40 (4): 539-567.

Gillis M. 1988. Indonesia: Public policies, resource management, and the tropical forest. In: Public Policies and the Misuse of Forest Resources. Repetto, R. and Gillis, M. eds. Cambridge University Press, New York. 43-114.

Gillis M. 1992. Forest concession management and revenue policies. In Sharma, N.P. ed. Managing the world's forests. Kendall-Hunt, Dubuque, Iowa. 139-175

Greenomics. 2004a. Evolusi Mekanisme Perizinan Usaha Pemanfaatan Hasil Hutan Kayu pada Hutan Alam dan Hutan Tanaman. Kertas Kerja No. 6. Jakarta, Indonesia.

Greenomics. 2004b. Pungutan Usaha Kayu: Evolusi terhadap Mekanisme Perhitungan, Pemungutan dan Penggunaan Pungutan Usaha Kayu. Kertas Kerja No. 7. Jakarta, Indonesia.

Griscom B, Ellis P and Putz FE. 2014. Carbon emissions performance of commercial logging in East Kalimantan, Indonesia. Global Change Biology, 20(3):923-937.

Hasan M. 1991. The Indonesian wood panel industry. Unasylva, 42 (4): 11-15.

Hasan M. 1992. The Future Role of Dipterocarps in Indonesian Forestry: Industry's viewpoint. Paper presented at an Indonesian Forestry Community seminar, Balikpapan, November 1992.

Hansen MC, Potapov PV, Moore R, Hancher, Turubanova SA, Tyukavina A, Thau D, Stehman S V, Goetz SJ, Loveland et al. 2013. High-Resolution Global Maps of 21stCentury Forest Cover Change. Science, 342: 850-853.

Hurst P. 1990. Rainforest Politics: Ecological Destruction in Southeast Asia. Zed Books, London and New Jersey

Indrarto GB, Murharjanti P, Khatarina J, Pulungan I, Ivalerina F, Rahman J, Prana MN, Resosudarmo IAP and Muharrom E. 2012. The Context of REDD+ in Indonesia: Drivers, agents and institutions. Working Paper 92. CIFOR, Bogor, Indonesia. 
[ILO] International Labour Organization. 2010. Labour Conditions ini Forestry in Indonesia. International Labour Organization, Jakarta Office.

Kartawinata K. Riswan S, Gintings AN and Puspitojati T. 2001. An overview of postextraction secondary forests in Indonesia. Journal of Tropical Forest Science, 13(4): 621-638.

Kartodiharjo H and Supriono A. 2000. The Impact of Sectoral Development on Natural Forest Conversion and Degradation: The Case of Timber and Tree Crop Plantations in Indonesia. Occasional Paper No. 26E, Center For International Forestry Research, Bogor, Indonesia.

Kasa S. 1999. Political Power and the Indonesian Forest Concession System. World Forest Society and Environment. IUFRO.

Kato G. 2005. Forestry Sector Reform and Distributional Change of Natural Resource Rent in Indonesia, The Developing Economies, 43(1): 149-170

Krott M. 2005. Forest Policy Analysis. Spriger, Dordrecht (The Netherlands).

Kusmana C. 2011. Forest resources and forestry in Indonesia. Forest Science and Technology, 7:4, 155-160

Lang G and Chan CHW. 2006 China's impact on forests in Southeast Asia, Journal of Contemporary Asia, 36:2, 167-194

Li TM. 2001. Masyarakat Adat, Difference, and the Limits of Recognition in Indonesia's Forest Zone. Modern Asian Studies, 35 (3): 645-676

Loeffler U. 1996. Land Tenure Developments in Indonesia. Sector Project "The Importance of Land Tenure in Development Cooperation" Deutsche Gesellschaft für Technical Zusammenarbeit (GTZ), Eschborn, Germany

Lyons M. 1995. Export Marketing of Plywood from Indonesia. Food and Agriculture Organization, Rome.

Manning C. 1971. The Timber Boom With Special Reference to East Kalimantan, Bulletin of Indonesian Economic Studies, 7:3, 30-60

Maryudi A. 2011. Indonesia's forest moratorium: A decent deal for palm oil. BioRes - Trade and Environment, 5 (2): 15-16

Maryudi A. 2005. Politics within Markets: Convergence and divergence in Indonesian and Malaysian forest certification governance. School of Resources, Environment and Society, the Australian National University, Canberra.
Maryudi A. 2009. Forest certification for community-based forest management in Indonesia: Does LEI provide a credible option? Institute for Global Environmental Strategies (IGES), Japan.

Maturana J. 2005. Economic Costs and Benefits of Allocating Forest Land for Industrial Tree Plantation Development in Indonesia. Working Paper No. 30. Center For International Forestry Research, Bogor, Indonesia

McCarthy J. 2000. The Changing Regime: Forest Property and Reformasi in Indonesia. Development and Change, 31(1): 91-129

[MoF] Ministry of Forestry. 2008. Forestry Statistics of Indonesia 2007. Jakarta

[MoF] Ministry of Forestry. 2012. Forestry Statistics of Indonesia 2011. Jakarta

MoF and FAO 1990. Situation and Outlook of the Forestry Sector in Indonesia. Jakarta.

Moncrieffe J and Luttrell C. 2005. An Analytical Framework for Understanding the Political Economy of Sectors and Policy Arenas. Overseas Development Institute. London, United Kingdom.

Moniaga S. 1993. Toward Community-Based Forestry and Recognition of Adat Property Rights in the Outer Islands of Indonesia. In: Fox, J. ed. Legal Frameworks for Forest Management in Asia: Case Studies of Community/State Relations. East West Center Program on Environment, Honolulu.

Muhtaman DR and Prasetyo FA. 2006. Forest certification in Indonesia. In: Cashore, B., Gale, F.,Meidinger,E.and Newsom, D.eds. Confronting sustainability: Forest certification in developing and transitioning countries. Yale F\&ES Publication Series, Report Number 8.

[MFP] Multistakeholder Forestry Programme. 2013. SVLK: The Indonesian Credible Timber Assurance System Towards The VPA Implementation. Briefing Notes. August 2013 Edition.

Naiem M and Faridah E. 2006. Model of intensive enrichment planting (TPTII). In: Rimbananto ed. Silviculture Systems of Indonesia's Dipterocarps Forest Management: A lesson learned. Technical Report. ITTO Project PD 41/00 Rev.3 (F,M). Faculty of Forestry GMU and ITTO.pp: 25-36

Obidzinski K and Dermawan A. 2010. Smallholder Timber Plantation Development in Indonesia: What is Preventing Progress? International Forestry Review, 12(4):339-348. 
Ottman JA. 1998. Green Marketing: Opportunities for innovation. 2nd ed. NTC Business Books. Chicago.

Pamoengkas P. 2010. Potentialities of line planting technique in rehabilitation of logged over area referred to species diversity, growth and soil quality. Biodiversitas, 11 (1): 34-39

Peluso NL. 1995. Whose Woods are These? Counter-Mapping Forest Territories in Kalimantan, Indonesia. Antipode, 27 (4): 383-406

Poffenberger M. (1997). Rethinking Indonesian Forest Policy: Beyond the Timber Barons. Asian Survey, 37 (5): 453-469

Potter L and Lee J. 1998. Tree Planting in Indonesia: Trends, Impacts and Directions. Occasional Paper No. 18. Center For International Forestry Research, Bogor, Indonesia

Potter S and Badcock L. 2001. The Effects of Indonesia's Decentralisation on Forests and Estate Crops in Riau Province: Case Studies of the Original Districts of Kampar and Indragiri Hulu. Case Study $6 \& 7$ on Decentralization and Forests in Indonesia. CIFOR, Bogor, Indonesia.

Prasetyo A, Hewitt J and Chen HK. 2012. Indonesia: Scoping Baseline Information for Forest Law Enforcement, Governance and Trade. Baseline Study 7. EU FLEGT Facility

Pribadi A. 2004. Indonesia's Forest Policy and Reviews. In: Enters, T. and Leslie, R.N.: Forest Policies and Forest Policy Review. FAO Regional Office for Asia and the Pacific, Bangkok. Pp. 63-69

[PROFOR] Program on Forests. 2012. Certification, Verification and Governance in Forestry in Southeast Asia. Working Paper. Washington DC: PROFOR

[PEFC] Programme for the Endorsement of Forest Certification. 2013. Indonesian Forest Certification Scheme Open for Public Consultation. 5 December 2013. Accessed: http://www.pefc.org/news-a-media/ general-sfm-news/1411-indonesian-forestcertification-scheme-open-for-publicconsultation (13 May 2014)

Purbawiyatna A, Suntana AS, Muhtaman DR, Asycarya D, Riva WF, Dewi IS, Bayunanda A, Simanjuntak L, Sugianto Hendrawati D. et al. 2004. Memoar Satu Dekade Pergulatan Sertifikasi di Indonesia: Dari formasi ke transformasi Lembaga Ekolabel Indonesia. Pustaka LEI, Lembaga Ekolabel Indonesia, Bogor.
Putz FE, Dykstra DP and Heinrich R. 2000. Why Poor Logging Practices Persist in the Tropics. Conservation Biology, 14 (4): 951-956

Rametsteiner E. 2002. The roles of governments in forest certification-a normative analysis based on new institutional economics theories. Forest Policy and Economics, 4: 163-173.

Redclift M. 1998. Dances with wolves? Interdisciplinary research on the global environment. Global Environmental Change, 8(3): 177-182.

Resosudarmo BP, Nawir AA, Resosudarmo IAP and Subiman N. 2012. Forest Land Use Dynamics in Indonesia. Working Papers in Trade and Development. Arndt Corden Department of Economics Crawford School of Economics and Government. ANU College of Asia and the Pacific

Richards PW. 1996. The Tropical Rain Forest. Second edition. Cambridge University Press, Cambridge.

Rimbananto A. 2006. Silviculture Systems of Indonesia's Dipterocarps Forest Management: A lesson learned. Technical Report. ITTO Project PD 41/00 Rev.3 (F,M). Faculty of Forestry GMU and ITTO.

Ruslandi, Klassen A, Romero C and Putz FE. 2014. Forest Stewardship Council Certification of Natural Forest Management in Indonesia: Required Improvements, Costs, Incentives, and Barriers. In: Katila P, Galloway G, de Jong W, Pacheco P and Mery G. eds. Forests under pressure - Local responses to global issues. 255-273. IUFRO World Series Volume 32. Vienna.

Ruszicka I. 1979. Rent appropriation in Indonesian logging: East Kalimantan 1972/73-1976/77. Bulletin of Indonesian Economic Studies, 15:45-74.

Sandker M, Ruiz-Perez M. and Campbell BM. 2012. Trade-Offs Between Biodiversity Conservation and Economic Development in Five Tropical Forest Landscapes. Environmental Management, 50:633-644

Santoso H. 2003. Forest Area Rationalization in Indonesia: A Study on The Forest Resource Condition and Policy Reform. World Agroforestry Centre (ICRAF). Southeast Asia Regional Office, Bogor, Indonesia

Scotland N and Whiteman A. 1997. Economic rent in the Indonesian forest sector, volume 4: The forest concession industry. Indonesia-UK Tropical Forest Management Program, ODADFID .Report No. SMAT/EC/97/04, Jakarta, Indonesia. 
Scotland N, Fraser A and Jewell N. 1999. Roundwood supply and demand in the forestry sector in Indonesia. DFID/ITFMP Report.

Sidabutar HP. 1988. An Investigation of the Impacts of Domestic Log Processing and Log Export Restrictions on Indonesia's Export Earning from Logs. PhD Thesis. University of Washington.

Sist P, Fimbel R, Sheil D, Nasi R and Chevallier MH. 2003a. Towards sustainable management of mixed dipterocarp forests of Southeast Asia: moving beyond minimum diameter cutting limits. Environmental Conservation, 30 (4): 364-374.

Sist, P. Sheil, D., Kartawinata, K. and Priyadi, H. 2003b. Reduced-impact logging in Indonesian Borneo: some results confirming the need for new silvicultural prescriptions. Forest Ecology and Management, 179: 415-427.

Sist P, Nolan T, Bertault JG and Dykstra D. 1998. Harvesting intensity versus sustainability in Indonesia. Forest Ecology Management, 108: 251-260.

Soedomo S. 2012. Jenis Pungutan Kehutanan dari Perspektif Ekonomi Sumber Daya Alam, Jurnal Manajemen Hutan Tropika, 18 (1): 60-67

Subiakto A. 2006. Irregular flowering pattern. In: Rimbananto ed. Silviculture Systems of Indonesia's Dipterocarps Forest Management: $A$ lesson learned. Technical Report. ITTO Project PD 41/00 Rev.3 (F,M). Faculty of Forestry GMU and ITTO. Pp. 21-24

Strehlke B. 1993. Forest management in Indonesia: employment, working conditions and occupational safety. Unasylva, Vol. 44

Subarudi and Astana S. 2001. Analisis Nilai Tegakan Hutan Alam. Jurnal Sosial Ekonomi, 2(1): 53-69

Sunderlin WD. and Resosudarmo IAP. 1996. Rates and Causes of Deforestation in Indonesia: Toward a Resolution of Ambiguities. Occasional Paper No. 9, Center For International Forestry Research, Bogor, Indonesia

Tacconi L. 2011. Developing environmental governance research: the example of forest cover change studies. Environmental Conservation 38 (2): 234-246

[TBI] The Borneo Initiative. 2012. 2012 Annual Report.

[TNC] The Nature Conservancy. 2012. The Global Forest Alliance: Building Market Linkages to Protect Indonesia's Forests. Program Information

Thompson H and Duggies J. 1996. Political economy of the forestry industry in Indonesia. Journal of Contemporary Asia, 26 (3): 352-365.
Thorburn CC. 2004. The plot thickens: Land administration and policy in post-New Order Indonesia. Asia Pacific Viewpoint, 45 (1): 33-49

van Assen BW. 2005. Diamond Raya Timber Concession: Diamonds are Forever. In: Durst, P.B., Brown, C., Tacio, H.D. and Ishikawa, M. eds. In search of excellence: exemplary forest management in Asia and the Pacific. RAP Publication 2005/02. FAO Regional Office for Asia and the Pacific (FAO RAP) and Regional Community Forestry Training Center for Asia and the Pacific (RECOFTC), Bangkok, 303-314.

Wahyudi 2011. Evaluating the Ideal Silvicultural System for Natural Production Forest Management, Paper Presented at the First International Conference of Indonesian Forestry Researchers (INAFOR), 5 - 7 December 2011, Bogor.

Whitmore TC. 1984. Tropical Rain Forests of the Far East. Second edition. Clarendon Press, Oxford

Widiyatno Soekotjo, Naiem M, Hardiwinoto S and Purnomo S. 2011. Pertumbuhan Meranti (Shorea spp.) pada Sistem Tebang Pilih Tanam Jalur dengan Teknik Silvikultur Intensive. Jurnal Penelitian Hutan dan Konservasi Alam, 8 (4): 373-383.

Williams J. 2001. Financial and Other Incentives for Plantation Establishment. In: Proceeding of the International Conference on Timber Plantation Development. Food and Agriculture Organization of the United Nations, Rome

World Bank. 1990. Indonesia: Sustainable Development of Forests, Land, and Water. The World Bank, Washington, DC.

Wright G. 2011. Indigenous People and Customary Land Ownership Under Domestic REDD+ Frameworks: A Case Study of Indonesia. Environment and Development Journal, 7/2 Law: 117

Yasman I. 1998. Improving Silvicultural Techniques for Sustainable Forest Management in Indonesia. Research in tropical rain forests: Its challenges for the future. The Tropenbos Foundation, Wageningen, the Netherlands.

Yasmi Y, Anshari GZ, Alqadrie S, Budiarto T, Ngusmanto, Abidin E, Komarudin H, McGrath S, Zulkifli and Afifudin. 2005. The Complexities of Managing Forest Resources in Post-decentralization Indonesia: A Case Study from Sintang District, West Kalimantan. Case Studies on Decentralization and Forests in Indonesia No. 10. Center for International Forestry Research, Bogor, Indonesia. 


\section{Appendix 1. FSC-accredited certification bodies operating in Indonesia}

\begin{tabular}{|c|c|c|c|c|}
\hline $\begin{array}{l}\text { FSC-accredited } \\
\text { certification body }\end{array}$ & Type of Certification & Headquarter & Indonesia & Office (and Contact) \\
\hline SGS & $\begin{array}{l}\text { Forest Management, } \\
\text { Chain of Custody }\end{array}$ & $\begin{array}{l}\text { Geneva } \\
\text { (Switzerland) }\end{array}$ & Jakarta & $\begin{array}{l}\text { T: +62 21-7878111, F:+62 21- } \\
7878222\end{array}$ \\
\hline $\begin{array}{l}\text { DNV Business } \\
\text { Assurance (DNV) }\end{array}$ & Chain of Custody & Oslo (Norway) & Jakarta & T: +62 21-29069377 \\
\hline $\begin{array}{l}\text { Scientific Certification } \\
\text { System (SCS) }\end{array}$ & $\begin{array}{l}\text { Forest Management, } \\
\text { Chain of Custody }\end{array}$ & US & Jakarta & $\begin{array}{l}\text { T: +62 21-52897466, Email:Tfrank@ } \\
\text { scsglobalservices.com }\end{array}$ \\
\hline $\begin{array}{l}\text { Control Union } \\
\text { Certification B.V. (CU) }\end{array}$ & $\begin{array}{l}\text { Forest Management, } \\
\text { Chain of Custody }\end{array}$ & $\begin{array}{l}\text { Zwolle (The } \\
\text { Netherlands) }\end{array}$ & Jakarta & $\begin{array}{l}\text { T:+62 21-78842016, F: +62 21- } \\
78842017\end{array}$ \\
\hline $\begin{array}{l}\text { GFA Certification } \\
\text { GmbH (GFA) }\end{array}$ & $\begin{array}{l}\text { Forest Management, } \\
\text { Chain of Custody }\end{array}$ & $\begin{array}{l}\text { Hamburg } \\
\text { (Germany) }\end{array}$ & Jakarta & $\begin{array}{l}\text { T: +62 21-7394041, Email: coof@ } \\
\text { swisscontact.or.id }\end{array}$ \\
\hline BM Trada & Chain of Custody & Wycombe (UK) & Jakarta & $\begin{array}{l}\mathrm{T}:+62 \text { 2-8740202, F: +62 21- } \\
87740745\end{array}$ \\
\hline $\begin{array}{l}\text { Bureau Veritas } \\
\text { Certification Holding } \\
\text { SAS (BVC) }\end{array}$ & $\begin{array}{l}\text { Forest Management, } \\
\text { Chain of Custody }\end{array}$ & $\begin{array}{l}\text { Neuilly-sur- } \\
\text { Seine (France) }\end{array}$ & Jakarta & $\begin{array}{l}\text { T: + } 62 \text { 21-5210393, F:+ } 62 \text { 21- } \\
5210806\end{array}$ \\
\hline $\begin{array}{l}\text { QMI-SAI Global } \\
\text { Assurance Services } \\
\text { (QMI) }\end{array}$ & $\begin{array}{l}\text { Forest Management, } \\
\text { Chain of Custody }\end{array}$ & $\begin{array}{l}\text { Toronto } \\
\text { (Canada) }\end{array}$ & Jakarta & $\begin{array}{l}\text { T:+62 21-7206460, F:+62 21- } \\
\text { 7206207, Email: Marketing. } \\
\text { indonesia@saiglobal.com }\end{array}$ \\
\hline TUV Nord & Chain of Custody & $\begin{array}{l}\text { Essen } \\
\text { (Germany) }\end{array}$ & Jakarta & T:+62 21-78837338 \\
\hline $\begin{array}{l}\text { Rainforest Alliance \& } \\
\text { Smartwood (RA-SW) }\end{array}$ & $\begin{array}{l}\text { Forest Management, } \\
\text { Chain of Custody }\end{array}$ & New York (US) & Denpasar & $\begin{array}{l}\text { T: +62 361-256689, F:+62 361- } \\
\text { 256634, Email:asia_pacific@ra.org }\end{array}$ \\
\hline
\end{tabular}




\section{Typology of natural Forest Management Units (FMUs) in Kalimantan}

Ruslandi ${ }^{1}$ and Claudia Romero

\subsection{Introduction}

Market-based, voluntary forest management certification, which has been operating for almost two decades, is claimed to improve forest management practices (e.g., Moore et al. 2012, Nebel et al. 2005, Newsom et al. 2005, PeñaClaros et al. 2009, Rametsteiner and Simula 2003, Ruslandi et al. 2014). Unfortunately, few empirical evaluations of this conservation strategy have been carried out to date, particularly for natural tropical forests (Miteva et al. 2012, Moore et al. 2012, Romero et al. 2013). The only two studies that evaluated the impacts of certification in tropical forests were based on comparisons of certified and un-certified forest management units (FMUs) selected with a subjective matching process (Barbosa de Lima et al. 2009 and Cerutti et al. 2014).

A properly designed field-based evaluation of forest certification impacts is time-consuming, costly, and field-work and data intensive but also methodologically challenging (Moore et al. 2012, Romero et al. 2013). For one thing, FMUs are not randomly allocated into certified (treatment) or uncertified (control) groups. Added to this selection bias, is the fact that there are confounding observable and non-observed factors that influence decisions FMUs make for engaging in certification and that also influence the outcomes of forest management itself. Given these conditions, a Before-After Control-Impact (BACI) could help determine the added value of certification. Matching on confounding variables between treatment (certified) and control (uncertified) units should help to correctly attribute observed differences to adoption of certification.

1 Ruslandi, Department of Biology, University of Florida, Gainesville, FL, USA. r.ruslandi@ufl.edu
But even before getting to this stage, it seems important to categorize FMUs on the basis of shared characteristics and to use these groups in the selection of counterfactuals.

Other researchers have endeavored to create typologies of FMUs. In a study in the Congo Basin, a number of forest concession attributes (e.g., location, age, size, annual harvest, legal status, capital origin, market orientation) were used to characterize the forest sector (Ruiz Perez et al. 2005). In Brazil, additional factors included the age of the forest frontier where the FMUs are located (Lentini et al. 2003). Some of these characteristics useful for classification have also been linked with better forest management practices. For example, in the Congo Basin study, researchers reported that FMUs with European capital employed better forest management practices than those with Asian-origin capital (Ruiz Perez et al. 2005). In Brazil, age of forest frontiers was associated with technological developments of FMUs (Merry et al. 2006).

In Indonesia, the government divided forested territories into three regions for the purpose of setting concession permit fees (GoI 1998), presumably based on different timber stocking. These areas are: (1) Sumatra and Sulawesi; (2) Kalimantan and Maluku; and (3) Papua and Nusa Tenggara. The highest fees were applied to the Kalimantan and Maluku region, followed by Sumatra and Sulawesi, and then the Papua and Nusa Tenggara regions. Rates are also lower in logged-over than in primary forests. Another grouping of forests was developed in 2007 by the Ministry of Forestry (MoF 2007) to define the number of samples required for forest inventories at the concession level. This system was based on the coefficient of variation $(\mathrm{CV})$ of timber volume; more samples are required in Kalimantan and Maluku than in the other two regions. 
For the purposes of evaluation of the impacts of Forest Stewardship Council (FSC) certification of natural forest management in Indonesia, a more systematic approach to FMU typology building was used and reported here. FMUs operating in natural tropical forests in Kalimantan were grouped on the basis of variables thought to be associated with engagement in certification and with the outcomes of forest management interventions. It is expected the study will provide insights to inform and guide the construction of a counterfactual to be used in a field-based, forest certification impact evaluation.

\subsection{Methods}

Various variables (see survey matrix in Appendix I) were used to identify similarities and differences among FMUs in Kalimantan in two steps through multivariate analysis (Everitt and Hothorn 2011). The focus on Kalimantan is justified because all FSC-certified concessions in Indonesia are located here except PT. Diamond Raya, which is in a Sumatran swamp forest. Restricting the analysis to Kalimantan also seems justified given the substantial biophysical, economic and social differences among the major islands in Indonesia. The study period corresponds to FMUs operating until 2012.

\subsubsection{Data collection process and sources}

Various sources of data were used to construct the FMU typology including:

- Statistical reports and databases at the MoF (e.g., MoF 2012). Initial data collected referred to the list of FMUs with valid concession permits in 2012 and their basic information (e.g., location, area, type and duration of permit). Because FMUs might be more prone to pursue certification if they log continuously, data collection was restricted to only those FMUs with active logging operations.

- Approved long-term management plans of FMUs at the MoF database [available online (MoF 2014a; http://www.dephut.go.id/index. $\mathrm{php} /$ common/uud_filterby ]. These documents were consulted to obtain data on annual harvesting targets (e.g., area, volume and logging intensity). Complementary data on the approved annual work plan were obtained from MoF reports, which are also available online (MoF 2014b; http://www.dephut.go.id/index. $\mathrm{php} /$ news/otresults/1308).
- Demographic information (e.g., population density and growth) was obtained from the National Population Census 2010, which is available online (BPS 2014; http://sp2010.bps. go.id/index.php/publikasi/index). Data were extracted at the sub-district and district levels where the specific FMU is located. Population density was calculated as the population density average of sub-districts or districts where the FMU is located. Population growth was averaged over a 10 year period $(2000-2010$ : a period between national population census).

- Data on the FMU area that was previously logged and its classification as either "production forest" or "limited production forest" were available from the MoF website (MoF 2014c; http://appgis.dephut.go.id/ appgis/iuphhk.aspx).

- Deforestation rate data (2000-2009) at the Province level were obtained from a report by the NGO Forest Watch Indonesia (FWI 2011; http://fwi.or.id/wp-content/uploads/2013/02/ PHKI_2000-2009_FWI_low-res.pdf ).

- Data on legal frameworks and political cohesion of forestry industries were obtained from scientific literature and reports (e.g., Barr et al. 2006, Brown 1999, Kartodihardjo 1999).

- Information on existing FMUs groupings was obtained from the regulations issued by the Government of Indonesia and the MoF (GoI 1998; MoF 2007).

- Management status information was obtained from the MoF databases (SLVK-legality verification and PHPL-Mandatory certification for SFM)(MoF 2014d; http://www.dephut. go.id/index.php/common/vlk and MoF 2014e; http://www.dephut.go.id/index.php/common/ phpl).

- Certification coaches and NGOs (e.g., The Borneo Initiative, Tropical Forest Foundation, The Forest Trust, The Nature Conservancy, and WWF) provided data on improved forest management programs in which FMU staff participated. Capacity-building activities included training on Reduced-ImpactLogging (RIL), social surveys and community development, biodiversity surveys and conservation planning, and on other aspects of forest management. In general, training was provided separately for each participating FMU.

- Information about parent company (group) membership, origin and capital source for FMUs, market orientation, extent of forest industry integration, logging sub-contracted and other economic variables for each FMU 
and their parent companies was obtained from the Indonesian FMU association (APHI 2014; http://www.rimbawan.com/anggota/daftaranggota) and complemented with informal conversations with certification coaches, FMUs, NGOs, and CBs.

- Finally, informal conversations were held with representatives of FMUs, certification coaches (local or international NGOs with offices in Jakarta), the Indonesian FMU association, and CBs with offices in Jakarta (See Appendix II for full list of people contacted, their affiliations, and contact information). The conversations focused on improved forest management programs in the FMUs, existing and potential social conflicts in the FMUs, market orientation, and other related topics.

\subsubsection{Data analysis}

First, quantitative and qualitative variables were used to perform a multivariate factor analysis (MFA) to define the structure of the interrelationships (correlations) among the set of variables in the dataset based on groups of variables. Only the first two dimensions were used for ease of interpretation and to increase stability of the dimensions (Husson et al., 2013). Variables for which there was not sufficient variation across the samples or that were tightly correlated and thus had a reduced separation function and could also increase bias were not included in the MFA (e.g., name of parent company, permit, management). That information was used to interpret the final results.

An MFA was run with all selected variables and those that were weakly loaded $(<0.5)$ in the first two dimensions were excluded from further runs. The variables were subsequently separated into active variables, those that would be used to construct the dimensions and inform their interpretation, and inactive or supplementary variables (e.g., FSC: $\mathrm{Y} / \mathrm{N}$ ) that would help in the interpretation of the results. In all iterations of the MFA, the supplementary inactive group contained only information pertaining to FSC certification. The stages used were: considering certification (i.e., the FMU has received support or capacity-building activities from certification coach institutions such as TBI, TFF, TFT, TNC, WWF, APHI); en route to certification (i.e., the FMU has undergone pre- and/or full certification assessments); FSC certified; and never certified (i.e., FMUs that have never been engaged in certification; Ruslandi, Chapter 4 in this volume).
The remaining qualitative and quantitative variables were grouped based on how they related to specific FMU characteristics. For instance, variables related to market characteristics of the FMU were grouped together (e.g., subcontracted or not, market outlets, origin of FMU, age).

Other variables that were more associated with the forest itself were assigned to another group (e.g., $\%$ logged). Iterations of different models were run and the one that explained the most inertia was selected. This model includes the following variables and groups:

\section{- Active Groups:}

AREADeM: FMU area (in ha) and population within FMU (\# inhabitants $\mathrm{km}^{-2}$ )

Forest: \% FMU under Limited Production ${ }^{2}$

Market: Regime (public and private); Origin (Indonesian or other countries); Age (Old: established before 1998 and NEW after 1998); Integrated (vertically integrated $\mathrm{Y} / \mathrm{N}$ ); Outlet (market destination of harvested timber as Domestic; Export; Both); Logging subcontracted $(\mathrm{Y} / \mathrm{N})$

- Inactive Variable: FSC (never engaged in certification, considering certification, en route to certification, and certified).

The second step of the analysis was to perform a hierarchical clustering of the principal components (HCPC) of the MFA results. The goal was to use this methodology to quantify the structural characteristics of the MFA scores for each individual FMU in the two dimensions of the MFA. The information is presented as a hierarchical clustering tree (Everitt and Hothorn 2011) and depicts groups of FMUs most similar to each other that are located on the same branch of the tree. FMUs were sorted along the two dimensions according to the coordinates on each principal component. The clustering method used was Ward and distances were Euclidean. The $k$-means procedure was used to achieve better consolidation of the clusters so that these are more homogeneous. All analyses were run in $\mathrm{R}$ (R Development Core Team 2008) using the FactoMineR package (Husson et al. 2013).

2 Limited Production Forests have average slopes $>25 \%$ and can be logged only at a low intensity (i.e., a higher minimum diameter cutting limit than in Production Forests). 


\subsection{Results}

FMUs presented a different level of heterogeneity in all variables (Appendix III). A detailed description of those variables used in the analyses will be given in the next sub-section. A general description of remaining variables is included in Appendix V.

\subsubsection{Main characteristics of FMUs}

FMUs ranged from $10,100-355,800$ ha (mean $=64,154 \mathrm{ha})$. Population densities within the FMU were also quite variable: from 1 to 60 inhabitants $\mathrm{km}^{-2}$, although the great majority of FMUs were not so densely populated (Mean $=8$ inhabitants $\mathrm{km}^{-2}$ ). The mean proportion of FMU land classified as for Limited Production was $63.4 \%$ (range $=0-100)$.

Categorical variables showed slightly less variation, except for Age. FMUs seem to be evenly distributed between the Old and Young groups. In contrast, most FMUs were privately-owned (94.5\%; Table 3.1).

\subsubsection{MFA}

The first and second dimensions explained 30.6 and $20.8 \%$ of the inertia, respectively, for a total of $51.4 \%$. The groups AreaDem and Market were more correlated with the Dimension 1 and each contributed more than $47 \%$ to construction of the first axis (Figure 3.1). Yet, the quality of representation in that axis was lower for Market (0.31) than for AreaDem (0.49) so that this first dimension represents a gradient of variables in the group AreaDem and to a lesser extent of variables in the Market group. The inactive variable (FSC) is moderately correlated with Dimension 1, though its quality of representation is low. Its contribution to either axis is not relevant since as an inactive variable it did not participate in the construction of the dimensions (Table 3.2).

Within the AreaDem group and Dimension 1, the quality of representation for Population within $F M U$ is low $(<0.05)$. Thus, the most important variable in that group is Area $(0.70 \%)$.

Variables in the Forest group were highly correlated with Dimension 2. In this case, this group only had one variable (i.e., \% Limited Production).
Table 3.1. Description of categorical variables used to construct a typology of active FMUs operating in natural forests in Kalimantan, Indonesia ( $\mathrm{N}=171)$.

\begin{tabular}{lrr}
\hline Variables & \multicolumn{1}{c}{$\#$} & \multicolumn{1}{c}{$\%$} \\
\hline Age: Old (Before 1998) & 87 & 50.9 \\
Age: New (After 1998) & 84 & 49.1 \\
Vertically Integrated (YES) & 32 & 18.7 \\
Vertically Integrated (NO) & 139 & 81.3 \\
Capital Origin (Foreign) & 11 & 6.4 \\
Capital Origin (Domestic) & 160 & 93.6 \\
Market Outlet (Domestic) & 112 & 65.5 \\
Market Outlet (Export) & 43 & 25.1 \\
Market Outlet (Both) & 16 & 9.4 \\
Logging Subcontracted (NO) & 61 & 35.7 \\
Logging Subcontracted (YES) & 110 & 64.3 \\
FSC en route & 8 & 4.7 \\
FSC interested & 44 & 25.7 \\
FSC certified & 12 & 7.0 \\
NEVER FSC engaged & 107 & 62.6 \\
\hline
\end{tabular}

Groups representation

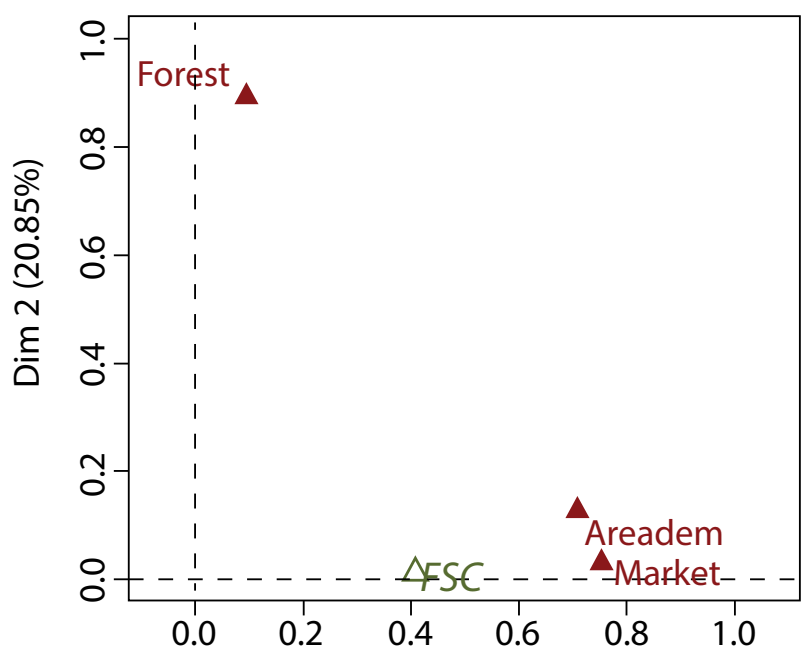

$\operatorname{Dim} 1$ (30.57\%)

Figure 3.1. Results of a MFA on groups of variables related to Market, Area and population, and Forest characteristics of FMUs operating in natural forests in Kalimantan, Indonesia $(\mathrm{N}=171)$. The variable FSC was added to aid in the interpretation of the MFA but was not used in its construction. 
Table 3.2. Correlations between groups of variables and each of the two dimensions of the MFA of natural forest FMUs in Kalimantan ( $N=171)$. Contrib. represents the proportion that each variable contributes to each axis, and $\cos 2$ assesses the quality of information contributed.

\begin{tabular}{lcclccc}
\hline Groups & Dimension 1 & Contrib. & Cos2 & Dimension 2 & Contrib. & Cos2 \\
\hline Areadem & 0.70 & 47.21 & 0.49 & 0.07 & 7.71 & 0 \\
Forest & 0.06 & 3.84 & 0 & 0.91 & 89.76 & 0.83 \\
Market & 0.72 & 48.93 & 0.31 & 0.02 & 2.51 & 0 \\
FSC (Inactive) & 0.41 & - & 0.05 & 0 & - & 0 \\
\hline
\end{tabular}

Table 3.3. Contribution, quality of representation, and test statistics for continuous and categorical variables used in a multiple factor analysis (MFA) grouped in AreaDem, Forest, and Market groups for FMUs operating in natural forests in Kalimantan $(\mathrm{N}=171)$.

\begin{tabular}{llcccccc}
\hline Groups & Variables & \multicolumn{3}{c}{ Dimension 1 } & \multicolumn{3}{c}{ Dimension 2 } \\
\cline { 3 - 7 } & & Contribution & Cos $^{2}$ & $\mid$ V-test $\mid$ & Contribution & Cos $^{2}$ & $\mid$ V-test $\mid$ \\
\hline AreaDem & Area FMU & 47.21 & 0.70 & & 7.71 & 0.08 \\
& Pop. Within FMU & 0 & 0.03 & & 0 & 0.07 \\
\hline Forest & \% Limited Production & 3.85 & 0.05 & & 89.8 & 0.91 \\
\hline Market & New (after 1998) & 5.37 & 0.73 & 8.07 & & \\
& Old (before 1998) & 5.19 & 0.73 & 8.07 & & \\
& Integrated YES & 11.50 & 0.83 & 9.34 & & & \\
& Integrated NO & 2.64 & 0.83 & 9.34 & & & \\
& Domestic market & 3.98 & 0.74 & 8.43 & & 0.06 & 2.14 \\
& Origin Indonesia & & & & 0.07 & 0.06 & 2.14 \\
\hline
\end{tabular}

Both the contribution to the construction of the group as well as the quality of representation for this group were high $(>89 \%)$. Thus, that dimension represents an axis of variation in Forest characteristics, that is, in the extent to which the FMU has areas designated as Limited Production Forest. Both contribution to Dimension 2 (0.90) and quality of representation of this variable were high (0.91; Table 3.3). The supplementary group, as expected, did not contribute to the construction of either dimension.

Regarding Market variables, the ones positively correlated with Dimension 1 were FMU Age Old (before 1998) and Vertically Integrated-YES (v-test $>|2|$, indicating that the coordinate is significantly different from zero). Negatively correlated variables with that Dimension were FMU Age New, Vertically Integrated -NO, and Outlet for Domestic market. As for Dimension 2, only Origin of FMU/ Capital was significantly correlated with the axis: Foreign positively and Indonesian negatively.

\subsubsection{Hierarchical Clustering on Principal Components (HCPC)}

This analysis was performed on the resulting scores for individuals from the MFA for the first two dimensions. Overall, FMUs were sorted out into four clusters (Figure 3.2).

On categorical data, chi-square tests indicate that the variables Age, Integrated, Outlet, Subcontract, and FSC status are linked to the clusters. For continuous data, one-way ANOVA results highlight that the variables linked to the clusters are \% Limited Production, Population Density within FMU, and Area (Figure 3.3).

Cluster 1 (black in Figure 3.3; 58 FMUs; FSC certified: 0; Never Engaged in Certification: 48; Interested: 10; Appendix IV)

This cluster is significant and negatively correlated with Dimension $1 \mid \mathrm{v}$-test $=6.4 \mid$ and both significant and positively correlated with Dimension $2 \mid \mathrm{v}$-test $=-6.0 \mid$. 


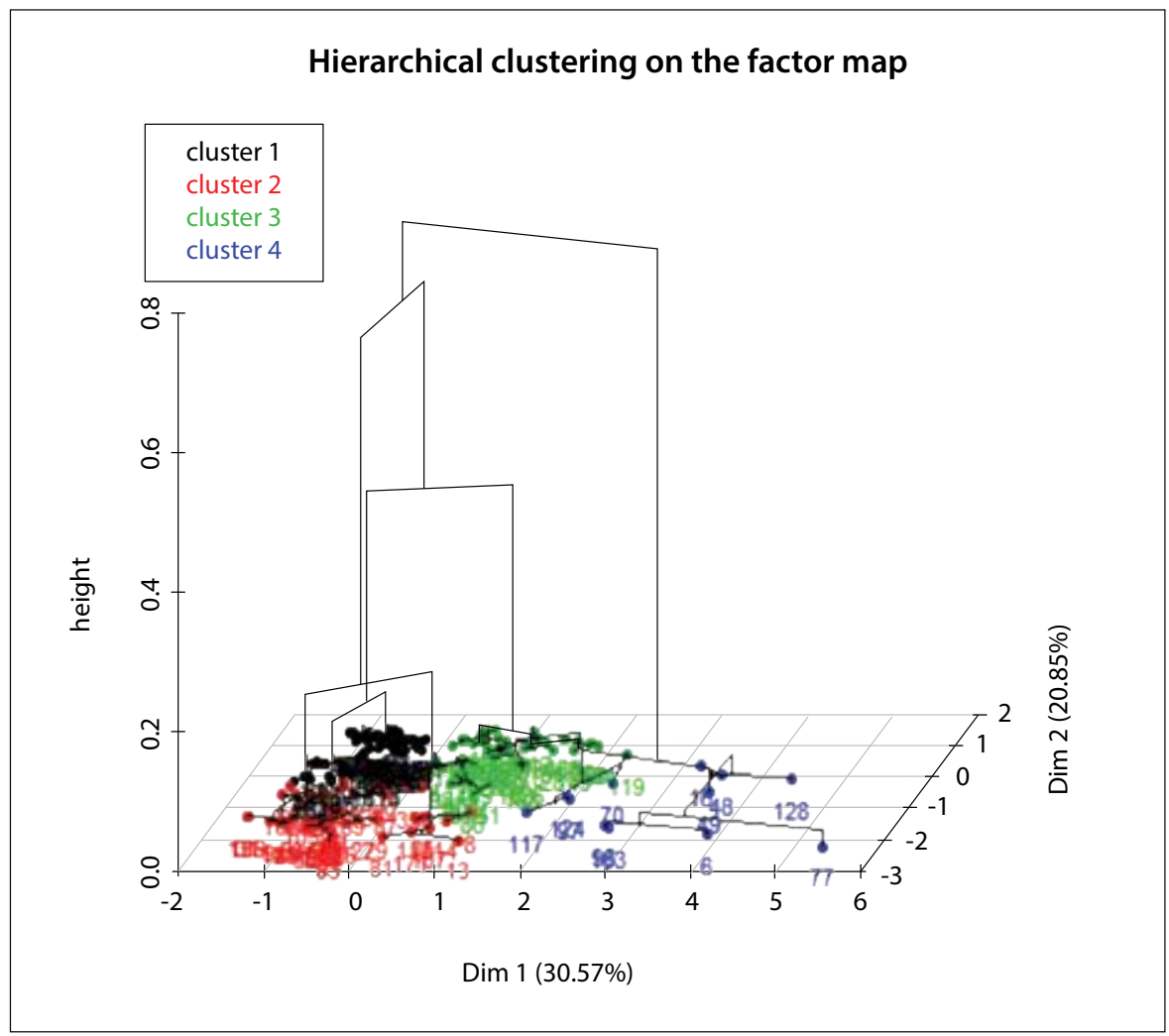

Figure 3.2. Hierarchical tree showing the relationships among FMUs operating in natural forests in Kalimantan based on the scores of a multiple factor analysis on the first two axes ( $\mathrm{N}=171 ; \sim 51 \%$ of variance explained). Colors represent different cluster memberships. Descriptions of each cluster are provided in the text. Numbers correspond to FMU identities (Appendix 4).

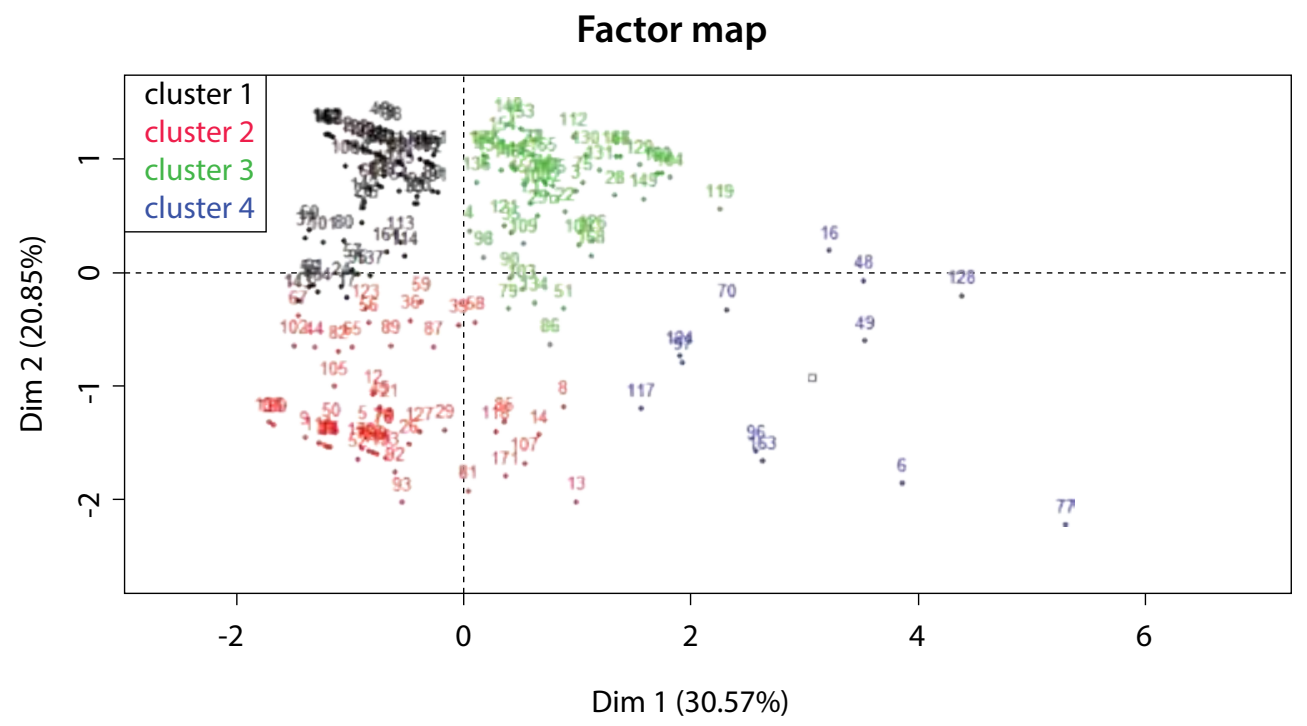

Figure 3.3. Results of a hierarchical clustering on the resulting scores of a MFA for FMUs operating in natural forests in Kalimantan. FMUs differ in area, human population densities within the FMUs, and \% of the FMU classified as Limited Production Forest in Dimension 1. Dimension 2 separates FMUs on the basis of variables related to Market characteristics (see text for explanation), as well as age. Numbers correspond to FMU identities (Appendix 4). 
FMUs in this cluster are typically small (Mean $=39,456 \mathrm{ha}$ ) and have a large proportion of their area classified as Limited Production Forest (Mean $=85.1 \%)$ when compared to the overall mean. None of the FMUs in this cluster are vertically integrated, taking into consideration that $41.8 \%$ of FMUs without vertically-integrated markets are in this cluster of the 81.2 present in the sample. The great majority of FMUs in the cluster are New, sell timber domestically, subcontract out their logging operations, and are owned by Indonesian-based parent companies (84.5\%). All of these traits, except for FMU ownership, have larger proportions than observed in the overall sample (Table 3.1). About $45-58 \%$ of the FMUs with these traits are in this cluster. In the case of FMU ownership, only $31.9 \%$ of FMUs with these traits are in the cluster.

In terms of FSC certification status, a large proportion $(82.8 \%)$ of the FMUs in this cluster never engaged in certification. Most are nonintegrated FMU with a high \% of limited production forests (mean $=85 \%$ ) and relatively small area (mean $=39$ thousand ha). Seven of these FMUs are foreign-based (PT. Fortuna Cipta Sejahtera, PT. Gaung Satya Graha Agrindo, PT. Karya Delta Permai, PT. Menorah Loggingindo, PT. Sarana Piranti Utama, and PT. Trisetia Citagraha), all from Malaysia expect for the last one that is from Korea. Only 15\% of these FMUs are old.

Those that have taken any steps towards certification $(\mathrm{N}=10)$ went only as far as being interested in certification. All of these FMUs are private, non-integrated FMUs, with areas that range from $25-71$ thousand ha. All except for PT. Tingang Karya Mandiri target exclusively domestic markets. All of the companies are private except for two para-statal ones $(P T$. Inhutani I -Unit Pangean and PT.Inhutani I-Unit Segah Hulu). They practice mostly IFM and just 4 do SVLK.

\section{PT. Aditya Kirana Mandiri, a relatively small} $(\sim 40$ thousand ha) FMU that targets domestic market is the closest to the center of gravity of this cluster. This FMU just became involved in certification through the support of TBI in 2013. CV. Bakti Dwipa Kariza a much smaller FMU $(\sim 11$ thousand ha) also targeting the domestic market has never acted towards certification and is the most typical FMU to Cluster 1. It is a nonvertically integrated FMU that also targets the domestic market.
Cluster 2 (red in Figure 3.3; N=50 FMUs; FSC certified: 1; Interested: 16; Appendix IV)

This cluster is significantly and negatively correlated with Dimensions 1 and 2 (v-test $=-4.4$ and -10.2 , respectively). Mean area is 55 thousand ha and mean proportion of limited production is the lowest of all clusters (13\%). It is characterized by FMUs that for the most part are not vertically integrated and subcontract their operations (>80\% FMUs in the cluster share both those traits). The cluster also contains over $65 \%$ of the sample of FMUs with those characteristics, and about 35\% of FMUS that are not vertically integrated and subcontract their operations. Most FMUs are new (58\%), and PT. Trisetia Intiga is the only foreign FMU (Korea).

A few FMUs in this cluster export timber (14\%) compared to $25.1 \%$ of the overall sample. Likewise, the \% Limited Production Forest is much smaller $(13.6 \%)$ than the overall mean or than cluster $1(85.1 \%)$. FMUs within this cluster are in sub-districts with relatively high population densities, almost double those of cluster 1 (6.6 inhabitants ha ${ }^{-1}$ ) and much higher than the overall mean.

Most (33) of the 50 FMUs in this cluster have never been engaged with certification. Their areas range between 12-124 thousand ha with low limited production forests $(-9 \%)$. The great part of these FMUs are new (63\%), and only one firm is integrated (PT. Rimba Karya Rayatama), targeting exclusively Asian markets.

Of the 17 FMUs that have taken steps towards certification in this cluster, one has been certified (PT. Dwima Jaya Utama), a relatively large and old FMU with $<20 \%$ limited production that gained certification just in 2013 with SCS, in spite of having had a first pre-audit in 2003 with RA. This FMU is located at an intermediate distance from the edge of Cluster 3. The remaining 16 FMUs reached only the interested in certification status. Of these, 12 target exclusively domestic markets and 10 of these are old with areas that range from $35-131$ thousand ha with a mean of $21 \%$ limited production forests.

PT. Graha Sentosa Permai, a relatively small (44 thousand ha) and new FMU that exports to a range of countries is located closest to the center of gravity of this cluster. It has manifested interest in certification since 2007 when its staff received 
RIL training and further support from TBI in 2012. PT. Inhutani II (Eks PT. Genwood)-Sei Tubu, a para-statal FMU, a large ( -99 thousand ha) and new (est. 2011) non-integrated FMU that targets domestic markets is the most characteristic of this cluster. It became recently interested in certification through the support of TBI in 2013 and is the most different from all the other FMUs in all clusters.

Cluster 3 (green in Figure 3.3; N=51 FMUs; FSC Certified: 11; Interested: 16; En route: 6; Never: 18; Appendix VII)

This cluster is significantly correlated with Dimensions 1 and 2 (v-test $=5.6$ and 5.4, respectively). The area of the FMUs in the cluster range between 10 and 138 thousand (mean: 65 thousand ha) with a high proportion under limited production (89\%). This cluster only has one para-statal FMU (PT. Inhutani I-Unit Sambarata). Most of these FMUs were created before 1998 (86.3\%), which is also higher than the overall mean; $50.9 \%$ of the old FMUs are in this cluster. Most FMUs in this cluster do not subcontract their operations $(76.5 \%)$, which is higher than the overall proportion (64\%). To varying degrees, FMUs in this cluster both export timber (e.g., Japan, European Union, and the US, although there some sell to Asia; 47.1\%) and sell on domestic markets (19.7\%). They are mostly not vertically integrated (62.7\%). Heterogeneity in these variables can also be seen at the level of FMUs of the sample that are in this cluster, and that have these traits (23\%-63\%).

Seven FMUs in this cluster are FSC certified, and they are all old national firms targeting exclusively export markets. The area of the 6 FMUs that are en route to certification ranges from 41 to 138 thousand ha and a high proportion of limited production (86\%). Two of these are old FMUs that only sell timber domestically (PT. Gunung Gajah Abadi and PT. Inhutani I-Unit Labanan).

The area of the 16 FMUs interested in certification is from 10 to 100 thousand ha, mostly in high limited production (90\%). A quarter of these FMUs are new and overall, only 5 target domestic markets.

The great part of the never certified FMUs are old, and interestingly $60 \%$ of these export timber. Their areas range from $27-143$ thousand ha with a high proportion of limited production forests.
PT. Sumber Mas Timber, a medium-sized old FMU ( -53 thousand ha) that exports to Asia has never shown interest in certification. It is located closest to the center of gravity of this cluster. PT. Sumalindo Lestari Jaya IV (eks PT. Madyakara Pacific) an FMU of similar size ( -64 thousand ha) that also targets a diversity of export markets is the most specific FMU to this cluster. It started engagement with certification in 2012 with the support of TBI.

Cluster 4 (blue in Figure 3.3; N=12; FSC certified: 7; Interested: 2; En route: 2. Appendix IV)

This cluster shows a significant positive correlation with Dimension 1 (v-test $=9.0)$ and a significant negative correlation with Dimension 2 $(v$-test $=-3.2)$. This is the cluster with the smallest number of FMUs. It contains the largest FMUs $(\mathrm{MEAN}=201,428 \mathrm{ha})$, over three times the overall mean and also medium proportion of limited production forest (56\%). All FMUs in this cluster are Old: $15 \%$ of all Old FMUs in the overall sample are in this cluster of the $50.8 \%$ Old FMUs in the sample. The majority of FMUs in this cluster do not subcontract, are vertically integrated, and exports their products (all > 83.3\%); all values are above their respective overall means. However, there is heterogeneity in the extent to which FMUs with these traits are in this cluster (16-34\%). All FMUs are Indonesian-based, except for PT. Balikpapan Forest Ind. from Korea.

Almost 59\% of FMUs in the cluster are FSC certified in contrast to only $7 \%$ in the overall sample. PT. Ratah Timber and PT. Rodamas Timber Kalimantan got training from TFT in 2001. The first one got a pre-assessment with SGS in 2009, a full assessment in 2011 and became certified in 2013. The second one got pre and full assessments in consecutive years (2011 and 2011) with CU and became certified in 2012. Suka jata Makmur got a RIL-training in 2003, and pre and full-assessments also in consecutive years (2009 and 2010) with CU and obtained certification in 2011. Sari Bumi Kusuma participated in a USAID funded training on IFM and RIL in 2001. It had a full-assessment in 2003 with RA, became certified in 2006 and recertified in 2011. PT. Intraca Wood Manufacturing and Erna Djuliwati joined the APHI SFM program in 1996. The first FMU had pre- and full assessments in consecutive years with RA (2000 and 2001), and became certified and suspended in 2004. It became again certified not only through FSC but also LEI with 
RA in 2006 and again lost certification in 2011. In 2012 it became certified again with the same $\mathrm{CB}$. The second one had pre- and full assessments in 2001 with SGS and became FSC and LEI certified with RA and TUV respectively in 2005. It got recertified in 2010.

Except for one FMU that has never engaged in certification (see below), the remaining FMUs are either interested or en route to certification. Two FMUs are in this last category with similar area (255-355 thousand ha), PT. Austral Byna and PT. Essam Timber. Austral Byna participated in APHI's SFM program in 1996. It was not until 2000 that it got a pre-assessment followed by a full one in 2003 both with RA, but has never taken further steps. PT. Essam Timber is a very large old FMU that only exports to Asia. It is one of the few publicly traded FMUs in the country. This FMU was originally controlled by the Kalimanis group (Bob Hasan company) and projected to get FSC certified. But once the commercial group collapsed after Soeharto stepped down it has not been permanently active in logging.

The FMUs interested in certification are PT. Balikpapan Forest Ind. and PT. Sumalindo Lestari Jaya II. The first one applies SVLK. The second one PHPL and joined the APHI SMF program in 1996. It got a full assessment with RA in 2003. It gained both LEI and FSC certification in 2006 with RA but lost them in 2011.

The only FMU in the never certified category is PT. ITCI Kayan Hutani (PT. IKANI), a large FMU ( -213 thousand ha) that targets domestic markets and belongs to militarycontrolled business. Because its operations are subcontracted, the market strategy is mostly defined by the contractor. It is the only FMU in the cluster that sells timber only domestically.

\section{PT. Sarmiento Parakantja is a typical FMU in} this cluster and is located closest to its theoretical center. It is an old large FMU ( -217 thousand ha) that targets export markets and became engaged in certification activities since 2001, when its staff received RIL training. It remained considering certification until 2007 when it became LEI certified. It was not until 2011 that it received its FSC certification through RA. PT. Essam Timber is the most typical FMU on this cluster.

\subsection{Discussion and conclusions}

Virtually all natural forests in Indonesia are owned by the state and managed through a concession system following the Indonesian selective logging program (TPTI). In spite of a single ownership and management system, FMUs are heterogeneous in their biophysical, social, economic, and market traits, which may influence their forest management practices and thus certification decisions. Although variation in some traits was minimized by restricting the analysis to Kalimantan, there is still considerable variation within that region. Because FSC certification is voluntary and reportedly attracts FMUs that employ better forest management practices (i.e., a positive self-selection bias; Barbosa de Lima et al. 2009, Nussbaum and Simula 2004, Thornber et al. 1999, Ruslandi Chapter 5 in this volume), the existing heterogeneity should be considered when attempting to evaluate the impacts of forest certification.

Based on FMU age, vertical integration, market outlet, and whether or not logging is subcontracted (as categorical variables) and proportion of limited production, local human population density, and area (as continuous variables), four groups of FMUs were identified. It is important to note though that some FMUs reach international markets in spite of not being vertically integrated, mostly through their industry partners. Cluster 1 was characterized by FMUs not integrated with processing industries, domestic outlet, logging subcontracted, never certified, high percentage of limited production forest, and low human population density. These FMUs are mostly new with most of the old ones in the cluster not actively logging. The 10 FMUs interested in certification in this cluster are taking opportunities offered by forest-market linking programs, which means that their commitment and the capacity to engage in certification is not strong (Ruslandi, Chapter 5 in this Volume). Cluster 2 was similar to Cluster $\mathbf{1}$ except for lower percentage of limited production forest and population density. In addition, one certified FMU was part of this group. It is different from other clusters because all its member FMUs have a low percentage of limited production forest $(<$ $50 \%$ ). The large Cluster 3 was distinguished by a large proportion of limited production forests, old FMUs, not subcontracted logging operations, 
and mostly export-oriented. In contrast, Cluster 4 was typified by large and old FMUs that are integrated, do not subcontract their logging operations, and mostly export. Almost all FMUs in this small group (7 of 12) have engaged in forest certification.

FMU variables contributing most to the inertia were related to timber production capacity (i.e., FMU size and percentage of limited production forest), social conflict potential (i.e., population density), and operational management and market orientation (i.e., subcontract, vertically integration). Given that the information used about markets (e.g., vertical integration or market outlet), was completed based on records from the legal formal relationship among FMUs and forest industries (i.e., the group of forest companies in the APHI member directory), it is doubtful that all of the commercial interactions of FMUs were captured. It is likely, for example, that some independent FMUs are indirectly but strongly related to particular forest industries. Some FMUs reported as serving mostly domestic markets might actually be connected to export market though purchasing agreements with their forest industry partner or logging contractors, but establishing these linkages proved challenging. Certainly this is one area where more accurate and representative information can be collected during the empirical evaluation.

This study shows different types of FMUs sorted in contrasting clusters based on information at one point in time; whereas certification status and some other traits vary over time. This first approach to understanding the FMU sector in Indonesia can nevertheless help to design the field portion of the impact evaluation. In particular, the typology presented can inform the selection of counterfactuals. In that respect, FMUs could be drawn from Clusters 2, 3, and 4 which all contain certified and never engaged in certification FMUs.

\subsection{References}

[APHI] Asosiasi Pengusaha Hutan Indonesia. 2014. Daftar anggota Asosiasi Pengusaha Hutan Indonesia periode 2011 - 2016. Available at: http://www.rimbawan. com/anggota/daftar-anggota. Accessed 10 June 2014.
Barbosa de Lima A, Novaes Keppe AL, Maule FE, Sparovek G, Corréa Alves M, and Maule RF. 2009. Does certification make a difference? Impact assessment study on FSC/SAN certification in Brazil. Available at: http://www.imaflora.org/arquivos/Does_ certification_make_a_difference.pdf

Barr C, Resosudarmo IAP, Dermawan A, McCarthy J, Moeliono $M$ and Setiono B. eds. 2006. Decentralization of forest administration in Indonesia: Implications for forest sustainability, community livelihoods, and economic development. CIFOR, Bogor, Indonesia. 178p.

[BPS]Badan Pusat Statistik. 2014. Publikasi SP2010. Badan Pusat Statistik Republik Indonesia. Jakarta. http://sp2010.bps.go.id/ index.php/publikasi/index.

Accessed 10 June 2014.

Brown DW. 1999 Addicted to rent: corporate and spatial distribution of forest resources in Indonesia. Implications for forest sustainability and government policy. Jakarta (Indonesia): Indonesia-UK Tropical Forest Management Program, Report No. PFM/EC/99/06.

Cerutti PO, Lescuyer G, Tsanga R, Kassa S.N, Mapangou PR, Mendoula EE, MissambaLola AP, Nasi R, Eckebil PPT and Yembe RY. 2014. Social impacts of the Forest Stewardship Council certification: An assessment in the Congo basin. Occasional Paper 103. CIFOR, Bogor, Indonesia.

Everitt B and Hothorn T. 2011. An Introduction to Applied Multivariate Analysis with R. Heidelberg: Springer. 273 pages. ISBN: 9781-441-99649-7.

[FWI] Forest Watch Indonesia. 2011. Potret Keadaan Hutan Indonesia periode 2000 2009. Edisi Pertama, Bogor. Available at: http://fwi.or.id/wp-content/uploads/2013/02/ PHKI_2000-2009_FWI_low-res.pdf Accessed 10 June 2014.

[GoI] Government of Indonesia. 1998. Peraturan Pemerintah Republik Indonesia nomor 59 tahun 1998 tentang tariff atas jenis penerimaan negara bukan pajak yang berlaku pada departemen kehutanan dan perkebunan. Jakarta. Indonesia.

Husson F, Josse J, Lê S and Mazet J. 2013. FactoMineR: multivariate exploratory data analysis and data mining with $\mathrm{R}, \mathrm{R}$ package version 1.24. 
Kartodihardjo H. 1999. Masalah kebijakan pengelolaan hutan alam produksi, Latin, Bogor.

Lentini M, Verissimo A and Sobral L. 2003. Fatos Florestais da Amazônia, Belém, Brazil: Imazon, available from: www.imazon.org.br.

Merry F, Amacher G, Nepstad D, Lima E, Lefebvre $P$ and Bauch S. 2006. Industrial development on logging frontiers in the Brazilian Amazon. Int. J. Sustainable Development, Vol. 9, No. 3, pp.277-296.

[MoF] Ministry of Forestry. 2007. Lampiran Peraturan Menteri Kehutanan No.P. 34/ Menhut-II/2007 tentang pedoman inventarisasi hutan menyeluruh berkala (IHMB) pada usaha pemanfaatan hasil hutan kayu pada hutan produksi. Jakarta. Indonesia.

[MoF] Ministry of Forestry. 2012. Data dan informasi pemanfaatan hutan tahun 2012. Direktorat Jenderal Planologi Kehutanan, Kementrian Kehutanan, Jakarta.

[MoF] Ministry of Forestry. 2014a. UndangUndang. http://www.dephut.go.id/index.php/ common/uud_filterby. Accessed 10 June 2014.

[MoF] Ministry of Forestry. 2014b. Statistik Kehutanan Provinsi. http://www.dephut.go.id/ index.php/news/otresults/1308. Accessed 10 June 2014.

[MoF] Ministry of Forestry. 2014c. Penutupan lahan dan fungsi kawasan hutan pada areal pemanfaatan hutan alam. Available at: http:// appgis.dephut.go.id/appgis/iuphhk.aspx.

[MoF] Ministry of Forestry. 2014d.Hasil SVLK. http://www.dephut.go.id/index.php/common/ vlk. Accessed 10 June 2014.

[MoF] Ministry of Forestry. 2014e. Hasil PHPL. http://www.dephut.go.id/index.php/common/ phpl. Accessed 10 June 2014.

Miteva D, Pattanayak S and P. Ferraro. 2012.

Evaluation of biodiversity policy instruments: What works and what doesn't? Oxford Review of Economic Policy 28: 69 -92.

Moore SE, Cubbage F and Eicheldinger C. 2012. Impacts of Forest Stewardship Council (FSC) and Sustainable Forestry Initiative (SFI) forest certification in North America. Journal of Forestry 110: 79-88.

Nebel G, Quevedo L, Bredahl Jacobsen J and Helles F. 2005. Development and economic significance of forest certification: the case of FSC in Bolivia. Forest Policy and Economics, 7(2), 175-186. doi:10.1016/ S1389-9341(03)00030-3

Newsom D and Hewit D. 2005. The global impacts of SmartWood certification. Final Report, TREES Program, Rainforest Alliance, Burlington, Vermont.

Peña-Claros, M., Blommerde, S. and Bongers, F. 2009. Assessing the progress made: an evaluation of forest management certification in the tropics. Tropical Resource Management Papers 95, Wageningen University, the Netherlands.

R Development Core Team. 2008. R: A language and environment for statistical computing. R Foundation for Statistical Computing, Vienna, Austria.

Rametsteiner E and Simula M. 2003. Forest certification - an instrument to promote sustainable forest management? Journal of Environmental Management 67: 87-98.

Romero C, Putz FE, Guariguata MR, Sills EO, Cerutti PO and Lescuyer G. 2013. An overview of current knowledge about the impacts of forest management certification: A proposed framework for its evaluation. Occasional Paper 91. CIFOR, Bogor, Indonesia.

Ruiz-Pérez M, de Blas DE, Nasi R, Sayer JA, Sassen M, Angoue C, Gami N, Ndoye O, Ngono G, Nguinguiri JC. et al. 2005. Logging in the Congo Basin: a multi-country characterization of timber companies. Forest Ecology and Management 214: 221-236.

Ruslandi, Klassen A, Romero C and Putz FE. 2014. Forest Stewardship Council Certification of Natural Forest Management in Indonesia: Required Improvements, Costs, Incentives, and Barriers. In: IUFRO-WFSE book "Forests under pressure: Local responses to global issues".

Thornber K, Plouvier D and Bass S. 2000. Certification: Barriers to benefits - A discussion of equity implications. Discussion Paper 8. European Forest Institute (EFI). Joensuu, Finland. 


\section{Appendix 1. Data Collection Matrix}

\begin{tabular}{|c|c|}
\hline Type of characteristic & Attribute \\
\hline \multicolumn{2}{|l|}{$\begin{array}{l}\text { Exogenous to the Parent } \\
\text { Company/FMU }\end{array}$} \\
\hline Economic & $\begin{array}{l}\text { Origin of parent company/FMU (country) } \\
\text { Origins of capital (country/ies) } \\
\text { Vertically integrated (parent company owns milling and other processing facilities: } \\
\text { YES/NO) } \\
\text { Publicly traded (YES/NO) } \\
\text { Multinational (YES/NO) }\end{array}$ \\
\hline Political & $\begin{array}{l}\text { Institutional regime (e.g., community, private, public) } \\
\text { Legal framework (e.g., new forest code; other influential regulations: YES/NO and date) } \\
\text { Political cohesion of industry sector }\end{array}$ \\
\hline \multicolumn{2}{|l|}{ Exogenous to the FMU } \\
\hline Biophysical & $\begin{array}{l}\text { Area (ha) } \\
\text { Slope: } \% \text { area }>10,20 \text { and } 30^{\circ} \\
\text { Previously logged (\%) } \\
\text { Distance or travel time to point of harbor/mill } \\
\text { Deforestation rate at the administrative corresponding level (e.g., district, municipality; } \\
\mathrm{km}^{2} / \text { period of time within the last } 10 \mathrm{yr} \text { ) }\end{array}$ \\
\hline Social/Livelihoods & $\begin{array}{l}\text { Local population density in surrounding area (e.g., district; municipality; } \# / \mathrm{km}^{2} \text { ) Population } \\
\text { dynamics (annual rate of change for the last } 10 \mathrm{yr} \text { ) } \\
\text { Dominant ethnic group(s) in area } \\
\text { Recognized resource use and tenure rights of local communities (YES/NO) } \\
\text { Existing conflicts with communities or other stakeholders (YES/NO) }\end{array}$ \\
\hline Economic & $\begin{array}{l}\text { Origin of FMU (country) } \\
\text { Origins of capital (country/ies) } \\
\text { Publicly traded (YES/NO) }\end{array}$ \\
\hline Political & $\begin{array}{l}\text { Institutional regime (e.g., community, private, public) } \\
\text { Legal framework (e.g., new forest code; other influential regulations: YES/NO and date) } \\
\text { Administration regime (e.g., district, state) } \\
\text { Type and duration of harvest permit }\end{array}$ \\
\hline \multicolumn{2}{|l|}{ Endogenous to the FMU } \\
\hline Biophysical & $\begin{array}{l}\text { Annual area logged }(\mathrm{ha} / \mathrm{yr}) \\
\text { Volume harvested } / \mathrm{yr}\left(\mathrm{m}^{3} / \mathrm{yr}\right) \\
\text { Logging intensity }\left(\mathrm{range} \text { and mean; } \mathrm{m}^{3} / \mathrm{ha}\right) \\
\text { \# species marketed }\end{array}$ \\
\hline Social/Livelihoods & $\begin{array}{l}\text { Workers: origin, gender (\#, \%) } \\
\text { Population density within the FMU } \\
\text { Population dynamics (annual rate of change for the last } 10 \mathrm{yr} \text { ) } \\
\text { Resident population not employed by FMU (i.e., family members of workers: \%) } \\
\text { Population illegally living in the FMU (\#) } \\
\text { Population dynamics (annual rate of change for the last } 10 \mathrm{yr}: \# / \text { period of time }\end{array}$ \\
\hline Economic & $\begin{array}{l}\text { Market orientation (principal outlet: Europe, North America, Asia) } \\
\text { Market proportion (\% national; \% export) } \\
\text { Logging subcontracted (YES/NO) }\end{array}$ \\
\hline Political & $\begin{array}{l}\text { Management status (certificate of legality, approved management plan, RIL-certified, no } \\
\text { official management status) } \\
\text { FMU responsible for providing social services to communities within/around (YES/NO) }\end{array}$ \\
\hline
\end{tabular}




\section{Appendix 2. List of People Contacted}

\begin{tabular}{|c|c|c|c|}
\hline No & Informants & Institutions & Sector/Stakeholder group \\
\hline 1 & Art Klassen & Tropical Forest Foundation & Certification coach/NGO \\
\hline 2 & Hasbillah & Tropical Forest Foundation & Certification coach/NGO \\
\hline 2 & Arya Hani & Tropical Forest Foundation/The Forest Trust & Certification coach/NGO \\
\hline 3 & Bayu Catur N & Tropical Forest Foundation/The Forest Trust & Certification coach/NGO \\
\hline 4 & Bambang W & The Nature Conservancy & Certification coach/NGO \\
\hline 5 & Yadi Kuswandana & The Forest Trust & Certification coach \\
\hline 6 & Rizky Permana & The Borneo initiative & Certification coach \\
\hline 7 & Thesis Budiarto & SCS & Certification body \\
\hline 8 & Gunung Wijanarko & SGS & Certification body \\
\hline 9 & Chisato & RA Smartwood & Certification body \\
\hline 10 & Oktovianus Rusmin & Mutu Agung Lestari/ Woodmark SA & Certification body \\
\hline 11 & Herman Prayudi & Indonesian concession Association & Timber association \\
\hline 12 & Heri Prayitno & Indonesian concession Association & Timber association \\
\hline 13 & Yudhi Hendro S & PT. Sari Bumi Kusuma & Forest concession \\
\hline 14 & Susilo Purnomo & PT. Sari Bumi Kusuma & Forest concession \\
\hline 15 & IBW Putera & Alas Kusuma group & Forest concession \\
\hline 16 & Gusti Ardiyansyah & Alas Kusuma group & Forest concession \\
\hline 17 & Eva Saefudin & PT. Sarpatim & Forest concession \\
\hline 18 & Syafrudin & PT. Erna Djuliawati & Forest concession \\
\hline 19 & Neneng S & Kayu Lapis Indonesia group & Forest concession \\
\hline 20 & Agus Prasodjo & PT. Erna Djuliawati & Forest concession \\
\hline 21 & Aris & Dwima Jaya Utama group & Forest concession \\
\hline 22 & Moch Amin & PT. Gemah Hutani Lestari & Forest concession \\
\hline 23 & Wahyul Ikhsani & PT. Ratah Timber & Forest concession \\
\hline 24 & Wuri Sutomo & PT. Memberamo Alas Mandiri & Forest concession \\
\hline 25 & Hidayat & Prima group & Forest concession \\
\hline 26 & Heri & PT. Timberdana & Forest concession \\
\hline 27 & Subhan & CV. Pangkar Begili & Forest concession \\
\hline 28 & Widiarso & Wapoga group & Forest concession \\
\hline
\end{tabular}

\section{Appendix 3. Data collected for typology study}

Excel Electronic file available upon request 


\section{Appendix 4. Cluster Composition}

Abbreviations for all following appendices. integrat. inte_no: non vertically integrated; inte_yes: vertically integrated. outlet: dom: domestic; exp: export; donexp: both markets. subcont. subc_yes: subcontracts exist; sub_no: no subcontracts. age: old: before 1998; new: after 1998.

\section{Cluster 1}

\begin{tabular}{|c|c|c|c|c|c|c|c|c|c|c|c|}
\hline Name & $\#$ & Area & PopDen & $\%$ Lim & Regime & Age & Integrat & Origin & Outlet & Subcont & Status \\
\hline Kop. Putra Dayak Jaya & 2 & 24610 & 1 & 100 & Private & New & Inte_NO & IND & DOM & Subc_YES & NEVER \\
\hline PT. Barito Putera & 7 & 42380 & 3 & 76 & Private & New & Inte_NO & IND & DOM & Subc_YES & NEVER \\
\hline PT. Bumimas Permata Abadi & 10 & 47700 & 4 & 100 & Private & New & Inte_NO & IND & DOM & Subc_YES & NEVER \\
\hline PT. Erythrina Nugraha Megah & 17 & 42762 & 12 & 50 & Private & New & Inte_NO & IND & DOM & Subc_YES & NEVER \\
\hline PT. Fitamaya Asmapara & 18 & 43880 & 3 & 85 & Private & New & Inte_NO & For & DOM & Subc_YES & NEVER \\
\hline PT. Fortuna Cipta Sejahtera & 19 & 53960 & 5 & 100 & Private & New & Inte_NO & For & DOM & Subc_YES & NEVER \\
\hline PT. Gaung Satya Graha Agrindo & 20 & 49950 & 3 & 72 & Private & New & Inte_NO & For & DOM & Subc_YES & NEVER \\
\hline PT. Hasnur Jaya Utama & 24 & 38445 & 50 & 53 & Private & New & Inte_NO & IND & DOM & Subc_YES & NEVER \\
\hline PT. Kahayan Terang Abadi & 30 & 42444 & 2 & 100 & Private & New & Inte_NO & IND & DOM & Subc_YES & NEVER \\
\hline PT. Karya Delta Permai & 33 & 79400 & 10 & 80 & Private & New & Inte_NO & For & DOM & Subc_YES & NEVER \\
\hline PT. Lestari Damai Indah Tbr & 37 & 10945 & 8 & 64 & Private & New & Inte_NO & IND & DOM & Subc_YES & NEVER \\
\hline PT. Menorah Loggingindo & 38 & 57830 & 1 & 100 & Private & New & Inte_NO & For & DOM & Subc_YES & NEVER \\
\hline PT. Mitra Perdana Palangka & 40 & 56000 & 1 & 100 & Private & New & Inte_NO & IND & DOM & Subc_YES & NEVER \\
\hline PT. Pemantang Abaditama & 42 & 49370 & 11 & 94 & Private & New & Inte_NO & IND & DOM & Subc_YES & NEVER \\
\hline PT. Sarana Piranti Utama & 46 & 49700 & 3 & 100 & Private & New & Inte_NO & For & DOM & Subc_YES & NEVER \\
\hline PT. Taman Raja Persada & 53 & 58500 & 5 & 100 & Private & New & Inte_NO & IND & DOM & Subc_YES & NEVER \\
\hline PT. Tingang Karya Mandiri & 54 & 44925 & 16 & 84 & Private & New & Inte_NO & IND & DomExp & Subc_YES & INTEREST \\
\hline PT. Trisetia Citagraha & 55 & 28200 & 10 & 40 & Private & New & Inte_NO & For & DOM & Subc_YES & NEVER \\
\hline PT. Wana Agung Asa Utama & 57 & 42750 & 8 & 60 & Private & New & Inte_NO & IND & DOM & Subc_YES & NEVER \\
\hline CV. Pari Jaya Makmur & 60 & 12730 & 16 & 67 & Private & New & Inte_NO & IND & DOM & Subc_YES & NEVER \\
\hline Kopontren Darussalam & 61 & 21690 & 10 & 50 & Private & New & Inte_NO & IND & DOM & Subc_YES & NEVER \\
\hline KSU.Mayang Putri Prima & 62 & 13110 & 18 & 100 & Private & New & Inte_NO & IND & DOM & Subc_YES & NEVER \\
\hline KSU.Meranti Tumbuh Indah & 63 & 15080 & 3 & 100 & Private & New & Inte_NO & IND & DOM & Subc_YES & NEVER \\
\hline KUD. Beringin Mulya & 64 & 39100 & 1 & 100 & Private & New & Inte_NO & IND & DOM & Subc_YES & NEVER \\
\hline PT. Aditya Kirana Mandiri & 66 & 42700 & 1 & 88 & Private & New & Inte_NO & IND & DOM & Subc_YES & INTEREST \\
\hline
\end{tabular}


Appendix 4. Continued

\begin{tabular}{|c|c|c|c|c|c|c|c|c|c|c|c|}
\hline Name & $\#$ & Area & PopDen & $\% \operatorname{Lim}$ & Regime & Age & Integrat & Origin & Outlet & Subcont & Status \\
\hline PT. Amindo Wana Persada & 68 & 43680 & 1 & 100 & Private & New & Inte_NO & IND & DOM & Subc_YES & INTEREST \\
\hline PT. Aquila Silva & 69 & 55300 & 1 & 100 & Private & New & Inte_NO & IND & DOM & Subc_YES & NEVER \\
\hline PT. Batu Karang Sakti & 72 & 47540 & 5 & 100 & Private & Old & Inte_NO & IND & DOM & Subc_YES & NEVER \\
\hline PT. Gunung Sidi Sukses Makmur & 80 & 34255 & 11 & 68 & Private & New & Inte_NO & IND & DOM & Subc_YES & NEVER \\
\hline PT. Hutani Kalimantan Abadi Permai & 83 & 35400 & 1 & 100 & Private & New & Inte_NO & IND & DOM & Subc_YES & NEVER \\
\hline PT. Indowana Arga Timber & 84 & 47800 & 3 & 90 & Private & New & Inte_NO & IND & DOM & Subc_YES & NEVER \\
\hline PT. Inhutani I (Unit Pangean) & 88 & 50230 & 3 & 100 & Public & Old & Inte_NO & IND & DOM & Subc_YES & INTEREST \\
\hline PT. Inhutani I (Unit Segah Hulu) & 91 & 54230 & 3 & 100 & Public & Old & Inte_NO & IND & DOM & Subc_YES & INTEREST \\
\hline $\begin{array}{l}\text { PT. Inhutani II (Malinau/lelang) } \\
\text {-Semamu }\end{array}$ & 94 & 71375 & 6 & 100 & Public & New & Inte_NO & IND & DOM & Subc_YES & INTEREST \\
\hline PT. Intertropic Aditama & 95 & 46230 & 2 & 59 & Private & New & Inte_NO & IND & DOM & Subc_YES & INTEREST \\
\hline PT. Karya Jaya Parakawan & 99 & 40000 & 14 & 100 & Private & Old & Inte_NO & IND & DOM & Subc_YES & NEVER \\
\hline PT. Karya Wijaya Sukses & 101 & 22320 & 1 & 65 & Private & New & Inte_NO & IND & DOM & Subc_YES & NEVER \\
\hline PT. Mardhika Insan Mulia (Unit Tabalar) & 106 & 25630 & 2 & 92 & Private & New & Inte_NO & IND & DOM & Subc_YES & INTEREST \\
\hline PT. Oceanias Timber Products & 113 & 67030 & 2 & 75 & Private & New & Inte_NO & IND & DOM & Subc_YES & NEVER \\
\hline PT. Panambangan & 114 & 43240 & 5 & 67 & Private & Old & Inte_NO & IND & DOM & Subc_YES & NEVER \\
\hline PT. Permata Borneo Abadi & 115 & 34000 & 2 & 100 & Private & Old & Inte_NO & IND & DOM & Subc_YES & NEVER \\
\hline PT. Rimba Makmur Sentosa & 120 & 43530 & 9 & 80 & Private & New & Inte_NO & IND & DOM & Subc_NO & NEVER \\
\hline PT. Rizki Kacida Reana & 122 & 29350 & 14 & 100 & Private & New & Inte_NO & IND & DOM & Subc_YES & INTEREST \\
\hline PT.Triwira Asta Barata & 137 & 53430 & 15 & 60 & Private & New & Inte_NO & IND & DOM & Subc_YES & NEVER \\
\hline PT. Utama Damai Indah Tbr & 138 & 49250 & 1 & 90 & Private & New & Inte_NO & IND & DOM & Subc_YES & NEVER \\
\hline PT. Wana Adiprima Mandiri & 139 & 33090 & 1 & 100 & Private & New & Inte_NO & IND & DOM & Subc_YES & NEVER \\
\hline PT. Wana Bhakti Persada & 140 & 44402 & 1 & 100 & Private & New & Inte_NO & IND & DOM & Subc_YES & NEVER \\
\hline PT. Wangsa Karya Lestari & 142 & 41530 & 1 & 83 & Private & New & Inte_NO & IND & DOM & Subc_YES & NEVER \\
\hline PT. Widya Artha Perdana & 143 & 14800 & 6 & 43 & Private & New & Inte_NO & IND & DOM & Subc_YES & NEVER \\
\hline CV. Bakti Dwipa Kariza & 144 & 11010 & 10 & 100 & Private & New & Inte_NO & IND & DOM & Subc_YES & NEVER \\
\hline CV. Pangkar Begili & 145 & 30195 & 10 & 87 & Private & New & Inte_NO & IND & DOM & Subc_NO & INTEREST \\
\hline PT. Harapan Kita Utama & 151 & 40500 & 2 & 100 & Private & New & Inte_NO & IND & EXPORT & Subc_YES & NEVER \\
\hline
\end{tabular}

continued on next page 
Appendix 4. Continued

\begin{tabular}{|c|c|c|c|c|c|c|c|c|c|c|c|}
\hline Name & $\#$ & Area & PopDen & $\% \operatorname{Lim}$ & Regime & Age & Integrat & Origin & Outlet & Subcont & Status \\
\hline PT. Karya Rekanan Bina Bersama & 155 & 43810 & 12 & 100 & Private & Old & Inte_NO & IND & DOM & Subc_YES & NEVER \\
\hline PT. Kusuma Atlas Timber & 157 & 45300 & 4 & 100 & Private & Old & Inte_NO & IND & DOM & Subc_YES & NEVER \\
\hline PT. Sewaka Lahan Sentosa & 161 & 32180 & 2 & 66 & Private & Old & Inte_NO & IND & DOM & Subc_YES & NEVER \\
\hline PT. Sinergi Bumi Lestari & 162 & 12770 & 17 & 100 & Private & New & Inte_NO & IND & DOM & Subc_YES & NEVER \\
\hline PT. Toras Banua Sukses & 164 & 24920 & 4 & 48 & Private & New & Inte_NO & IND & DOM & Subc_YES & NEVER \\
\hline PT. Borneo Karunia Mandiri & 167 & 12000 & 10 & 100 & Private & New & Inte_NO & IND & DOM & Subc_YES & NEVER \\
\hline
\end{tabular}

\section{Cluster 2}

\begin{tabular}{|c|c|c|c|c|c|c|c|c|c|c|c|}
\hline Name & $\#$ & Area & PopDen & $\%$ Lim & Regime & Age & Integrat & Origin & Outlet & Subcont & Status \\
\hline Kop. Mandau Talawang & 1 & 47700 & 8 & 0 & Private & New & Inte_NO & IND & DOM & Subc_YES & NEVER \\
\hline PT. Anugrah Alam Barito & 5 & 39500 & 8 & 0 & Private & New & Inte_NO & IND & DOM & Subc_NO & NEVER \\
\hline PT. Berkat Cahaya Timber & 8 & 124950 & 8 & 30 & Private & Old & Inte_NO & IND & DOM & Subc_NO & NEVER \\
\hline PT. Bina Multi Alam Lestari & 9 & 35000 & 40 & 0 & Private & New & Inte_NO & IND & DOM & Subc_YES & NEVER \\
\hline PT. Central Kalimantan Abadi & 12 & 40650 & 15 & 13 & Private & New & Inte_NO & IND & DOM & Subc_NO & NEVER \\
\hline PT. Dasa Intiga & 13 & 131850 & 8 & 0 & Private & Old & Inte_YES & IND & DOM & Subc_YES & INTEREST \\
\hline PT. Dwima Jaya Utama & 14 & 127300 & 6 & 20 & Private & Old & Inte_NO & IND & DomExp & Subc_YES & FSC \\
\hline PT. East Point Indonesia & 15 & 50665 & 7 & 0 & Private & New & Inte_NO & IND & DOM & Subc_YES & NEVER \\
\hline PT. Graha Sentosa Permai & 21 & 44970 & 3 & 13 & Private & New & Inte_NO & IND & EXPORT & Subc_YES & INTEREST \\
\hline PT. Hasil Kalimantan Jaya & 23 & 49500 & 11 & 0 & Private & New & Inte_NO & IND & DOM & Subc_YES & NEVER \\
\hline PT. Hutan Mulya & 26 & 52100 & 3 & 0 & Private & Old & Inte_NO & IND & DomExp & Subc_YES & INTEREST \\
\hline PT. Intrado Jaya Intiga & 29 & 51040 & 9 & 4 & Private & New & Inte_NO & IND & EXPORT & Subc_NO & NEVER \\
\hline PT. Joloy Mosak & 31 & 15575 & 40 & 0 & Private & New & Inte_NO & IND & DOM & Subc_YES & NEVER \\
\hline PT. Kayu Waja & 36 & 38450 & 3 & 40 & Private & Old & Inte_NO & IND & DomExp & Subc_YES & INTEREST \\
\hline PT. Meranti Mustika & 39 & 46829 & 5 & 45 & Private & Old & Inte_NO & IND & EXPORT & Subc_YES & NEVER \\
\hline PT. Pandu Jaya Gemilang Agung & 41 & 49500 & 21 & 0 & Private & New & Inte_NO & IND & DOM & Subc_YES & NEVER \\
\hline PT. Rangau Abdinusa & 44 & 29920 & 4 & 30 & Private & New & Inte_NO & IND & DOM & Subc_YES & NEVER \\
\hline PT. Rinanda Inti Lestari & 45 & 30160 & 7 & 3 & Private & New & Inte_NO & IND & DomExp & Subc_NO & NEVER \\
\hline PT. Sikatan Wana Raya & 50 & 49400 & 3 & 6 & Private & New & Inte_NO & IND & DOM & Subc_YES & NEVER \\
\hline
\end{tabular}


Appendix 4. Continued

\begin{tabular}{|c|c|c|c|c|c|c|c|c|c|c|c|}
\hline Name & $\#$ & Area & PopDen & \% Lim & Regime & Age & Integrat & Origin & Outlet & Subcont & Status \\
\hline PT. Sinergi Hutan Sejati & 52 & 68980 & 13 & 0 & Private & New & Inte_NO & IND & DOM & Subc_YES & INTEREST \\
\hline PT. Trisetia Intiga & 56 & 67070 & 9 & 36 & Private & New & Inte_NO & For & DOM & Subc_YES & NEVER \\
\hline PT. Wana Inti Kahuripan Intiga & 58 & 92475 & 5 & 55 & Private & Old & Inte_NO & IND & DOM & Subc_YES & INTEREST \\
\hline PT. Yakin Timber Jaya & 59 & 29126 & 4 & 45 & Private & Old & Inte_NO & IND & DOM & Subc_NO & NEVER \\
\hline PT. Adimitra Lestari & 65 & 52100 & 9 & 35 & Private & New & Inte_NO & IND & DOM & Subc_YES & INTEREST \\
\hline PT. Agro City Kaltim & 67 & 16470 & 3 & 38 & Private & New & Inte_NO & IND & DOM & Subc_YES & NEVER \\
\hline PT. Borneo Karya Indah Mandiri & 74 & 50860 & 5 & 0 & Private & New & Inte_NO & IND & DOM & Subc_YES & NEVER \\
\hline PT. Daisy Timber & 76 & 35886 & 2 & 0 & Private & Old & Inte_NO & IND & DomExp & Subc_YES & INTEREST \\
\hline PT. Greaty Sukses Abadi & 78 & 16865 & 10 & 0 & Private & Old & Inte_NO & IND & EXPORT & Subc_YES & NEVER \\
\hline PT. Hanurata Coy Ltd Periode II & 81 & 108650 & 2 & 0 & Private & Old & Inte_NO & IND & DOM & Subc_YES & NEVER \\
\hline PT. Harapan Kaltim Lestari & 82 & 44430 & 4 & 32 & Private & New & Inte_NO & IND & DOM & Subc_YES & NEVER \\
\hline PT. Inhutani I (Unit Kunyit -Simendurut) & 85 & 120760 & 5 & 35 & Public & Old & Inte_NO & IND & DOM & Subc_YES & INTEREST \\
\hline PT. Inhutani I (Unit Meraang) & 87 & 70700 & 2 & 50 & Public & Old & Inte_NO & IND & DOM & Subc_YES & INTEREST \\
\hline PT. Inhutani I (Unit Pimping) & 89 & 45480 & 4 & 45 & Public & Old & Inte_NO & IND & DOM & Subc_YES & INTEREST \\
\hline PT. Inhutani II (Unit Tanah Grogot) & 92 & 63200 & 6 & 5 & Public & Old & Inte_NO & IND & DOM & Subc_YES & INTEREST \\
\hline $\begin{array}{l}\text { PT. Inhutani II (Eks PT. Genwood)- } \\
\text { Sei Tubu }\end{array}$ & 93 & 99100 & 12 & 0 & Public & New & Inte_NO & IND & DOM & Subc_YES & INTEREST \\
\hline PT. Kedap Sayaaq & 102 & 18000 & 17 & 28 & Private & New & Inte_NO & IND & DOM & Subc_YES & NEVER \\
\hline PT. Mardhika Insan Mulia & 105 & 46080 & 1 & 20 & Private & New & Inte_NO & IND & DOM & Subc_YES & INTEREST \\
\hline PT. Marimun Timber \& Industries & 107 & 73625 & 18 & 0 & Private & Old & Inte_NO & IND & EXPORT & Subc_NO & NEVER \\
\hline PT. Nadila Indodaya & 111 & 44090 & 5 & 0 & Private & New & Inte_NO & IND & DOM & Subc_YES & NEVER \\
\hline PT. Puji Sempurna Raharja & 116 & 51000 & 5 & 0 & Private & Old & Inte_NO & IND & DOM & Subc_YES & NEVER \\
\hline PT. Rimba Karya Rayatama & 118 & 40630 & 5 & 0 & Private & New & Inte_YES & IND & EXPORT & Subc_NO & NEVER \\
\hline PT. Rizki Kacida Reana & 123 & 55150 & 3 & 49 & Private & New & Inte_NO & IND & DOM & Subc_YES & INTEREST \\
\hline PT. Seroja Universum Narwastu & 127 & 36500 & 3 & 0 & Private & New & Inte_NO & IND & EXPORT & Subc_NO & NEVER \\
\hline PT. Sylvia Ery Timber & 133 & 56000 & 3 & 0 & Private & Old & Inte_NO & IND & DOM & Subc_YES & NEVER \\
\hline PT. Telakai Mandiri Sejahtera & 135 & 12320 & 42 & 0 & Private & New & Inte_NO & IND & DOM & Subc_YES & NEVER \\
\hline PT. Lanjak Deras Jaya Raya & 158 & 45740 & 5 & 0 & Private & Old & Inte_NO & IND & DOM & Subc_YES & NEVER \\
\hline PT. Mohairson Pawan Khatulistiwa & 159 & 48440 & 18 & 0 & Private & Old & Inte_NO & IND & DOM & Subc_YES & NEVER \\
\hline
\end{tabular}


Appendix 4. Continued

\begin{tabular}{|c|c|c|c|c|c|c|c|c|c|c|c|}
\hline Name & $\#$ & Area & PopDen & $\% \operatorname{Lim}$ & Regime & Age & Integrat & Origin & Outlet & Subcont & Status \\
\hline PT. Elbana Abadi Jaya & 169 & 15480 & 40 & 0 & Private & New & Inte_NO & IND & DOM & Subc_YES & NEVER \\
\hline PT. Inhutani II (Unit Pulau Laut) & 170 & 40950 & 40 & 0 & Private & Old & Inte_NO & IND & DOM & Subc_YES & INTEREST \\
\hline PT. Kodeco Timber & 171 & 99570 & 60 & 0 & Private & Old & Inte_NO & IND & DOM & Subc_NO & NEVER \\
\hline \multicolumn{12}{|l|}{ Cluster 3} \\
\hline Name & $\#$ & Area & PopDen & $\% \operatorname{Lim}$ & Regime & Age & Integrat & Origin & Outlet & Subcont & Status \\
\hline PT. Akhates Plywood & 3 & 94380 & 1 & 100 & Private & Old & Inte_YES & IND & DOM & Subc_YES & INTEREST \\
\hline PT. Amprah Mitra Jaya & 4 & 77700 & 3 & 78 & Private & New & Inte_NO & IND & DOM & Subc_NO & NEVER \\
\hline PT. Carus Indonesia & 11 & 73281 & 4 & 100 & Private & Old & Inte_NO & IND & DomExp & Subc_YES & INTEREST \\
\hline PT. Gunung Meranti & 22 & 95265 & 4 & 95 & Private & Old & Inte_NO & IND & EXPORT & Subc_YES & NEVER \\
\hline PT. Hutan Domas Raya & 25 & 99870 & 2 & 90 & Private & Old & Inte_NO & IND & DomExp & Subc_YES & NEVER \\
\hline PT. Hutanindo Lestari Raya Timber & 27 & 98000 & 9 & 100 & Private & Old & Inte_NO & For & DomExp & Subc_YES & INTEREST \\
\hline PT. Indexim Utama Corp. & 28 & 52480 & 2 & 87 & Private & Old & Inte_YES & IND & EXPORT & Subc_NO & FSC \\
\hline PT. Karda Trades & 32 & 98400 & 10 & 100 & Private & Old & Inte_NO & For & DomExp & Subc_YES & NEVER \\
\hline PT. Kayu Ara Jaya Raya & 34 & 85210 & 1 & 100 & Private & Old & Inte_NO & IND & DOM & Subc_NO & NEVER \\
\hline PT. Kayu Tribuana Rama & 35 & 73017 & 8 & 79 & Private & Old & Inte_NO & IND & DOM & Subc_NO & INTEREST \\
\hline PT. Praba Nugraha Tech. & 43 & 42600 & 21 & 95 & Private & New & Inte_NO & IND & EXPORT & Subc_NO & NEVER \\
\hline PT. Sarang Sapta Putra & 47 & 51100 & 1 & 100 & Private & Old & Inte_YES & IND & EXPORT & Subc_NO & INTEREST \\
\hline PT. Sindo Lumber & 51 & 36215 & 7 & 44 & Private & Old & Inte_YES & IND & EXPORT & Subc_NO & INTEREST \\
\hline PT. Barito Nusantara Indah & 71 & 94685 & 18 & 93 & Private & Old & Inte_NO & IND & DomExp & Subc_YES & NEVER \\
\hline PT. Belayan River Timber & 73 & 97500 & 1 & 100 & Private & Old & Inte_YES & IND & DomExp & Subc_NO & FSC \\
\hline $\begin{array}{l}\text { PT. Civika Wana Lestari (Eks PT. } \\
\text { Damukti) }\end{array}$ & 75 & 53000 & 2 & 87 & Private & Old & Inte_YES & IND & DomExp & Subc_NO & INTEREST \\
\hline PT. Gunung Gajah Abadi & 79 & 81000 & 16 & 54 & Private & Old & Inte_NO & IND & DOM & Subc_NO & EN ROUTE \\
\hline PT. Inhutani I (Unit Labanan) & 86 & 138210 & 10 & 66 & Public & Old & Inte_NO & IND & DOM & Subc_YES & EN ROUTE \\
\hline PT. Inhutani I (Unit Sambarata) & 90 & 106020 & 2 & 82 & Public & Old & Inte_NO & IND & DOM & Subc_YES & INTEREST \\
\hline PT. Jaya Timber Trading & 98 & 53200 & 16 & 70 & Private & Old & Inte_NO & IND & EXPORT & Subc_YES & NEVER \\
\hline PT. Karya Lestari & 100 & 47063 & 1 & 88 & Private & Old & Inte_NO & IND & EXPORT & Subc_NO & NEVER \\
\hline PT. Kedungmadu Tropical Wood & 103 & 50400 & 5 & 55 & Private & Old & Inte_NO & IND & EXPORT & Subc_NO & NEVER \\
\hline PT. Kemakmuran Berkah Timber & 104 & 82810 & 1 & 100 & Private & Old & Inte_YES & IND & EXPORT & Subc_NO & FSC \\
\hline
\end{tabular}


Appendix 4. Continued

\begin{tabular}{|c|c|c|c|c|c|c|c|c|c|c|c|}
\hline Name & $\#$ & Area & PopDen & $\% \operatorname{Lim}$ & Regime & Age & Integrat & Origin & Outlet & Subcont & Status \\
\hline PT. Melapi Timber & 108 & 78300 & 1 & 77 & Private & Old & Inte_NO & IND & EXPORT & Subc_NO & NEVER \\
\hline PT. Meranti Sakti Indonesia & 109 & 46200 & 2 & 70 & Private & Old & Inte_NO & IND & EXPORT & Subc_NO & NEVER \\
\hline PT. Mutiara Kalja Permai & 110 & 65875 & 1 & 100 & Private & Old & Inte_NO & IND & DOM & Subc_NO & NEVER \\
\hline PT. Narkata Rimba & 112 & 41540 & 3 & 100 & Private & Old & Inte_YES & IND & DomExp & Subc_NO & FSC \\
\hline PT. Rimba Karya Rayatama & 119 & 143970 & 3 & 100 & Private & New & Inte_YES & IND & EXPORT & Subc_NO & NEVER \\
\hline PT. Rimba Sempana Makmur & 121 & 27425 & 1 & 70 & Private & Old & Inte_YES & IND & DOM & Subc_NO & NEVER \\
\hline PT. Sarana Trirasa Bhakti & 125 & 35090 & 1 & 82 & Private & Old & Inte_YES & IND & DomExp & Subc_NO & INTEREST \\
\hline $\begin{array}{l}\text { PT. Segara Indochem \& PT. Segara } \\
\text { Timber }\end{array}$ & 126 & 85725 & 2 & 80 & Private & Old & Inte_NO & IND & EXPORT & Subc_NO & NEVER \\
\hline $\begin{array}{l}\text { PT. Sumalindo Lestari Jaya IV (eks PT. } \\
\text { Madyakara Pacific) }\end{array}$ & 129 & 63550 & 1 & 100 & Private & Old & Inte_YES & IND & EXPORT & Subc_NO & EN ROUTE \\
\hline PT. Sumalindo Lestari Jaya V & 130 & 59066 & 1 & 100 & Private & New & Inte_YES & IND & EXPORT & Subc_NO & INTEREST \\
\hline PT. Sumalindo Lestari Jaya Tbk & 131 & 69765 & 1 & 97 & Private & New & Inte_YES & IND & EXPORT & Subc_NO & INTEREST \\
\hline PT. Sumber Mas Timber & 132 & 53400 & 1 & 89 & Private & Old & Inte_NO & IND & EXPORT & Subc_NO & NEVER \\
\hline PT. Telagamas Kalimantan & 134 & 124675 & 14 & 69 & Private & Old & Inte_NO & IND & DOM & Subc_YES & NEVER \\
\hline PT. Timber Dana & 136 & 76340 & 5 & 100 & Private & Old & Inte_NO & IND & DOM & Subc_YES & INTEREST \\
\hline PT. Wana Rimba Kencana & 141 & 65000 & 1 & 100 & Private & Old & Inte_NO & IND & DOM & Subc_NO & INTEREST \\
\hline PT. Batasan & 146 & 49150 & 7 & 100 & Private & Old & Inte_NO & IND & DOM & Subc_NO & NEVER \\
\hline PT. Benua Indah & 147 & 51300 & 10 & 92 & Private & Old & Inte_NO & IND & EXPORT & Subc_NO & NEVER \\
\hline PT. Bina Ovivipari Semesta & 148 & 10100 & 16 & 100 & Private & New & Inte_YES & IND & EXPORT & Subc_NO & INTEREST \\
\hline PT. Bumi Raya Utama Wood Industry & 149 & 110500 & 13 & 100 & Private & Old & Inte_NO & IND & EXPORT & Subc_NO & NEVER \\
\hline PT. Duaja Corp. II & 150 & 74860 & 2 & 96 & Private & Old & Inte_NO & IND & DOM & Subc_NO & NEVER \\
\hline PT. Kalimantan Satya Kencana-Add & 152 & 48000 & 12 & 100 & Private & Old & Inte_NO & IND & DOM & Subc_NO & NEVER \\
\hline PT. Kandelia Alam & 153 & 18130 & 27 & 100 & Private & New & Inte_YES & IND & EXPORT & Subc_NO & INTEREST \\
\hline PT. Karunia Hutan Lestari & 154 & 41700 & 2 & 100 & Private & Old & & IND & DomExp & Subc_NO & EN ROUTE \\
\hline PT. Kawedar Wood Industry & 156 & 69050 & 6 & 100 & Private & Old & Inte_NO & IND & DOM & Subc_NO & NEVER \\
\hline PT. Sari Bumi Kusuma (Kalbar) & 160 & 75200 & 6 & 100 & Private & Old & Inte_YES & IND & EXPORT & Subc_NO & EN ROUTE \\
\hline PT. Wana Kayu Batu Putih & 165 & 42500 & 8 & 95 & Private & Old & Inte_YES & IND & DOM & Subc_NO & NEVER \\
\hline PT. Wanasokan Hasilindo & 166 & 49000 & 8 & 100 & Private & Old & Inte_YES & IND & EXPORT & Subc_NO & EN ROUTE \\
\hline PT. Aya Yayang Indonesia & 168 & 87241 & 32 & 75 & Private & Old & Inte_NO & IND & EXPORT & Subc_NO & INTEREST \\
\hline
\end{tabular}




\section{Appendix 5. Description of variables not used in analyses}

1. \% Natural Forests in FMUs

Range 0-92\%.; Median: 9.7

Distribution of \% Natural Forests in Indonesian FMUs

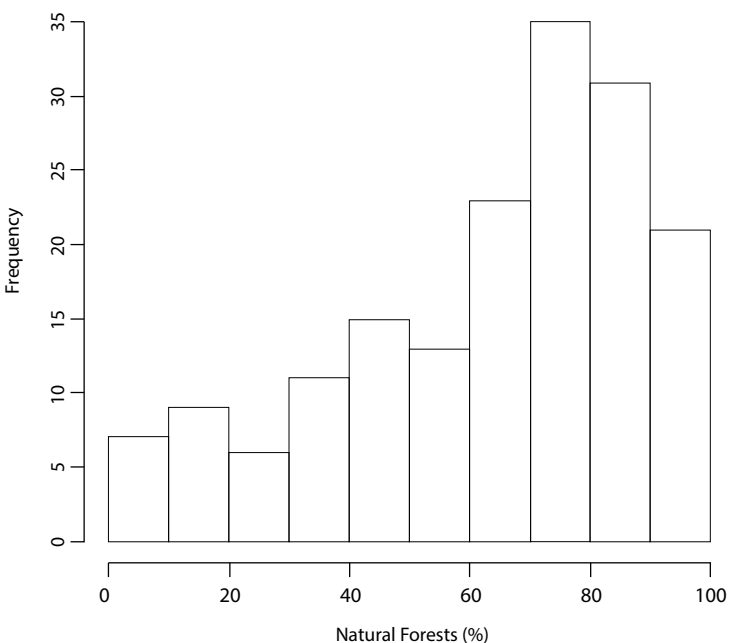

2. Management Practices

FSC: 7.01\%; IFM: 25.7 \%; PHP: $29.8 \%$; SVLK: $37.4 \%$

3. \% Logged of each FMU

Range 0-100\%.; Mean: 65.1

Distribution of \% Logged Area of Indonesian FMUs

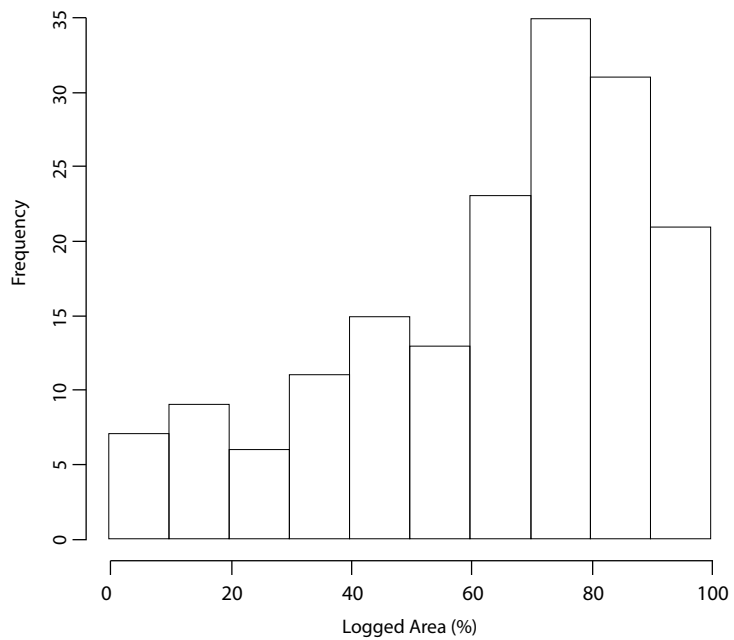

4. Population Densities in FMUs

Range: 1-84 inhabitants ha-1; Median: 8

Population Densities in Indonesian FMUs

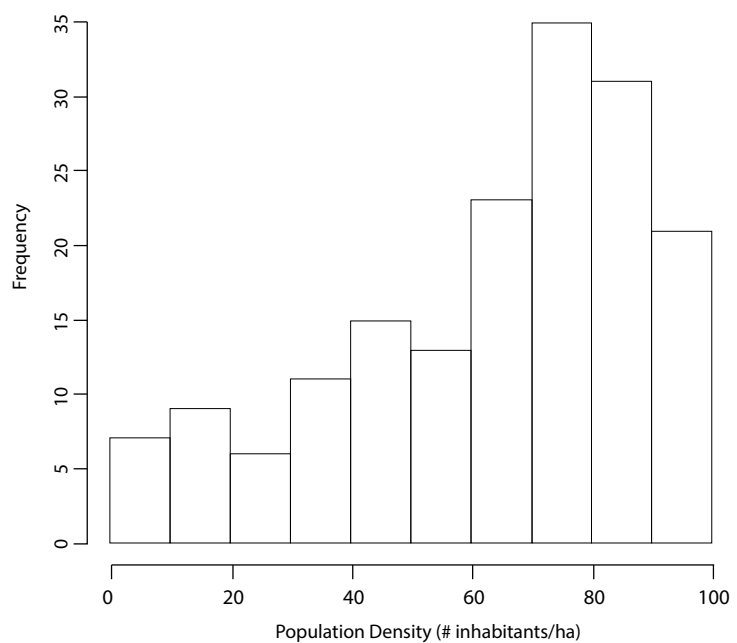

5. Population Growth at the District Level for FMUs

Range: $-0.3-5.9$ inhabitants yr-1; Mean: 2.77

Population Growth in Indonesian FMUs

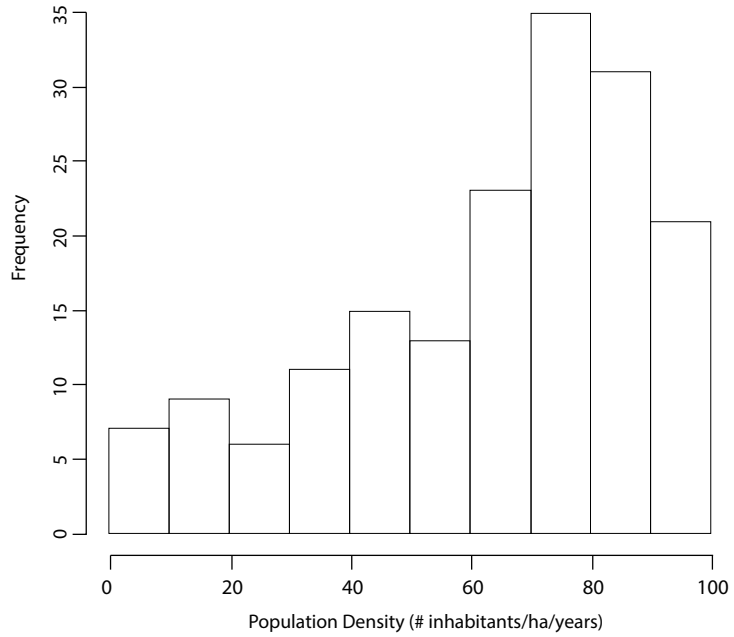

6. Ethnic groups within and around FMUs Dayak: 95.3\%: Banjur: 2.9\%; Banjar and Kutai: $1.7 \%$ 
Appendix 5. Continued

\section{Permit Duration}

\begin{tabular}{cr}
\hline Permit Duration (years) & $\%$ \\
\hline 15 & 0.6 \\
20 & 65.1 \\
35 & 0.6 \\
45 & 24.6 \\
55 & 8.3 \\
70 & 1.3 \\
\hline
\end{tabular}

\section{Publicly Traded}

YES: 4.6\%; NO: $95.4 \%$ 


\title{
Dynamics along the Natural Forest Certification Continuum
}

\author{
Ruslandi
}

\subsection{Introduction}

Although voluntary, marked-based forest certification as a strategy for conserving natural tropical forests has been underway for more than two decades, field-based assessments of its impacts are scarce at least partially because such evaluations are costly, time consuming, and methodologically challenging (Peña-Claros et al. 2009, Moore et al. 2012, Romero et al. 2013). Unfortunately, seemingly straightforward comparisons between certified and uncertified forest management units (FMUs) are prone to be biased because well-run
FMUs are more likely to seek certification (Romero and Castrén 2013). Furthermore, such comparisons fail to recognize that at different times, FMUs can be at different stages along the process of becoming certified, which is generally reflected in different forest management practices (Figure 4.1). Thus, understanding where FMUs are on the certification continuum and the influence of different factors on selfselection into certification are fundamental for the design of appropriate evaluations and particularly, for counterfactual establishment.

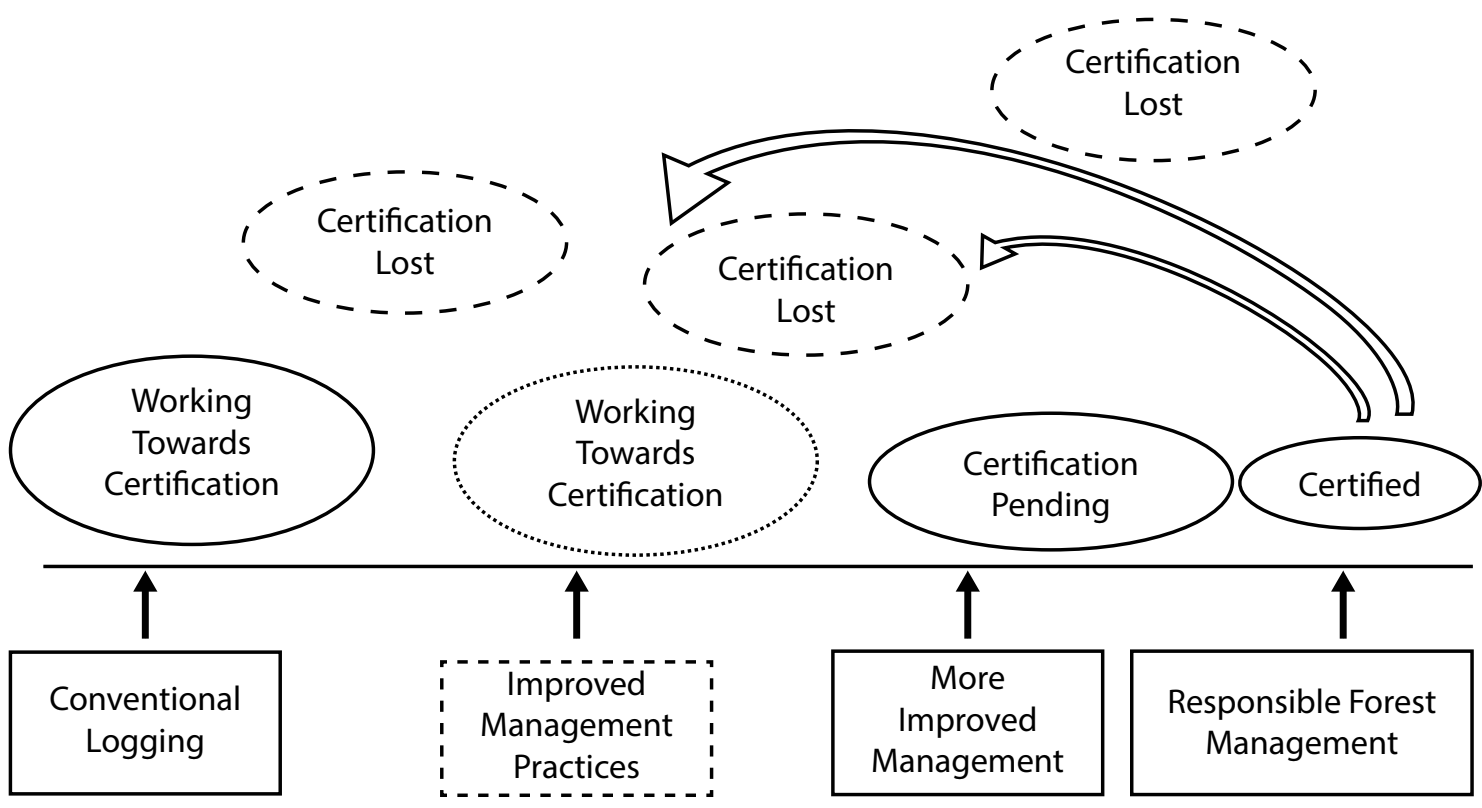

Forest Values

Maintained

Figure 4.1. Certification continuum depicted as a stylized series of states superimposed on an axis that represents increasing responsibility of forest management and progression towards certification (ovals). Once an FMU loses certification, its location on the management axis will depend on management practices employed (adapted from Romero et al. 2013). 
Obtaining forest certification typically involves gradual adoption of a number of improvements in forest management (Ruslandi et al. 2014). Simply classifying an FMU as un-certified when it is already well on its way towards becoming certified will cause the impacts of certification to be underestimated. In the case of Indonesia, a detailed study that tracked the costs and pathways to certification of five concessions in Kalimantan determined that the granting of Forest Stewardship Council (FSC) certification took 3 to 10 years after initiation of formal efforts to obtain that status (Ruslandi et al. 2014). Now that FMUs in Indonesia are required to meet a mandatory certification standard set by the government ${ }^{1}$, regardless of their interest on voluntary certification, the pathway to FSC certification may be shorter because some of the requirements will already have been met. On the other hand, FSC certified FMUs are typically required to continue to improve their practices even after being certified, thus time certified may also influence management performance and needs to be considered in counterfactual selection.

To clarify the dynamics along the certification continuum in Indonesia, we consider how the population of FMUs has changed over time. Knowing the time-sensitive structure of this population will provide a basis for selection of equivalent FMUs for comparison in an impact evaluation study. We contextualize the observed dynamics along the certification continuum through consideration of contemporaneous political and economic developments related to the forest and timber sectors in the country. Using the focal times from a political economy study of the Indonesian forestry sector developed in parallel (Chapter 2, this volume) and information provided by other researchers (e.g., Barr et al. 2006, Gellert 2010, Tambunan 2010), we assess whether there are time-specific trends in certification dynamics over the period of 1996-2013 and propose some plausible hypotheses to be further tested during field evaluations of FSC impacts in Indonesia.

While we acknowledge that political and economic developments are both perceived and responded differently by various stakeholders at also different points in time, we explore how major events affected forest industries in general and certification in particular. We also recognize that some of

1 MoF's mandatory certification of concession performance (Pengelolaan Hutan Produksi Lestari - PHPL) is conducted by independent certification bodies (Lembaga Penilai IndependenLPI) endorsed by MoF. these perceived reactions might be secondary or indirect in nature. For example, certification might have been less affected by the political event of decentralization than by the widespread illegal logging activities that ensued soon after this policy shift. The cause-effect relationships proposed between certification and national and international political and economic events therefore need to be considered as hypotheses, but hopefully plausible ones. The important relationships between the realized certification dynamics and particular FMU characteristics are treated in Chapter 3. Here we document the temporal changes in the FMU population according to where they rest along the certification continuum. We specifically assess whether dominant transitions among the certification stages correspond with national political and economic changes in timber markets. We hope that this analysis will lead to insights about the sorts of political and/or economic factors required to promote improved forest management and certification in Indonesia and elsewhere, once empirical impacts of FSC certification are assessed.

Specific questions addressed here include:

a. How did the population of active FMUs change over time?

b. How did the number and proportion of FMUs that were certified, considering certification, or en route to certification change over time?

c. How did the number and proportion of FMUs that failed in their attempts to obtain certification, were successfully certified, retained their certification, or lost their certification change over time?

d. What steps did the FMUs that lost certification take in response to this change in status and when were these steps taken?

e. Of the FMUs that failed to obtain certification, how many abandoned the process completely, how many later pursued certification, and how many years elapsed between these decisions?

In regards to the certifying bodies (CBs) involved in certification in Indonesia tracked over the 19962013 period, we consider their activities related to natural forest management certification. The specific questions about $\mathrm{CBs}$ addressed are:

a. Which CBs are associated with FMUs getting certified, remaining certified, and/or losing certification, and at what times?

b. If FMUs switched certification schemes and CBs, when did these shifts occur and in which directions? 


\subsection{Methods}

To capture the dynamics along the certification continuum through time, we employed a more detailed version of the generic model proposed by Romero et al. 2013 (Figure 4.2). The steps and rules for transitions among certification and operational states are explained in Table 4.1.

\subsubsection{Data collection}

Four kinds of data were collected for the 19962013 period:

1. FMUs (concessions) status: Number of active, expired, and new FMUs on yearly basis. Data were extracted from MoF databases (MoF 2001,
2003, 2006, 2008, 2009, 2011,2012,2013) and complemented with information from APHI and certification coaches (Tropical Forest Foundation -TFF; The Forest Trust -TFT; The Nature Conservancy-TNC; The Borneo Initiative-TBI; and World Wildlife Fund for Nature -WWF) ${ }^{2}$.

2. FMUs considering forest certification: Indicated by the interest of FMUs to implement improved forest management (IFM) and/or to seek certification. Data were collected from numerous published and institutional sources including records from forest managementrelated development projects (e.g., NRMPUSAID, ITFMP-UK, BFMP-EU, SCKPFPEU, SFMP-GiZ; Appendix I)

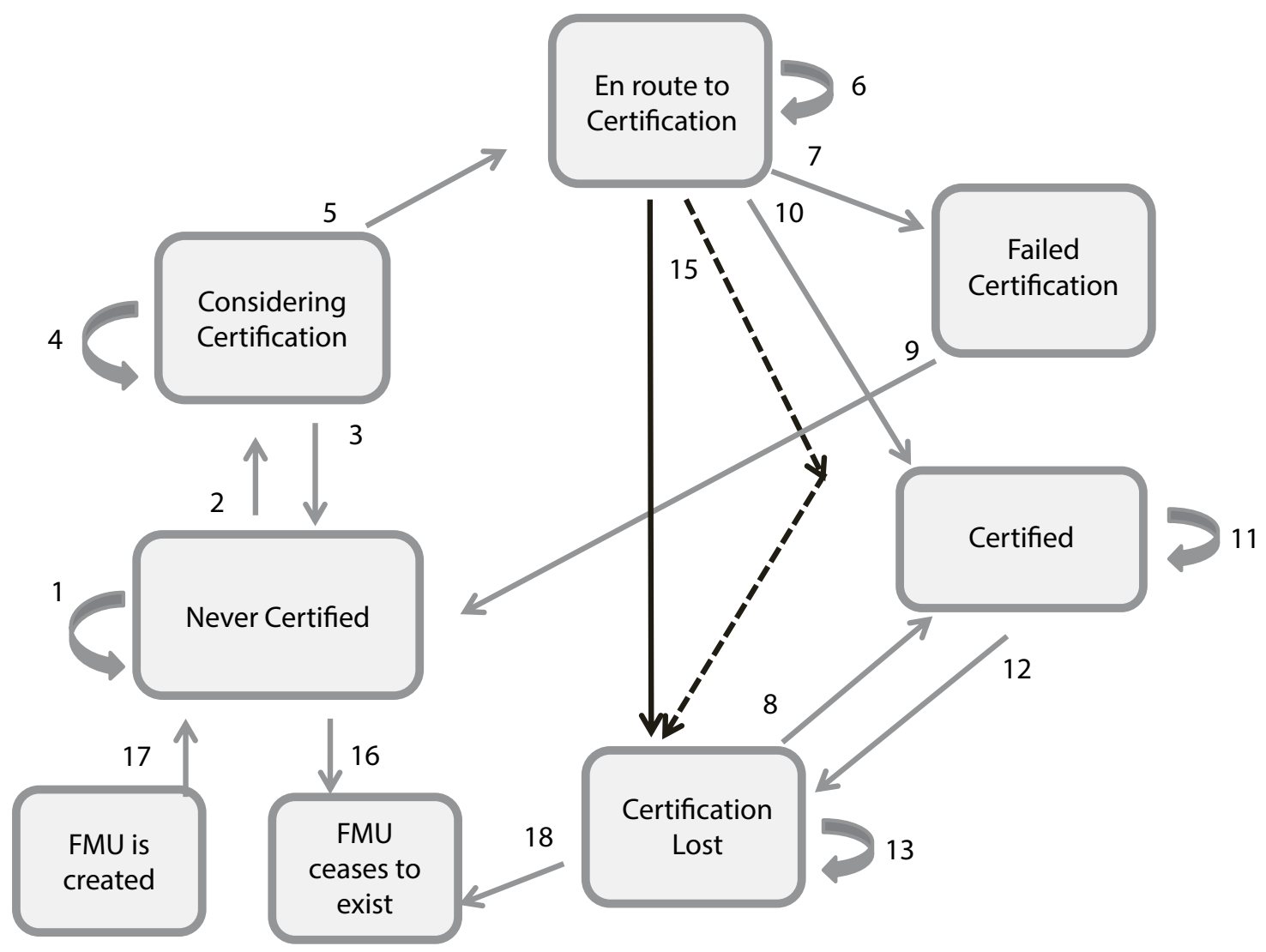

Figure 4.2. Transitions (numbered arrows) between stages along the certification continuum observed at annual intervals. Also included are transitions that reflect FMUs that ceased to operate. See Table 4.1 for explanations of each transition. Among the possible transitions, only those observed in Indonesia during 1996-2013 are included.

2 These organizations secured funding to support training activities and otherwise sponsor FMUs to improve forest management and advance towards certification (See Appendix I for details about each program). 
Table 4.1. Rules for assigning FMUs to different stages (indicated in italics in this table) along the certification continuum and for the transitions between those stages, as depicted in Figure 4.1.

\begin{tabular}{ll}
\hline Decision & Description \\
\hline 1 & An FMU that remains uncertified remains in never certified. \\
2 & $\begin{array}{l}\text { If an FMU contacted a certifying body or an organization that offers forest management training } \\
\text { related to certification (e.g., TBI, TFF, TFT, TNC, WWF, APHI or donor- funded projects), or participated } \\
\text { in such capacity-building activities it enters considering certification. }\end{array}$ \\
3 & $\begin{array}{l}\text { After an FMU has been in considering certification for }>3 \text { years during which it participates in no } \\
\text { certification-related activities it reverts to never certified. }\end{array}$ \\
4 & An FMU can remain in considering certification for maximum 3 years unless there is evidence of \\
5 & further progress towards certification (e.g., development of pre- and/or full assessments taking D5). \\
6 & An FMU completes a pre- and/or a full assessment with a certifying body). \\
7 & An FMU can stay in en route to certification for maximum 5 yr if it does not become certified. \\
8 & An FMU that remains $>5$ yr in en route to certification goes to Failed Certification. \\
9 & An FMU that lost certification gets certified again within the same year. \\
10 & If an FMU in failed certification does not get a pre- or a full assessment in at least 3 yr of entering that \\
11 & stage it goes to never certified. \\
12 & An FMU is certified. \\
13 & An FMU remains certified or is re-certified (i.e., certificates are valid for 5 years unless an annual audit \\
15 & reveals problems). \\
16 & An FMU loses certification. \\
17 & The FMU remains in certification lost without further attempts at certification. \\
18 & An FMU gets certified but then loses certification in the same year. \\
& An FMU that was never certified ceases to exist. \\
& An FMU is created.
\end{tabular}

and institutional data from the Indonesian forest concessionaires program (APHI) on the SFM standard field testing. We assumed that some FMUs that eventually proceeded to the formal certification stage were considering certification. The decisions associated with this interest in implementation include written records signaling that the FMU started to participate in improved forest management and/or certification assistance programs run by organizations such as TFF, TFT, TNC, WWF and TBI. Such activities include participation in SFM training activities (e.g., IFM; voluntary legal verification; certification assistance; training on RIL; etc.).

(http://www.tff-indonesia.org/index.php/mapof-tff-activity/training-activities-68341; http:// www.tft-forests.org/projects/portfolio.asp, http://www.theborneoinitiative.org/partnerorganisations/forest-enterprises; http://www. wwf.or.id/program/inisiatif/gftnindonesia/ profil_perusahaan/index.cfm?uPage=2); Natural Capital Advisors 2011).

3. FMUs entering the formal process of certification: Data include FMUs that had a certification pre-assessment by a CB and that took further steps towards acquiring certification. Information from internal records from CBs and FMUs were used along with FSC and LEI websites to determine the dates of assessments and any changes in certification status.

(FSC 2014; http://info.fsc.org/certificate. php\#result and LEI 2014; http://www.lei. or.id/files/FMU\%20\&\%20Manufacture $\% 20$ certified\%20LEI_July\%202013.pdf)

4. FMUs certification status (gained and lost/ suspended/terminated): Information obtained from FSC records available at www.info.fsc.org, verified with information from $\mathrm{CB}$ websites. 


\subsubsection{Data interpretation and analyses}

The protocols used to define certification stages and annual transitions are explained in Figure 4.2 and Table 4.1. When more than one transition occurred in a single year, we used the transition that led to the most advanced stage relative to the previous year (e.g., certification lost is a more advanced stage than certified). This assumption is justified by the fact that a FMU needs to be certified before it can lose its certificate and, furthermore, it takes at least 10 months to become officially certified once the assessments are completed.

The total number of FMUs includes firms with active permits which fluctuates due to creation of new FMUs (although these might be operating in already established concessions) and closure/cessation of operations of others due to expiration or revocation of concession permits. After concessions are revoked or expired, the MoF may allocate them to non-forest land uses (e.g., agriculture, conversion to plantation). In the case of abandoned concessions, the MoF allocates logging or other rights to other firms. Note that if an FMU does not harvest timber over a 3-year period, its permit is revoked by the MoF, but the regulation does not specify the minimum amount of timber that needs to be harvested to keep a permit active.

Because the total number of active FMUs varies through time (e.g., some FMUs were created while others ceased to operate), the frequencies of FMU transitions are expressed on an annual basis as the proportion of FMUs that existed in the source stage at the beginning of the previous year (e.g., proportion of FMUs that remained in never certified stage as a function of the number of FMUs in that stage the year before).

For statistical analyses it was assumed that the probabilities of transitions among stages along the certification continuum (i.e., decisions vis-a-vis certification) followed a multinomial distribution (i.e., FMUs had at least 2 but often more choices; Figure 4.2). Likelihood ratio tests (LRT) for a multinomial distribution were performed to test the null hypothesis of no difference among the probabilities of these transitions for each year for each decision that leads an FMU to stay in the same stage or move to another along the continuum. In addition, simultaneous confidence intervals (CI) for linked decision probabilities were calculated using the package Multinomial CI (Villacorta 2014). All statistical analyses were conducted in $\mathrm{R}(\mathrm{R}$ Development Core Team 2008).

\subsection{Results}

\subsubsection{Population dynamics of forest management units (FMUs)}

The total number of FMUs in natural forests in Indonesia declined markedly from a high of 447 in 1996 to a low of 267 in 2002, when FMU expiration peaked at 82 , after which it stabilized at about 300 active FMUs (Figure 4.3A). In terms of FMU area, the pattern was different. Total FMU area tended to decrease over time from 1996 - 2013 and the largest FMU decline was observed in 1999 (Figure 4.3B).

Creation of new FMUs occurred sporadically starting in 1999 and peaked in 2006 for both number of FMUs and FMUs area. The different temporal patterns displayed by the number of FMUs and FMU area is explained by the fact that FMUs which ceased operations were mostly large ( $\geq 100,000 \mathrm{ha}$ ) while the newly created FMUs were smaller. This situation was due partly to the implementation of government regulation 6/1999, which limited FMUs to 50,000 ha (Ruslandi et al. 2014). It is believed that prior to 1999 the relative political stability in terms of the legal frameworks for forested lands caused the timber harvesting business to restrict new players. In contrast and as observed, the establishment of new FMUs started during the initial years of the reformation and decentralization era (i.e., post 1999). Unfortunately, during this same period, massive illegal logging rendered legal activities less attractive, which resulted in the abandonment and expiration of many FMUs. This pattern changed in 2006 when the MoF started to grant new FMUs that were created based on the Bupati Decree ${ }^{3}$.

It should also be noted that an equal number of FMUs established on the basis of the Bupati Decree were terminated due to their failure to fulfill the verification requirements of the MoF (Ruslandi et al. 2014). Thereafter, the number of FMUs was relatively constant. By 2013 , $65 \%$ of the 285 FMUs (39\% of the FMU area of 22.7 million ha) were created during the post-Soeharto era (1999-2013; Figs. 4A and 4B). One possibility is that with the start of the reformation era in 1998, at least some forest industries closely linked to the Soeharto regime collapsed and were replaced by other business players (for a contrasting view, see Gellert 2010).

3 Bupati Decree: The MoF revoked the authority of provincial and district governments to grant logging rights. As a consequence all concessions granted based on the Bupati Decree should undergo the verification process by the MoF in 2005-2006. If these concessions pass the verification then their permit will be replaced with the MoF Decree. 

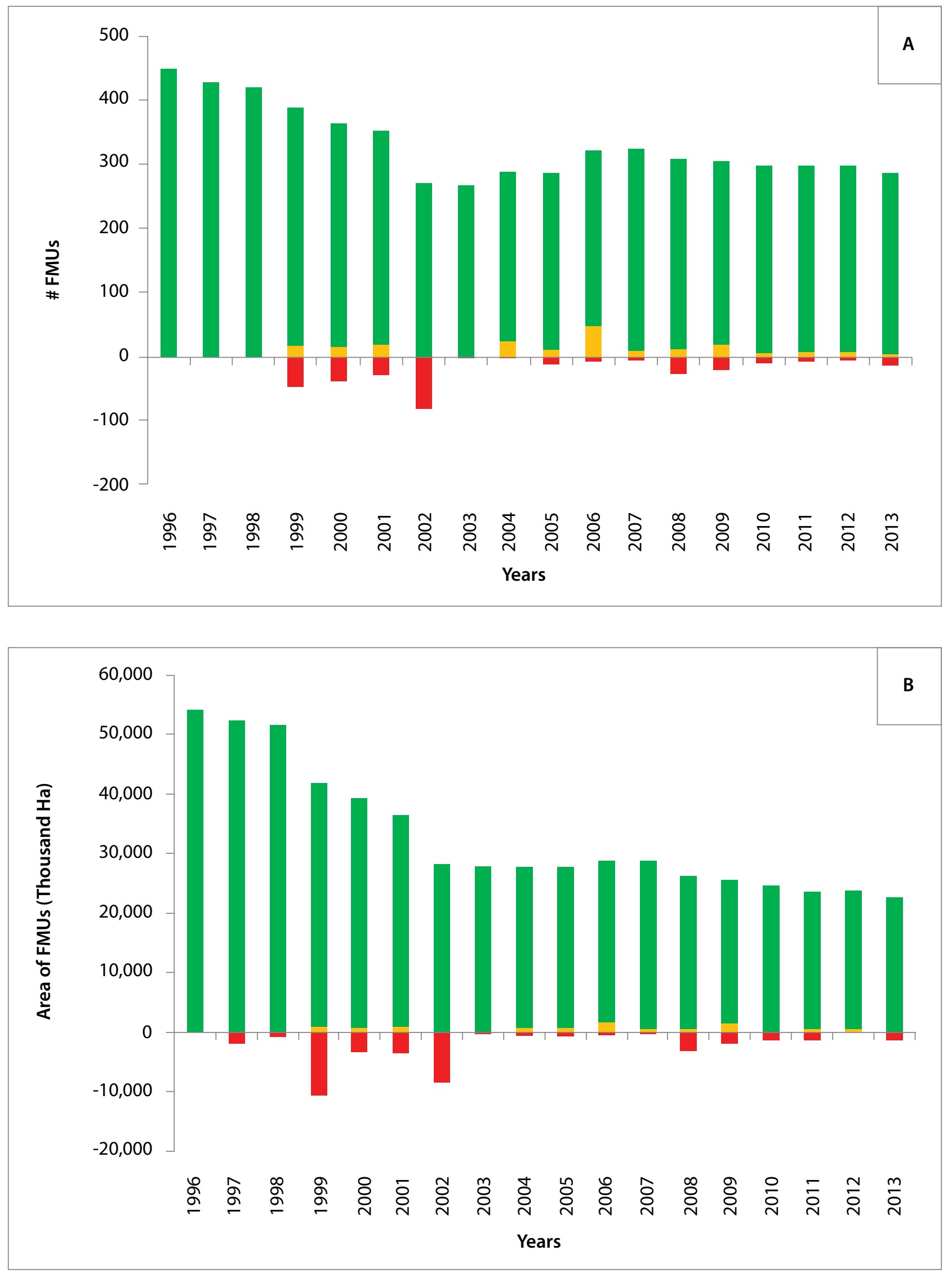

Figure 4.3. Number of active (green), new (yellow), and expired (red) FMUs operating in natural forests in Indonesia (A), and area occupied by each level of activity (B). 

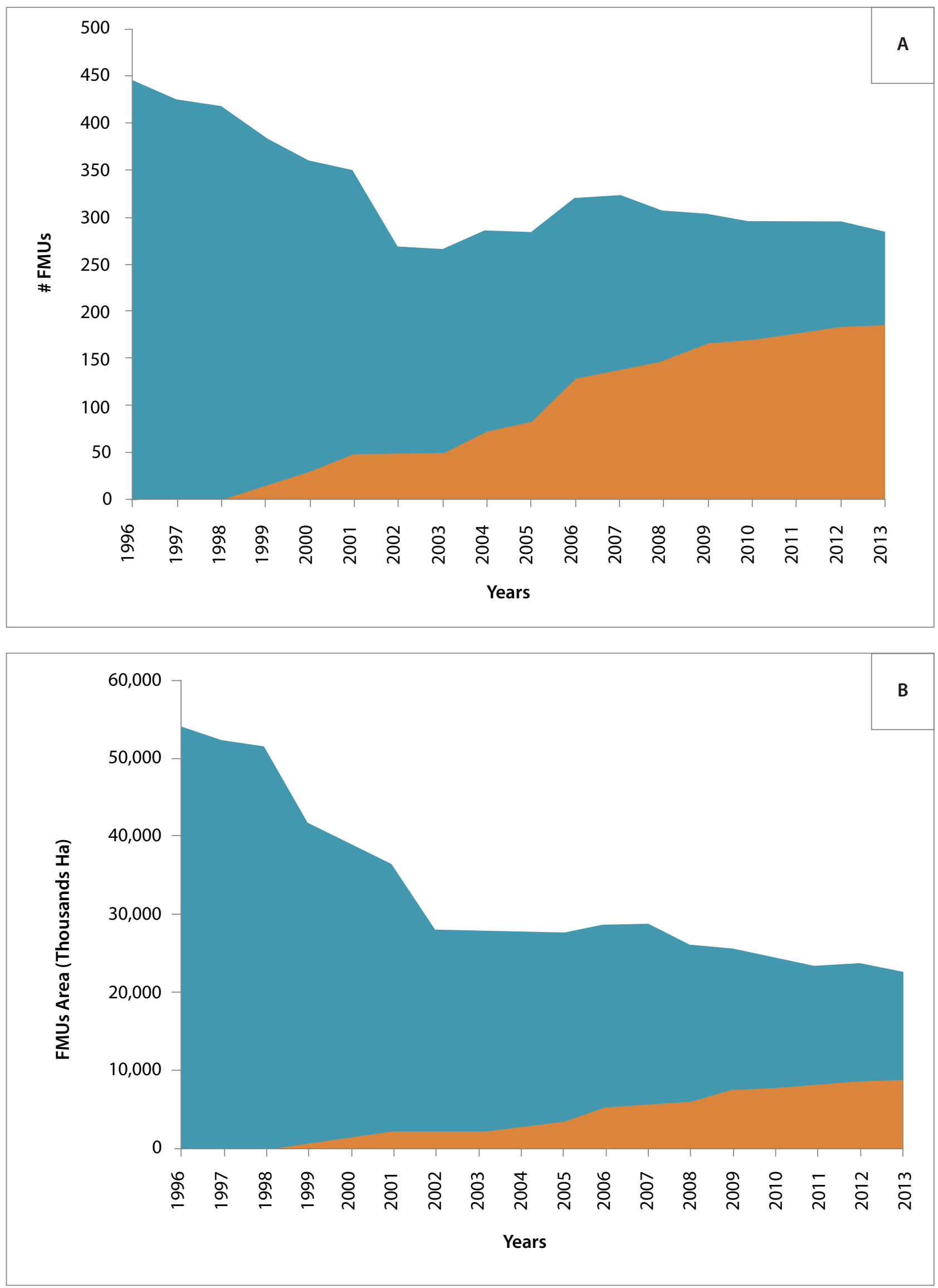

Figure 4.4. Cumulative number of newly created FMUs as a proportion of the total number of FMUs. (blue = all active FMUs; brown = cumulative new FMUs) [A]; and cumulative area these FMUs as a proportion of the total area of FMUs in natural forest in Indonesia (blue = all active FMUs; brown = cumulative new FMUs) [B]. 
Although the proportion of new FMUs steadily increased over the observation period, none of the 15 successfully certified were new. We believe this indicates that the older and more established FMUs have better long-term business strategies and thus more concerns about sustainability, better infrastructure, and more skilled in implementing improved forest management techniques, all of which would make it easier for them to become certified.

\subsubsection{General dynamics of FMUs engaged in certification}

As of late 2013 there were 14 FSC certified FMUs in Indonesia (Appendix II). The proportion engaged in certification was relatively low but increased over the study period, especially after 2007 (Figure 4.5). This increment was the result of two simultaneous processes: real increases in the number of FMUs engaged in certification, and the decrease in the total number of FMUs.

Overall, 70 FMUs (21\%) considered certification at some point between 1996 and 2013. A closer look at the FMUs active in FSC certification (i.e., considering or making transitions to more advanced stages along the continuum) shows that uptake of certification varied markedly over time. Yet, the pattern of FMUs considering certification was similar to the population dynamics of FMUs, particularly for newly created FMUs, whereas there was decreased uptake during the period of $2000-2005$ (Figure 4.6A). It should be noted that by definition, all FMUs that considered certification during the early period of study were pooled in 1996 (see Methods) so there were few other FMUs that considered certification over several years after that time.

Of all FMUs that took a step towards certification, 20 abandoned the intention to pursue it, particularly during the later portion of the observation period (Figure 4.6B). The remaining 50 either stayed in considering certification or moved to more advance stages along the continuum. Of the 50 FMUs that engaged in some way in certification, 39 moved to en route to certification and 11 remained in considering certification. It was also noticed that of those FMUs that engaged in certification (i.e., FSC-active FMUs), only 20 FMUs (29\%) were new FMUs created in 1999 or thereafter. FMUs that abandoned the intention to pursue certification are equally distributed between new and old FMUs.

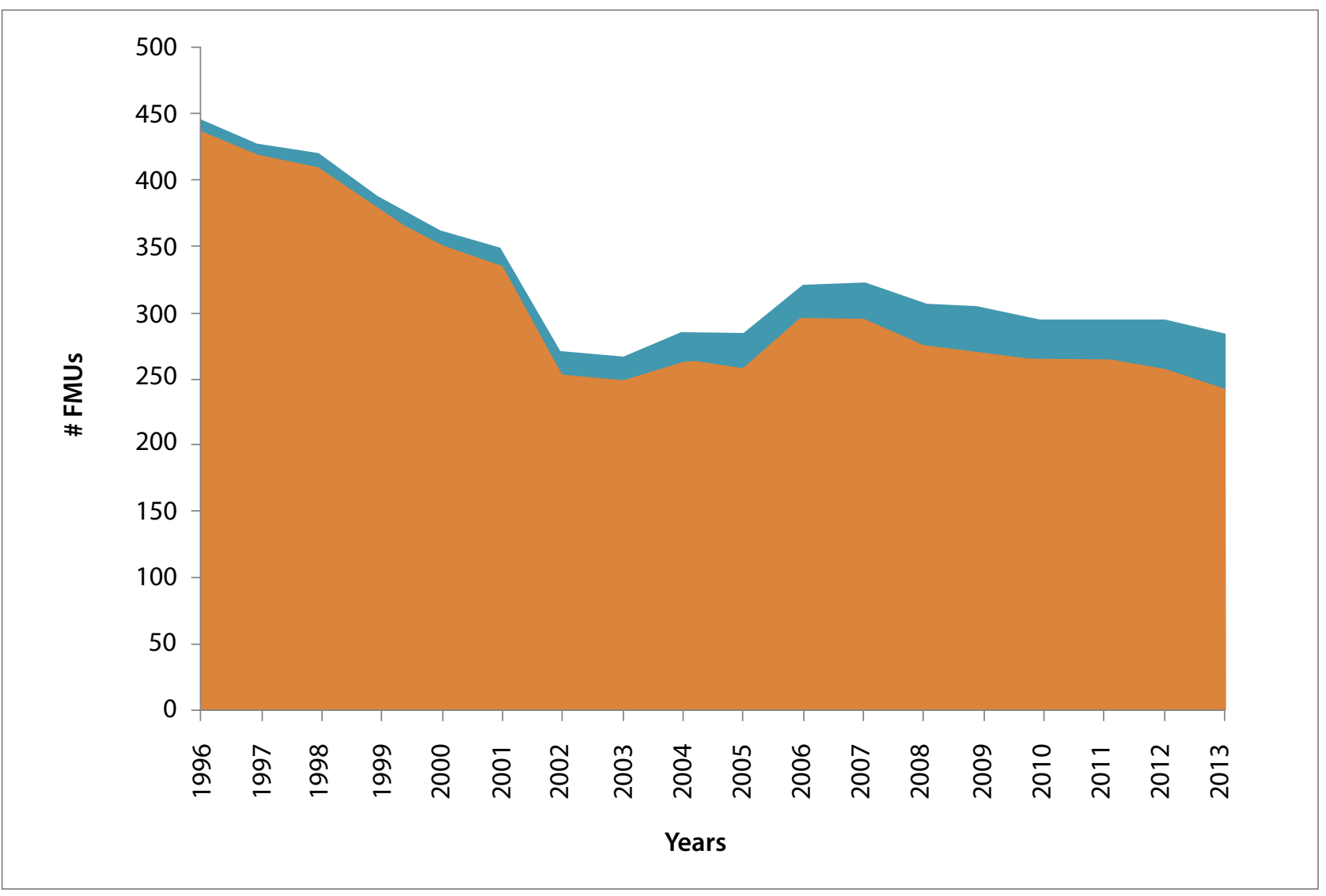

Figure 4.5. Proportion of active operating FMUs that engaged in FSC certification (blue) of natural forest management in Indonesia (1996-2013) and that of FMUs never becoming involved with FSC certification (brown). 

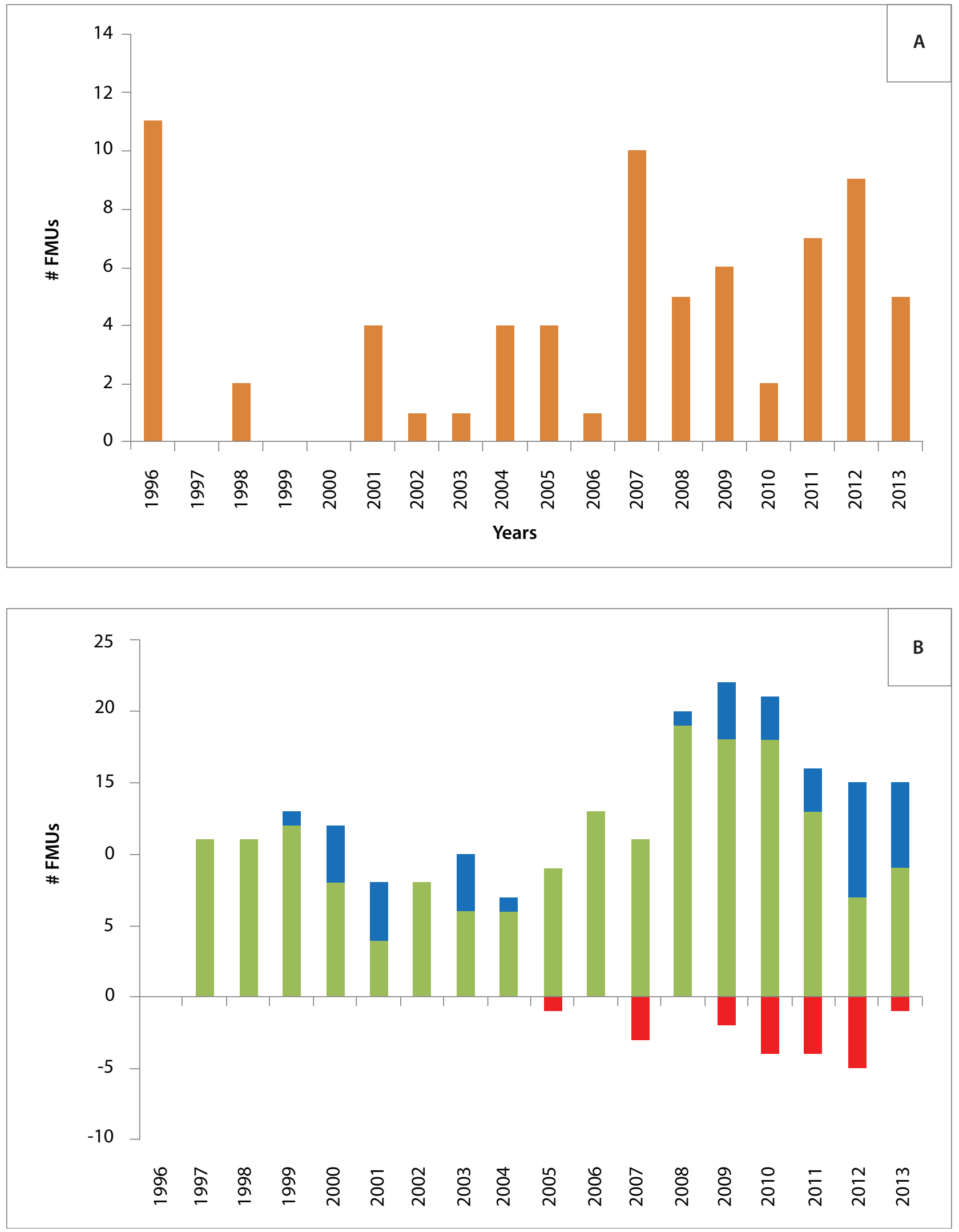

Figure 4.6. Number of natural forest FMUs in Indonesia in the considering certification stage $[A]$; and that made three different decisions once in that stage. FMUs either stayed in considering certification (D4: green), advanced to en route to certification (D5; blue), or moved back to never certified [D3; red) [B]. Note scale difference between panels. 
Over the 18-year study period, the null hypotheses of no difference among probabilities of taking the next step along the certification continuum (i.e., en route to certification) was found in 12 situations during 9 years for all the key linkages on the certification continuum (Appendix III). Over the remaining years, except for 1999 and 2001, FMUs consistently made the same decision (i.e., to remain in considering certification, en route to certification, or certified). Significant differences in the proportion of FMUs making decisions were found in 9 years for FMUs that decided to remain in considering certification, and in 3 years to remain en route to certification. FMUs seemed particularly reluctant to advance further along the continuum during 2002.

Regarding the fate of FMUs that made the decision to consider certification, it took them at least three years to enter the formal process of certification (i.e., entering en route to certification) during the early study period, but then this time became shorter (Figs. 4.6A and B). Reportedly, better information about certification and financial support received by FMUs encouraged them to make certification decisions more quickly. Additionally, certification coaches helped FMUs to progress more rapidly towards certification (Ruslandi et al. 2014).

\subsubsection{A detailed look at the dynamics of FMUs advancing into certification}

\section{The first step: abandoning The Never Certified stage}

Results of the LRT showed a significant low uptake of certification by FMUs for all years. Annual frequencies of FMUs staying in the never certified stage were higher when compared to those of FMUs that considered certification or that ceased to exist. The probabilities of these three linked decisions (i.e., decisions D1, D2, and D16 in Figure 4.2; Table 4.2) were significantly different from equal for all years $(\mathrm{P}<0.001$; Table 4.3). In some years, no FMUs made decision D2 to consider certification.

\section{Next step: once FMUs are in Considering Certification}

After an FMU considers certification (i.e., taken decision D2), the next step is to begin the formal process of becoming certified by getting involved in training to improve forest management practices (i.e., via TFT or other supporting program), or undergoing a series of assessments and audits (i.e., pre- and main- assessment). The goal of these steps is to determine the extent to which the FMU is managed according to FSC standards and what corrective measures are needed to qualify for certification. At that point the FMU can take either one of three decisions: to remain in the considering certification (D4) stage, to advance towards en route to certification (D5), or to lose interest and revert back to never certified (D3). Most reversions of FMUs to the never certified occurred after 2005 (all years with the exception of 2006 and 2008).

Three distinct time periods of 1999-2001, 2003-2004, and after 2007 can be discerned (Figure 4.6B). FMUs that were en route to certification during 1996-2001 benefitted from donor-funded projects or the APHI certification program. Those that entered this stage during 2003-2004 were influenced by forest-market linking programs supported by TFT, TFF, TNC and WWF. After 2008, the transition to en route to certification seemed to be much influenced by financial support from TBI.

Many FMUs abandoned the intention to pursue certification during the later years of the study. This situation can be partly explained by the fact that recently, many FMUs were drawn to certification by potential short-term market benefits through forest-market linking programs and/or pressure from buyers. The programs required FMUs to join the certification assistance program. Many of these FMUs did not have sufficient resources to get certified and were only interested in the program to access a short benefit offered by the forest-market linking program (i.e., improved market access and some price premiums). In many cases, the FMUs did not have their own forest industry and the decision to join the program was dictated by their main log buyers or logging contractors. When market benefits ceased, these FMUs quit the program (pers. obs.).

There are three linked decisions for an FMU already in the en route to certification stage; it can become certified (D10), fail to do so (D7), or stay in that stage (D6; Figure 4.2). Over the 19962013 study period, 39 FMUs transitioned into en route to certification (Figure 4.7A) of which 15 became certified (D10), 10 failed to become certified (D7), and the remaining stayed in en route to certification (D6). During 4 years (2000, 2002, 2003, and 2010) there were no changes in certification status (Table 4.4; Figure 4.7B). 
Table 4.2. Results of likelihood ratio test for linked annual certification decisions that moved FMUs engaged in natural forest management into certification for the period between 1996-2013. Brackets indicate simultaneous $95 \%$ confidence intervals. Linked decisions originate from the Never Certified stage (Figure 4.2). Bolded values correspond to probabilities with higher values. Appendix III presents results of LRT analyses for all annual transitions along the certification continuum.

\begin{tabular}{|c|c|}
\hline Year & Probabilites [95\% confidence intervals] \\
\hline 1996 & $\mathrm{P}<0.001 ; \mathbf{D} 1=0.928[0.908-0.952] ; \mathrm{D} 2=0.025[0.004-0.048] ; \mathrm{D} 16=0.047[0.027-0.070]$ \\
\hline 1997 & $\mathrm{P}<0.001 ; \mathbf{D} 1=\mathbf{0 . 9 8 3}[0.974-0.995] ; \mathrm{D} 16=0.017[0.007-0.029]$ \\
\hline 1998 & $\mathrm{P}<0.001 ; \mathbf{D} 1=\mathbf{0 . 8 7 5}[0.846-0.907] ; \mathrm{D} 2=0.005[0-0.037] ; \mathrm{D} 16=0.120[0.090-0.151]$ \\
\hline 1999 & $\mathrm{P}<0.001 ; \mathbf{D} 1=0.896[0.869-0.927] ; \mathrm{D} 16=0.104[0.078-0.136]$ \\
\hline 2000 & $\mathrm{P}<0.001 ; \mathbf{D} 1=0.917[0.891-0.945] ; \mathrm{D} 16=0.083[0.057-0.111]$ \\
\hline 2001 & $\mathrm{P}<0.001 ; \mathrm{D} 1=0.746[0.701-0.793] ; \mathrm{D} 2=0.012[0-0.060] ; \mathrm{D} 16=0.243[0.198-0.290]$ \\
\hline 2002 & $\mathrm{P}<0.001 ; \mathbf{D} 1=0.98[0.968-0.997] ; \mathrm{D} 2=0.008[0-0.024] ; \mathrm{D} 16=0.012[0-0.028]$ \\
\hline 2003 & $P<0.001 ; \mathbf{D} 1=0.984[0.972-0.997] ; \mathrm{D} 2=0.004[0-0.017] ; \mathrm{D} 16=0.012[0-0.025]$ \\
\hline 2004 & $\mathrm{P}<0.001 ; \mathrm{D} 1=0.936[0.914-0.966] ; \mathrm{D} 2=0.015[0-0.045] ; \mathrm{D} 16=0.049[0.026-0.078]$ \\
\hline 2005 & $\mathrm{P}<0.001 ; \mathbf{D} 1=0.95[0.931-0.977] ; \mathrm{D} 2=0.015[0-0.042] ; \mathrm{D} 16=0.034[0.015-0.061]$ \\
\hline 2006 & $\mathrm{P}<0.001 ; \mathbf{D} 1=0.976[0.963-0.992] ; \mathrm{D} 2=0.003[0-0.02] ; \mathrm{D} 16=0.02[0.007-0.036]$ \\
\hline 2007 & $\mathrm{P}<0.001 ; \mathbf{D} 1=\mathbf{0 . 8 7 6}[0.843-0.912] ; \mathrm{D} 2=0.033[0-0.069] ; \mathrm{D} 16=0.09[0.057-0.126]$ \\
\hline 2008 & $P<0.001 ; \mathbf{D} 1=\mathbf{0 . 9 0 3}[0.875-0.938] ; \mathrm{D} 2=0.018[0-0.053] ; \mathrm{D} 16=0.079[0.05-0.114]$ \\
\hline 2009 & $P<0.001 ; D 1=0.938[0.915-0.966] ; D 2=0.022[0-0.051] ; D 16=0.04[0.018-0.069]$ \\
\hline 2010 & $\mathrm{P}<0.001 ; \mathbf{D} 1=\mathbf{0 . 9 6 2}[0.943-0.983] ; \mathrm{D} 2=0.008[0-0.029] ; \mathrm{D} 16=0.031[0.011-0.052]$ \\
\hline 2011 & $P<0.001 ; \mathbf{D} 1=\mathbf{0 . 9 4 7}[0.924-0.971] ; \mathrm{D} 2=0.027[0.004-0.051] ; \mathrm{D} 16=0.027[0.004-0.051]$ \\
\hline 2012 & $\mathrm{P}<0.001 ; \mathrm{D} 1=\mathbf{0 . 9 1 2}[0.881-0.943] ; \mathrm{D} 2=0.035[0.004-0.066] ; \mathrm{D} 16=0.054[0.023-0.085]$ \\
\hline
\end{tabular}

Table 4.3. Results of likelihood ratio tests for linked annual certification decisions on the certification trajectory (1996-2013). Linked decisions originate from the considering certification stage (Figure 4.2). Bolded values correspond to probabilities with higher values. Asterisks indicate statistical significance $(p<0.05)$. Brackets indicate simultaneous $95 \%$ confidence intervals.

\begin{tabular}{ll}
\hline Year & Probabilities [95\% confidence intervals] \\
\hline 1997 & $\mathrm{D} 4=1(100 \%)$ \\
1998 & $\mathrm{D} 4=1(100 \%)$ \\
$1999^{*}$ & $\mathrm{P}<0.001 ; \mathrm{D} 4=\mathbf{0 . 9 2 3}[0.846-1] ; \mathrm{D} 5=0.077[0-0.205]$ \\
2000 & $\mathrm{P}=0.244 ; \mathrm{D} 4=0.667[0.5-0.972] ; \mathrm{D} 5=0.333[0.167-0.638]$ \\
2001 & $\mathrm{P}=1.000 ; \mathrm{D} 4=0.5[0.25-0.87] ; \mathrm{D} 5=0.5[0.25-0.87]$ \\
2002 & $\mathrm{D} 4=1(100 \%)$ \\
2003 & $\mathrm{P}=0.526 ; \mathrm{D} 4=0.6[0.4-0.945] ; \mathrm{D} 5=0.4[0.2-0.745]$ \\
$2004^{*}$ & $\mathrm{P}<0.05 ; \mathrm{D4}=\mathbf{0 . 8 5 7}[0.714-1] ; \mathrm{D} 5=0.143[0-0.373]$ \\
$2005^{*}$ & $\mathrm{P}<0.01 ; \mathrm{D} 3=0.1[0-0.265] ; \mathrm{D4}=\mathbf{0 . 9}[0.8-1]$ \\
2006 & $\mathrm{D} 4=1(100 \%)$ \\
$2007^{*}$ & $\mathrm{P}<0.05 ; \mathrm{D} 3=0.214[0.071-0.442] ; \mathbf{D 4}=\mathbf{0 . 7 8 6}[0.643-1]$ \\
$2008^{*}$ & $\mathrm{P}<0.001 ; \mathrm{D4}=\mathbf{0 . 9 5}[0.9-1] ; \mathrm{D} 5=0.05[0-0.134]$ \\
$2009^{*}$ & $\mathrm{P}<0.001 ; \mathrm{D} 3=0.083[0-0.267] ; \mathbf{D 4}=\mathbf{0 . 7 5}[0.625-0.934] ; \mathrm{D} 5=0.167[0.042-0.351]$ \\
$2010^{*}$ & $\mathrm{P}<0.001 ; \mathrm{D} 3=0.16[0.04-0.354] ; \mathbf{D 4}=\mathbf{0 . 7 2}[0.6-0.914] ; \mathrm{D} 5=0.12[0-0.314]$ \\
$2011^{*}$ & $\mathrm{P}<0.05 ; \mathrm{D} 3=0.2[0.05-0.432] ; \mathbf{D 4}=\mathbf{0 . 6 5}[0.5-0.882] ; \mathrm{D} 5=0.15[0-0.382]$ \\
2012 & $\mathrm{P}=0.696 ; \mathrm{D} 3=0.25[0.05-0.49] ; \mathrm{D} 4=0.35[0.15-0.59] ; \mathrm{D} 5=0.4[0.2-0.64]$ \\
$2013^{*}$ & $\mathrm{P}<0.05 ; \mathrm{D} 3=0.062[0-0.333] ; \mathrm{D4}=\mathbf{0 . 5 6 2}[0.375-0.833] ; \mathrm{D} 5=0.375[0.188-0.645]$ \\
\hline
\end{tabular}


Table 4.4. Results of likelihood ratio tests for linked annual certification decisions leading to the certified stage (1996-2013). Linked decisions originate from the en route to certification stage (Figure 4.2). Bolded values correspond to probabilities with higher values. Asterisks indicate statistical significance $(p<0.01)$. Brackets indicate simultaneous $95 \%$ confidence intervals.

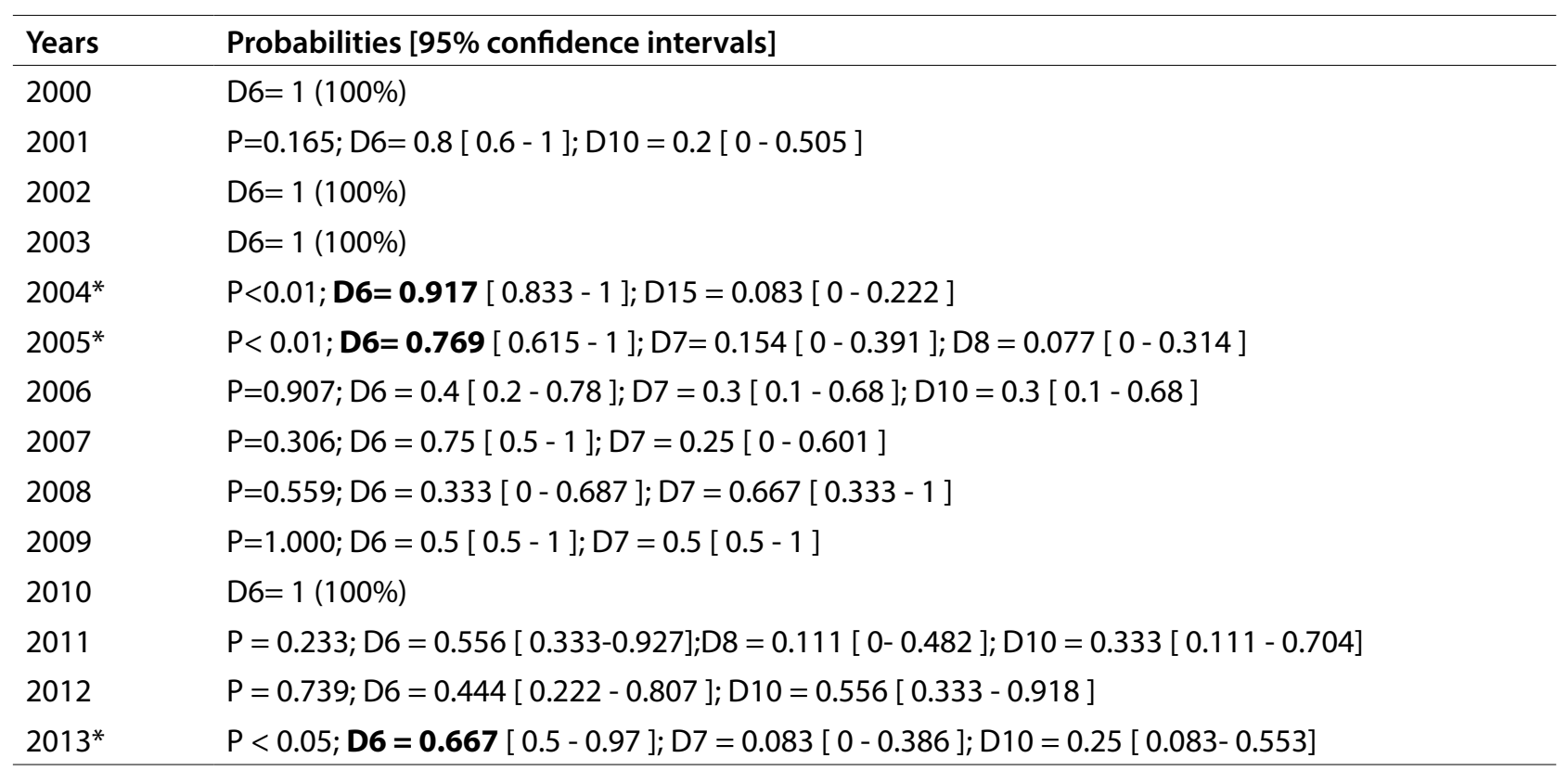

Acquiring certification either happened very early during the study period (2001, 1 FMU) and then between 2005-2006 (4 FMUs), or late (after 2010; 10 FMUs). During the 2002-2004 period, FMUs were reluctant to get certified because their attention and effort was focused on business survival due to the price-depletion effects of illegal logging. In later years (2007-2009), the global financial crisis was associated with disappearance of the market incentives for specific certified timber products. During the crisis, other FMUs slowed down their efforts to become certified and tended to be in cautious about pursuing certification.

\section{Dynamics after becoming certified}

Once certified, most FMUs remained certified. During two of the 12 years during which FMUs were certified, one FMU lost its certificate (i.e., suspended in 2004, the same year that a different FMU became certified (D15); one FMU was certified in 2004 but then had its certificate suspended in the same year, was certified again in 2006, lost its certificate again in 2011, but got it back in 2012 (D8); and, finally, another FMU certified in 2006 lost its certificate in 2011 (D12); Figure 4.8; Appendix III). In 2011 two FMUs lost their certificates out of 15 FMUs that were certified at one point in time. The one FMU that recovered its certificate had actually lost it certificate twice (2004 and 2011) and recovered it again twice (later in 2004 and 2012). Another FMU that lost its certificate in 2011 is currently reconsidering certification.
In terms of area, the 14 FMUs with valid FSC certificates ranged 41,540-216,580 ha (mean = $123,051 \mathrm{ha})$. One FMU that lost its certificate was the largest $(267,600$ ha; Figs. 4.9A and B). Of the 10 FMUs that failed to become certified, two ceased to exist, six returned to the never certified stage, and two reconsidered certification, one of which then became certified again. One of the two FMUs that reconsidered certification took this action immediately and the other one did it over a period of three years (D 8; Figure 4.2).

These decisions seem to have been motivated by availability of support from certification coaches. More specifically, one of the FMUs reportedly was motivated by the desire to supply timber to the TFT member buyers-group. The other FMU participated in TNC-run IFM training.

\subsubsection{Forest certification dynamics by certification body (CB)}

Between 1999, when the first certification audit was conducted, and 2007, the only CBs active in natural forests in Indonesia were the Société Générale de Surveillance (SGS) and RA Smartwood (RA). In 2008, Soil Association Woodmark (SA), Scientific Certification Systems (SCS), and Control Union (CU) started to operate, but RA conducted all the certification audits in natural forests except for two FMUs audited by SGS. 

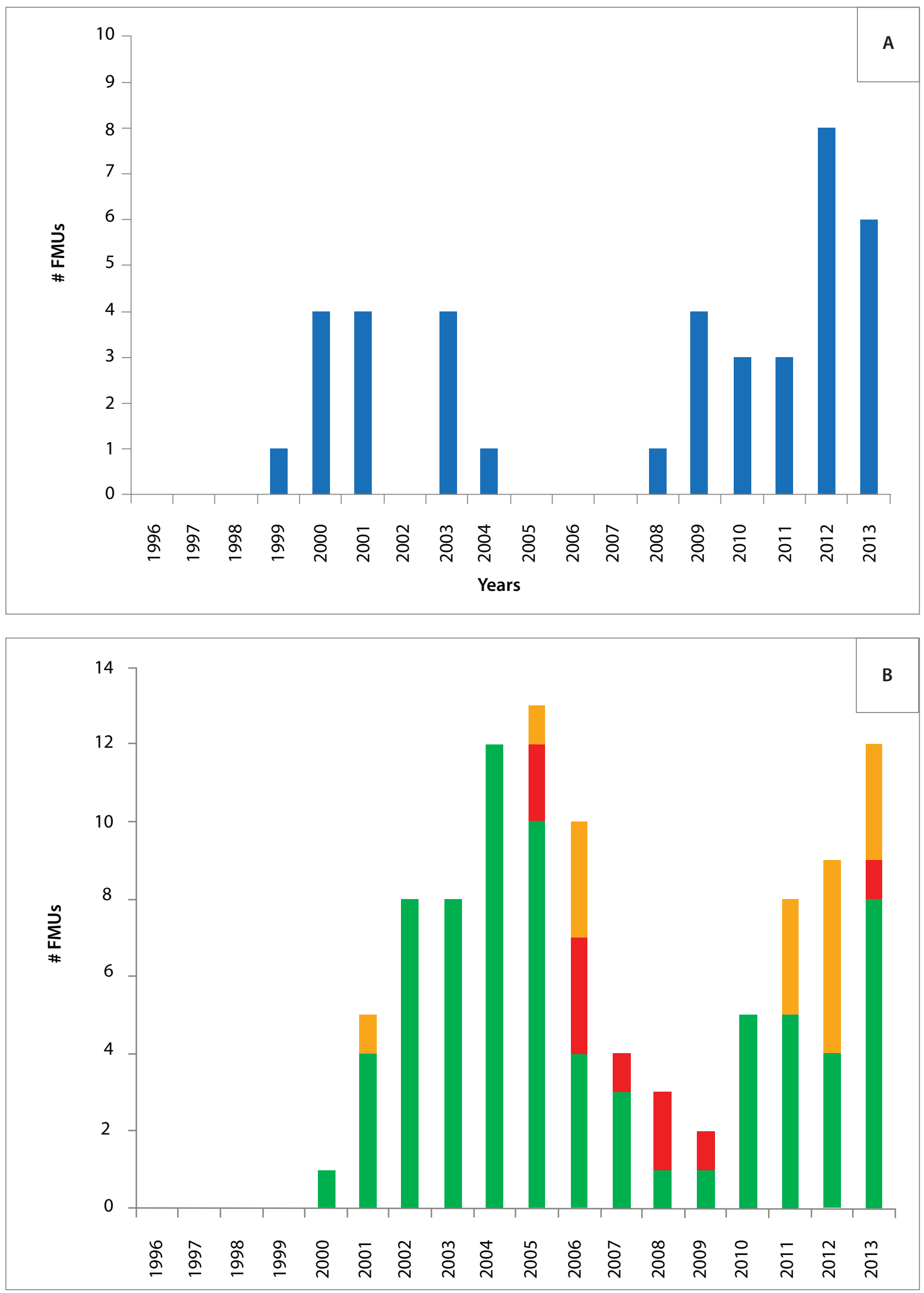

Figure 4.7. Number of FMUs in the en route to certification stage (A) and three different transitions further along the certification continuum: FMUs that remained in that stage (D6: green), that failed to become certified (D7; red), and certified (D10: yellow). 

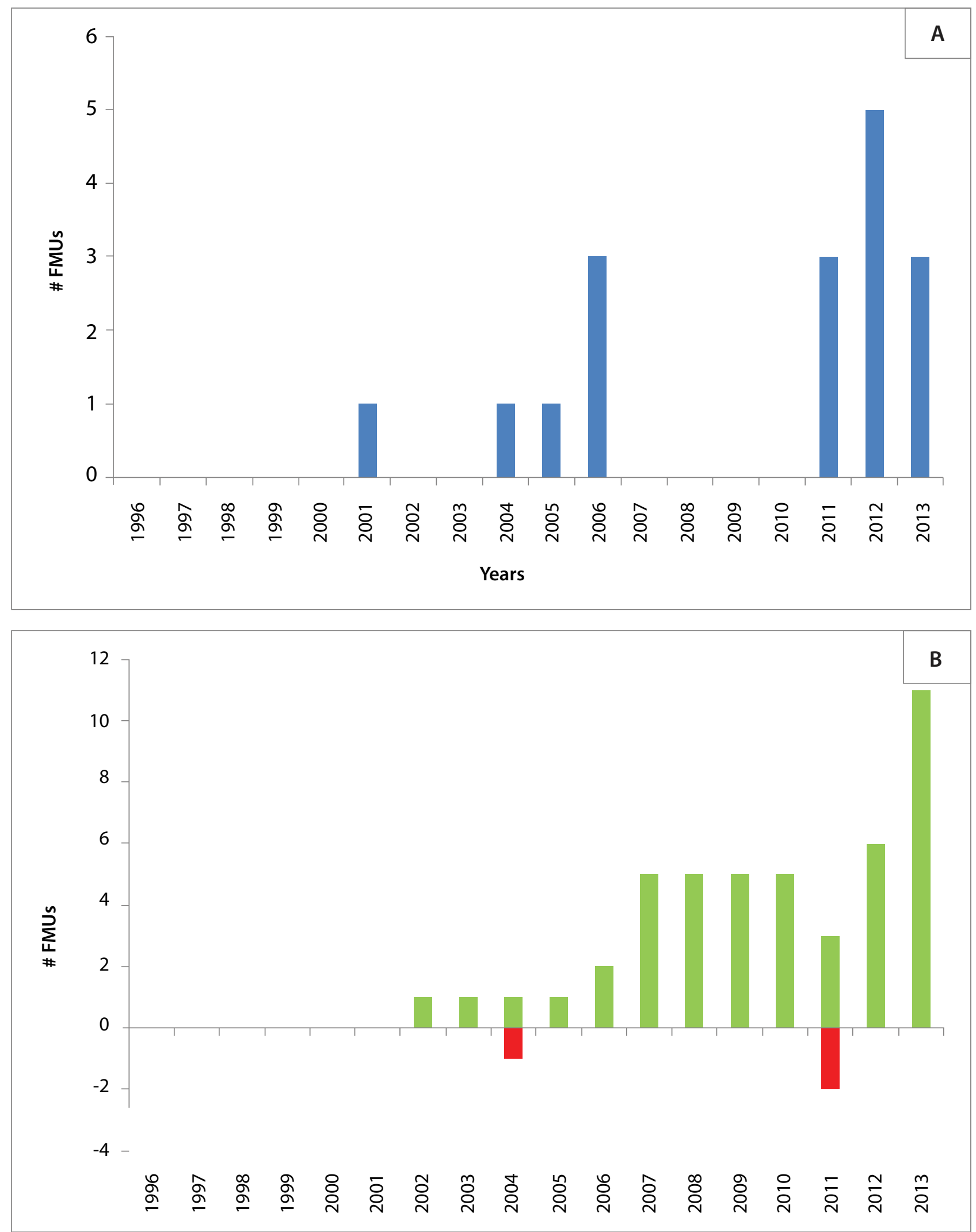

Figure 4.8. Number of newly certified FMUs [A], and two different decisions once an FMU was certified: remained certified (D11; green) or lost certificate (D12: red) [B]. 

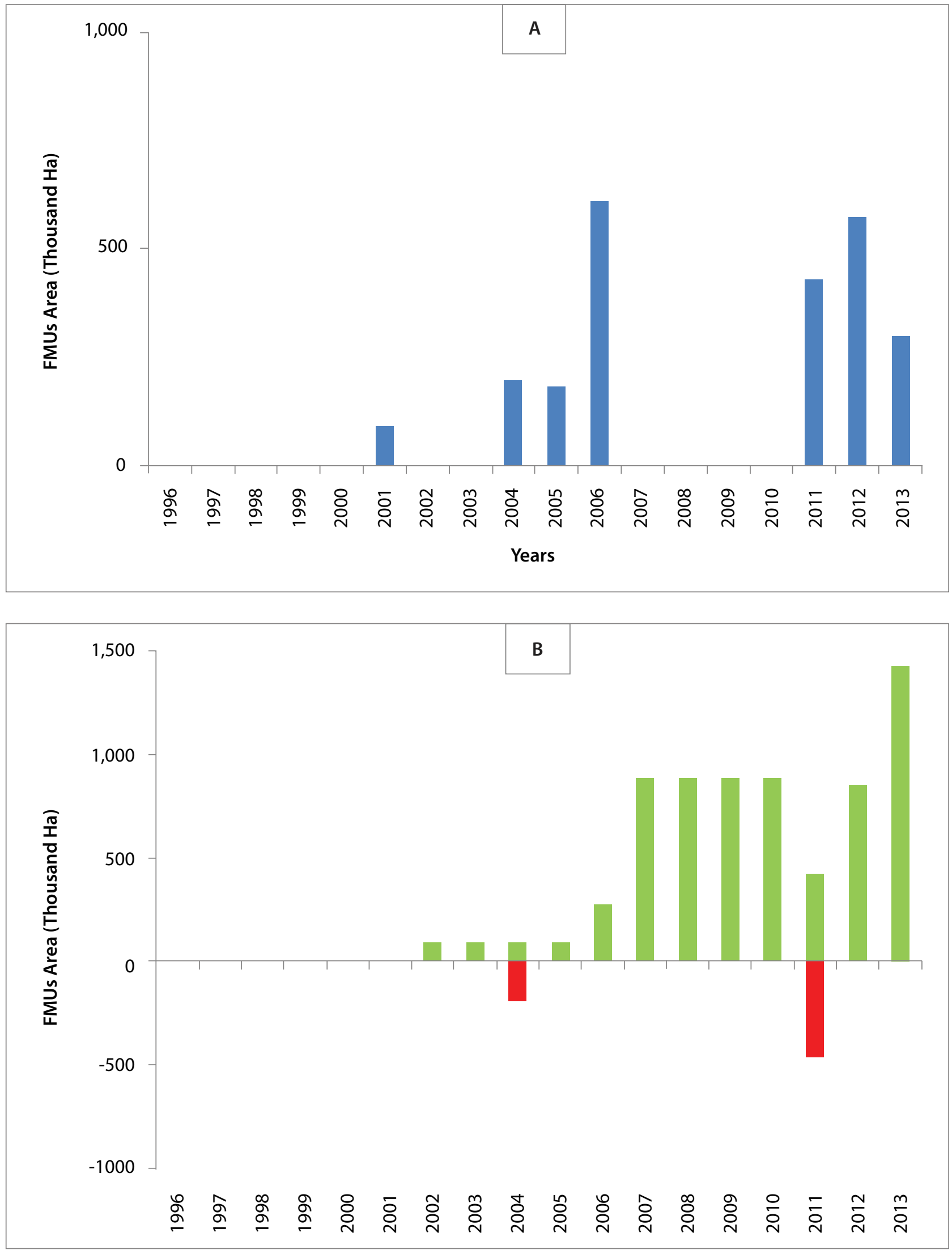

Figure 4.9. Area of newly certified FMUs $[A]$ and two different decisions once an FMU was certified: remained certified (D11; green) or lost its certificate (D12; red) [B]. 
SGS and RA were the only certification bodies operating in Indonesian natural forests during the early period. In 2003, one FMU switched CB from SGS to RA. This FMU was audited by SGS in 2001 and then audited again by RA 2003 apparently due to the suspension of SGS Indonesia by FSC and the decision of SGS to close its offices in Indonesia. This closure was probably related to FSC's restriction on SGS's issuance of forest management certificates pending a review of its auditing processes. SGS resumed FSC certification in Indonesia in 2006. As of 2010, RA certified four FMUs and SGS, one (Figure 4.10A). Since 2011, three other CBs contributed to the auditing activities but only RA was associated with one lost certificate and one failed attempt to certification (Figures $4.10 \mathrm{~B}$ and $\mathrm{C}$ ).

\subsection{Hypothesized links between certification dynamics and political and economic events and trends}

In any year, an FMU could make any decision along the certification continuum. FMU characteristics (e.g., size, technical and financial capabilities) and motivation will shape these decisions. At the same time, choices made by FMUs will be directly or indirectly influenced by factors that operate at national, regional and global scales.

Assessing the dynamics of FMU certification decisions from the perspective of external drivers revealed a low uptake of certification, if measured by the number of FMUs that made both a considering, and en route to certification decisions during period of $1996-2001$. During this period, logging operations benefitted from internationallyfunded forestry development projects (Figure 4.11; Appendix III). At the same time, weak governance in the timber sector might have precluded other FMUs to act similarly. Factors acting as background to these dynamics were the end of the Soeharto regime and subsequent decentralization, with the recognized escalation of illegal logging (Chapter 2, this volume). It is suspected that during this time period many FMUs failed to engage in certification partly due to the existence of rampant illegal logging and the lack of consolidation of the forestry business sector. When illegal timber flooded the markets, prices dropped precipitously, which led several FMUs to cease their operations. A slow pace of creation of new FMUs was also observed over that period (Figure 4.3).
During 2003-2009, forest-market linking programs initiated by TFF, TFT, TNC and WWF were the primary drivers of certification decisions (e.g., Ruslandi et al. 2014). These programs stimulated FMUs to consider certification, provided some funding for certification audits, and helped FMUs deal with corrective action requests in order to get certified. The global financial crisis in 2008 led to a reduced adoption of certification, particularly for FMUs that had undergone certification audits. There were no expected benefits to become certified on that year, but perceived market benefits received by some other FMUs during previous years attracted many FMUs to still join certification program (Canova and Hickey 2012, Sayer et al. 2012, Tabunan 2010). The crisis reduced demand for Indonesian forest products and eliminated the limited premium price previously enjoyed by some products in some markets (e.g., flooring and molding from bangkirai, Shorea leavis; Ruslandi et al. 2014). Following recovery from the economic crisis and triggered by the work of The Borneo Initiative (TBI), the number of FMUs engaged in the formal process of certification increased sharply after 2010. At the same time many FMUs that were interested and joined certification programs only with the expectation of a short-term benefit of links with the forest market linking programs ended up by abandoning the certification process altogether (Figure 4.11).

\subsection{Discussion}

Assessment of the certification dynamics of natural forests in Indonesia over the period of 1996-2013 showed the fluctuating decisions FMUs made along the certification continuum. The overall trend was one of increased engagement in FSC certification, particularly since 2010 , when both more CBs became active in the country and more funds were available to support the transition towards responsible forest management. Following an economics rationale, it is plausible that the ensuing competition among CBs would reduce certification costs, potentially mitigating one of the main barriers FMUs have in getting certified.

The alternative voluntary certification scheme operating in Indonesian natural forests, Lembaga Ekolabel Indonesia (LEI), seems no longer pertinent given its reduced recognition by international communities and markets (Muhtaman and Prasetyo 2006, Ruslandi et al. 2014). 


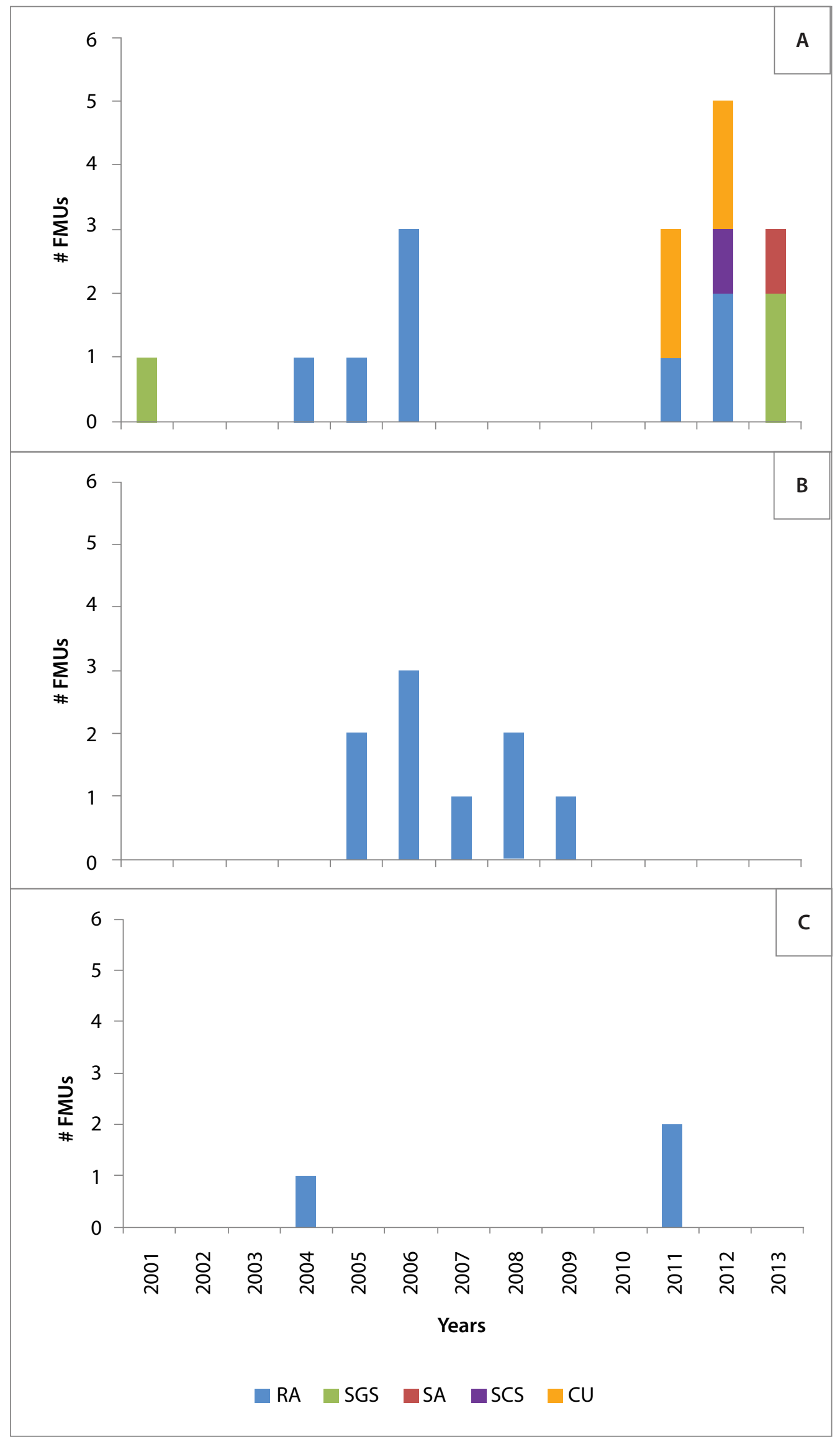

Figure 4.10. Number of certified FMUs [A]; that failed to become certified [B]; and that lost certificate [C] discriminated by certification body. 


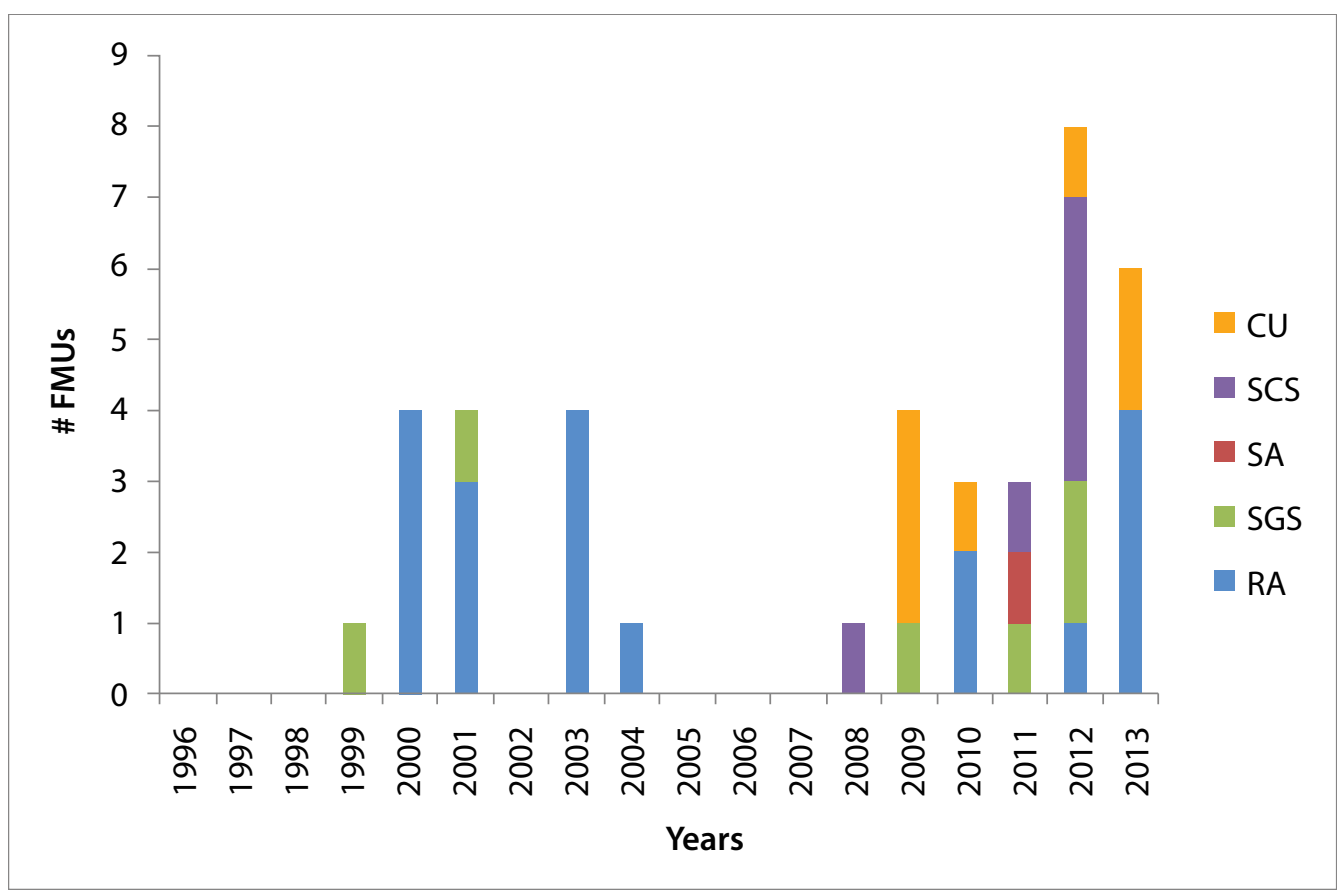

Figure 4.11. Number of FMUs operating in natural forest management that never advanced into the en route to certification stage discriminated by certification body (CB) in Indonesia.

During the initial years, the number of certified FMUs under LEI system was comparable to that of FSC due to the implementation of a joint certification protocol (JCP) between these two schemes (Muhtaman and Prasetyo 2006, Chapter 2 in this volume). After the termination of the JCP, many FMUs abandoned LEI when they were required to undergo certification reassessment. Without market incentives or other economic benefits from LEI, and emergence of the MoF's mandatory certification, it is most likely that LEI will be abandoned completely by FMUs.

The political economy of natural forest management in Indonesia is dominated by large integrated forest companies (Barr et al. 2006, Chapter 2 in this volume) that have long received high profits (e.g. Barr et al. 2006, Brown 1999, Kartodiharjo 1999). In contrast, poor timber stocks in logged-over forests and higher costs associated with decentralization (H Prayudi-APHI, pers. comm.) means that profits from logging have declined of late.

If certification is expected to expand in Indonesia, the associated costs need to be reduced or be more fully compensated by the benefits derived from market and/or incentive programs. Based on a study of five certified FMUs in Kalimantan, Ruslandi et al. (2014) estimated the average direct cost of certification as US\$D $4.76 /$ ha or US $\$ 0.1 / \mathrm{m}^{3}$. For a typical Indonesian FMU of 100,000 ha operating in natural forests, this nearly half million dollars would be hard to recover quickly through price premiums. That TBI covers half of those costs helps explain why there is little progress towards FSC certification in Indonesia. Other sources of financial support are needed (e.g., channeling funds from REDD+ and other environmental service payments) to support responsible forestry. The availability of such incentives seems timely now that most FMUs are entering previously harvested stands, yields and profits are declining, and administrative and other costs of forest management are increasing.

\subsection{Conclusions}

This study applies the concept of the certification continuum to elucidate the evolution of FSC certification of natural forest management in Indonesia. Of the FMUs operating in natural forests during 1996-2013, 20\% (70 FMUs) entered the continuum at one point in time. Of these, 39 were audited for certification and 15 became FSC certified of which only one later lost its certificate. The dynamics and probabilities along the certification continuum varied through time and seemed to be influenced more by economic than political events (Figure 4.12). 


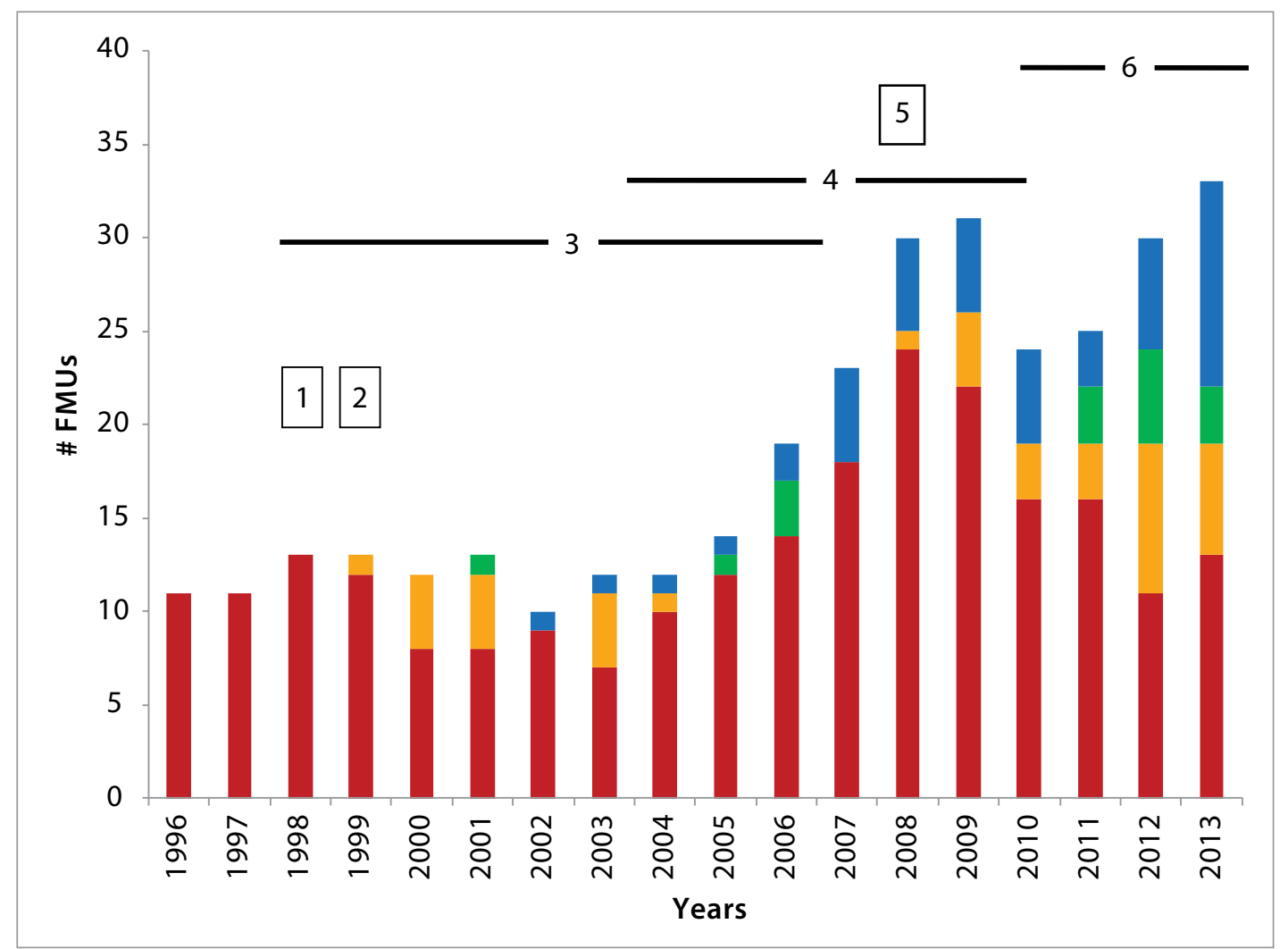

Figure 4.12. Dynamics of FMUs along the certification continuum and potential links to major political and economic events that affected the forest sector in Indonesia. Color code for decisions: considering certification (red); en route to certification (yellow); certified (green) and remain certified (blue).

Events:

1. End of the Soeharto Regime

2. Decentralization (Reformasi)

3. Rampant Illegal logging

4. Introduction of forest-market linking programs (TFF, TFT, TNC, WWF)

5. Global economic crisis

6. Support for certification from TBI

Under the current perception of forest managers, future dynamics of FSC certification in Indonesia will depend on a series of interrelated factors. First, FMUs must realize market benefits (e.g., price premiums and improved market share and access). In the meantime, both funding and technical assistance are needed to support FMUs as they become and remain certified.

Favorable governmental policies could easily promote certification in Indonesia. More specifically, if MoF's new mandatory certification requirement could be satisfied by FSC certification, a costly redundancy would be eliminated and more FMUs will move towards the more rigorous requirements of the FSC. Even if that does not happen, over the longer term, the FSC voluntary certification process could raise the bar for the mandatory scheme if auditors for the latter learn from the audit and other activities associated with the more rigorous FSC procedures. Another unlikely possibility is that MoF certification (PHPL and SVLK) will be widely accepted in lieu of FSC certification, which would be tragic for the FSC in Indonesia.

Despite recent increases in certification activity in Indonesia, most (80\%) FMUs in natural forests have displayed no tangible indication of having considered certification. It would useful to know why this is so, especially in light of all the attention to certification in the media. On the positive side, the certification coach institutions have proven to be effective in moving FMUs along the continuum. Support from TBI, for example, could lead to 9 million ha of Indonesia natural forest to be certified by 2016 (TBI 2014). The efficiency and effectiveness of these not-so-negligible resources will remain to be determined until FSC certification impacts are properly assessed. 


\subsection{References}

Barr C, Resosudarmo I, Dermawan A, McCarthy J, Moeliono M and Setiono B. eds. 2006 Decentralization of forest administration in Indonesia: Implications for forest sustainability, economic development and community livelihoods. Center for International Forestry Research (CIFOR), Bogor, Indonesia.

Brown D. 1999. Addicted to Rent: Corporate and Spatial Distribution of Forest Resources in Indonesia; Implications for Forest Sustainability and Government Policy. Jakarta, Indonesia: ITFMP.

Canova N and Hickey G.M. 2012. Understanding the impacts of the 2007-08 Global Financial Crisis on sustainable forest management in the Brazilian Amazon: A case study. Ecological Economics 83(11): 19-31.

[FSC] Forest Stewardship Council. 2014. Public Certificate Search. http://info.fsc. org/certificate.php\#result. Accessed on 10 June 2014.

Gellert PK. 2010 Rival transnational networks, domestic politics and Indonesian timber. Journal of Contemporary Asia 40: 539-567.

Kartodiharjo H. 1999. Economic loss of the state in managing natural forest. Unpublished paper prepared for Telapak Indonesia and Environmental Investigation Agency (EIA).

[LEI] Lembaga Ekolabel Indonesia. 2014. FMU and Manufacture LEI Certified Updated : July 2013. http://www.lei.or.id/files/FMU\%20 \&\%20Manufacture\%20certified\%20LEI_ July\%202013.pdf. Accessed 10 June 2014.

[MoF] Ministry of Forestry. 2001. Statistik Kehutanan Indonesia 2000. Badan Planologi Kehutanan. Depertemen Kehutanan. Jakarta.

[MoF] Ministry of Forestry. 2003. Statistik Kehutanan Indonesia 2002. Badan Planologi Kehutanan. Depertemen Kehutanan. Jakarta.

[MoF] Ministry of Forestry. 2006. Statistik Kehutanan Indonesia 2005. Badan Planologi Kehutanan. Depertemen Kehutanan. Jakarta.

[MoF] Ministry of Forestry. 2008. Eksekutif Data Strategis Kehutanan 2008. Badan Planologi Kehutanan. Depertemen Kehutanan. Jakarta.

[MoF] Ministry of Forestry. 2009. Data and Informasi Pemanfaatan Hutan 2009. Direktorat Jenderal Planologi Kehutanan. Depertemen Kehutanan. Jakarta.
[MoF] Ministry of Forestry. 2011. Data and Informasi Pemanfaatan Hutan Tahun 2011. Direktorat Jenderal Planologi Kehutanan. Kementerian Kehutanan. Jakarta.

[MoF] Ministry of Forestry. 2012. Data and Informasi Pemanfaatan Hutan Tahun 2012. Direktorat Jenderal Planologi Kehutanan. Kementerian Kehutanan. Jakarta.

[MoF] Ministry of Forestry. 2013. Basis Data Spasial Kehutanan Tahun 2013. Direktorat Jenderal Planologi Kehutanan. Kementerian Kehutanan. Jakarta.

Moore SE, Cubbage F and Eicheldinger C. 2012. Impacts of Forest Stewardship Council (FSC) and Sustainable Forestry Initiative (SFI) forest certification in North America. Journal of Forestry 110: 79-88.

Muhtaman DR and Prasetyo FA. 2006. Forest certification in Indonesia. In: Cashore B, Gale F, Meidinger E and Newsom D. eds. Confronting sustainability: Forest certification in developing and transitioning countries. Yale F\&ES Publication Series, Report Number 8.

Natural Capital Advisors. 2011. Responsible Asia Forestry and Trade (RAFT) Alliance Final Evaluation. http://pdf.usaid.gov/pdf_docs/ Pdacs537.pdf. Accessed on 10 June 2014.

Peña-Claros M, Blommerde $S$ and Bongers F. 2009. Assessing the progress made: an evaluation of forest management certification in the tropics. Tropical Resource Management. Papers 95, Wageningen University, the Netherlands.

R Development Core Team. 2008. R: A language and environment for statistical computing. $R$ Foundation for Statistical Computing, Vienna, Austria.

Romero C. \& Castrén T. 2013. Approaches to measuring the conservation impact of forest management certification. PROFOR, the World Bank, Washington, D.C. 42 p.

Romero C, Putz FE, Guariguata MR, Sills E and Cerutti PO. 2013. A review of current knowledge about the impacts of forest management certification and a proposed framework for its formal evaluation. CIFOR Occasional Paper, Bogor, Indonesia.

Ruslandi, Klassen A, Romero C and Putz FE. 2014. Forest Stewardship Council Certification of Natural Forest Management in Indonesia: Required Improvements, 
Costs, Incentives, and Barriers. In IUFROWFSE book "Forests under pressure: Local responses to global issues".

Sayer JA, Endamana D, Ruiz-Perez M, Boedhihartono AK, Eyebe A, Awono A and Usongo L. 2012. Global financial crisis impacts forest conservation in Cameroon. International Forestry Review. 14 (1). 90-98.

Tambunan TTH. 2010. Socio-Economic Impacts of the Global Economic Crisis: The Indonesian Story. Afro Asian Journal of Social Sciences 1: 1-19.

[TFF] Tropical Forest Foundation. 2014. List of TFF activities. (http://www.tff-indonesia. org/index.php/map-of-tff-activity/trainingactivities-68341. Accessed 10 June 2014.
[TFT] The Forest Trust. 2014. TFT Project Portfolio. http://www.tft-forests.org/projects/ portfolio.asp. Accessed 10 June 2014.

[TBI] The Borneo Initiative (TBI). 2014. TBI Partner organizations- forest enterprises. http://www.theborneoinitiative.org/partnerorganisations/forest-enterprises. Accessed 10 June 2014.

Villacorta PJ. 2014. Package 'MultinomialCI'. http://cran.r-project.org/web/packages/ MultinomialCI/MultinomialCI.pdf.

Worldwide Fund for Nature (WWF). 2014. Profil Perusahaan Anggota. http://www.wwf. or.id/program/inisiatif/gftnindonesia/profil_ perusahaan/index.cfm?uPage $=2$

Accessed on 10 June 2014. 


\section{Appendix 1. SFM Support Programs}

Internationally funded forestry development projects with likely direct and indirect impacts on the dynamics of certification decisions made by FMU managers.

IFM/SFM project

Sustainable Forest Management Project (SFMP)

Year : 1991 - 2002

Location: East Kalimantan

Cost: (multi million dollars)

Donor: GIZ -Germany

Goal: Sustainable management systems for natural production forests in East Kalimantan are supported by national forest policy and implemented by FMU managers and the local population.
Certification status of the FMU partners

PT. Limbang PT. Sarmiento Parakantja Timber Ganeca was certified under FSC scheme.

\begin{tabular}{ll} 
FMU partners & $\begin{array}{l}\text { Certification status of the FMU } \\
\text { partners }\end{array}$ \\
\hline $\begin{array}{l}\text { PT. Limbang } \\
\begin{array}{l}\text { Ganeca } \\
\text { (KLI group) }\end{array}\end{array}$ & $\begin{array}{l}\text { PT. Sarmiento Parakantja Timber } \\
\text { was certified under FSC scheme. }\end{array}$ \\
\hline
\end{tabular}

\begin{tabular}{lll}
\hline $\begin{array}{l}\text { Natural Resource Management Project (NRMP) } \\
\text { Year: } 1990-1997\end{array}$ & $\begin{array}{l}\text { PT. Sari Bumi } \\
\text { Kusuma }\end{array}$ & $\begin{array}{l}\text { Two FMUs in the group have } \\
\text { been FSC certified and two other }\end{array}$ \\
Location: Central Kalimantan & (Alas Kusuma & FMUs are currently in en route to \\
Cost: US $\$ 20^{\prime} 500,000$ & Group) & certification
\end{tabular}

Donor: USAID -USA

Objective: To strengthen selected Indonesian institutions so that they can (i) identify natural resources management policies and practices that constraint economic growth and (ii) design and implement the improved policies and practices to address these constraints.

\begin{tabular}{ll}
\hline Silvicultural Techniques for the Regeneration of logged over forests in & PT. Inhutani 1 \\
East Kalimantan (STREK) & Labanan \\
Year: 1989 - 1996 & \\
Location: East Kalimantan & \\
Cost: US \$ 2'300,000 & \\
Donor: CIRAD-France & \\
Objective: Development of Silvicultural technique for logged over & \\
forests in East Kalimantan. &
\end{tabular}

Failed to get certified at the first attempt and now the concession is in the en route to Certification stage.

\begin{tabular}{|c|c|c|}
\hline $\begin{array}{l}\text { Berau Forest Management Project (BFMP) } \\
\text { Year: } 1996-2002 \\
\text { Location: East Kalimantan } \\
\text { Cost: } € 14^{\prime} 091,000 \\
\text { Donor: EU } \\
\text { Goal: Demonstration of the technical possibility and economic } \\
\text { viability of sustainable management of tropical rain forests. }\end{array}$ & $\begin{array}{l}\text { PT. Inhutani } 1 \\
\text { Labanan }\end{array}$ & $\begin{array}{l}\text { Failed to get certified at the first } \\
\text { time and now the FMU is in the en } \\
\text { route to certification stage. }\end{array}$ \\
\hline $\begin{array}{l}\text { South and Central Kalimantan Production Forest Project (SCKPFP) } \\
\text { Year : } 1998-2004 \\
\text { Location: South and Central Kalimantan } \\
\text { Cost: } € 28^{\prime} 000,000 \text { (EU) } \\
\text { Donor: EU } \\
\text { Goal: to develop an integrated sustainable management system } \\
\text { for production forests in areas operated by private companies. }\end{array}$ & $\begin{array}{l}\text { PT. Aya Yayang } \\
\text { Indonesia } \\
\text { (Barito group) }\end{array}$ & $\begin{array}{l}\text { None of the FMUs of the Barito } \\
\text { group has been certified. } \\
\text { One of four FMUs in the Dwima } \\
\text { group has been certified and } \\
\text { another concession is in the en } \\
\text { route to certification stage. }\end{array}$ \\
\hline $\begin{array}{l}\text { The Bulungan Model Forest } \\
\text { Year : } 1997-2001\end{array}$ & $\begin{array}{l}\text { PT. Inhutani II } \\
\text { Malinau }\end{array}$ & $\begin{array}{l}\text { The concession is in the en route to } \\
\text { certification stage. }\end{array}$ \\
\hline
\end{tabular}

Location: East Kalimantan

Cost: ITTO US\$1;096,391

CIFOR US\$144,000

Donor: CIFOR/ITTO

Objective: (1) assessment of the effects of Reduced-Impact Logging (RIL) on biodiversity, conservation, ecological and socioeconomic aspects and (2) assessment of rural development trends and future policy options including the effects of macro-level development activities on people dependent on the forest 


\section{Appendix 2. Certified FMUs}

FSC certified natural forest operations in Indonesia.

\begin{tabular}{lcc}
\hline FMU -Company Name & Area (ha) & Date Certified \\
\hline PT Diamond Raya Timber & 90956 & $3 / 27 / 2001$ \\
PT Erna Djuliawati & 184206 & $6 / 9 / 2005$ \\
PT Intracawood Manufacturing & 195110 & $6 / 4 / 2006$ \\
PT Sari Bumi Kusuma & 147600 & $9 / 26 / 2007$ \\
PT Suka Jaya Makmur & 171340 & $9 / 30 / 2010$ \\
PT Sarmiento Parakantja Timber & 216580 & $12 / 20 / 2011$ \\
PT Narkata Rimba & 41540 & $8 / 16 / 2011$ \\
PT Belayan River Timber & 97500 & $12 / 22 / 2011$ \\
PT Roda Mas Timber Kalimantan & 69620 & $4 / 29 / 2012$ \\
PT Kemakmuran Berkah Timber & 82810 & $5 / 22 / 2012$ \\
PT Dwimajaya Utama & 127300 & $7 / 12 / 2012$ \\
PT Ratah Timber & 97216 & $03 / 15 / 2013$ \\
PT Indexim Utama & 52480 & $11 / 6 / 2013$ \\
PT Gema Hutani Lestari & 148450 & $11 / 19 / 2013$ \\
\hline
\end{tabular}

\section{Appendix 3. Results of LRT}

Full results of likelihood ratio test for linked certification annual decisions made by FMUs engaged in natural forest management in Indonesia over a study period between1996-2013. Linked decisions originate from the same stage. Yellow boxes indicate cases when only one decision of all possible that could be made was taken. Dark grey-shaded boxes indicate cases when the observed frequencies of transition cannot be distinguished from the null model of equal probability among those decisions. Light-grey shaded boxes are cases when only one of the possible decisions was made. White cells indicate statistical significance and its level is specified in each case.

\begin{tabular}{|c|c|c|c|c|}
\hline \multirow[b]{2}{*}{ Years } & \multicolumn{4}{|c|}{ Linked Certification Decisions } \\
\hline & D1, D2, D16 & D3, D4, D5 & D6, D7, D8, D10 & D11, D12, D15 \\
\hline 1996 & $\begin{array}{l}\mathrm{P}<0.001 ; \\
\mathrm{D} 1=0.928[0.908-0.952] ; \\
\mathrm{D} 2=0.025[0.004-0.048] \\
\mathrm{D} 16=0.047[0.027-0.070]\end{array}$ & & & \\
\hline 1997 & $\begin{array}{l}P<0.001 \\
D 1=0.983[0.974-0.995] ; \\
D 16=0.017[0.007-0.029]\end{array}$ & $\mathrm{D} 4=1(100 \%)$ & & \\
\hline 1998 & $\begin{array}{l}\mathrm{P}<0.001 ; \\
\mathrm{D} 1=0.875[0.846-0.907] \\
\mathrm{D} 2=0.005[0-0.037] \\
\mathrm{D} 16=0.120[0.090-0.151]\end{array}$ & $\mathrm{D} 4=1(100 \%)$ & & \\
\hline 1999 & $\begin{array}{l}\mathrm{P}<0.001 ; \\
\mathrm{D} 1=0.896[0.869-0.927] \\
\mathrm{D} 16=0.104[0.078-0.136]\end{array}$ & $\begin{array}{l}P<0.001 ; \\
D 4=0.923[0.846-1] \\
D 5=0.077[0-0.205]\end{array}$ & & \\
\hline 2000 & $\begin{array}{l}P<0.001 ; \\
D 1=0.917[0.891-0.945] ; \\
D 16=0.083[0.057-0.111]\end{array}$ & $\begin{array}{l}P=0.244 ; \\
D 4=0.667[0.5-0.972] ; \\
D 5=0.333[0.167-0.638]\end{array}$ & D6= $1(100 \%)$ & \\
\hline
\end{tabular}


Appendix 3. Continued

\begin{tabular}{|c|c|c|c|c|}
\hline \multirow[b]{2}{*}{ Years } & \multicolumn{4}{|c|}{ Linked Certification Decisions } \\
\hline & D1, D2, D16 & D3, D4, D5 & D6, D7, D8, D10 & D11, D12, D15 \\
\hline 2001 & $\begin{array}{l}P<0.001 \\
D 1=0.746[0.701-0.793] \\
D 2=0.012[0-0.060] \\
D 16=0.243[0.198-0.290]\end{array}$ & $\begin{array}{l}P=1.000 \\
D 4=0.5[0.25-0.87] \\
D 5=0.5[0.25-0.87]\end{array}$ & $\begin{array}{l}P=0.165 \\
D 6=0.8[0.6-1] \\
D 10=0.2[0-0.505]\end{array}$ & \\
\hline 2002 & $\begin{array}{l}\mathrm{P}<0.001 ; \\
\mathrm{D} 1=0.98[0.968-0.997] \\
\mathrm{D} 2=0.008[0-0.024] \\
\mathrm{D} 16=0.012[0-0.028]\end{array}$ & $\mathrm{D} 4=1(100 \%)$ & $\mathrm{D} 6=1(100 \%)$ & $\mathrm{D} 11=1(100 \%)$ \\
\hline 2003 & $\begin{array}{l}\mathrm{P}<0.001 ; \\
\mathrm{D} 1=0.984[0.972-0.997] \\
\mathrm{D} 2=0.004[0-0.017] \\
\mathrm{D} 16=0.012[0-0.025]\end{array}$ & $\begin{array}{l}P=0.526 \\
D 4=0.6[0.4-0.945] \\
D 5=0.4[0.2-0.745]\end{array}$ & $\mathrm{D} 6=1(100 \%)$ & D11= $1(100 \%)$ \\
\hline 2004 & $\begin{array}{l}\mathrm{P}<0.001 ; \\
\mathrm{D} 1=0.936[0.914-0.966] ; \\
\mathrm{D} 2=0.015[0-0.045] ; \\
\mathrm{D} 16=0.049[0.026-0.078]\end{array}$ & $\begin{array}{l}P<0.05 \\
D 4=0.857[0.714-1] \\
D 5=0.143[0-0.373]\end{array}$ & $\mathrm{D} 6=1(100 \%)$ & $\begin{array}{l}P=1.000 \\
D 11=0.5[0.5-1] \\
D 15=0.5[0.5-1]\end{array}$ \\
\hline 2005 & $\begin{array}{l}\mathrm{P}<0.001 \\
\mathrm{D} 1=0.95[0.931-0.977] \\
\mathrm{D} 2=0.015[0-0.042] \\
\mathrm{D} 16=0.034[0.015-0.061]\end{array}$ & $\begin{array}{l}\mathrm{P}<0.01 \\
\mathrm{D} 3=0.1[0-0.265] \\
\mathrm{D} 4=0.9[0.8-1]\end{array}$ & $\begin{array}{l}P<0.01 ; \\
D 6=0.769[0.615-1] ; \\
D 7=0.154[0-0.391] \\
D 8=0.077[0-0.314]\end{array}$ & $\mathrm{D} 11=1(100 \%)$ \\
\hline 2006 & $\begin{array}{l}\mathrm{P}<0.001 \\
\mathrm{D} 1=0.976[0.963-0.992] \\
\mathrm{D} 2=0.003[0-0.02] \\
\mathrm{D} 16=0.02[0.007-0.036]\end{array}$ & $\mathrm{D} 4=1(100 \%)$ & $\begin{array}{l}P=0.907 \\
D 6=0.4[0.2-0.78] \\
D 7=0.3[0.1-0.68] \\
D 10=0.3[0.1-0.68]\end{array}$ & $\mathrm{D} 11=1(100 \%)$ \\
\hline 2007 & $\begin{array}{l}\mathrm{P}<0.001 ; \\
\mathrm{D} 1=0.876[0.843-0.912] \\
\mathrm{D} 2=0.033[0-0.069] \\
\mathrm{D} 16=0.09[0.057-0.126]\end{array}$ & $\begin{array}{l}\mathrm{P}<0.05 \\
\mathrm{D} 3=0.214[0.071-0.442] \\
\mathrm{D} 4=0.786[0.643-1]\end{array}$ & $\begin{array}{l}P=0.306 \\
D 6=0.75[0.5-1] \\
D 7=0.25[0-0.601]\end{array}$ & $\mathrm{D} 11=1(100 \%)$ \\
\hline 2008 & $\begin{array}{l}P<0.001 ; \\
D 1=0.903[0.875-0.938] \\
D 2=0.018[0-0.053] ; \\
D 16=0.079[0.05-0.114]\end{array}$ & $\begin{array}{l}P<0.001 \\
D 4=0.95[0.9-1] \\
D 5=0.05[0-0.134]\end{array}$ & $\begin{array}{l}P=0.559 \\
D 6=0.333[0-0.687] \\
D 7=0.667[0.333-1]\end{array}$ & D11= $1(100 \%)$ \\
\hline 2009 & $\begin{array}{l}\mathrm{P}<0.001 \\
\mathrm{D} 1=0.938[0.915-0.966] \\
\mathrm{D} 2=0.022[0-0.051] \\
\mathrm{D} 16=0.04[0.018-0.069]\end{array}$ & $\begin{array}{l}\mathrm{P}<0.001 \\
\mathrm{D} 3=0.083[0-0.267] \\
\mathrm{D} 4=0.75[0.625-0.934] \\
\mathrm{D} 5=0.167[0.042-0.351]\end{array}$ & $\begin{array}{l}P=1.000 \\
D 6=0.5[0.5-1] \\
D 7=0.5[0.5-1]\end{array}$ & $\mathrm{D} 11=1(100 \%)$ \\
\hline 2010 & $\begin{array}{l}P<0.001 \\
D 1=0.962[0.943-0.983] \\
D 2=0.008[0-0.029] \\
D 16=0.031[0.011-0.052]\end{array}$ & $\begin{array}{l}P<0.001 ; \\
D 3=0.16[0.04-0.354] ; \\
D 4=0.72[0.6-0.914] \\
D 5=0.12[0-0.314]\end{array}$ & $\mathrm{D} 6=1(100 \%)$ & $\mathrm{D} 11=1(100 \%)$ \\
\hline 2011 & $\begin{array}{l}\mathrm{P}<0.001 \\
\mathrm{D} 1=0.947[0.924-0.971] \\
\mathrm{D} 2=0.027[0.004-0.051] \\
\mathrm{D} 16=0.027[0.004-0.051]\end{array}$ & $\begin{array}{l}\mathrm{P}<0.05 \\
\mathrm{D} 3=0.2[0.05-0.432] \\
\mathrm{D} 4=0.65[0.5-0.882] \\
\mathrm{D} 5=0.15[0-0.382]\end{array}$ & $\begin{array}{l}P=0.233 \\
D 6=0.556[0.333-0.927] \\
D 8=0.111[0-0.482] \\
D 10=0.333[0.111-0.704]\end{array}$ & $\begin{array}{l}P=0.306 \\
D 11=0.75[0.5-1] ; \\
D 12=0.25[0-0.601]\end{array}$ \\
\hline 2012 & $\begin{array}{l}\mathrm{P}<0.001 \\
\mathrm{D} 1=0.912[0.881-0.943] \\
\mathrm{D} 2=0.035[0.004-0.066] \\
\mathrm{D} 16=0.054[0.023-0.085]\end{array}$ & $\begin{array}{l}P=0.696 \\
D 3=0.25[0.05-0.49] \\
D 4=0.35[0.15-0.59] \\
D 5=0.4[0.2-0.64]\end{array}$ & $\begin{array}{l}P=0.739 \\
D 6=0.444[0.222-0.807] \\
D 10=0.556[0.333-0.918]\end{array}$ & $\mathrm{D} 11=1(100 \%)$ \\
\hline 2013 & $\begin{array}{l}P<0.001 ; \\
D 1=0.98[0.967-0.997] \\
D 2=0.02[0.008-0.038]\end{array}$ & $\begin{array}{l}P<0.05 \\
D 3=0.062[0-0.333] ; \\
D 4=0.562[0.375-0.833] ; \\
D 5=0.375[0.188-0.645]\end{array}$ & $\begin{array}{l}P<0.05 \\
D 6=0.667[0.5-0.97] \\
D 7=0.083[0-0.386] \\
D 10=0.25[0.083-0.553]\end{array}$ & $\mathrm{D} 11=1(100 \%)$ \\
\hline
\end{tabular}




\title{
Assessment of drivers of self- selection into natural forest management certification
}

\author{
Ruslandi
}

\subsection{Introduction}

Credible evaluations of the impacts of forest certification require rigorous methods for the establishment of comparative groups (i.e., counterfactuals; e.g., Ferraro 2009, Blackman and Rivera 2011). In the case of FSC certification of forest management, credible counterfactual analyses require the selection of uncertified (control) concessions that share pertinent characteristics with the certified (treated) units (Romero et al. 2013). This selection requires thorough understanding of potentially confounding variables that could affect the outcomes of the intervention (e.g., avoided deforestation or reduced soil erosion). Some of these variables can be observable characteristics of the FMUs of contextual factors under which these FMUs operate, but some are not directly observable. Here we step back from the choice of classificatory variables to focus on the motivation of FMU decision-makers in Indonesia to opt for certification. We focus mostly on the drivers and motivations for natural forest certification in Kalimantan.

Well before the first FMU underwent its first certification audit in Indonesia in 1999, there was interest in certification (Muhtaman and Prasetyo 2006, Ruslandi et al. 2014). Subsequently, FMUs decisions regarding FSC certification varied over time and were directly or indirectly related to national and global political and economic events (Chapters 2 and 4 in this volume). Additionally, certification decisions were presumably influenced and motivated by the perceived benefits of certification. Both market benefits such as price premiums and enhanced market access and non-economic benefits were apparently important (Araujo et al. 2009, Auld et al. 2003, Hartsfield and Ostermeier 2003, Overdevest and Rickenbach 2006, Ruslandi et al. 2014 ). Despite the perceived economic benefits, the substantial costs of certification were accompanied by only limited direct financial benefits to FMUs when they marketed their forest products (Ruslandi et al. 2014). For example, five natural forest concessions in Kalimantan spent USD \$300,000-700,000 each to get certified (Ruslandi et al. 2014), up to $20 \%$ of which represented implementation costs (Hartsfield and Ostermeier 2003). In contrast, price premiums were only $10-15 \%$ and only on specific products exported to Europe (Ruslandi et al. 2014); other researchers have reported financial benefits to FMUs even more modest (Hartsfield and Ostermeier 2003).

Studies on the drivers and motivations of forest companies to pursue for certification have been conducted in many regions (e.g., Argentina, Bolivia, Brazil, Canada, China, Mexico, Rusia and USA) for different types of forestry firms including community forests (Crow and Danks 2010, Humphries \& Kainer 2006, Humphries 2010, Ward 2013) and industrial companies (Araujo et al. 2009, Auld et al. 2003, Chen et al. 2011, Espinoza and Dockry 2014, Owari et al. 2006, Trishkin et al. 2014). Most of these studies reported that the perception of non-economic benefits represented the dominant motivations for the pursuit of certification, but were influenced heavily by local contexts (e.g., local timber market, government regulation and forest company structure, natural disasters). Studies on how local contexts might influence certification are scarce in Indonesia, particularly for natural forests (but see Ruslandi et al. 2014); the intention of this study is to fill this information gap. The goal is to explore the drivers and motivations of FSC natural forest certification in Indonesia, as revealed by interviews with stakeholders who were directly involved. Particular attention is paid to the dynamics of certification incentives over time and whether certification decisions could be related to 
observable characteristics of FMUs. The specific questions this study addressed are:

1. What were the external drivers of certification? Did they change over time?

2. What were the dominant internal motivations for FMU managers to be interested in certification and to become certified?

3. How were certification decisions made and by whom in the FMUs or parent companies? What factors drove variation in certification decisions across FMUs when they belong to the same parent company?

4. What were the perceived and expected benefits and major costs of certification?

5. What were the biggest challenges in obtaining and maintaining certification?

6. What are potential leverage points and prospects for increasing certification in the future?

\subsubsection{Natural forest management and certification in Indonesia}

Indonesian state forests cover a total area of approximately 133 million hectares and are classified as (1) Conservation, (2) Protection, and (3) Production Forests (MoF 2013). Natural forests for production (mainly timber) account for about 63 million ha ( $47 \%$ of the total forest area; in addition 13 million ha of production forests are allocated for industrial "monoculture" plantation forests). During the peak period of forestry activity in Indonesia in 1993, about 61.7 million ha of natural production forests were allocated to 580 forest concessions; since then, the total area allocated for natural forest concessions decreased (MoF 2008; MoF 2013). When this report was finalized (late 2014), 22 million ha of natural production forests were allocated to 285 natural forest concessions (MoF 2013). These natural production forests are mostly managed under a selective logging system with a minimum cutting diameter of $40 \mathrm{~cm}$ for all commercial species with a cutting cycle of 30 years; the system is called the Indonesia selective cutting and planting (Tebang Pilih Tanam Indonesia - TPTI; MoF 2009). This system differs from the system it replaced insofar as the minimum cutting diameter was reduced from $50 \mathrm{~cm}$ to be $40 \mathrm{~cm}$ and the cutting cycle was reduced from 35 years to 30 years.

Deforestation and degradation of natural forests in Indonesia is acknowledged as the major threat to natural forest management in forest concessions in Indonesia (but, see Sunderlin and Resosudarmo 1997, Gaveau et al. 2012, 2013). In contrast, natural forest management is believed to have great potential for biodiversity conservation (Edwards et al. 2014, Gaveau et al. 2014) and climate change mitigation (Griscom et al. 2014). Thus, sustainable forest management in natural forests, as promoted and endorsed by forest certification, is important for the permanence of forests and the environmental benefits they provide including biodiversity, carbon sequestration, and the maintenance of other forest functions.

Voluntary natural forest certification in Indonesia was formally initiated in 1998 when Lembaga Ekolabel Indonesia (LEI) accredited a number of certification bodies (e.g., Mutu Agung Lestari, TUV Reindland Indonesia and SUCOFINDO ) to carry out audits of forest management practices based on its standards. The process formally started in 1999 for natural forests, when the first concession was audited for FSC certification. As of December 2013, 14 forest concessions were certified under the FSC label covering an area of $1,722,708$ ha (FSC 2014). Two of these forest concessions were also certified by LEI and cover 411,690 ha (LEI 2014). In addition, one FMUs lost its FSC certificate in $2011(267,600$ ha). In total, 39 FMUs have been audited for FSC certification since 1999, including 15 that were certified at some point in time, covering an area of about 4.9 million ha. This number is only about $13.7 \%$ of the total number of FMUs operating in natural forests in the country and $21 \%$ in terms of area compared to total concessions in 2013 (285 concessions; 22,682,798 ha; MoF 2013). In addition to voluntary certification, starting in 2009, Indonesia's Ministry of Forestry started a legal timber verification program (SVLK) as well as mandatory forest certification (PHPL). Until the end of 2013, 23 FMUs $(1,658,060 \mathrm{ha})$ were legally verified and 92 FMUs $(10,475,872$ ha) received PHPL certification (Obidzinski et al. 2014).

The progress of natural forest voluntary certification in Indonesia has been modest, but interest seems to have increased recently, triggered by both the availability of organizations that play the role of "certification coaches" and financial support for the pursuit of certification (Ruslandi et al. 2014; TBI 2014). Despite this recent surge in interest, adoption of certification nation-wide remains low. Overall, it remains critical to understand the drivers and motivations of certification so as to clarify the impact of certification. 


\subsection{Methods}

To reveal the sources of motivation for pursuit of natural forest certification in Indonesia, semi-structured interviews (Appendix I) were conducted with people involved in the certification process. The 34 people interviewed represented a wide range of stakeholders including representatives of FMUs at different points along the certification continuum and their affiliated forest industries (19 respondents), certification bodies (4 respondents), certification coach institutions (6 respondents), timber associations (3 respondents), academics (1 respondent), and government officials (1 respondent). Information on the certification status (i.e., position on the certification continuum) of the 19 FMUs from which respondents were drawn is presented in Chapter 4 of this volume; the respondents represented three industrial FMU groups (12 FMUs) and 9 individual FMUs.

Sample selection was based on the list of names obtained from experts and guided mainly by the goal of maximizing the amount of information collected and the diversity of viewpoints. The interviews were conducted through formal meetings (21 samples), face-to-face informal conversations ( 5 samples), and phone calls (8 samples) during May-July 2013. FMUs with no network connections with certification institutions are somewhat unrepresented in the sample, but their opinions were obtained through representatives of the FMU association (APHI) to which they all belong.

During interviews the interviewer made no mention of the possible drivers and motivations to engage in certification so that the importance of these factors could be based on the frequency with which different motivating factors were mentioned by the interviewees. Additional information about drivers and motivations obtained from certification coach institutions is considered of high value because these organizations know about the FMUs from the technical level in the field to the strategic issues addressed at the owner/CEO level.

Answers for each question are ranked based on their frequency mentioned by respondents and also pooled based on stakeholder groups (e.g., representatives of FMUs or certification coaches). These motivations and drivers were considered in light of the year in which the FMUs first engaged in certification and the contemporaneous external political and economic events from the forest certification dynamics (Chapter 4, this volume) and political economy (Chapter 2, this volume) studies.

\subsection{Results}

Natural forest certification process in Indonesia was formally initiated in 1999 when the first FMU was audited against FSC standards, but interest in certification arose a few years earlier. To capture the temporal dynamics of forest certification drivers and motivations, we selected the respondents from FMUs engaging in certification over periods of $1996-2013$ and summarize the results of the interviews as six themes.

\subsubsection{Natural forest certification drivers}

The diverse drivers of natural forest certification in Indonesia mentioned during interviews are ranked in Figure 5.1 on the basis of the number of times they were mentioned. A driver of certification mentioned by all respondents was the existence of forest-market linking and certification support programs. The contributions of the government program on timber legality and mandatory certification (SVLK and PHPL) were also frequently recognized as a driver by representatives of government and the timber association, as well as by large number of FMU managers. Yet the majority of certification coaches and CBs were skeptical about this.

Representatives of FMUs involved in certification during its early stages in Indonesia (1996 - 2003) frequently mentioned a program which ran from 1995 to 1997 by the association of Indonesian forest concessionaires (APHI) to help prepare its member to meet the ITTO 2000 Target on SFM. LEI certification was also recognized as a certification driver by several FMU managers, certification bodies (CBs), and certification coaches. Donor-funded projects on SFM were also mentioned by FMU managers as having contributed to their certification activities. Whether FMUs opted for certification seems closely linked with their marketing strategy, especially if they are connected to Europe/USA markets directly through their own forest industry or indirectly through log buyers, as well as the FMU involvement in improved forest management (IFM) or certification assistance programs. These factors were more pronounced in the later period of certification dynamics, during which the best performing FMUs were particularly likely to be engaged in certification. 


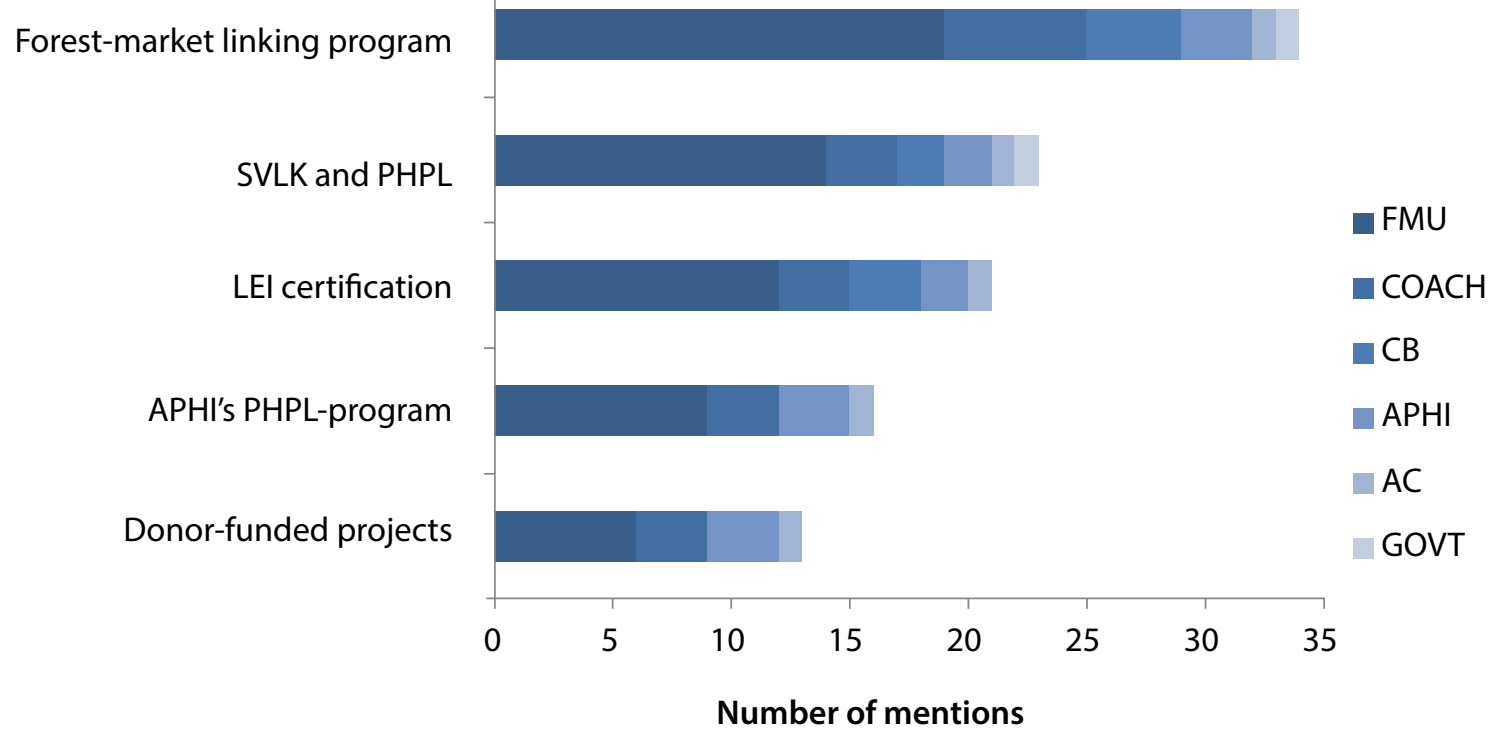

Figure 5.1. Drivers of natural forest certification mentioned by stakeholders during semi-structured interviews in Indonesia. $(n=34$; respondents often mentioned more than one driver). FMU: Forest Management Unit; $\mathrm{COACH}$ : representative of a certification/responsible forest management supporting institution; CB: certifying body; APHI: Indonesian FMU association; AC: academia; GOVT: government.

\subsubsection{Dominant motivations of FMUs for pursuit of forest certification}

FMU interests in certification varied widely and seemed to be fairly consistent over time. Shifts in interest were related to the business marketing strategy of the FMU and took into account some external drivers (e.g., market destination). For instance, during the early years of natural forest certification history in Indonesia (1999 - 2003), certification was adopted by FMUs for whom their major market was Japan, a market that did not require certification and as such, offered no market incentive for certified products. This observation clearly indicates that the dominant certification motivation during this period was not directly market driven. FMUs that engaged in certification during this period mentioned that professional improvement of staff, enhancement of company image, and potential to obtain government incentives (e.g., self-approval for the harvesting target, less monitoring visits from government officials on their operation) motivated adoption of voluntary certification. FMUs in this category typically used more advanced forest management practices at least partially due to their prior involvement in donor-funded projects or other improved forest management programs. These experienced convinced them that the capture of the benefits of certification would be relatively easy and inexpensive. One concession (PT. Diamond Raya Timber), however, might have been motivated by a market incentive for the ramin (Gonistylus bancanus $^{1}$ ) timber destined for non-Japanese markets (e.g., Europe and North America).

From 2004 to the completion of this study, interest in certification increased in Indonesia mostly due to the forest-market linking programs by a number of organizations (e.g., TFT, TFF, WWF-GFTN). Essentially, FMU interest in certification increased due to the existence of market incentives (e.g., market access and limited price premium). In particular, the decision to join certification was triggered by the desire to explore new markets for better prices since Japan and other Asian countries were overwhelmed by products from illegal sources and there was also fierce competition by cheap products from Malaysia (rubberwood) and China (poplar). The interest in certification was also strengthened by the financial and technical support from the facilitating organizations. Some FMUs that had been certified in the early years also took advantage of this market-linkage opportunity, particularly for their high quality products to green markets in Europe, North America, and Australia. For instance, some certified FMUs sell

1 This species is under Appendix 2 of CITES 


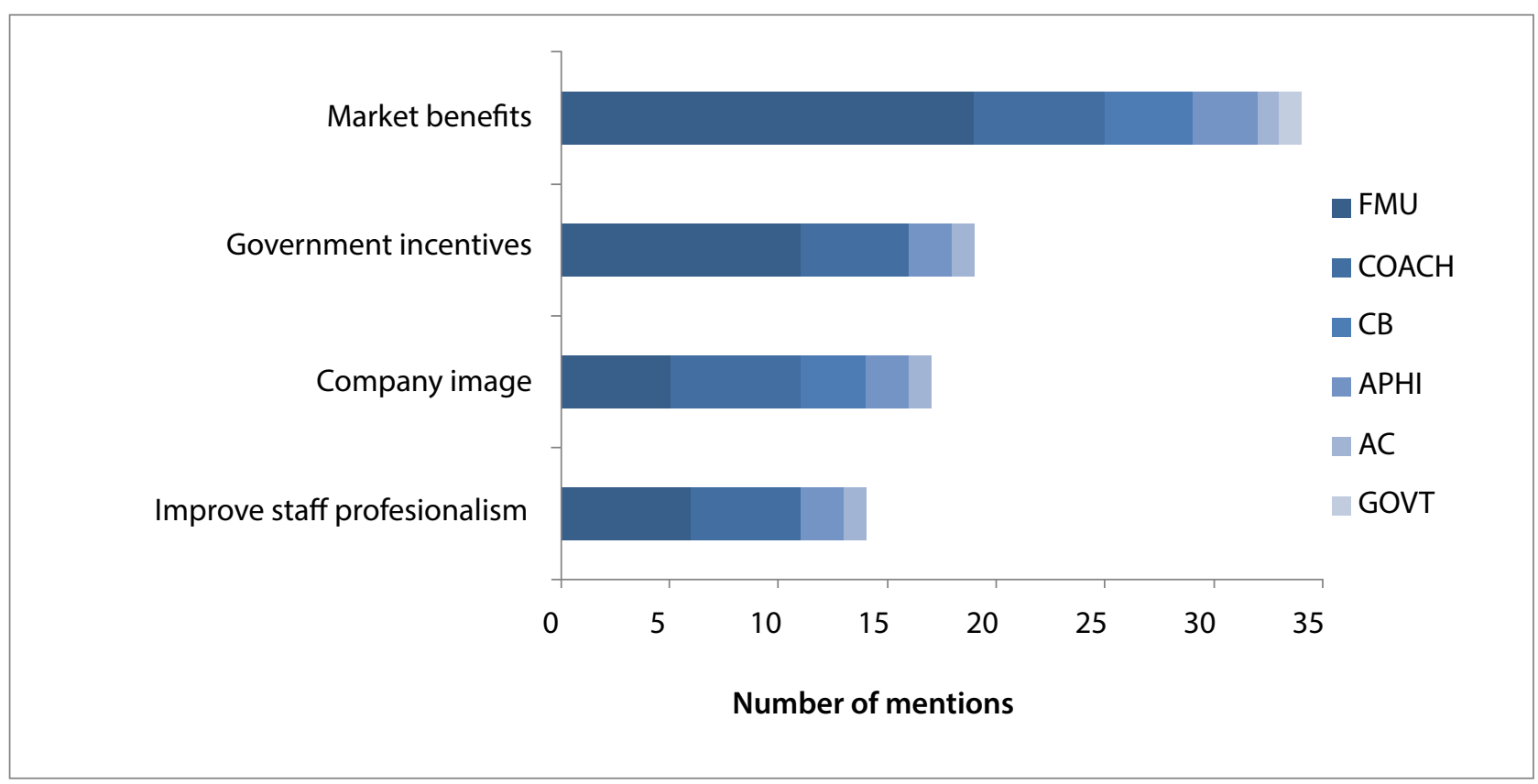

Figure 5.2. Dominant motivation for natural forest certification mentioned by stakeholders during semistructured interviews in Indonesia. ( $n=34$ respondents are allowed to mention more than one motivations). For abbreviations see Figure 5.1.

certified molding and flooring products of bangkirai (Shorea leavis) at high prices to niche markets in Europe. The overall dominance of market incentive as a motivation for certification was evident during the interviews (Figure 5.2). Different views were expressed by FMUs as evidenced in responses on their future FSC certification and contingent on whether these FMUs were certified at early or late periods. Late-certified FMUs stated clearly that they would drop FSC certificate if there were no financial benefits, particularly a premium price. While earlycertified FMUs did not condition their future FSC certificate to market benefits.

\subsubsection{Who made certification decisions in the FMUs and how were those decisions made?}

Decision-making processes within FMUs are shaped by the structure of corporate management. If the company is directly managed by owners, then all decisions, including those related to certification, are typically made by them. For concessions for which the owners do not directly manage the FMU (e.g. FMUs under the Alas Kusuma or Dwima Jaya Groups), decisions are made by the forest industry group (i.e., parent company) to which the FMU belongs. Non-integrated FMUs are mostly small and managed directly by their owners. Of the 21 FMUs sampled, either individually or represented by their parent company group, certification decisions were reportedly made by the forest industry division in 8 cases, by FMU owners in 11 cases, and by the CEOs of the remaining 2 FMUs. It is nevertheless important to note that in all decision-making contexts, technical directors had substantial influence because they are recognized as credible information sources by decision-makers at higher administrative levels. In a few cases, information provided by log buyers reportedly drove the FMUs to pursue certification. For state-owned operations, decisions related to certification were made by FMU CEOs although financial resources to cover the costs of certification were provided by "logging contractors" to harvest timber in the concessions.

For forest companies that controlled more than one FMU, decisions about certification are made gradually and start with the FMU having the highest potential economic benefits (often the largest FMU in the group) and highest likelihood of successful certification. Two of the company groups interviewed do not plan to certify all FMUs under their control, due to economic concerns. For example, one FMU from one group reportedly will not be promoted for certification because it yields little timber and suffers massive social conflicts mostly related to shifting cultivation. 


\subsubsection{Expected benefits and major costs of certification}

The price premium for certified forest products was an expected benefit mentioned by all stakeholders that opted for certification. Some certified FMU managers and certification coaches specifically mentioned the existence of price benefits for bangkirai (Shorea leavis) and merbau (Intsia spp.) flooring in European and Australian markets. These certification coaches also mentioned that during some periods certified FMUs received price benefits for selling bangkirai logs to forest industries in Java, but those benefits disappeared with the global financial crisis of 2008. In addition to the premium price, FMUs certified during the early years also expected enhancement of company reputation, professional improvement of their staff, and government incentives. This last-mentioned motivation was characteristic of FMUs in the process of the concession permit extension. Some other FMUs mentioned government incentives in the form of self-approval of the annual harvesting target. In total, government incentives were mentioned by 19 respondents as expected benefits (most frequently mentioned after price benefits). Other expected benefits (company reputation enhancement, improvement on the staff professionalism, and fulfilling loan conditions) were mostly mentioned by the certification coaches and certification bodies, with only a few mentions by FMUs.

The major cost of certification mentioned by all respondents was due to changes in forest management and/or logging operations. These requirements often included hiring new staff, staff training, adoption of RIL and infrastructure such as warehouses, and worker camp upgrades. All respondents were aware of these costs, because although TBI contributes up to US \$2 per ha towards certification, an equal amount needs to be covered by the FMUs (i.e., the costs are matched by TBI and the FMU; detailed in Ruslandi et al. 2014). One respondent mentioned that his FMU spent about US $\$ 200,000$ to get certified. Among the costs mentioned by many FMUs and certification coaches were high conservation value forest (HCVF) assessment, social impact assessment, and launching community development programs. It was surprising that audit costs were not considered as major by the majority of stakeholders. In many other studies, particularly in community forests, audits represent a big share of the total cost (e.g., Alemagi et al. 2011, Crow and Danks 2010, Hartsfield and Ostermeier 2003, Humphries and Kainer 2006). This difference is probably due to the fact that in Indonesia this cost is covered by external funding and because it is small relative to the operational costs of a large industrial FMU (see Ruslandi et al. 2014). Answers to questions related to perceived specific benefits and costs of certification were most complete from certification coaches and certification bodies. Only two certification coach representatives and one respondent from a certification body mentioned that certification benefits were related to the fulfillment of loan conditions.

\subsubsection{The biggest challenges for certification}

The requirement for changes in forest management and/or logging operations was mentioned both as the major cost of certification and the largest challenge. This perception reflects the required changes for a FMU from being a "logging company" (i.e., an exploiter of timber) to a "forest management company". Some respondents mentioned that although the company owner agreed to pursue certification, changing staff attitudes at all levels was not easy and did not happen quickly. In some cases, required changes faced resistance from logging crews to change well-established practices. Furthermore, given that the certification process takes years (Ruslandi et al. 2014), maintaining staff enthusiasm was reportedly challenging. Finally, the major costs of certification that were frequently mentioned included HCVF establishment and dealing with social issues. Overall it appears that, FMUs engaged in substantial social conflicts related to high population densities within and near the FMU, were less likely to seek certification. Strong commitment from all levels of management, socially skilled staff, and governmental support seem needed for such FMUs to opt for certification.

\subsection{Discussion}

Two important questions derive from the above findings about motivation for natural forest management certification. First, how do these motivations and drivers influence the outcomes 
of certification? - to the extent that they do, they should be considered in certification impact evaluations. Second, how might certification most effectively be promoted given the reported motivations and drivers? To address these questions, a historical analysis of the motivations and drivers towards certification and FMU characteristics related to certification decisions were conducted.

\subsubsection{Certification decisions as related to FMU characteristics and external contexts}

\section{Early years of certification (1996-2003)}

Efforts to promote sustainable forest management (SFM) in Indonesia have been underway for decades but ramped up in the mid-1990s. Pilot projects on SFM were conducted in a number of FMUs, with support from the Government of Indonesia and donor countries (e.g., France, UK, USA). At the same time, the association of Indonesian forest concessionaires (APHI) launched a program to prepare its members to meet the ITTO 2000 Target on SFM. To that end, some FMUs were selected for field testing of the APHI's standard for SFM. The FMUs selected were reportedly those with relatively good forest management practices, at least based on APHI's measures. During the same period, NGOs established the Lembaga Ekolabel Indonesia (LEI) certification system. Later in 2009, the MoF established a mandatory certification system (PHPL). One outcome of these processes is that some FMUs advanced towards SFM and became more knowledgeable about forest certification. It followed that these FMUs dominated natural forest certification in Indonesia, especially during the early period.

Interviews revealed that during the early years of certification in Indonesia (1996-2003) it was mostly the FMUs that had worked with NGOs and international forestry projects that pursued certification. This tendency is reasonable given that with only relatively small investments in further improvements in management, the five FMUs that became were first certified could access the potential benefits of certification including both price premiums and improved corporate reputations. Other than Diamond Raya, which produced high-quality products from ramin (Gonistylus bancanus) for European markets, the principal market for the other four first certified FMUs was Japan (for plywood). The benefits of FSC certification in Japanese markets are complicated, often relate more to market preferences than to price premiums, and are often indirect insofar as certification is taken by Japanese importers as an indication of reliability and good business practices.

It is clear that market benefits and to some extent non-market but related to economic motivators dominated during the first phase of certification in Indonesia. SFM programs supported by donor countries and APHI promoted adoption of certification. The FMUs that pursued certification during this period were well established (i.e., in existence since 1990 or before) and integrated with forest industries, had major markets in Japan and South Korea and benefited from participation in SFM research and demonstration projects.

\section{Later years of certification (2004-2014)}

A market emerged for saw timber and logs as China prepared for the Olympic Games in the early years of the new millennium. An emerging market for legally and illegally procured sawntimber and logs of merbau species (Intsia spp.) from Papua. It turned out, however, that some of this wood and wood products were re-exported from China to Europe, some of which were claimed as certified (TFT, pers. comm.). Investigations by international NGOs revealed that China was laundering illegally harvested merbau timber from Indonesia (EIA and Telapak 2005). As a response, starting in 2003-2004, some European and North American buyers (e.g., DLH and Armstrong, TFT's buyer members) tried to trace the origins of the timber and other forest products they were purchasing and established direct connection to the forest product producers in Indonesia (TFF, pers. comm).

During the same period, domestic political conditions in Indonesia were not conducive to good forest management nor adoption of certification, but instead favored illegal logging (Chapter 2, this volume). Log prices from illegal sources were cheaper than from legal logging operations (US \$30 compared to US $\$ 70 / 80$ per $\mathrm{m}^{3}$, respectively; APHI, pers. comm.). At the same time, global prices for the sorts of utility grade plywood exported from Indonesia also dropped sharply due to competition from poplar plywood from China and to some extent the rubber plywood from Malaysia. 
Partially as a result of competition with illegal timber, the needs of Indonesian forest industries matched the desires of European and North American buyers. One solution was to seek better prices through market differentiation. These joint interests of buyers and forest industries were served by forest-market linking programs, which gained momentum after starting in 2003/2004. Initially the focus was on flooring and garden furniture from bangkirai, a heavy and naturally rot-resistant hardwood, and also on decking from merbau.

Some organizations (TFF, TFT, WWF) actively promoted this program which attracted many FMUs, as it provided market access and price premiums. The condition for participation in the program was that the FMUs needed to follow a step-wise approach to certification (i.e., the FMU should agree on the action plan to achieve FSC certification over a specific period, normally up to five years). In exchange, FMUs would be provided with technical assistance at no cost. Further, FMUs interest in certification was not restricted to the best performers that were formally integrated with forest industries. In some cases, logging contractors and major log buyers took advantage of this program, by linking their FMU partners to the sponsoring organizations. A number of newly created FMUs also joined the program. It seems that in addition to the tactical opportunities offered, the desire to survive in the business dominated the reasons to opt for certification. Unfortunately, this program reached only FMUs with connections to buyers from within Europe or the USA as well as a few FMUs with links to certification institutions (i.e., certification coaches, certification bodies, and NGOs).

Starting in 2006-2007, domestic log prices recovered to those before massive illegal logging, more FMUs resumed timber harvests, and interest in certification grew. Since 2010, TBI has provided funding for certification, with several organizations assuming active roles as certification coaches. The TBI program boosted natural forest certification because (in addition to the technical assistance provided by the abovementioned market linking program) it provided financial assistance for certification audits and training. At the time of this writing, certification continues to grow in Indonesia yet contributes modestly to forest sustainability goals (only $5 \%$ in terms of number of FMUs and $8 \%$ in terms of area in forest concessions).
A fundamental issue related to medium and long-term management decisions made by FMU managers relates to their prospects to remain in operation. The new MoF requirement for permit extension that FMUs must pass the mandatory forest certification under its scheme (SVLK, PHPL) has helped some FMUs prepare for FSC certification. Yet, this study noted that the roles of LEI certification system and mandatory certification (SVLK and PHPL) in promoting FSC certification and sustainable forest management practice in Indonesia are marginal. LEI certification, in particular, seems to have a limited role because it is not recognized internationally nor nationally by the government of Indonesia. The $\mathrm{MoF}$ still requires mandatory certification (SVLK and PHPL) for the FMUs with either LEI or FSC certificates. Even though the standards for PHPL are much lower than for FSC certification, once an FMU undergoes mandatory certification it might be more prepared to undergo the more rigorous process that leads to FSC certification. Thus it is possible that to save money the FMUs might just comply with the mandatory certification and abandon the FSC scheme.

\subsubsection{Dominance of timber market dynamics and economic motivations for certification}

Representatives of most of FMUs and related forest industries stated that they will withdraw from certification if there are no financial benefits. They also pointed out that FMU managers with expressed interests in certification expect to receive financial benefits if they become certified. In that respect, this study confirms that the main motive for Indonesian FMUs to seek FSC certification is economic, particularly premium prices and improved market access. This finding is consistent with that of many other similar studies (e.g., Espinoza and Dockry 2014, Hartsfield and Ostermeier 2003, Humphries and Kainer 2006, Trishkin et al. 2014). In some cases, the costs of certification are compensated for by higher market prices; for example, products from community-based FMUs in Brazil obtained 40\% price premiums on the local log market in Acre (Humphries 2010). In reality, market benefits, particularly premium prices, are limited, product and market specific, and temporally dynamic. For example, certified timber products from Bolivia reportedly enjoyed $5-51 \%$ price premiums early in the 2000s (Nebel et al. 2005), but these 
disappeared later thus forcing some FMUs to drop their certificates (Espinoza and Dockry 2014). In Indonesia, the price premium on certified bankirai logs was $50 \%$ on the domestic market during 2006-2007. These logs were sold to unintegrated forest industries in Java, which in turn sold their final product to Europe (TFT 2007). Wood flooring products exported to Europe also gained premium prices of $10-15 \%$ during the same period. Unfortunately, these premiums disappeared with the global financial crisis in 2008.

In Indonesia, lack of large and consistent market incentives for certification is being counterbalanced by the availability of financial and technical support for getting and remaining certified. Although support from TBI and certification coaches is available, FMU representatives still doubt about the financial benefits of certification. It remains to be seen whether this hesitation is most pronounced among the poorly-run FMUs for which the costs of compliance with FSC requirements would be very high. The claim made here that the best-run FMUs were the first to seek certification also requires verification. Nevertheless, the challenge remains to attract more FMUs to pursue certification, and thereby improve their management practices. For this to happen in any substantial way, the economic benefits from certified forest management need to be augmented. Environmental service payments, including carbon payments for certified forest management, could promote certification for tropical forest in Indonesia and elsewhere. As discussed earlier, securing economic benefits from voluntary certification is critical due to direct competition with timber legality verification and mandatory forest certification (SVLK and PHPL). SVLK and PHPL could be synergistic to voluntary certification or become a reason for FSC certification downfall in Indonesia. One source of synergy is that FMUs that currently have little knowledge about certification will learn as they prepare themselves for the MoF's mandatory certification. These FMUs might seek assistance from the certification coaches and then might prepare themselves for both mandatory and voluntary certification, at least if the economic benefits are evident.

This study emphasized gathering perspectives with stakeholders already exposed and involved with certification at one point in time. In that sense, the results are representative and provide a reasonable portray of dominant factors that motivate becoming and remaining engaged in FSC certification. Yet, they do not represent the large number of FMUs that have never been involved in certification. Interviews with this category of FMUs should be conducted in the future, but the questions asked would need to be modified.

Surprisingly, representatives of four out of the six certified FMUs included in this study reported that they do not plan to drop their FSC certificates even if there are no financial benefits. This is different from the results in USA and Brazil where FMUs are reportedly unlikely to recertify their forests if the economic benefits are limited (Araujo et al. 2009, Faggi et al. 2014, Overdevest and Rickenbach 2006).

\subsubsection{Major cost and the biggest challenge of certification}

The passage from timber exploitation to sustainable or at least responsible forest management remains the biggest fundamental challenge faced by natural forest certification in Indonesia. This route often involves short-term costs but long-term benefits. For some poorly-run FMUs, even if the major direct costs of certification (e.g., audits and HCVF surveys) are paid by external agencies, there might still be financial reasons not to seek certification. If the MoF's mandatory certification programs (SVLK and PHPL) require that FMUs follow the established rules that govern management, then even the poorly performing FMUs will be forced to start to make the transition from exploitation to management. This transition will be facilitated if the financial benefits of certification are real, large, and generally accessible. It would also help if the certification process be streamlined and simplified; some FMUs reported that money for certification was not the problem, but the cumbersome process was off-putting.

\subsection{Conclusions}

The observed temporal variation in sources of motivation for natural forest certification in Indonesia can be described in terms of an early (1996-2003) and a later period (2004-2014). This grouping also relates to FMU characteristics. FMU age, period of forest certification engagement, market orientation, forest industry integration, long-term business strategy, and previous involvement in the improved forest management research and demonstration projects seem to shape 
the specific perceived forest certification drivers and motivations. Forest certification processes are influenced by corporate structures, with owners and forest industry divisions the most common deciders of whether or not to opt for certification.

Perceived financial benefits remain a major motivation for certification whereas the major impediment is the high costs of meeting certification standards, such as HCVF demarcation and surveys, social programs, and the hiring and training of staff. The biggest challenges are therefore economic (high costs and limited economic incentives) and the need for operational adjustments for production. These modifications of forestry practices include both environmental and social aspects that together contribute to operational costs and technical complexity. If forest certification is to expand in the natural tropical forests of Indonesia, then economic incentives should be enhanced with both real market incentives and continued financial and technical subsidies.

\subsection{References}

Alemagi D, Hajjar R, David S and Kozak RA. 2011. Benefits and barriers to certification of community-based forest operations in Cameroon: An exploratory assessment. SmallScale Forestry, 11(4), 417-433. doi:10.1007/ s11842-011-9192-9

Araujo M, Kant S, and Couto L. 2009. Why Brazilian companies are certifying their forests? Forest Policy and Economics, 11(8), 579-585. doi:10.1016/j.forpol.2009.07.008

Auld G Cashore B and Newsom D. 2003. Perspectives on forest certification: a survey examining differences among the US forest sectors' views of their forest certification alternatives. In: Teeter, L., Cashore, B., Zhang, D. eds. Forest policy for private forestry: global and regional challenges. CABI Publishing, New York, pp. 271-282.

Blackman A and Rivera J. 2011. Producerlevel benefits of sustainability certification. Conservation Biology: The Journal of the Society for Conservation Biology, 25(6), 1176-85. doi:10.1111/j.15231739.2011.01774.x

Chen J, Innes JL and Kozak RA. 2011. An exploratory assessment of the attitudes of Chinese wood products manufacturers towards forest certification. Journal of
Environmental Management, 92(11), 298492. doi:10.1016/j.jenvman.2011.07.012

Crow $S$ and Danks C. 2010. Why Certify? Motivations, outcomes and the importance of facilitating organizations in certification of community-based forestry initiatives. SmallScale Forestry, 9(2), 195-211. doi:10.1007/ s11842-010-9110-6

Edwards DP, Tobias JA, Sheil D, Meijaard E and Laurance WF. 2014. Maintaining ecosystem function and services in logged tropical forests. Trends in Ecology \& Evolution, 1-10. doi:10.1016/j.tree.2014.07.003

Espinoza O and Dockry MJ 2014. Forest Certification in Bolivia: A Status Report and Analysis of Stakeholder Perspectives. Forest Products Journal, 64(3-4), 80-89. doi:10.13073/FPJ-D-13-00086

Faggi AM, Zuleta GA and Homberg M. 2014. Motivations for implementing voluntary environmental actions in Argentine forest companies. Land Use Policy. doi:10.1016/j. landusepol.2014.04.011

Ferraro PJ. 2009. Counterfactual Thinking and Impact Evaluation in Environmental Policy, (122), 75-84. doi:10.1002

[FSC] Forest Stewardship Council. 2014. Public Certificate Search. http://info.fsc. org/certificate.php\#result. Accessed on 10 June 2014.

Gaveau D, Curran L, Paoli G, Carlson K, Wells P, Besse-Rimba A, Ratnasari D and LeaderWilliams N. 2012. Examining protected area effectiveness in Sumatra: importance of regulations governing unprotected lands. Conservation Letters, 5(2), 142-148.

Gaveau D, Kshatriya M, Sheil D, Sloan S, Molidena E, Wijaya A, Wich S, Ancrenaz M, Hansen M, Broich M, Guariguata MR, Pacheco P, Potapov P, Turubanova S and Meijaard E. 2013. Reconciling Forest Conservation and Logging in Indonesian Borneo. Plos One, 8(8), pp. e69887.

Gaveau D, Sloan S, Molidena E, Yaen H, Sheil D, Abram N, Ancrenaz M, Nasi R, Quinones M, Wielaard N and Meijaard E. 2014. Four Decades of Forest Persistence, Clearance and Logging on Borneo. Plos One, 9(7), pp. e101654.

Griscom B, Ellis P and Putz FE. 2014. Carbon emissions performance of commercial logging in East Kalimantan, Indonesia. Global Change Biology, 20(3), 923-37. doi:10.1111/ gcb. 12386 
Hartsfield A and Ostermeier D. 2003. The View from FSC-Certified Land Managers, Journal of Forestry 101(8): 23 - 36.

Humphries SS. 2010. Community-based forest enterprises in brazil and mexico : timber production and commercialization models , market engagement, and financial viability. Phd dissertation. University of Florida.

Humphries SS and Kainer KA. 2006. Local perceptions of forest certification for community-based enterprises. Forest Ecology and Management, 235(1-3), 30-43. doi:10.1016/j.foreco.2006.07.027

[LEI] Lembaga Ekolabel Indonesia. 2014. FMU and Manufacture LEI Certified Updated : July 2013. http://www.lei.or.id/files/FMU\%20 \&\%20Manufacture\%20certified \%20LEI_ July\%202013.pdf. Accessed on 10 June 2014.

[MoF] Ministry of Forestry. 2008. Eksekutif Data Strategis Kehutanan 2008. Badan Planologi Kehutanan. Depertemen Kehutanan. Jakarta.

[MoF] Ministry of Forestry. 2009.Peraturan Menteri Kehutanan Nomor: P11/MenhutII/2009 tentang sistem silvikultur dalam areal ijin usaha pemanfaatan hasil hutan kayu pada hutan produksi. Kementrian Kehutanan. Jakarta.

[MoF] Ministry of Forestry. 2013. Basis Data Spasial Kehutanan Tahun 2013. Direktorat Jenderal Planologi Kehutanan. Kementerian Kehutanan. Jakarta.

Muhtaman DR and Prasetyo FA. 2006. Forest certification in Indonesia. In: Cashore, B., Gale, F., Meidinger, E. and Newsom, D. eds. Confronting sustainability: Forest certification in developing and transitioning countries. Yale F\&ES Publication Series, Report Number 8.

Nebel G, Quevedo L, Bredahl Jacobsen J, and Helles F. 2005. Development and economic significance of forest certification: the case of FSC in Bolivia. Forest Policy and Economics, 7, 175-186. doi:10.1016/S13899341(03)00030-3

Obidzinski K, Dermawan A, Andrianto A and Komarudin H. 2014. Verifikasi legalitas kayu di Indonesia dan usaha kehutanan skala kecil Pelajaran dan opsi kebijakan,CIFOR Brief Info (70):1-8.
Overdevest C and Rickenbach MG. 2006. Forest certification and institutional governance: An empirical study of forest stewardship council certificate holders in the United States. Forest Policy and Economics, 9, 93-102. doi:10.1016/j.forpol.2005.03.014

Owari T, Juslin H, Rummukainen A and Yoshimura T. 2006. Strategies, functions and benefits of forest certification in wood products marketing: Perspectives of Finnish suppliers. Forest Policy and Economics, 9(4), 380-391. doi:10.1016/j. forpol.2005.10.005

Romero C, Putz FE, Guariguata M, Sills E and Cerutti PO. 2013. A review of current knowledge about the impacts of forest management certification and a proposed framework for its formal evaluation. CIFOR Occasional Paper, Bogor, Indonesia.

Ruslandi, Klassen A, Romero C and Putz FE. 2014. Forest Stewardship Council Certification of Natural Forest Management in Indonesia: Required Improvements, Costs, Incentives, and Barriers. InIUFROWFSE book "Forests under pressure: Local responses to global issues".

Sunderlin WD and Resosudarmo IAP. 1997. Laju dan Penyebab Deforestasi di Indonesia: Penelaahan Kerancuan dan Penyelesaiannya. Occasional paper no. 9. Center for International Forestry Research. Bogor, Indonesia.

The Borneo Initiative (TBI). 2014. http:// www.theborneoinitiative.org/about-theborneo-initiative/about-us. Accessed on 10 June 2014.

Trishkin M, Lopatin E and Karjalainen T. 2014. Assessment of motivation and attitudes of forest industry companies toward forest certification in northwestern Russia. Scandinavian Journal of Forest Research, (August 2014), 1-11. doi:10.1080/0282758 1.2014 .896938

Ward DT. 2013. Why should we certify our forests? Factors that influence the adoption and maintenance o forest certification in Quintana Roo, Mexico. PhD Dissertation. University of Florida. 
Appendix 1. Questionnaire for FSC certification self-selection of natural forest concessions in Indonesia

\begin{tabular}{|l|l|}
\hline Concession/Institution: & \\
\hline Interviewee: & \\
\hline Position: & \\
\hline Date: & \\
\hline Interviewer: & \\
\hline
\end{tabular}

1. Historical factors/conditions influenced SFM/certification (1998 - 2013)

2. Who/what level/division in the concession/parent company made decisions about certification and what were the key information flows?

3. Motivation for certification

Concessions that are not interested in certification were also asked for reasons:

4. Expected benefits of certification

Market:

Non market:

5. Perceived costs for certification (what are the major costs)

6. The biggest challenges for certification

7. Factors that influenced concessions to pursue certification

8. Other comments and notes: 


\title{
Conclusions
}

\author{
Claudia Romero, Francis E Putz, Erin O Sills, Manuel R Guariguata, \\ Paolo O Cerutti and Guillaume Lescuyer
}

The chapters in this volume provide much of the information needed for the design of an empirical evaluation of selected outcomes of FSC certification in Indonesia. The political economy analysis reveals the linkages among the several factors at different levels that shaped power relations among social actors (i.e., government; timber sector; consumers and market dynamics; environmental groups) with stakes in forests right allocation and conservation, forest management decisions, and ultimately, FSC certification. This analysis reveals how power dynamics around the valuable timber resources and subsequent actions shaped changes in regulatory frameworks (e.g., incentives, log-export bans, oil palm moratorium) and other factors (e.g., increased illegality), and how in turn these frameworks were influenced by a range of factors and actors (e.g., economic crisis, Greenpeace, Global Forest Watch).

Small-scale commercial logging in Indonesian natural forests, which started early in the 1950s, gave rise to large-scale operations in the 1970s. One noteworthy process, in 1983, was the consolidation of the forest estate and designation of uses for each province, a process held without due participation of local people. This legal framework allowed governmental seizure of the forests and facilitated their commercial exploitation and conversion. About $63 \%$ of the area was designated for timber exploitation by the MoF. Later reclassification processes carried out by other state agencies started just when discussions for FSC certification were taking shape worldwide. Unfortunately, these planning efforts were inconsistent with actual land uses and resulted in political struggles between the involved agencies and between the central and local governments after the decentralization process in 1999. To date, overlapping jurisdictions and competing land uses affect much of the country's forest state. The Indonesian High Court's 2012 ruling on the matter of land allocation intends to force the government to finalize the forest delineation process, this time with more participation. Such rulings in the past have had only minor impacts, such as when sustainable forest management was made mandatory in 2002, and when the government imposed a two-year moratorium to new timber concessions in 2011.

The Asian economic crisis (1997-1998) and the fall of Soeharto were followed by further decentralization regulations (1999), which conferred decision-making powers on local governments. Another major change at that point included the break-up of large concessions. Still, land allocation decisions continued to be made in a politically conflicted environment across all governance levels. This period also saw the collapse of well-established forest industries closely related to the Soeharto regime, whose owners repositioned themselves to maintain control of valuable timber resources. With all the inconsistent and conflicting regulations and limited enforcement, rampant and profitable illegal logging peaked in 2001.

Abundance of illegal timber in the market decreased prices and led to further reductions in timber stocks, which resulted in the closure of several logging concessions and processing facilities. But this period also saw the emergence of new efforts to promote responsible management. In particular, the international NGOs The Nature Conservancy (TNC) and World Wildlife Fund for Nature (WWF) developed the Alliance to Promote Certification and Combat Illegal Logging. This initiative included financial support for certification, often through the transfer of funds to other organizations to do necessary training (e.g., Smartwood and the Tropical Forest Foundation) and facilitation of market linkages, particularly with Japan and China as main outlets for Indonesian timber. Another initiative was the WWF-based Global Forest Trade Network (GFTN), which established a step-wise approach toward certification (i.e., company committed to a 5-year plan) including facilitation of market 
access to the USA and the EU. The appearance of new actors with goals of forest loss and illegality reduction through proper management resulted in institutional efforts, both within and outside the country, with clear missions to promote the adoption of sustainable and legallyverified management.

LEI, the national certification system, emerged almost simultaneously with FSC-certification efforts in Indonesia. After a short period of parallel and often contentious efforts, these two schemes entered a joint certification program (JCP) in 2000. A year later, Diamond Raya Timber was certified under the JCP scheme, with auditing services by SGS. But the short-lived period of collaboration, which saw at its peak with 5 more concessions joining JCP, ended in 2005 when the partnership dissolved. The current mandatory certification schemes in the country are SVLK and PHPL which are competing with FSC and other voluntary certification schemes (i.e., the 2011 creation of IFCC-KSKI, which is endorsed by PEFC). Explicit measures on legality verification were initiated in 2001, but the establishment of formal VPA agreements under the FLEGT umbrella did not formally happen until Indonesia signed it in 2009 . So far, $-50 \%$ of natural forests and plantations are under the legality verification scheme.

The governmental agents and institutions relevant to the forest sector have been relatively constant through time. On the non-governmental side, in contrast, activities designed to promote responsible forest management were carried out by a range of new and always shifting set of actors. Early on, ITTO supported actions towards forest fires prevention and management (1982) and FAO prepared a synopsis of forest management perspectives in the country (early 90s). Later on (1996), improved forest management training activities started through international assistance (e.g., DflD, EU, USAID, and GTZ later in 2000) and the timber association APHI. Diamond Raya was one of the companies that participated in these activities.

In 2000, TFF ramped up its capacity-building mission and helped strengthen training on RIL practices. With the training provided by TFF, several concessions entered into the certification continuum. The main institutions involved in certification during that period were the certifying bodies, particularly RA and SGS. But it was not until 2010 with the beginning of activities by TBI that explicit support-both financial and technical— to adopt certification allowed several other companies to join the scheme.

The above is the dynamic contextual background that influenced the decisions made by concession managers. As recognized by several social actors of a range of sectors (i.e., companies at different stages along the certification continuum, certification-supporting institutions, and certifying bodies) interviewed as per the factors that facilitated and barred certification, market-linking programs shows prominently. The elements that facilitated access of companies to these programs remain somewhat unclear, but a couple of insights were gained through interviews. It seems as though companies that were established in 1990 or before which had integrated operations with markets in Japan and South Korea, were the ones that most benefitted from certificationsupport programs. At later stages, programs favored companies that were willing to commit to certification and others that already had market linkages with consumer countries.

Indonesian logging companies are heterogeneous in traits that influence management decisions, including those pertaining to certification. The selection bias caused by companies deciding for certification at different times remains a challenge for an empirical evaluation design. What is clear is that the counterfactual group needs to be composed of companies that never entered the certification continuum (i.e., have not participated in training activities or had pre-assessment visits, and so on). Factors that were associated with some of these decisions relate to company characteristics, in particular, area and percent of production forest, age of the company, vertical integration, principal market outlet, and local human population density. On one end there are more recently-established companies that are not vertically integrated, that target mostly national markets, and, for the most part, have not engaged with certification. Those FMUs of this sort that made moves toward FSC were supported by TFF and TBI. At the other end of this complex continuum are companies with contrasting characteristics, including more engagement in certification. 
The knowledge gained through all the studies in this volume may be used to strategically decide on key certification outcomes to be empirically examined and on how to construct the counterfactual group. The impact evaluation questions will emerge from deliberative processes to be started and developed in an eventual next phase. To facilitate these discussions a broad range of stakeholders will have to be convened in order to assess how the evaluation can include broad concerns about the added value of FSC certification, as well as assess changes in certification's impacts through time. These stakeholders include NGOs, government representatives at different levels, the private sector, community associations, and individuals.
This volume highlights the opportunities and constraints that those responsible for managing FMUs have experienced in their efforts to improve their practices. That not all FMUs were either able to take advantage of new available programs and funding, or were otherwise unable to overcome barriers towards adoption of FSC certification demonstrates the heterogeneity of preferences and characteristics of the timber companies. Future work on the impact evaluation front entails the formulation of a theory-of-change to guide the evaluation strategy, the specification of assumptions, and the definition and testing of hypotheses for key selected outcomes to make visible the range of impacts of FSC certification. 

CIFOR Occasional Papers contain research results that are significant to tropical forest issues. This content has been peer reviewed internally and externally.

Management decisions on appropriate practices and policies regarding tropical forests often need to be made in spite of innumerable uncertainties and complexities. Among the uncertainties are the lack of formalization of lessons learned regarding the impacts of previous programs and projects. Beyond the challenges of generating the proper information on these impacts, there are other difficulties that relate with how to socialize the information and knowledge gained so that change is transformational and enduring. The main complexities lie in understanding the interactions of social-ecological systems at different scales and how they varied through time in response to policy and other processes. This volume is part of a broad research effort to develop an independent evaluation of certification impacts with stakeholder input, which focuses on FSC certification of natural tropical forests. More specifically, the evaluation program aims at building the evidence base of the empirical biophysical, social, economic, and policy effects that FSC certification of natural forest has had in Indonesia as well as in other tropical countries. The contents of this volume highlight the opportunities and constraints that those responsible for managing natural forests for timber production have experienced in their efforts to improve their practices. As such, the goal of the studies in this volume is to serve as the foundation to design an impact evaluation framework of the impacts of FSC certification of natural forests in a participatory manner with interested parties, from institutions and organizations, to communities and individuals.

\begin{tabular}{|c|c|c|}
\hline CGIAR & $\begin{array}{l}\text { RESEARCH } \\
\text { PROGRAM ON } \\
\text { Forests, Trees and } \\
\text { Agroforestry }\end{array}$ & $\begin{array}{l}\text { This research was carried out by CIFOR as part of the CGIAR Research Program on Forests, Trees } \\
\text { and Agroforestry (CRP-FTA). This collaborative program aims to enhance the management and } \\
\text { use of forests, agroforestry and tree genetic resources across the landscape from forests to farms. } \\
\text { CIFOR leads CRP-FTA in partnership with Bioversity International, CATIE, CIRAD, the International } \\
\text { Center for Tropical Agriculture and the World Agroforestry Centre. }\end{array}$ \\
\hline
\end{tabular}

cifor.org

blog.cifor.org
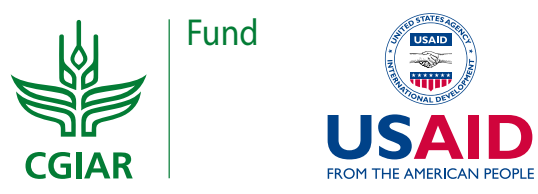

CIFOR advances human well-being, environmental conservation and equity by conducting research to help shape policies and practices that affect forests in developing countries. CIFOR is a member of the CGIAR Consortium. Our headquarters are in Bogor, Indonesia, with offices in Asia, Africa and Latin America. 